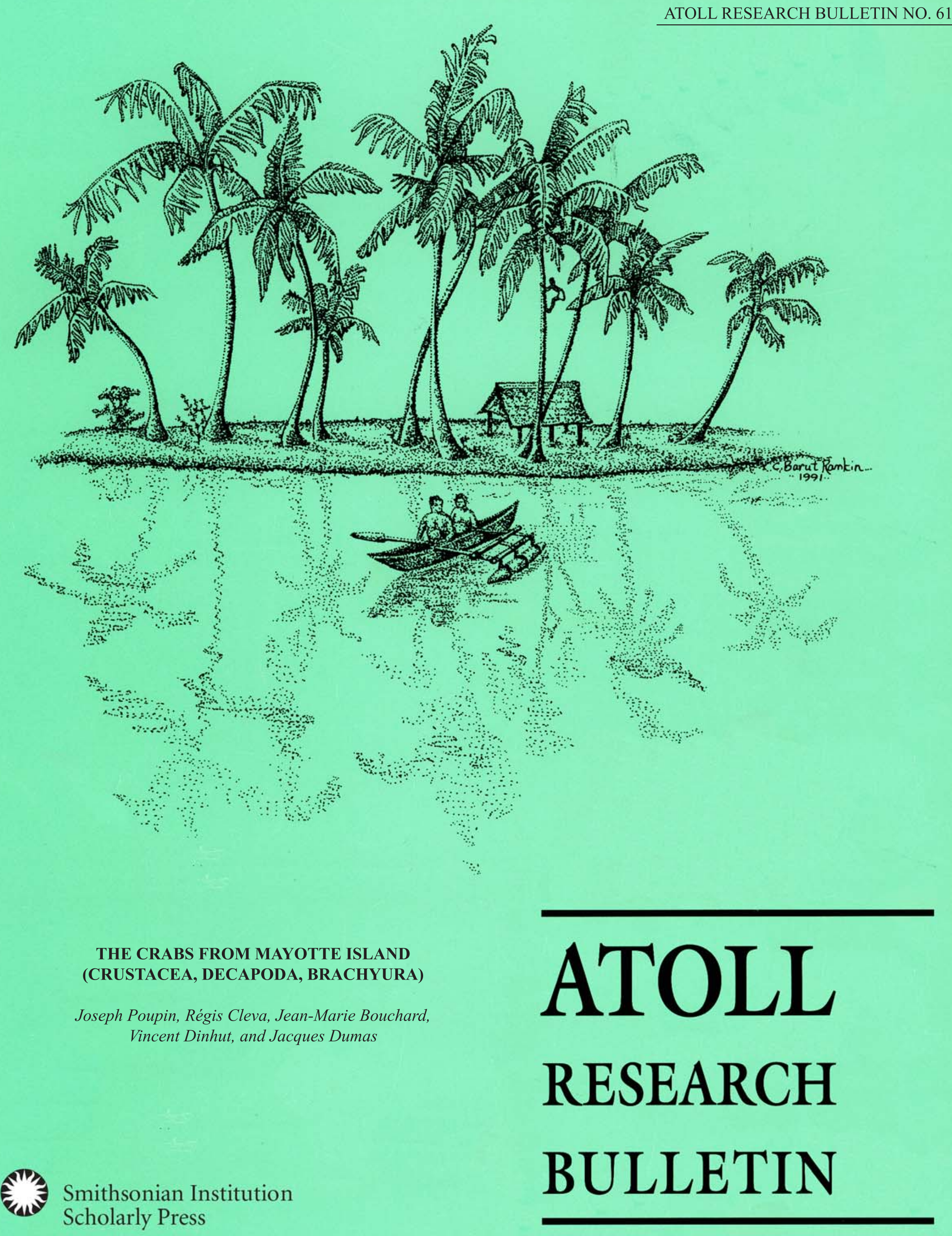




\section{THE CRABS FROM MAYOTTE ISLAND (CRUSTACEA, DECAPODA, BRACHYURA)}

Joseph Poupin, Régis Cleva, Jean-Marie Bouchard,

Vincent Dinhut, and Jacques Dumas

Atoll Research Bulletin No. 617 • 1 May 2018

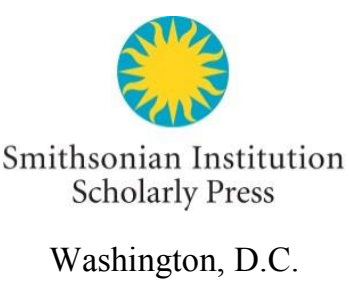


All statements made in papers published in the Atoll Research Bulletin are the sole responsibility of the authors and do not necessarily represent the views of the Smithsonian Institution or of the editors of the bulletin. Articles submitted for publication in the Atoll Research Bulletin should be original papers and must be made available by authors for open access publication. Manuscripts should be consistent with the "Author Formatting Guidelines for Publication in the Atoll Research Bulletin." All submissions to the bulletin are peer reviewed and, after revision, are evaluated prior to acceptance and publication through the publisher's open access portal, Open SI (http://opensi.si.edu).

\section{Published by SMITHSONIAN INSTITUTION SCHOLARLY PRESS}

P.O. Box 37012, MRC 957

Washington, D.C. 20013-7012

https://scholarlypress.si.edu/

The rights to all text and images in this publication are owned either by the contributing authors or by third parties. Fair use of materials is permitted for personal, educational, or noncommercial purposes. Users must cite author and source of content, must not alter or modify the content, and must comply with all other terms or restrictions that may be applicable. Users are responsible for securing permission from a rights holder for any other use.

ISSN: 0077-5630 (online) 


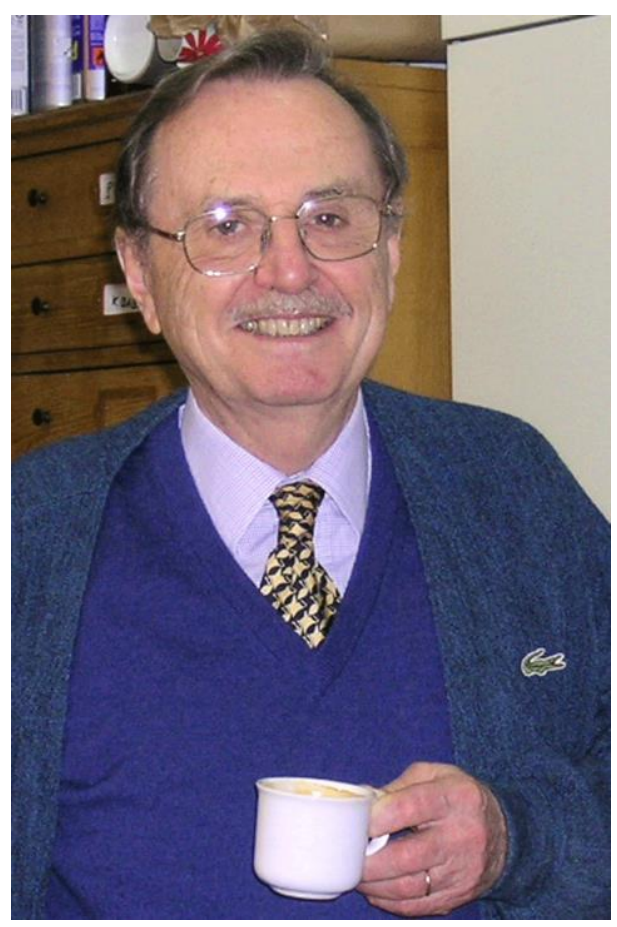

This work is dedicated to our friend Alain Crosnier, great contributor for crab sampling in Mayotte region between 1958-1971 and author of several important taxonomic contributions in the region. Photograph February 2006 courtesy of J. -F Dejouannet (photographer unknown) during a coffee break in Paris Museum. 



\section{CONTENTS}

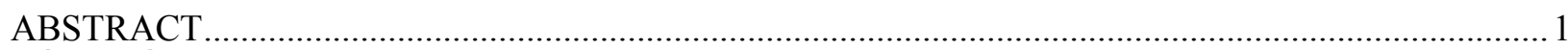

RÉSUMÉ

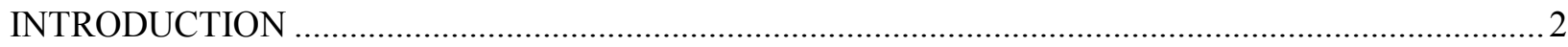

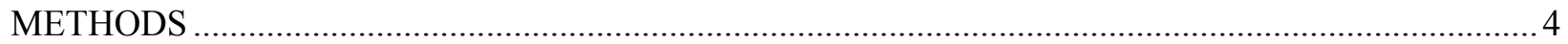

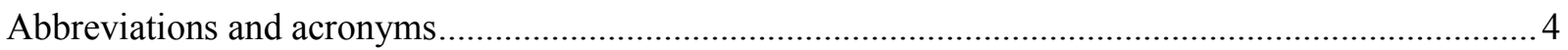

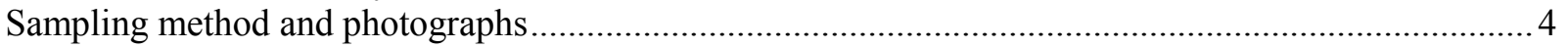

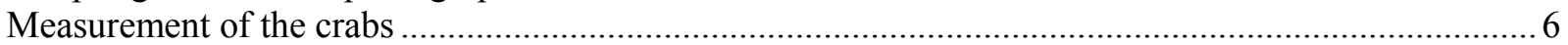

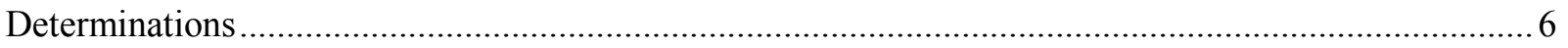

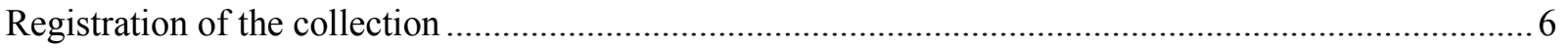

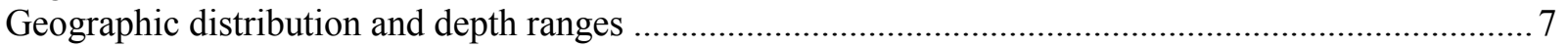

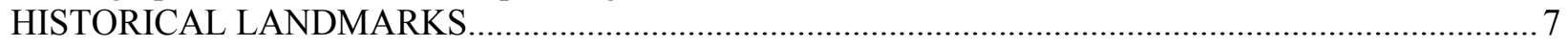

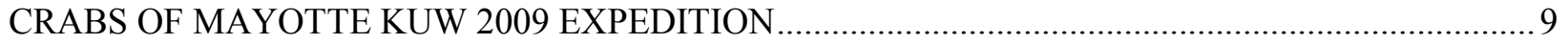

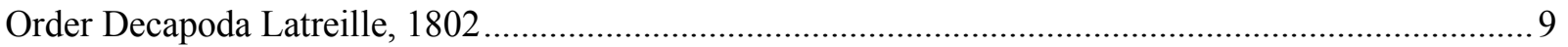

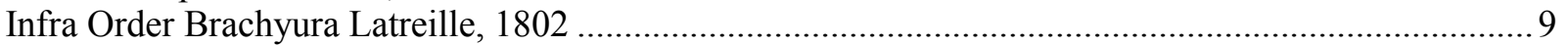

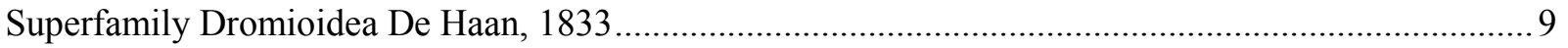

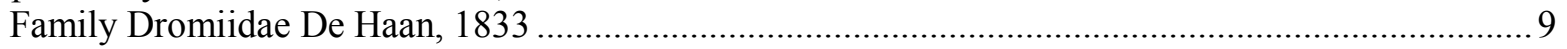

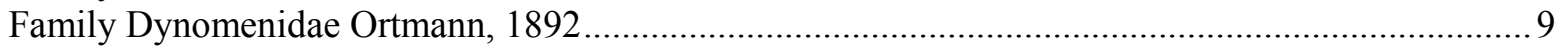

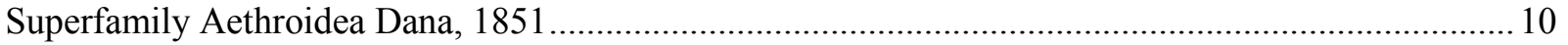

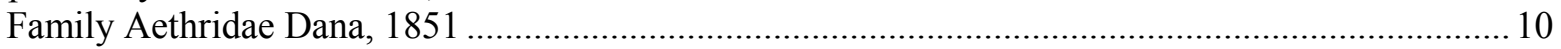

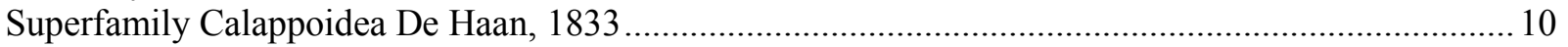

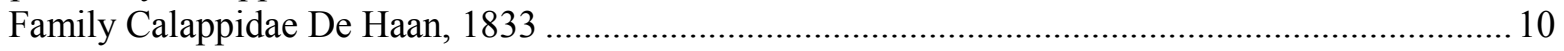

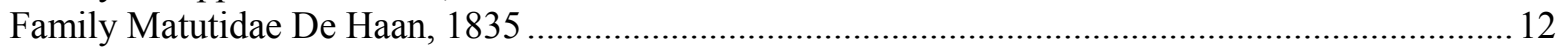

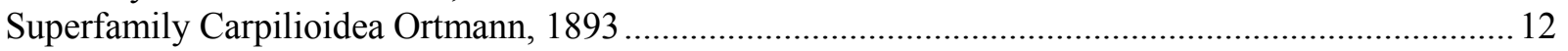

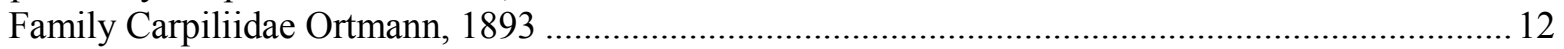

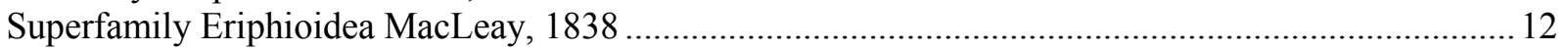

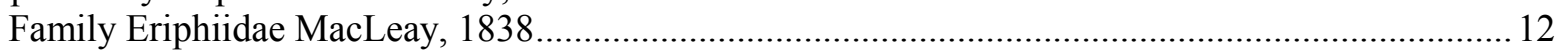

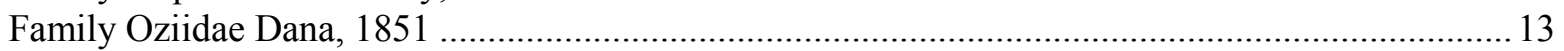

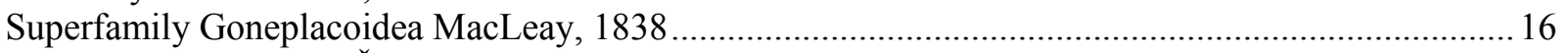

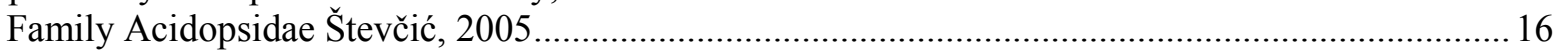

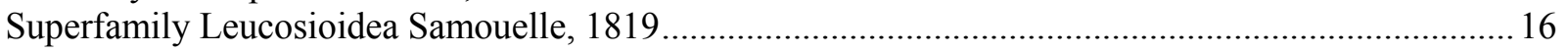

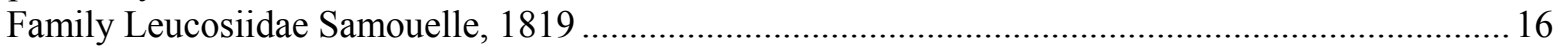

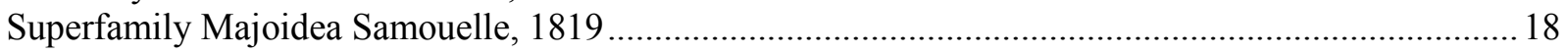

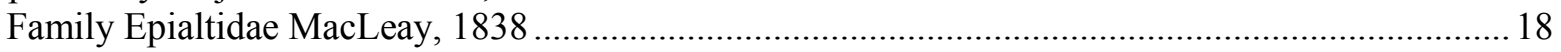

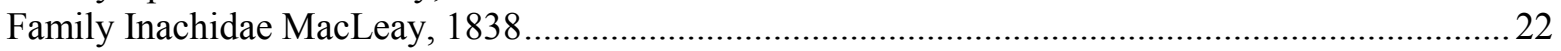

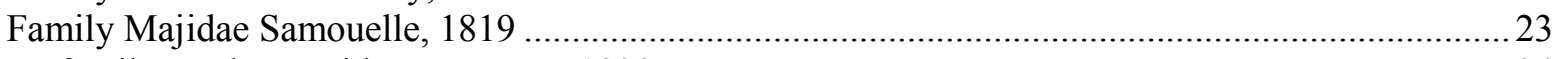

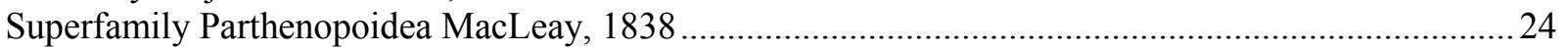

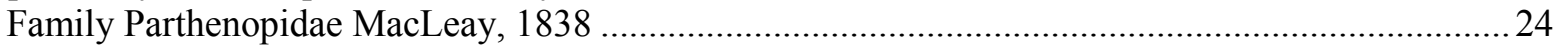

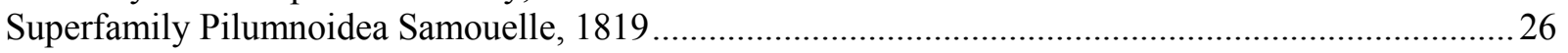

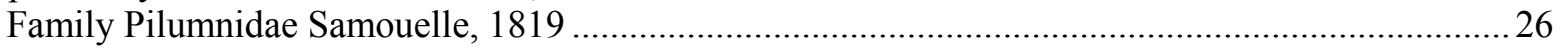

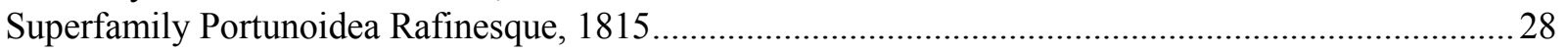

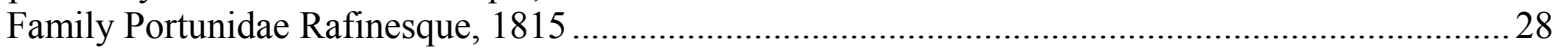

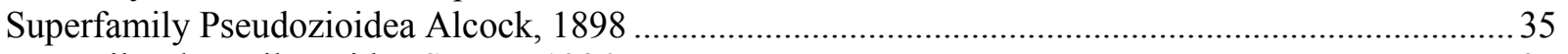

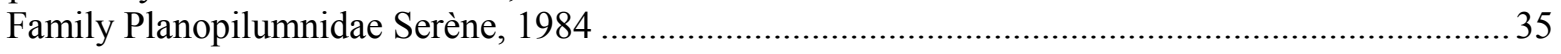

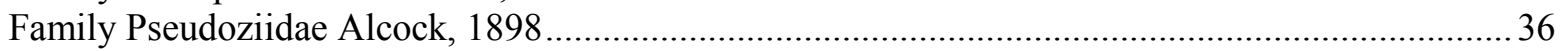

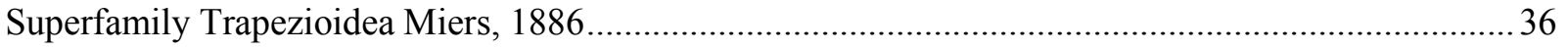

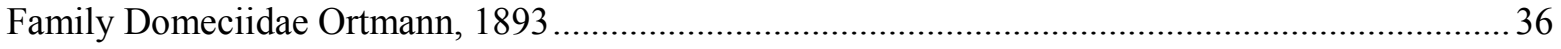

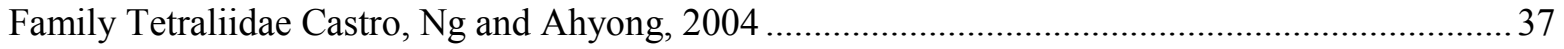

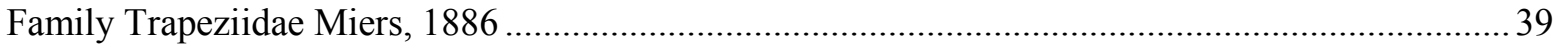

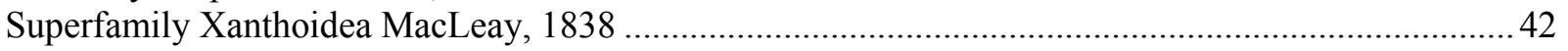




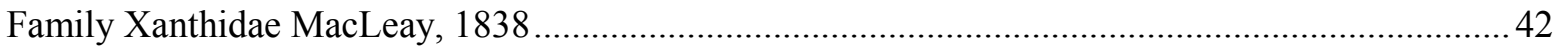

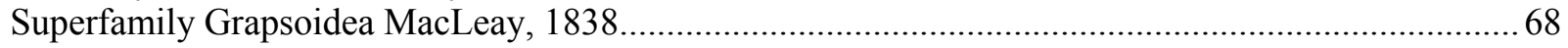

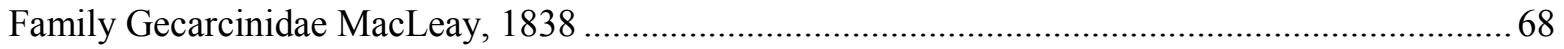

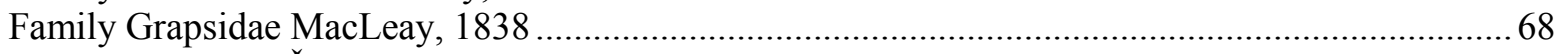

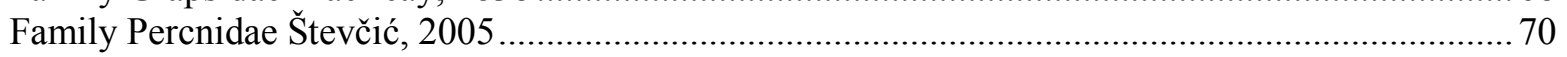

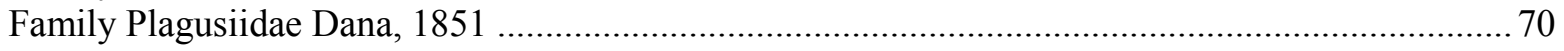

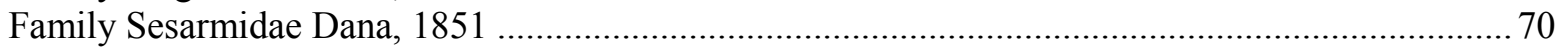

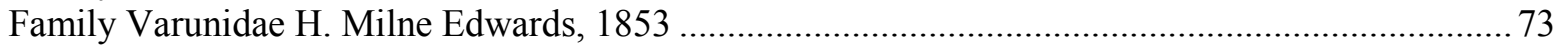

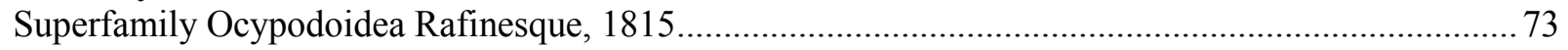

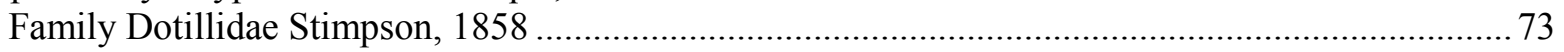

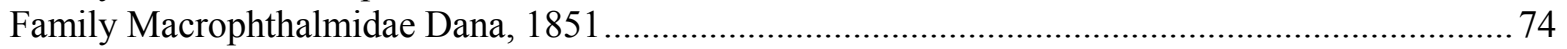

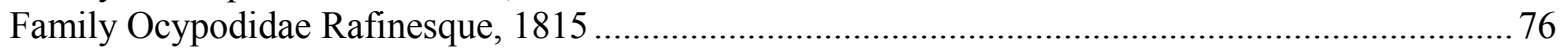

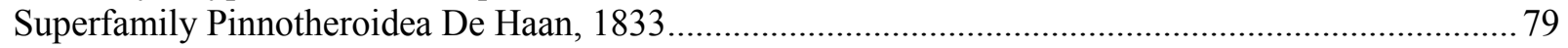

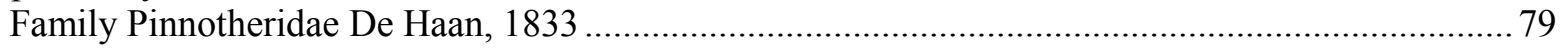

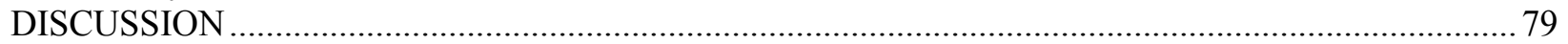

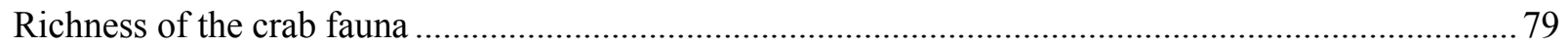

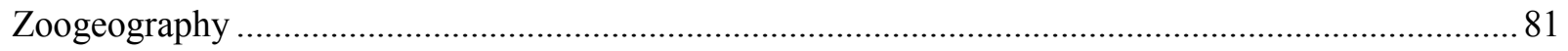

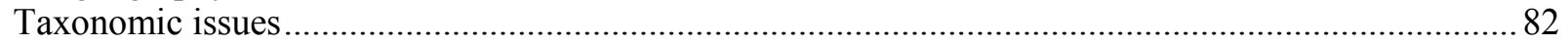

Ongoing studies on deep water collections in the region (MIRIKY 2009, BIOMAGLO 2017) ...........82

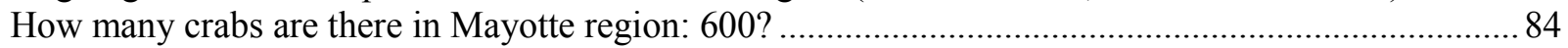

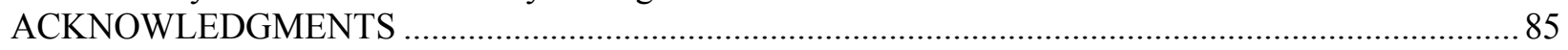

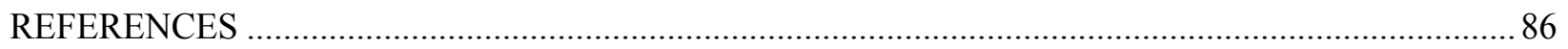

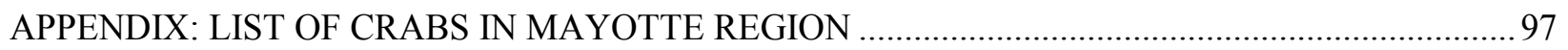




\title{
THE CRABS FROM MAYOTTE ISLAND (CRUSTACEA, DECAPODA, BRACHYURA)
}

\author{
JOSEPH POUPIN ${ }^{1}$, REGIS CLEVA ${ }^{2}$, \\ JEAN-MARIE BOUCHARD ${ }^{3}$, VINCENT DINHUT $^{4}$ and JACQUES DUMAS 5
}

\begin{abstract}
A collection of crabs assembled during the KUW 2009 expedition to Mayotte Island and deposited in the Muséum national d'Histoire naturelle Paris is studied. In total 202 species are recognized, 138 of them being new records for the Island and a list of brachyuran crabs is documented and illustrated with photographs. A complementary list of all crabs previously in taxonomic literature from Mayotte and its nearest Islands (Comoros Islands, Glorieuses Islands and marine banks of Zélée, Geyser and Leven) is also provided. In total 298 crabs are identified from the region, the richness of this fauna is discussed with zoogeographic considerations and the prospects for further studies are outlined.
\end{abstract}

\section{RÉSUMÉ}

Une collection de crabes réalisée pendant la mission KUW de 2009 sur l'île de Mayotte et déposée au Muséum national d'Histoire naturelle de Paris est étudiée. Au total 202 espèces sont reconnues, 138 d'entre elles étant de nouveaux signalements pour l'île de Mayotte. Les espèces sont présentées dans une liste documentée et illustrée par des photographies. En complément une liste des crabes déjà signalés dans la littérature taxonomique de Mayotte et îles les plus proches (Iles Comores et Glorieuses ainsi que les banc marins de Zélée, Geyser et Leven) est également proposée. Au total 298 crabes sont identifiés dans cette région. La richesse de cette faune est discutée avec des considérations zoogéographiques et les perspectives pour de nouvelles études dans cette zone.

\footnotetext{
${ }^{1}$ École Navale du Poulmic, BCRM de Brest, CC 600 - Lanvéoc, F-29240 Brest cedex 09 (France), joseph.poupin@ecolenavale.fr, corresponding author

${ }^{2}$ Retired in 2010 from the Muséum national d'Histoire naturelle, Direction des Collections, Invertébrés, 61 rue Buffon, CP 53, 75231 Paris Cedex 05 (France), cleva.regis@orange.fr

${ }^{3}$ KUW C $C^{\text {ie }}$ - Kraken Underwater Works, BP 271-Kaweni, 97600 Mamoudzou, Mayotte, jmarie.bouchard@gmail.com

${ }^{4}$ ISIRUS C ${ }^{\text {ie }}$, BP 427 Kawéni, 97600 Mayotte, isirus.environnement@gmail.com

${ }^{5}$ Commission Nationale Environnement et Biologie Subaquatiques, Fédération Française d'Etude et de Sport Sous-marin, FFESSM, jacquesdumasffessm@gmail.com
} 


\section{INTRODUCTION}

This report is the third of a series published in Atoll Research Bulletin (ARB) to study the Crustacea (Decapoda) collected during the Kraken Underwater Works $\mathrm{C}^{\text {ie }}$ (KUW) expedition to Mayotte Island, southwestern Indian Ocean, November 1-21, 2009. This fieldwork was organized by J. -M. Bouchard, head of the KUW C ${ }^{\text {ie }}$ in Mayotte, with participation of the École Navale, Brest, and the Muséum national d'Histoire naturelle (MNHN), Paris (Figure 1), and was targeting primarily the Crustacea Decapoda of the Island. Financial support was provided by the DAF (Direction de l'Agriculture et de la Forêt) of Mayotte and The Total Foundation.

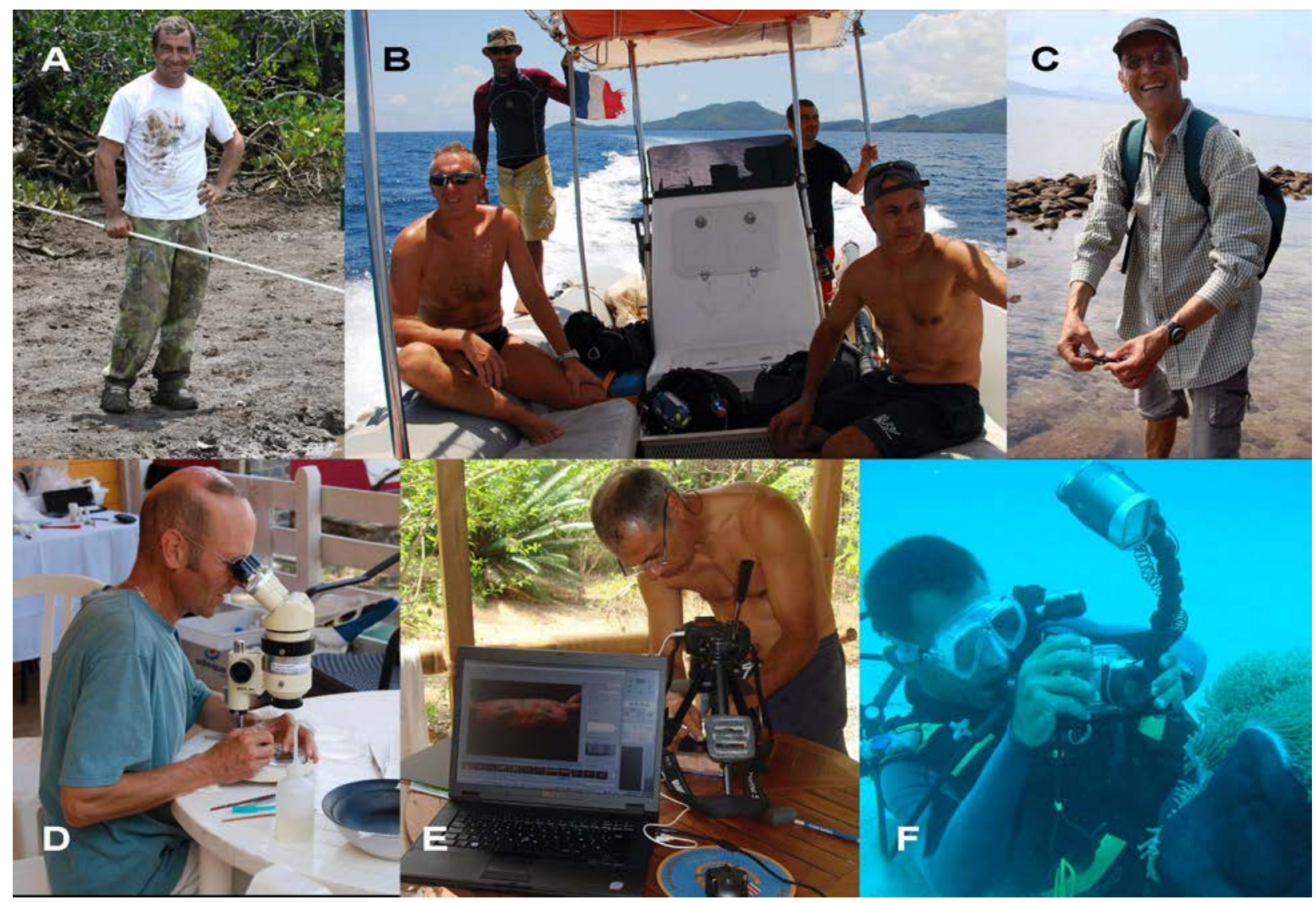

Figure 1. Participants in Mayotte KUW 2009 expedition. A) J. -M. Bouchard, mission organizer, collecting fiddler crabs in Malamani mangrove (st. 13); B) on Mayotte lagoon going to islet M'tzamboro (st. 20) on the left J. Dumas and V. Dinhut (standing), J. -M. Bouchard, steering the boat, on the right J. Poupin; C-D) R. Cleva catching a grapsid crab on Mutsumbatsou reef flat (st. 26) and sorting small specimens with stereoscopic microscope in Trévani bungalow; E) J. Poupin, at Ngouja Hotel, taking macrophotographs of a crab Liomera edwardsi (st. 27) with computer-aided equipment; F) V. Dinhut, photographing the anomuran Neopetrolisthes in situ with a giant anemone (st. 14).

The first ARB study (Bouchard et al., 2013) was dedicated to land, mangrove and freshwater Decapoda including caridean shrimps (Atyidae, Palaemonidae), anomuran (Coenobitidae) and brachyuran (Eriphioidea, Portunoidea, Grapsoidea, Ocypodoidea) and can be consulted for more details about the KUW 2009 expedition, including a documented list of the 39 stations from around the island (Figure 3).

The second ARB study (Poupin et al., 2013) was dedicated to the Anomura (Chirostyloidea, Galatheoidea, Hippoidea, Paguroidea) with the list of the species collected in Mayotte being 
complemented with previous anomuran records in Mayotte region. This is defined as an area situated between longitudes $43-48^{\circ} \mathrm{E}$ and latitudes $11-13^{\circ} 10^{\prime} \mathrm{S}$ and including the nearest islands to Mayotte, i.e. Comoros (Grande Comore, Mohéli, Anjouan) and Glorieuses Islands (Grande Glorieuse, Island du Lys) and the marine banks of Zélée, Geyser and Leven (Figures 2, 22). The main biotopes sampled in the littoral and at sea are illustrated in this contribution with a description of sampling techniques including the use of suction pump and brushing of coral blocks during scuba dives in the lagoon.

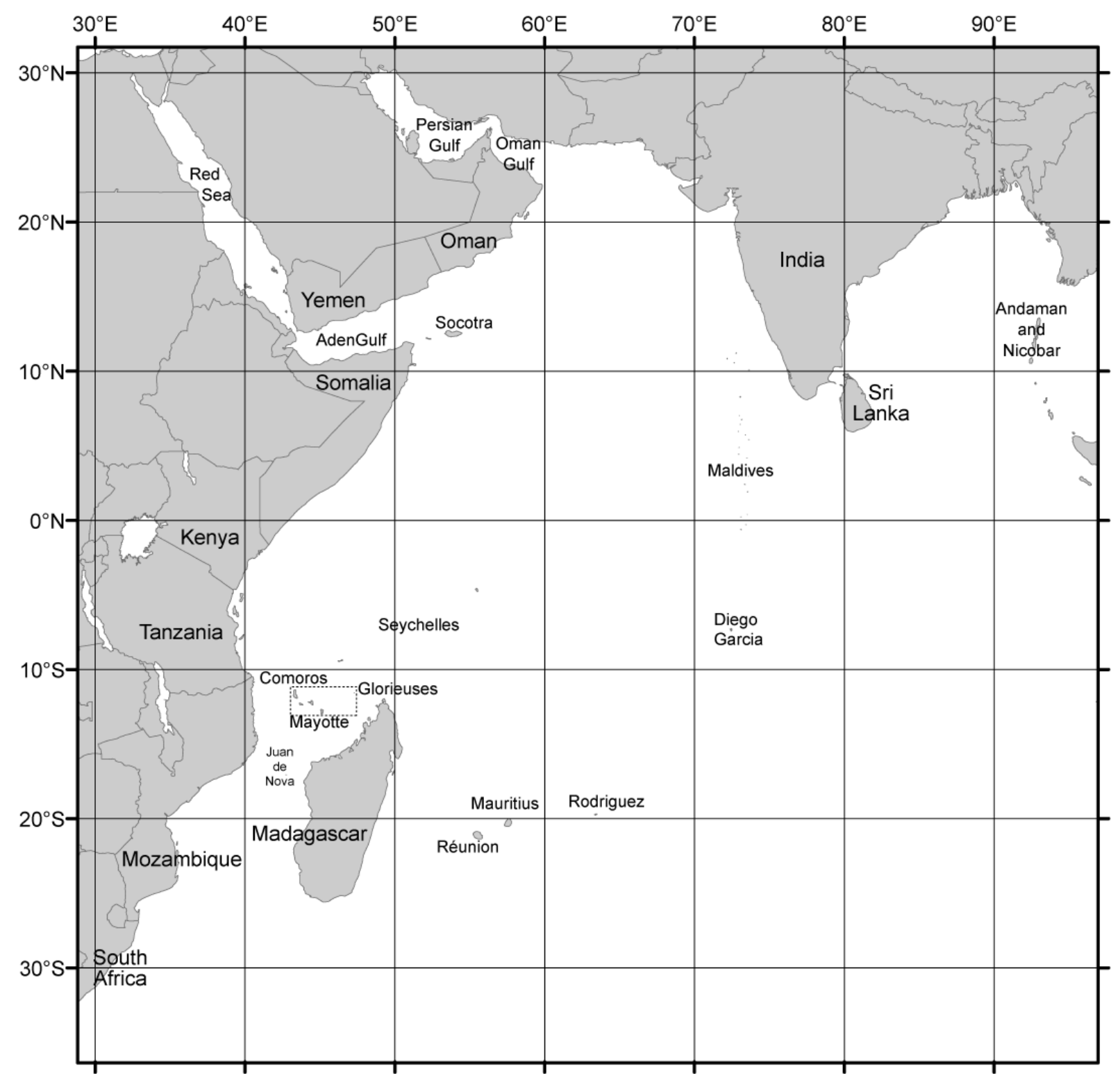

Figure 2. Western Indian Ocean (WIO) with indication of Mayotte region (dotted rectangle).

The Decapoda collected during Mayotte KUW 2009 were all deposited and registered in the MNHN. Some of this material have been also published in taxonomic revisions in others journals, including studies of the shrimps Palaemonoidea (Li et al., 2012); the anomuran Galatheidae (Macpherson and Cleva, 2010), the Paguridae (Komai and Poupin, 2012, 2013), the Porcellanidae (Osawa and Poupin, 
2013); and the brachyuran Leucosiidae (Komai and Ng, 2012) and Macrophthalmidae (Poupin and Bouchard, 2010).

This contribution aims to complete the study of the Decapoda KUW 2009 collection with respect to the brachyuran crabs. Several crabs identifications from the Mayotte KUW collection have been already included in a preliminary list of 239 species by Poupin (2010) as part of the inventory program of the French Service du Patrimoine Naturel, MNHN Paris. This first list, however, was incomplete because not documented and without illustration. The purpose of the present work, therefore, is to improve this first contribution with additional determinations and to document each crab species record with: a) the material examined, with associated MNHN number(s); b) scientific contributions with former records in Mayotte region (if any); c) remarks on systematic (were necessary); d) color photographs of specimens of almost all species collected during KUW 2009; e) and geographic and deep ranges.

A few historical landmarks for collection and study of crabs in Mayotte region are given before the documented list. The list is followed by a discussion about the richness of this fauna, the zoogeography of the species, several taxonomic issues, and the prospects for further studies in Mayotte region, especially for the deepwater fauna.

\section{METHODS}

\section{Abbreviations and acronyms}

ARB, Atoll Research Bulletin; BIORECIE, French research program 2011-2013 'Biodiversité, ressources et conservation des récifs coralliens dans le SO Océan Indien, Iles Eparses'; CL, carapace length; CW, carapace width; det., determined by; G1-G2, Male gonopods 1 and 2; IO, Indian Ocean; FLMNH, Florida Museum of Natural History, Gainesville; IP, Indo-Pacific; IWP, Indo-West Pacific; juv., juvenile; KUW, Kraken Underwater Works $C^{\text {ie; }}$ MNHN, Muséum national d'Histoire naturelle, Paris; NHM, Natural History Museum, London; ov., ovigerous; pers. comm. , personal communication; s.l., sensu lato; sp./spp., specimen/s; st., station; RMNH, Rijksmuseum van Natuurlijke Historie, Leiden;

UFID, University of Florida, identification number; WA, Western Atlantic; WIO, Western Indian Ocean.

\section{Sampling method and photographs}

The coordinates together a short description of the stations prospected (Figure 3 ) during Mayotte KUW 2009 can be consulted in Bouchard et al. (2013). The description of marine biotopes visited and sampling techniques used in the intertidal and at sea are provided by Poupin et al. (2013). In the lagoon scuba dives were made between $1-35 \mathrm{~m}$. Species were collected by hand, by brushing corals or rocks, by using sediment suction pump, and by setting traps in some stations (st. 7, 16, 22, 30) between 3-32m, targeting specifically the swimming crabs (Figure 4).

Macrophotographs of fresh species have been made, some such as Liomera edwardsi, L. guttata and Platypodia morini, being presented herein with their live color for the first time. Additional photographs have been made during the process of registration and determination, the live color being more or less faded in these cases. Only selected photographs are presented in this contribution but many of the additional photos $(\sim 660)$ are available online in two dedicated databases, one in French (Poupin et al., 2012; no longer updated after 2012) and one in English (Legall and Poupin, 2018; still updated in 2018). 


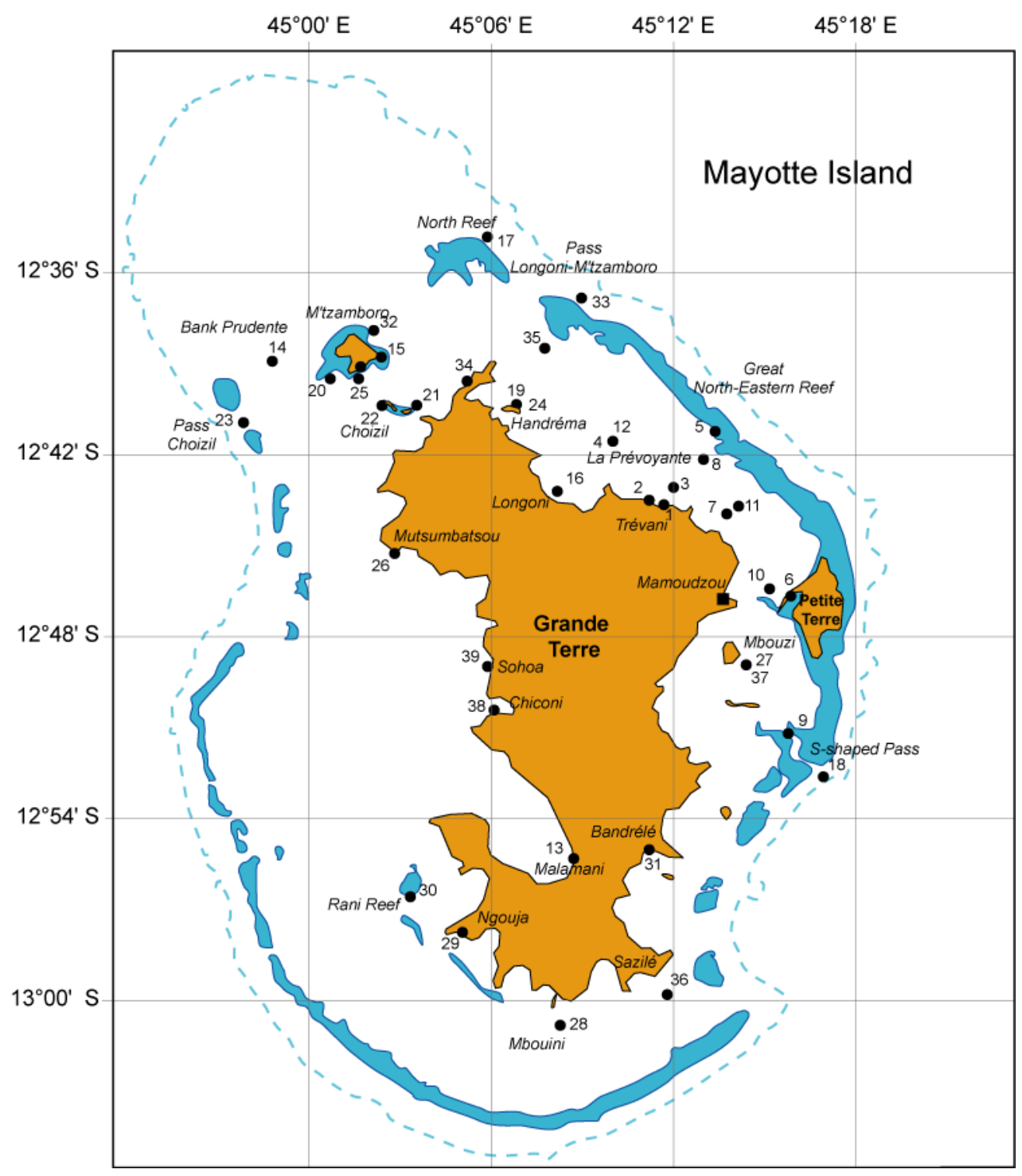

Figure 3. Map of Mayotte Island with sampling stations 1-39 (black dots) during Mayotte KUW 2009 expedition (from Bouchard et al., 2013; to be consulted for the documented list of the stations). 

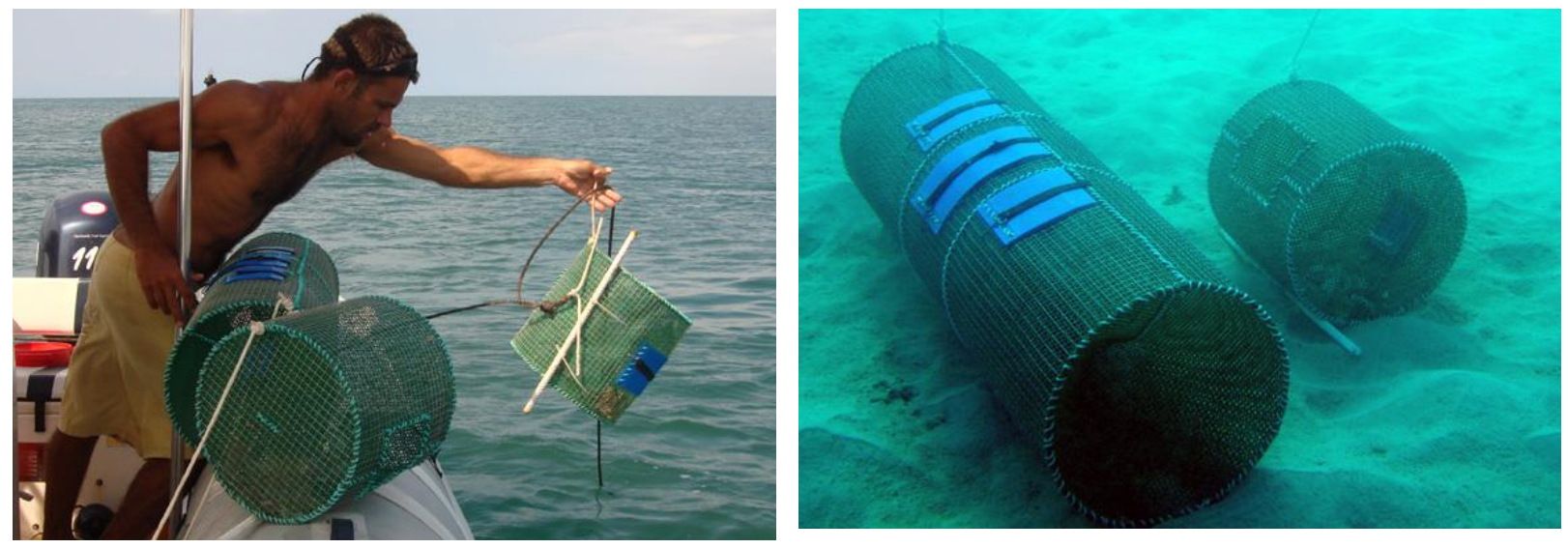

Figure 4. Traps set in Mayotte lagoon to catch swimming crabs (Portunidae). Left - Vincent Dinhut setting the traps. Right - two traps lying in the lagoon at st. 7, 32m, near 'Kongo Cardinal Buoy'.

A few Mayotte collections and observations ( 20 spp.) made in May-June 2008 by Arthur Anker and François Michonneau, during a stay sponsored by the Florida Museum of Natural History, are added to the KUW 2009 observations. This collection is deposited in FLMNH Gainesville (at FLMNH, 2018 search tool using Order=Decapoda, County=Mayotte Island).

\section{Measurement of the crabs}

The size of crabs is expressed as the largest length $(\mathrm{CL}) \times$ width $(\mathrm{CW})$ of carapace in millimeters. When long rostrum or lateral spines are present, two measures are sometimes presented (with and without rostrum/lateral spines). Due to large variations in size of species examined specimens illustrated herein cannot be presented at scale on the figures. The size of each specimen, however, is always indicated in captions of figures. Attention is drawn to the fact that many species are small, a point that is sometimes overlooked when inspecting macrophotographs of different sized species (Figure 5).

\section{Determinations}

The crabs have been mostly determined by J. Poupin, between 2009 and 2017, with participation of J. -M. Bouchard and R. Cleva at the beginning of the study (2009-2010) and appreciated help of the following carcinologists for a few taxa: P. Castro (Trapeziidae), D. Guinot (Dromiidae, Majidae, Parthenopidae), R. Naderloo (Sesarmidae), and P. K. L. Ng (Leucosiidae, Pilumnidae, Planopilumnidae).

\section{Registration of the collection}

All the Decapoda collected during Mayotte KUW 2009 expedition have been deposited and registered in the collections of the invertebrate department of the MNHN. Just after the expedition (2009- early 2010), the samples were registered by using handwritten catalog of the Muséum, with numbers such as MNHN B32282. From late 2010, the registration has been computerized with samples registered a second time by using numbers such as MNHN-IU-2009-1100. This explains why most of the samples have two numbers in the MATERIAL EXAMINED section, such as MNHN B32282, MNHN-IU-2009-1100. The last part of the new MNHN number (e.g. 2009-1100) can be used in the field 'Catalog number' in the online catalog of Paris Muséum (MNHN-Collection, 2018) to retrieve the information for each sample (specimens, collectors, geographic coordinates ...). 


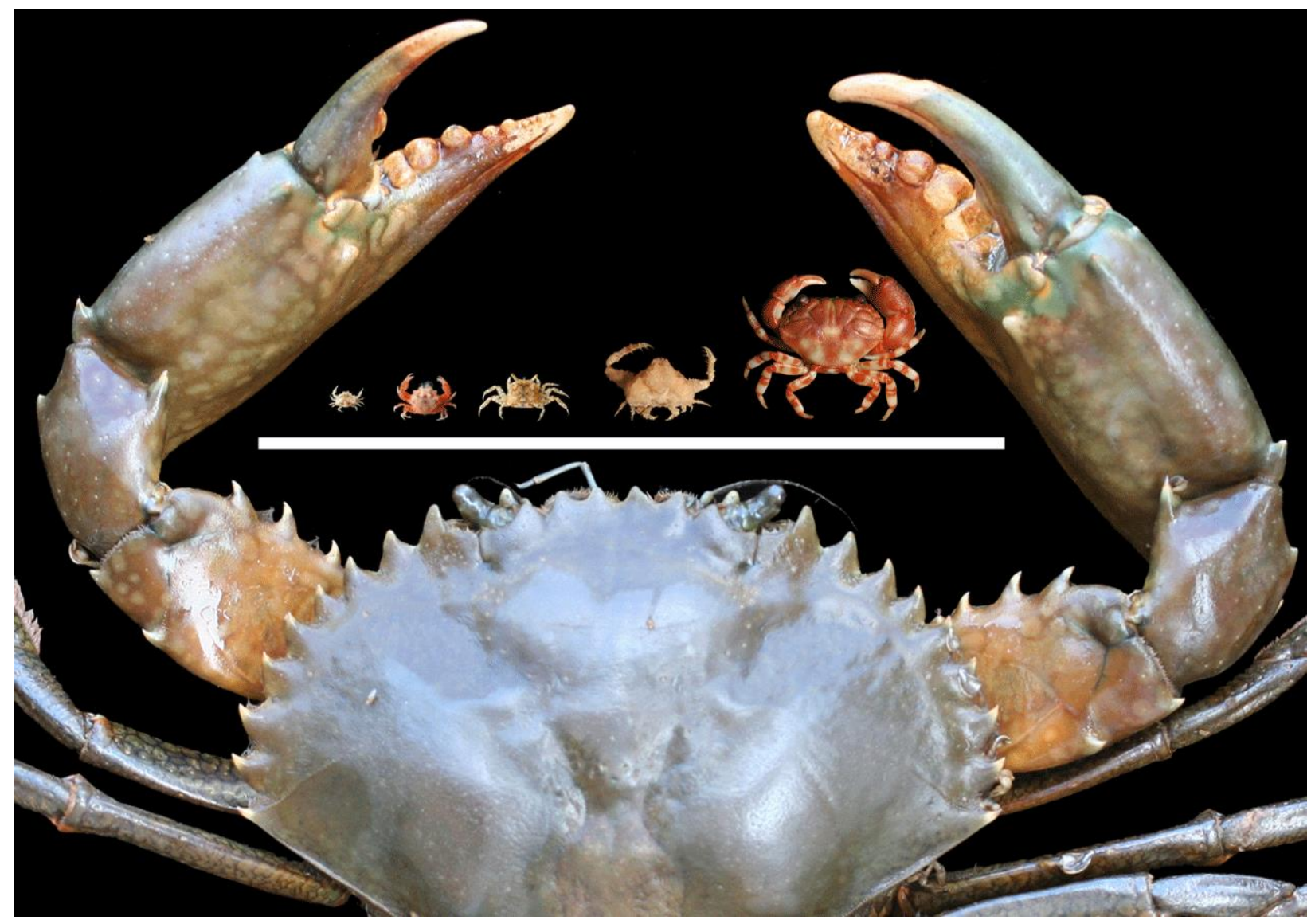

Figure 5. The importance of size measurements. The largest crab collected during the fieldwork, Scylla serrata $(093.6 \times 140 \mathrm{~mm}$ ) is illustrated on scale with a few much smaller species, from left to right above the scale bar (140 mm): Kabutos durandi (q ov. $2.84 \times 4.23 \mathrm{~mm})$, Nucia speciosa $(q 4 \times 5 \mathrm{~mm})$, Chaenostoma lisae $(0$ ov. $3.85 \times 5.1 \mathrm{~mm})$, Thyrolambrus efflorescens $(\circlearrowleft \times 12 \mathrm{~mm})$ and Lydia annulipes $(\delta 12.4 \times 19 \mathrm{~mm})$. Sizes of specimens photographed are always indicated in the captions of the figures but the species are not presented at scale.

\section{Geographic distribution and depth ranges}

The information on geographic distribution is limited to the western (northernmost to southernmost) and eastern Indo-Pacific (IP) boundaries, for example 'Red Sea, South Africa to Japan, Hawaii, French Polynesia', Mayotte being indicated only when this is a first record for this Island. The main contributions used to check the geographic distributions and depth ranges are, in alphabetical order: Castro (2011; Hawaii), Davie (2002; Australia), Emmerson (2016; South Africa), Legall and Poupin (2018; IP, including a few unpublished records), Paulay et al. (2003; Guam), Sakai (2004; IWP), Serène (1984; IWP).

\section{HISTORICAL LANDMARKS}

This attempt to reconstitute the historical records of crab collections in Mayotte region is based on the information given about collector(s) in the literature consulted. This information is often missing or limited to a place, name of collector(s), and date of collection. Many small contributions cannot be reported because of the scarcity of information, but a few main events are nonetheless identified herein (Figure 20). 
The first crabs collected from Mayotte were four Portunidae (Charybdis feriata, C. natator, Scylla serrata, and Thalamita prymna), in 1864 by F.P.L. Pollen and D.C. Van Dam during their 'Recherches sur la Faune de Madagascar et des ses dépendances' and reported in Hoffmann (1874). A narration of this expedition is given by Pollen (1868) and the collection deposited in RMNH Leyden Museum (see Bouchard et al., 2013).

In ca. 1880, a collection of forty or so crabs was made in Mayotte by Ed. Marie, 'sous-commissaire' of the French Navy, and deposited in MNHN. Guinot (1957) indicates that his collection included only one new Portunidae, that she described and named after Ed. Marie (Portunus mariei), and 24 xanthid crabs that are reported in Guinot (1958a-c). It seems that his collection from Mayotte includes a few more specimens other than those described by Guinot (1957, 1958a-c) Castro (1999a) examined additional crabs collected by Ed. Marie from Mayotte (e.g. Trapezia guttata, Tetralia rubridactyla).

In 1882 H.M.S. Alert put in near Mayotte in the Glorieuses Islands with five crabs, Eriphia sebana, E. smithii, Thalamita sima, Trapezia cymodoce, and T. rufopunctata, reported from this voyage by Miers (1884).

From 1903-1905, during his travels to East Africa, the German zoologist Alfred Voeltzkow has collected several crabs in Mayotte and Comoros Islands, namely Actaeodes tomentosus, Epixanthus frontalis, Sesarmops impressus, and Varuna litterata. These were all reported by Lenz (1910) in his contribution on the 'Crustaceen von Madagaskar, Ostafrika und Ceylon'.

Between 1914-1955, there were few sporadic collections from Mayotte deposited in various museums: United States Museum of Natural History, Ptychognathus johannae from Anjouan Island, received in exchange from Berlin Museum (cf. Rathbun, 1914); Naturhistorisches Museum, Wien, Psaumis cavipes (Odhner, 1925); and MNHN for miscellaneous small collections, collectors being Messrs. Humblot, Millot, and Fourmanoir in Balss (1934), for Dromidiopsis tridentata, Lewindromia unidentata, Macromedaeus voeltzkowi, Medaeops neglectus, and in Barnard (1954), for Libystes nitidus.

Between 1958 and 1971, an important crab collection has been assembled from Mayotte region by Alain Crosnier, Centre d'Océanographie et des Pêches (ORSTOM), Nosy Be, Madagascar. The collection by Crosnier was mainly undertaken in 1959 from Mayotte during a geomorphologic campaign aboard the R/V ORSTOM II (see Guilcher et al., 1965); other collections were from Anjouan (November 1961) and Glorieuses Islands (September 1958, January 1971. In total at least 80 crabs have been identified from Crosnier's collections in this region. This collection has been identified for the Portunidae (Crosnier, 1962); Grapsidae and Ocypodidae (Crosnier, 1965); Xanthidae and Trapeziidae (Serène, 1984); and Carpiliidae and Menippidae (Crosnier, 1984). Other references to the crab collection of Crosnier appear more discreetly in Castro (1997, 1998), Clark \& Galil (1993), Galil (1997, 2005), Guinot (1958a, 1964b), McLay (1999) and Tan \& Ng (2007).

Pascale Chabanet lead the BIORECIE 2 leg to the Glorieuses Islands in December (5-17) 2012 and the Decapoda were identified by J. Poupin. Although completed after Mayotte KUW 2009, the crab inventory was published (Poupin et al., 2013c) with ca. 60 crabs being reported, including 18 new records for the region. 


\section{CRABS OF MAYOTTE KUW 2009 EXPEDITION}

The taxonomy of the list follows WoRMS (2018) which is based on the following contributions for the Brachyura: list of genera and higher taxa (De Grave et al., 2009) and crabs (Ng et al., 2008). Updates for these core contributions have been integrated as required, for example for the authorship of the nomen Brachyura (Guinot et al., 2013) or new fiddler crabs genera $U c a$ sensu lato (Shih et al., 2016). Terrestrial crabs have been previously studied by Bouchard et al. (2013). Their material examined is nonetheless listed again herein, including the new MNHN numbers that were not available in their contribution. References, comments and photos for these species are not repeated as they can be found in Bouchard et al. (2013).

\section{Order Decapoda Latreille, 1802}

\section{Infra Order Brachyura Latreille, 1802}

\section{Superfamily Dromioidea De Haan, 1833}

\section{Family Dromiidae De Haan, 1833}

Stebbingdromia plumosa (Lewinsohn, 1984) (Figure 6A)

MATERIAL EXAMINED - Mayotte KUW 2009, st. 23, Pass Choizil 'Patate à Teddy', 15-30m, 1ð̂ 4.9×5.2 mm, MNHN-IU-2009-3227.

REMARKS - Determination of this specimen is based on characters given in Guinot and Tavares (2003: 91) including aspect of orbits, ocular peduncles, front, lateral margins of carapace and G2 shorter than G1. The epipods on the chelipeds as indicated by Guinot and Tavares (2003) were not observed but McLay (2001: 843) has recorded that these lateral extensions were mentioned erroneously by Lewinsohn (1984) when describing the species. Danièle Guinot has verified our determination indicating that the G2 is not styliform in this species, a character unique within the Dromiinae used by Števčić (2005) for creating the new Stebbingdromiini tribe.

GEOGRAPHIC AND DEPTH RANGES — IWP, Mayotte (present study), Seychelles to New Caledonia, Hawaii; shallow subtidal, $15-55 \mathrm{~m}$.

Tumidodromia dormia (Linnaeus, 1763) (Figure 6B)

MATERIAL EXAMINED - Mayotte KUW 2009, st. 12, La Prévoyante Reef at night, 6-12m, 1 q 87.5×106 mm, 1 ô 126×160 mm, MNHN-IU-2009-1157.

GEOGRAPHIC AND DEPTH RANGES - IWP, Red Sea, Mozambique, Mayotte (present study) to Hawaii, French Polynesia; subtidal, 8-156m.

\section{Family Dynomenidae Ortmann, 1892}

\section{Hirsutodynomene spinosa (Rathbun, 1911) (Figure 6C)}

MATERIAL EXAMINED - Mayotte KUW 2009, st. 25, south Islet M'tzamboro, 15-20m, 1 q $6.7 \times 7.8 \mathrm{~mm}$, MNHN-IU-2009-3226; st. 35, Surprise Reef, Pass Longoni-M'tzamboro, 4-25m, 1 q juv. 6.0×6.75 mm, MNHN B32427, MNHN-IU-2009-1189.

OTHER RECORDS - Hirsutodynomene spinosa - McLay, 1999: 505, Glorieuses, intertidal, coll. A. Crosnier, 30 January 1971, 1ठ 16.4×14.3 mm, MNHN B 6899.

GEOGRAPHIC AND DEPTH RANGES - IWP, Glorieuses, Madagascar to Japan, French Polynesia; intertidal to $40 \mathrm{~m}$ (maximum depth of $40 \mathrm{~m}$ from unpublished field observation in French Polynesia, BENTHAUS 2002 campaign, st. DW1984, det. A. Crosnier). 


\section{Superfamily Aethroidea Dana, 1851}

\section{Family Aethridae Dana, 1851}

Aethra edentata Edmondson, 1951 (Figure 6D)

MATERIAL EXAMINED - Mayotte KUW 2009, st. 25, south Islet M'tzamboro, 15-20m, 1 19.4×30.3 mm, MNHN B32402, MNHN-IU-2009-1164.

OTHER RECORDS - Mayotte, 'Buoy n ${ }^{\circ} 8$ in S-shaped Pass', no specimen only in situ photograph by Matthias Deuss, July 2011, det. J. Poupin based on dentition on chelipeds and lateral margins of carapace almost absent (photos in Legall and Poupin, 2018).

REMARKS - Following Ng (1999, key) the small specimen examined from Mayotte KUW 2009 is $A$. edentata, having no teeth on lower margin of palms of chelipeds (vs. teeth present in affiliated $A$. scruposa). The aspect of its carapace, almost smooth, matches the photograph of $A$. edentata type specimen in $\mathrm{Ng}(1999$, fig. 3, a female of comparable size $19.6 \times 30 \mathrm{~mm})$. Aethra edentata and $A$. scruposa are close species, the former sometimes considered as a subspecies of the latter. Examination of series of specimens comprising different sizes would be useful to confirm the status of $A$. edentata.

GEOGRAPHIC AND DEPTH RANGES - IWP, Mayotte (present study, first record in IO) to Hawaii, French Polynesia; 1-106m.

\section{Aethra scruposa (Linnaeus, 1764) (Figure 6E)}

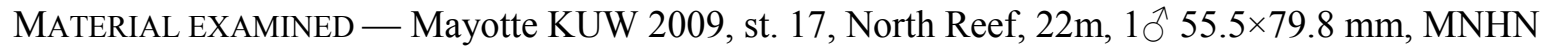
B32401, MNHN-IU-2009-1163.

REMARKS - Aethra seychellensis Takeda, 1975 from Seychelles cannot be confused with $A$. scruposa because of its characteristic gastric projection (high, sublamelliform, posteriorly directed) and by the aspect of its posterolateral margins of carapace (strongly upturned).

GEOGRAPHIC AND DEPTH RANGES — IWP, Mayotte (present study), Réunion, Mauritius to Japan, Cook Islands; 1-200m. This species is sometimes reported from East Africa (e.g. Sakai, 2004), perhaps from the list by Guinot (1967b: 299). No confirmed records of this species from the African coast, however, were retrieved during this study. The present record from Mayotte, therefore, is perhaps the westernmost IWP limit for this crab.

\section{Superfamily Calappoidea De Haan, 1833}

\section{Family Calappidae De Haan, 1833}

\section{Calappa gallus (Herbst, 1803)}

MATERIAL eXAMINED - Mayotte KUW 2009, st. 23, Pass Choizil 'Patate à Teddy', 15-30m, only remains of carapace (not retained in MNHN collection), field det. J. Poupin.

OTHER RECORDS - Calappa gallus - Galil, 1997: 293, Glorieuses, intertidal, 30 January 1971, coll. A. Crosnier, 1 + $24.6 \mathrm{~mm}, \mathrm{MNHN}$.

GEOGRAPHIC AND DEPTH RANGES - IWP, Red Sea, Mayotte (present study), South Africa to Hawaii, French Polynesia; intertidal to $216 \mathrm{~m}$. 


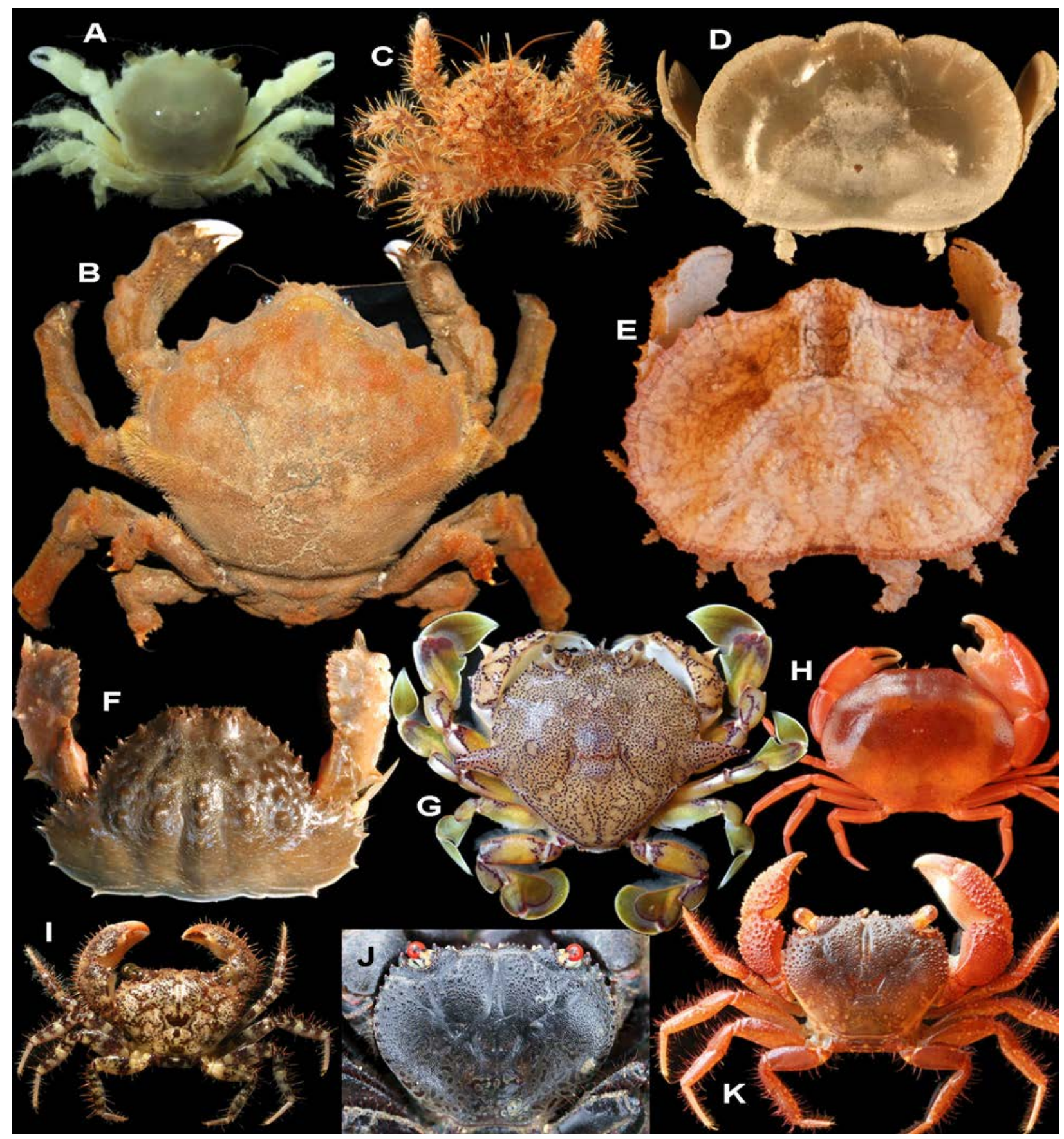

Figure 6. Crabs from Mayotte KUW 2009. Dromioidea - A) Stebbingdromia plumosa $1 \bigcirc 4.9 \times 5.2 \mathrm{~mm}$, MNHN-IU-2009-3227 (preserved); B) Tumidodromia dormia 1 ㅇ 87.5×106 mm, MNHN-IU-2009-1157; C) Hirsutodynomene spinosa, 1 juv. $6.0 \times 6.75 \mathrm{~mm}$, MNHN-IU-2009-1189. Aethroidea - D) Aethra edentata, 1 \% $19.4 \times 30.3 \mathrm{~mm}$, MNHN-IU-2009-1164 (preserved); E) A. scruposa, $1 \bigcirc 55.5 \times 79.8 \mathrm{~mm}$, MNHN-IU-2009-1163. Calappoidea - F) Calappa hepatica, $1 \bigcirc^{\top} 20.7 \times 22.6 \mathrm{~mm}$, MNHN-IU-2009-1077 (preserved); G) Matuta victor $1 \overbrace{}^{\lambda} 23.5 \times 36.0 \mathrm{~mm}$ (with lateral spines) MNHN-IU-2009-1170.

Carpilioidea - H) Carpilius convexus, $1 \hat{\jmath} 12 \times 16.5 \mathrm{~mm}$, MNHN-IU-2009-1106. Eriphiidae - I) Eriphia scabricula, 1 đ̊ $9.5 \times 14 \mathrm{~mm}$, MNHN-IU-2009-1213; J) E. sebana, sp. not collected, size about $33 \times 45 \mathrm{~mm}$, Petite Terre 'Déversoir Badamiers';K) Eriphia smithi, 1つ’14.6×19.4 mm, MNHN-IU-2009-1177. 
Calappa hepatica (Linnaeus, 1758) (Figure 6F)

Material eXAMINED - Mayotte KUW 2009, st. 23, Pass Choizil 'Patate à Teddy', 15-30m, carapace only, not retained in collection; coll. J. -M. Bouchard, V. Dinhut scuba dive December 2009, mud bottom harbor, Mamoudzou, 7-8m, $1 \overbrace{}^{\Uparrow} 20.7 \times 22.6$ mm, 1 juv., MNHN B32259, MNHN-IU-20091077.

OTHER RECORDS - Calappa hepatica - Galil, 1997: 297, Glorieuses, intertidal, 30 January 1971, coll. A. Crosnier, 1 đ $22.8 \mathrm{~mm}, \mathrm{MNHN}$.

REMARKS - The largest specimen examined $(ð 20.7 \times 22.6 \mathrm{~mm}$ ) has a carapace length/width ratio of 1.63 instead of 1.4 in the affiliated C. woodmasoni, a species also present in Mayotte (see Appendix). Mayotte specimens of $C$. hepatica belong to the 'spiniform teeth form' formerly reported as a separate species, Calappa spinosissima H. Milne Edwards, 1837. This species is now treated as a junior synonym of $C$. hepatica because of large variation of the 'spiniform teeth' observed in series of specimens (see remarks in Galil, 1997: 299).

GEOGRAPHIC AND DEPTH RANGES - IWP, Red Sea, Mayotte (present study), South Africa to Hawaii, French Polynesia, and Clipperton; intertidal to $150 \mathrm{~m}$; introduced to the Mediterranean Sea (Galil et al., 2018).

\section{Family Matutidae De Haan, 1835}

Matuta victor (Fabricius, 1781) (Figure 6G)

MATERIAL EXAMINED - Mayotte KUW 2009, st. 1, beach, Trévani, buried in sand 0.5m, 1 ^ 23.5×36.0 mm (with lateral spines), MNHN B32408, MNHN-IU-2009-1170; coll. J. -M. Bouchard, 1 July 2009, 1 우 27.3×30 mm, 1 juv., MNHN B32406, MNHN-IU-2009-1168; coll. J. -M. Bouchard 2006-2009, 1 ภิ 27.6×28.5 mm (without lateral spines), MNHN B32407, MNHN-IU-2009-1169.

OTHER RECORDS - Matuta victor - Galil and Clark, 1994: 39, Mayotte, coll. R. von Hentig, July 1972, $1 \hat{\jmath}$, RMNH D29256.

GEOGRAPHIC AND DEPTH RANGES - IWP, Red Sea, South Africa to French Polynesia (report in French Polynesia documented in Legall and Poupin, 2018); intertidal to shallow subtidal.

\section{Superfamily Carpilioidea Ortmann, 1893}

\section{Family Carpiliidae Ortmann, 1893}

\section{Carpilius convexus (Forskål, 1775) (Figure 6H)}

MATERIAL EXAMINED - Mayotte KUW 2009, st. 23, Pass Choizil 'Patate à Teddy', 15-30m, 1 đ̊ $12 \times 16.5 \mathrm{~mm}, \mathrm{MNHN}$ B32288, MNHN-IU-2009-1106 (also several carapaces, not retained in the collection).

OTHER RECORDS - Carpilius convexus - Crosnier, 1984: 302, Glorieuses. - Coll. Anker and Michonneau, 2008, Mayotte, st. MAY08-St6, S-shaped Pass, UFID 13682. - Poupin et al., 2013c: 11, Glorieuses.

GEOGRAPHIC AND DEPTH RANGES - IWP, Red Sea, South Africa to Clipperton, Easter Island; intertidal to $95 \mathrm{~m}$ (95 m from unpublished field observation in French Polynesia, BENTHAUS 2002 Expedition, st. CAS1976, Arago Bank, 90-95 m).

\section{Superfamily Eriphioidea MacLeay, 1838}

\section{Family Eriphiidae MacLeay, 1838}


Eriphia scabricula Dana, 1852 (Figure 6I)

MATERIAL EXAMINED - Mayotte KUW 2009, st. 2, 10 9.5×14 mm, MNHN B32451, MNHN-IU-20091213; st. 10, east Islet 'Quatre frères, Vatou', intertidal, 1 §’, 1 \%, MNHN B32452, MNHN-IU-20091214; st. 26, Mutsumbatsou reef flat, intertidal, $1 \overbrace{}^{\Uparrow} 15.3 \times 21.4 \mathrm{~mm}$, perhaps also 19 juv., MNHN B32450, MNHN-IU-2009-1212.

OTHER RECORDS - Eriphia scabricula - Crosnier, 1984: 311, Anjouan, Mayotte, Glorieuses. - Poupin et al., 2013c: 11, Glorieuses.

GeOGRAPHIC AND DEPTH RANGES - IWP, Red Sea, South Africa to Japan, French Polynesia; intertidal to subtidal.

Eriphia sebana (Shaw and Nodder, 1803) (Figure 6J)

MATERIAL EXAMINED - Mayotte KUW 2009, st. 2 field observation, no specimen; st. 6 photograph only, specimen not collected (size about $33 \times 45 \mathrm{~mm}$ ); st. 26, Mutsumbatsou reef flat, intertidal, 10 $43 \times 55$ mm, MNHN B32405, MNHN-IU-2009-1167.

OTHER RECORDS - Eriphia laevimana - Miers, 1884: 534, Glorieuses / Eriphia laevimana Guérin, 1829 accepted as E. sebana in WoRMS (2018). - Eriphia sebana - Guinot, 1967b: 271, list with Glorieuses. - Crosnier, 1984: 311, Glorieuses. - Poupin et al., 2013c: 11, Glorieuses.

GEOGRAPHIC AND DEPTH RANGES — Red Sea, South Africa to Hawaii, French Polynesia; intertidal to subtidal.

Eriphia smithii MacLeay, 1838 (Figure 6K)

MATERIAL EXAMINED - Mayotte KUW 2009, st. 2, littoral, between Trévani beach and Kangani Mangrove, 10 $34.2 \times 44.5$ mm, MNHN B32413, MNHN-IU-2009-1175; st. 26, Mutsumbatsou reef flat, 1 ○ 14.6×19.4 mm, MNHN B32415, MNHN-IU-2009-1177; st. 26b, Mutsumbatsou reef flat, coll. J. -M. Bouchard, 3 August 2008, 1 ov. 25×33 mm, MNHN B32414, MNHN-IU-2009-1176.

OTHER RECORDS - Eriphia laevimanus var. smithii - Miers, 1884: 535, Glorieuses. - Eriphia smithi Guinot, 1967b: 271, list with Glorieuses. - Poupin et al., 2013c: 11, Glorieuses.

REMARKS - Eriphia smithii resembles E. sebana but can be separated by the aspect of the outer face of the chela: tubercles in E. smithii (vs. smooth in E. sebana and in live specimens the eyes of E. smithii are pale yellow (vs. bright red in E. sebana). For a revision of Eriphia see Koh and $\mathrm{Ng}$ (2008) for more characters to recognize these two species.

GEOGRAPHIC AND DEPTH RANGES - WIO, Red Sea, South Africa to Seychelles, Madagascar; intertidal to subtidal.

\section{Family Oziidae Dana, 1851}

Epixanthus corrosus A. Milne-Edwards, 1873 (Figure 7A)

MATERIAL EXAMINED - Mayotte KUW 2009, st. 10, east Islet 'Quatre frères, Vatou', intertidal, $2 \widehat{\jmath} \widehat{\jmath}$ $5.4 \times 9.6 \mathrm{~mm}, 9.7 \times 16 \mathrm{~mm}, \mathrm{MNHN}$ B32435, MNHN-IU-2009-1197; st. 26, Mutsumbatsou reef flat, intertidal, low tide, 1 o $^{7} 8.2 \times 14.2 \mathrm{~mm}$, MNHN B32436, MNHN-IU-2009-1198.

OTHER RECORDS - Epixanthus corrosus - Guinot, 1958c: 276, Mayotte, 1 + $6 \times 4 \mathrm{~mm}$ MNHN. - Guinot, 1967b: 270, list with Mayotte. - Crosnier, 1984: 307, Mayotte.

GEOGRAPHIC AND DEPTH RANGES - IWP, Red Sea, Mayotte to Japan, New Caledonia; intertidal to subtidal.

Epixanthus dentatus (White, 1848) (Figure 7B)

MATERIAL EXAMINED - Mayotte KUW 2009, st. 13, Malamani mangrove, 10 $17.8 \times 29 \mathrm{~mm}$, MNHN B32465, MNHN-IU-2009-1227. 
REMARKS - This species has already been presented in the mangrove species for Mayotte published in Bouchard et al. (2013: 14).

GEOGRAPHIC AND DEPTH RANGES - IWP, Kenya, Mayotte (present study) to Japan, Fiji; intertidal, subtidal.

\section{Epixanthus frontalis (H. Milne Edwards, 1834) (Figure 7C)}

MATERIAL EXAMINED - Mayotte KUW 2009, st. 2, 1ð 12.6×20.7 mm, MNHN B32461, MNHN-IU2009-1223, 1 §, 2 우, MNHN B32460, MNHN-IU-2009-1222; st. 10, 1 ㅇ 11.1×18.4 mm, MNHN-IU2009-2599; st. $26,1{ }^{\top} 14.5 \times 23 \mathrm{~mm}, 1$ \% juv. $9.0 \times 14.3 \mathrm{~mm}$, MNHN-IU-2009-2600; st. 29, intertidal, beach, Mboianatsa, Ngouja Hotel, 1 + $17.8 \times 30.6$ mm, MNHN B32462, MNHN-IU-2009-1224.

OTHER RECORDS - Epixanthus frontalis - Lenz, 1910: 552, Grande Comore. - Guinot, 1958c: 276, Mayotte, 1 9 8×5 mm MNHN. - Guinot, 1967b: 270, list with Mayotte. - Crosnier, 1984: 307, Mayotte.

REMARKS - In field notes (st. 10, 26) several specimens erroneously indicated as 'Pseudozius caystrus', corrected into $E$. frontalis after careful re-examination. Although the two species have superficial resemblances they can be easily differentiated by the aspect of male G2: short without distal flagellum, in P. caystrus (elongated with a long cross-shaped (or coiled) distal flagellum in E. frontalis).

GEOGRAPHIC AND DEPTH RANGES - IWP, Red Sea, South Africa to Japan, Tuvalu; intertidal, subtidal.

Eupilumnus calmani (Balss, 1933) (Figure 7D)

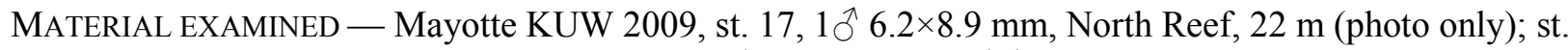

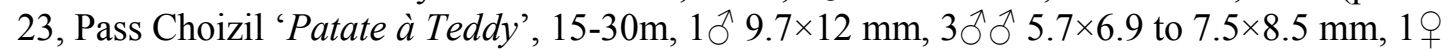
$10.9 \times 13.5$ mm, MNHN-IU-2013-7223; st. 35, Surprise Reef, Pass Longoni-M’tzamboro, 4-25m, 1 q $6.4 \times 7.7 \mathrm{~mm}, \mathrm{MNHN}-\mathrm{IU}-2013-7224$.

OTHER RECORDS - Poupin et al., 2013c: 11, Glorieuses.

REMARKS - In field notes these specimens were erroneously identified as 'Pilodius cf. flavus', corrected into Eupilumnus calmani after careful examination. Description and figures for E. calmani (including male G1/G2) are in Guinot-Dumortier (1960). It is affiliated to E. actumnoides (A. Milne-Edwards, 1873) from the western Pacific (Japan, Papua New Guinea, New Caledonia, Samoa, Kiribati, Australia). Guinot-Dumortier (1960) has indicated several differences between the two species including: a) the aspect of anterolateral spines on the carapace, sharp and long in E. calmani (vs. reduced in E. actumnoides); b) a stridulating apparatus on P2 merus and cheliped (see GuinotDumortier, 1960: 113, fig. 11) in E. calmani (vs. absent in E. actumnoides).

GEOGRAPHIC AND DEPTH RANGES - IWP, Red Sea, Tanzania to China Sea, French Polynesia; intertidal to $174 \mathrm{~m}$. Distribution extended herein to French Polynesia from specimen collected in the Tuamotu (Mataiva) determined in Moorea CRIOBE collection in 2014 by J. Poupin (photos in Legall and Poupin, 2018).

Lydia annulipes (H. Milne Edwards, 1834) (Figure 7E)

MATERIAL EXAMINED - Mayotte KUW 2009, st. 10, 1ð 12.4×19 mm, MNHN B32468, MNHN-IU2009-1230.

OTHER RECORDS - Lydia annulipes - Crosnier, 1984: 309, Glorieuses. - Poupin et al., 2013c: 11, Glorieuses.

REMARKS - Crosnier (1984: 309) has indicated that this species can be confused with Lydia tenax (Rüppell, 1830) and has given a few characters useful to separate both species with this comment ' $L a$ distinction de ces deux espèces n'est pas évidente et ce d'autant plus que, dans le genre Lydia, les spécimens d'une même espèce semblent présenter des variations individuelles importantes de la granulation des chélipèdes ainsi que de la granulation et du relief de la carapace'.GEOGRAPHIC AND DEPTH RANGES - IWP, Tanzania, South Africa to Hawaii, French Polynesia; intertidal. 


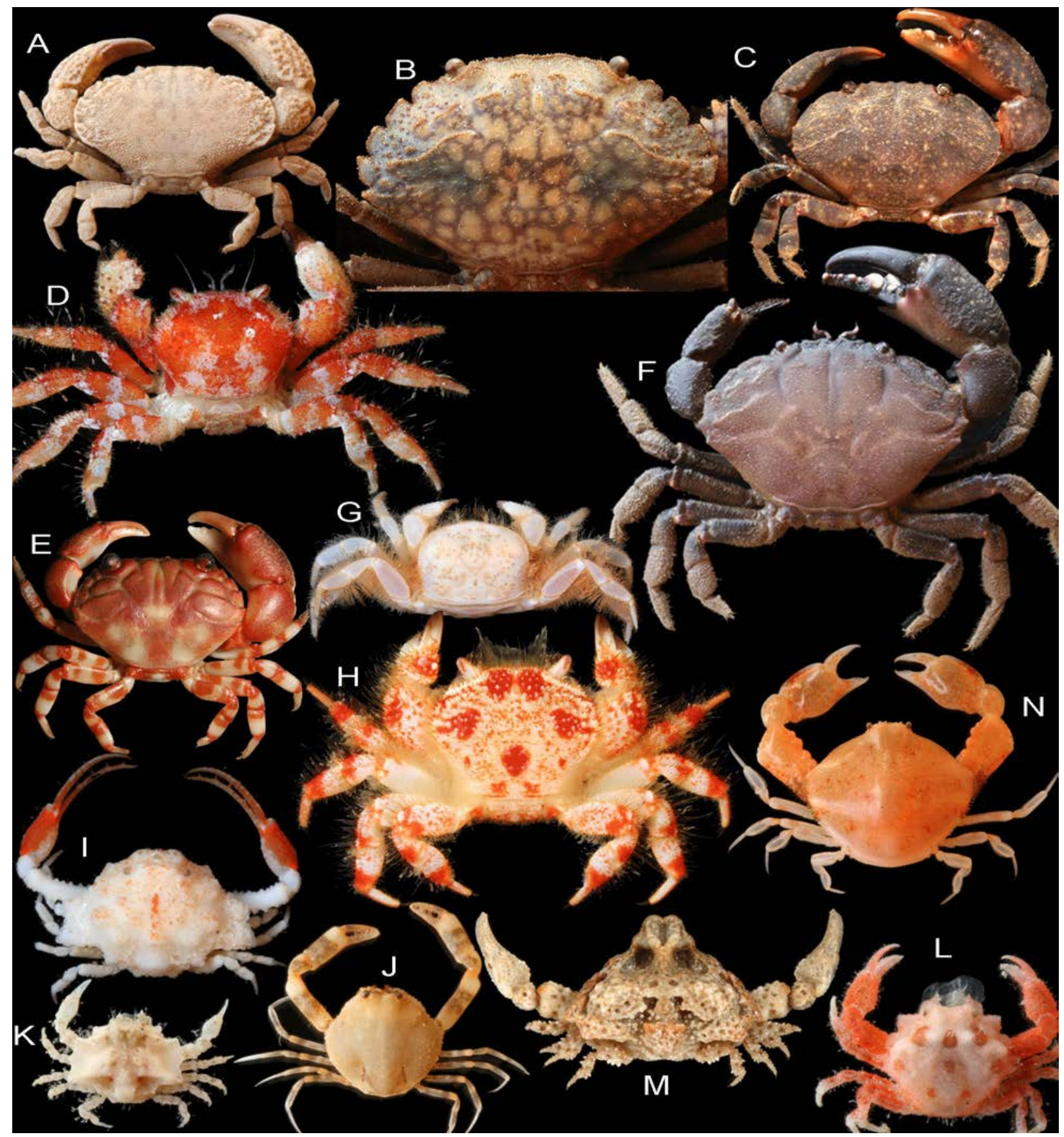

Figure 7. Crabs from Mayotte KUW 2009. Oziidae - A) Epixanthus corrosus, probably $1 \delta^{\Uparrow} 9.7 \times 16 \mathrm{~mm}$,

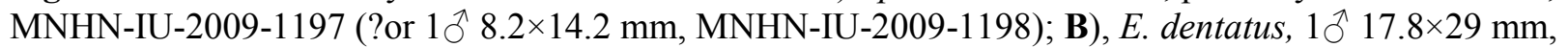
MNHN-IU-2009-1227; C) E. frontalis, 1 ô 12.6×20.7 mm, MNHN-IU-2009-1223; D) Eupilumnus calmani, $1{ }^{\Uparrow} 9.7 \times 12 \mathrm{~mm}$, st. 23, MNHN-IU-2013-7223; E) Lydia annulipes, 10 12.4×19 mm, MNHN-IU-20091230; F) Ozius rugulosus, $1925 \times 38$ mm, MNHN-IU-2009-1180. Acidopsidae - G) ?Caecopilumnus piroculatus, 1 \% 5.9 $\times 7.9 \mathrm{~mm}$, MNHN-IU-2013-7225; H) Parapilumnus cristimanus, 1 q $12.18 \times 14.91 \mathrm{~mm}$, MNHN-IU-2009-1153. Leucosiidae - I) Coralliocryptus caementa, 1 \& 5.4×8.8 mm, MNHN-IU-20092127; J) ? Hiplyra elegans, 1 q juv. $4.75 \times 4.85$ mm, MNHN-IU-2013-7218 (preserved); K) Kabutos durandi, 1 ov $2.84 \times 4.23$ mm, MNHN-IU-2009-2129; L) Nucia speciosa, 1 q juv. $4 \times 5$ mm, MNHN-IU2013-7219; M) Oreophorus horridus, $1 \overbrace{}^{\Uparrow} 7.0 \times 10.0$ mm, MNHN B32264 (preserved); N) Urnalana elata, 1 ㅇ 7.1×8.4 mm, MNHN-IU-2013-7220. 


\section{Ozius rugulosus Stimpson, 1858 (Figure 7F)}

MATERIAL EXAMINED - Mayotte KUW 2009, st. 6, 'Déversoir Badamiers' Petite Terre, 1 q 25×38 mm, MNHN B32418, MNHN-IU-2009-1180; st. 10, east Islet 'Quatre frères, Vatou', intertidal, 1 , MNHN B32420, MNHN-IU-2009-1182; st. 29, beach, Mboianatsa, Ngouja Hotel, $1 \overbrace{}^{\Uparrow} 14 \times 21.5 \mathrm{~mm}$, 2 우우 $25 \times 37 \mathrm{~mm}, 27 \times 42 \mathrm{~mm}, \mathrm{MNHN}$ B32419, MNHN-IU-2009-1181.

OTHER RECORDS - Ozius rugulosus - Crosnier, 1984: 305, Mayotte. - Coll. Anker and Michonneau, 2008, Mayotte, st. MAY08-St7, Ngouja Reef, UFID 136631.

GEOGRAPHIC AND DEPTH RANGES — IWP, Red Sea, Kenya to Japan, French Polynesia; intertidal.

\section{Superfamily Goneplacoidea MacLeay, 1838}

\section{Family Acidopsidae Števčić, 2005}

\section{?Caecopilumnus piroculatus (Rathbun, 1911) (Figure 7G)}

MATERIAL EXAMINED - Mayotte KUW 2009, st. 19, north Islet Handréma, 6-10m, 1 9 5.9×7.9 mm, MNHN-IU-2013-7225.

REMARKS - This specimen has been tentatively determined by using photos and description in Rathbun (1911). Caecopilumnus piroculatus has been described from three females (1 adult, 2 juv.) collected in the Seychelles (Amirantes) not far from Mayotte. Present determination is made with hesitation because no comparative specimens were examined. Some records of $C$. piroculatus from South Africa (Barnard, 1955) and Indonesia (Serène, 1964) have been assigned by $\mathrm{Ng}$ (1987) and Ng et al. (2008: 76) to Raoulia limosa $\mathrm{Ng}, 1987$ based on the aspect of male abdomen with segments 3-5 fused in $R$. limosa (vs. segments 3-5 free in C. piroculatus). Unfortunately the specimen from Mayotte being a female this character cannot be verified herein.

GEOGRAPHIC AND DEPTH RANGES - IWP, ?Mayotte (present study), Seychelles to Philippines, ?Kiribati (Gilbert Islands); 6-65m.

Parapilumnus cristimanus (A. Milne-Edwards, 1873) (Figure 7H)

MATERIAL EXAMINED - Mayotte KUW 2009, st. 23, Pass Choizil 'Patate à Teddy', 15-30m, 1 q 12.18×14.91 mm, MNHN-B32380, MNHN-IU-2009-1153.

REMARKS - Parapilumnus oryctos is a similar species described by $\mathrm{Ng}$ (2002) from a single male $10.5 \times 12.3 \mathrm{~mm}$ collected in Guam. The most distinct character to separate both species is the ratio width/length of the carapace, being of $1.25-1.33$ in $P$. cristimanus (vs. only 1.17 in $P$. oryctos). In Mayotte specimen examined this ratio is 1.22 , almost in the range of $P$. cristimanus. Other characters indicated by $\mathrm{Ng}$ (2002) to separate both species can be sex and/or size variable and need to be appreciated with larger sets of specimens. Live coloration of $P$. cristimanus (Mayotte) and $P$. oryctos (Guam) are similar suggesting that the latter is perhaps a junior synonym of $P$. cristimanus (color photos of both species are in Legall and Poupin, 2018)

GEOGRAPHIC AND DEPTH RANGES - IWP, Mayotte (present study) to Palau, Samoa; shallow subtidal to 15-30 m (present study).

\section{Superfamily Leucosioidea Samouelle, 1819}

\section{Family Leucosiidae Samouelle, 1819}

\section{Coralliocryptus caementa Komai and Ng, 2012 (Figure 7I)}

MATERIAL EXAMINED (by Komai and Ng) - Coralliocryptus caementa Komai and Ng, 2012: 42, Mayotte KUW 2009, st. 14, 09/11/2009, 10h-12h, Bank Prudente, 12³8'50.68”'S, 4458’1.93”E, coll. J. -M. Bouchard, V. Dinhut, J. Dumas, scuba diving 15-17m, sediment suction pump, sandy bottom, coral boulders, 1 ㅇ $5.4 \times 8.8 \mathrm{~mm}$, MNHN-IU-2009-2127; st. 23, 13/11/09, 11h-13h, Pass Choizil 
'Patate à Teddy', 1240'56.91’S, 4457'51.63”'E, coll. J. -M. Bouchard, V. Dinhut, J. Dumas, scuba diving 15-30m, collapsed edge reef, $1+5.2 \times 8.3 \mathrm{~mm}$, MNHN-IU-2009-2128.

GEOGRAPHIC AND DEPTH RANGES — IWP, Mayotte to Japan, Vanuatu; 15-35m.

\section{? Hiplyra elegans (Gravier, 1920) (Figure 7J)}

MATERIAL EXAMINED - Mayotte KUW 2009, st. 26, Mutsumbatsou reef flat, intertidal at low tide, 19 juv. 4.75×4.85 mm, MNHN-IU-2013-7218.

REMARK - This small female cannot be identified with confidence by using keys with male characters in Galil (2009) and/or Naderloo and Apel (2012). Hiplyra elegans reported from Madagascar (Tuléar and Nosy Bé) is proposed with hesitation based only on resemblance with photograph in Galil (2009, fig. 7). Hiplyra variegata (Rüppell, 1830) is similar (cf. Galil, 2009, fig. 13A) and common in WIO. This too could be a possible identification for the specimen.

GEOGRAPHIC AND DEPTH RANGES - IO, ?Mayotte (present study), Madagascar to Sri Lanka; intertidal, subtidal.

Kabutos durandi (Serène, 1955) (Figure 7K)

MATERIAL EXAMINED - Mayotte KUW 2009, st. 12, La Prévoyante Reef, 6-12m, det. P. Ng, 1 ov. $2.84 \times 4.23 \mathrm{~mm}, \mathrm{MNHN}-\mathrm{IU}-2009-2129$; st. 25 , south of Islet M'tzamboro, 15-30m, 19 ov. $2.7 \times 3.8 \mathrm{~mm}$, det. J. Poupin July 2011, MNHN-IU-2013-7222.

REMARKS - This is a small species with an ovigerous female measuring $2.7 \times 3.8 \mathrm{~mm}$. It was indicated in field notes as 'Nucia sp.' corrected from photos examination by P. $\mathrm{Ng}$ (pers. comm.) as Kabutos durandi. The description and illustration of $K$. durandi are given by Komatsu and $\mathrm{Ng}$ (2011) with a diagnosis for Kabutos.

GEOGRAPHIC AND DEPTH RANGES - Mayotte (present study, first record in IO) to Philippines, Vanuatu; subtidal to $31 \mathrm{~m}$.

Nucia speciosa Dana, 1852 (Figure 7L)

MATERIAL EXAMINED - Mayotte KUW 2009, st. 25, south Islet M'tzamboro, 15-20m, 19 juv. $4 \times 5$ mm, MNHN-IU-2013-7219; st. 26, Mutsumbatsou reef flat, intertidal at low tide, 19 juv. $4.2 \times 5.1 \mathrm{~mm}$, MNHN-IU-2013-7221.

REMARKS - The carapaces of the specimens examined from Mayotte are more angular (?juvenile character) than typical Nucia speciosa and somewhat similar to Nucia rosea Nobili, 1906 from French Polynesia (photos of type specimen of N. rosea are in Legall and Poupin, 2018 and MNHN 2018, MNHN-IU-2014-7827). As Nucia speciosa is common in IWP and already reported in WIO (Réunion, Mauritius) the specimens from Mayotte are attributed to this species. Characters used to separate $N$. speciosa and $N$. rosea require revision.

GEOGRAPHIC AND DEPTH RANGES - IWP, Red Sea, Mayotte (present study) to Hawaii, French Polynesia; intertidal to subtidal and bathyal, 41-293 m (cf. Castro, 2011).

\section{Oreophorus horridus Rüppell, 1830 (Figure 7M)}

MATERIAL EXAMINED - Mayotte KUW 2009, coll. Lisa Bouchard, intertidal in rubble near the beach in front of the Dzaoudzi Airport restaurant, Petite Terre, $12^{\circ} 47^{\prime} 15.63$ 'S, $45^{\circ} 15^{\prime} 49.85^{\prime \prime} \mathrm{E}, 1 \mathrm{o}^{\Uparrow} 7.0 \times 10.0$ mm, MNHN B32264, MNHN-IU-2009-1082.

REMARKS - Specimen determined by using Tan and Ng (1995) and Galil and Innocenti (2002).

GEOGRAPHIC AND DEPTH RANGES - WIO, Red Sea, Kenya to Gulf of Aden, Mayotte (present study); intertidal. 
Urnalana elata (A. Milne-Edwards, 1873) (Figure 7N)

MATERIAL EXAMINED - Mayotte KUW 2009, st. 32, northeast Islet M'tzamboro, 6-21m, 1 9 7.1×8.4 mm, MNHN-IU-2013-7220.

OTHER RECORDS - Urnalana elata - Galil, 2005: 16, Mayotte, 47m, coll. A. Crosnier, August 1958, $1 \sigma^{\wedge}$ CL 6.0 mm, MNHN B18337; 50m, coll. A. Crosnier September 1959, 1 juv., MNHN B18714.

REMARKS - This species is closely allied to Urnalana elatula Galil, 2005 from New Caledonia. Galil (2005) indicates that females of the two species are separated by the aspect of the coxa of third maxilliped, smooth in $U$. elata (verified on Mayotte specimen) vs. bearing conical tubercles in $U$. elatula.

GEOGRAPHIC AND DEPTH RANGES — IWP, Mayotte to Japan, Marshall Islands, Samoa; intertidal to 50m.

\section{Superfamily Majoidea Samouelle, 1819}

\section{Family Epialtidae MacLeay, 1838}

\section{Huenia ?brevifrons Ward, 1941 (Figure 8A)}

MATERIAL EXAMINED - Mayotte KUW 2009, st. 17, North Reef, 22m, 1ठ 7.0×5.6 mm, MNHN B32565, MNHN-IU-2009-1325.

REMARKS - This species is associated with algae Halimeda being mimetic of its calcified green segments. The specimen from Mayotte is attributed to $H$. brevifrons with hesitation because it is distinct from typical H. brevifrons described by Griffin and Tranter (1986). The front is more rounded, with a small sub-rostral spine, and the legs are cylindrical (not carinated). The Mayotte specimen is similar to the form ' $H$. aff. brevifrons' reported by Griffin and Tranter (1986) and also to the photograph of a male from Japan in Takeda et al. (1976), identified as 'H. brevifrons'.

GEOGRAPHICAL AND DEPTH RANGES - IWP, ?Mayotte (present study, first record in WIO), Laccadives, Maldives to Japan, French Polynesia; subtidal to $22 \mathrm{~m}$.

Huenia grandidierii A. Milne-Edwards, 1865 (Figure 8B)

MATERIAL EXAMINED - Mayotte KUW 2009, coll. J. -M. Bouchard, V. Dinhut, 31 January ?2009, st. 26, Mutsumbatsou reef flat, intertidal, low tide, 2 ๙ $\widehat{~} 10.1 \times 5.9 \mathrm{~mm}, 16.2 \times 10.4 \mathrm{~mm}, \mathrm{MNHN}$ B32544, MNHN-IU-2009-1304.

REMARKS - This species is probably common in WIO although rarely reported. It has been recently collected in the Mozambique Channel at Europa and Juan de Nova (Poupin et al., 2013b; Poupin, 2016) and Réunion (Legall and Poupin, 2018). In Huenia grandidierii, as in others Huenia species, there is a strong sexual dimorphism in shape of carapace. The live coloration observed for Réunion is bright green. Huenia grandidierii is similar to Huenia pacifica Miers, 1879 distributed from Indonesia to Fiji, French Polynesia and Easter Island. Griffin and Tranter (1986: 84) indicate a few differences between these two species, sometimes considered as synonyms.

GEOGRAPHIC AND DEPTH RANGES - WIO, Somalia, Tanzania to Mayotte (present study), Réunion; intertidal to subtidal.

\section{Hyastenus uncifer Calman, 1900 (Figure 8C)}

MATERIAL EXAMINED - Mayotte KUW 2009, st. 12c, La Prévoyante Reef at night, 6-12m, 1 q 21.6 (with horns) $\times 5.9 \mathrm{~mm}, \mathrm{MNHN}$ B32558, MNHN-IU-2009-1318; st. 20b, west reef flat, Islet

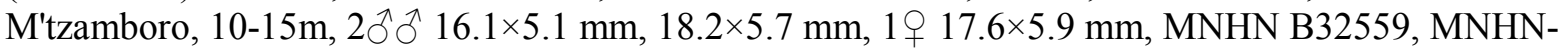
IU-2009-1319; st. 23, Pass Choizil, 'Patate à Teddy', 15-30m, 1 ^ 10.5×3.7 mm, MNHN B32560, MNHN-IU-2009-1320; st. 24, north Islet Handréma, 6-12m, 1 đ̊ 30.5×7.9 mm, MNHN B32561, MNHN-IU-2009-1321; st. 25, south Islet M'tzamboro, 15-20m, $1 \overbrace{}^{\Uparrow} 20.9 \times 5.9$ mm, MNHN B32562, MNHN-IU-2009-1322. 
REMARKS - Mayotte specimens have the characteristic long horns of the Hyastenus in the 'borradailei group': H. borradailei (Rathbun, 1907), H. brockii de Man, 1887, and H. uncifer. Hyastenus uncifer is distinct because of its long intestinal spine on posterior carapace. Hyastenus borradailei has also been reported in the region (Seychelles) by Serène (1977: 48).

GEOGRAPHIC AND DEPTH RANGES - IWP, Mozambique, Mayotte (present study) to Indonesia, Christmas Island; subtidal to $300 \mathrm{~m}$.

Lahaina incerta (Balss, 1938) (Figure 8D)

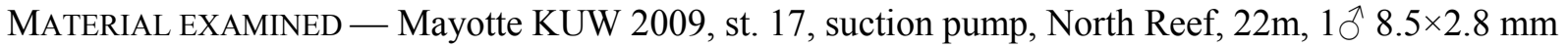
(broken; reduced spines), MNHN B32567, MNHN-IU-2009-1327; st. 25, south Islet M'tzamboro, 1520m, 1 ㅇ with Sacculina 13.9×5.3 mm, MNHN B32568, MNHN-IU-2009-1328.

REMARKS - These specimens have been determined by using key characters and figures in Griffin and Tranter (1986: 159, fig. 52a, d). The most noticeable characters are: a) spines of the carapace with small secondary rose-like spinules, distally; and b) hiatus of the upper orbit (between supraorbital eave and postorbital lobe) oval. A few differences are however observed, perhaps in the range of variation for that species: presence of a minute intercalated spine (not reported for $L$. incerta); dorsal margins of meri of ambulatory legs with 2-3 spines behind the distal spine (a single spine in H. incerta).

GEOGRAPHIC AND DEPTH RANGES - IWP, Mayotte (present study, first record in IO) to Indonesia, Marshall Islands; subtidal to $45 \mathrm{~m}$. This seems to be the first record of that species since Griffin and Tranter (1986).

Lahaina ovata Dana, 1851 (Figure 8E)

MATERIAL EXAMINED - Mayotte KUW 2009, st. 14, Bank Prudente, 15-17m, 1 q ov. $17.7 \times 7.1 \mathrm{~mm}$, MNHN B32556, MNHN-IU-2009-1316; st. 19 north Islet Handréma, 6-12m, 1 + $13.1 \times 4.9$ mm, MNHN B32557, MNHN-IU-2009-1317.

REMARKS - In this species the hiatus between the supraorbital eave and postorbital lobe is rounded with a minute spine in its middle (Griffin, 1974; Rathbun, 1906). This minute spine is not figured on the plate published for the original description (Dana, 1855, pl. 2, fig. 1).

GEOGRAPHIC AND DEPTH RANGES - IWP, Red Sea, Mayotte (present study) to Hawaii, ?French Polynesia; subtidal to 18-161m. Presence in French Polynesia with hesitation in Legall and Poupin (2018) (Marquesas, coll. 2012, AAMP Expedition, st. 21, 20m, Ua Huka, det. J. Poupin, sp. in FLMNH, UFID 030136).

\section{Menaethiops brevicornis (A. Milne-Edwards, 1868) (Figure 8F)}

MATERIAL EXAMINED - Mayotte KUW 2009, st. 26, intertidal, reef, Mutsumbatsou, 10 $5.8 \times 3.6 \mathrm{~mm}$, MNHN B32569, MNHN-IU-2009-1329.

REMARKS - Rostral horns of the specimen examined are similar to those figured by A. Milne-Edwards (1868, pl. 19, fig. 1) for a male type specimen $(8 \times 5 \mathrm{~mm})$ from Madagascar (Cap Sainte-Marie 'à une assez grande profondeur'). Its male G1, produced distally in two short triangular lobes, is typical of Menaethius species as figured by Barnard (1950, fig. 8), Guinot (1962a, fig. 2), Griffin and Tranter (1986: fig. 18g-h) and Peyrot-Clausade and Serène (1976, pl. VD). Menaethiops natalensis Barnard, photographed from Madagascar in Peyrot-Clausade and Serène (1976, pl. IC) is similar but it has a spine on the ocular peduncle, not observed on Mayotte specimen. It would have been interesting to compare the male with more specimens because characters separating M. brevicornis (Madagascar, Mayotte) with related species such as Menaethiops acutifrons (A. Milne-Edwards, 1868) (Zanzibar) and Menaethiops bicornis Alcock, 1895 (Zanzibar, Karachi) are in need of revision as these three species may be synonyms ( $c f$. Guinot, 1962a: 4).

GEOGRAPHIC AND DEPTH RANGES - WIO, ?Oman ( $c f$. Kazmi, 1997), Mayotte (present study) to Madagascar; intertidal to subtidal. 


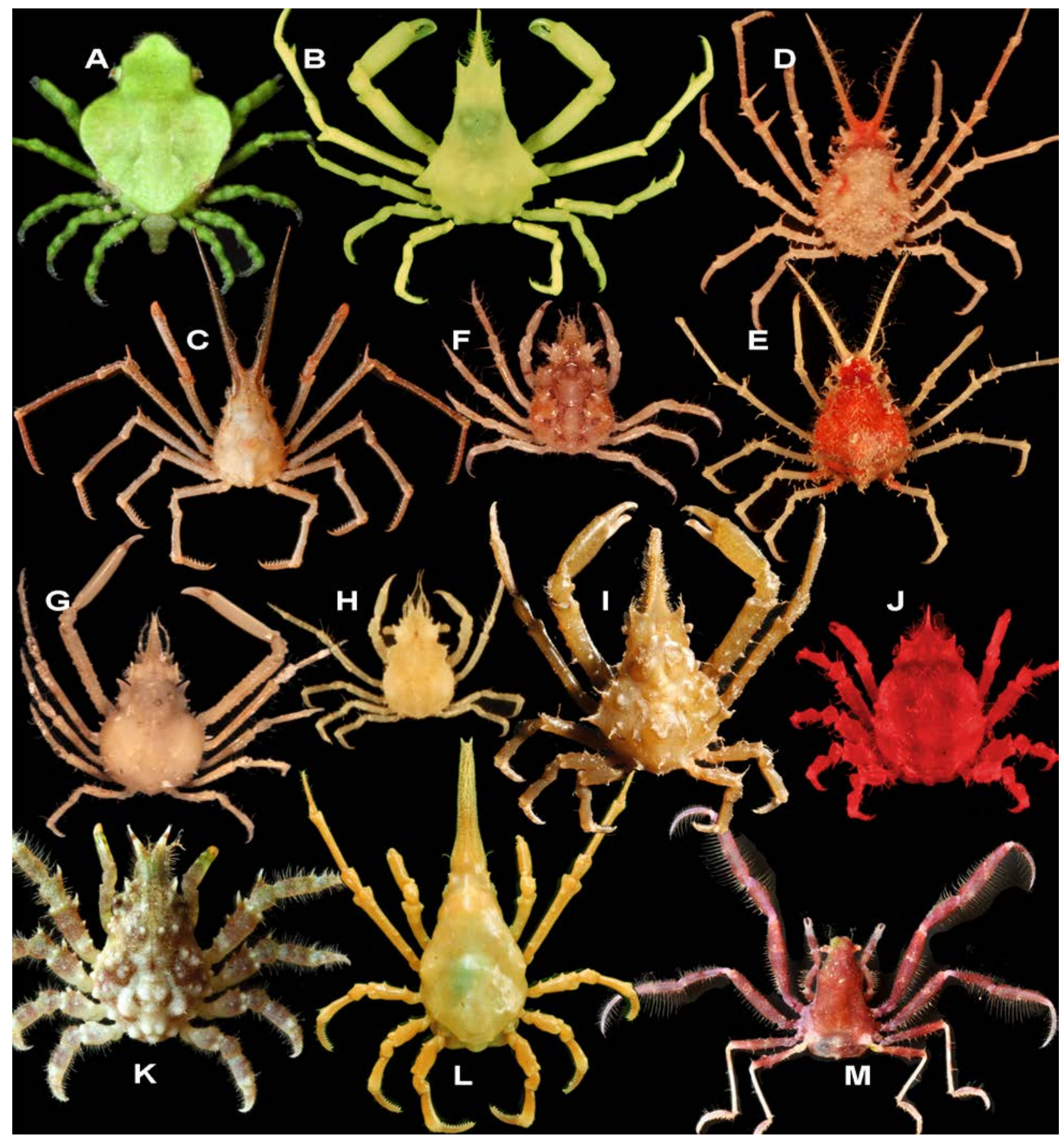

Figure 8. Crabs from Mayotte KUW 2009. Epialtidae (horns/rostrum included in carapace length)- A) Huenia ?brevifrons, $1{ }^{\lambda} 7.0 \times 5.6 \mathrm{~mm}$, MNHN-IU-2009-1325; B) H. grandidierii, $1 \overbrace{}^{\lambda} 16.2 \times 10.4 \mathrm{~mm}$, MNHN-IU-20091304 (preserved, green shade reproduced from live coloration observed at Réunion Island); C) Hyastenus uncifer, $1{ }^{\Uparrow} 30.5 \times 7.9 \mathrm{~mm}, \mathrm{MNHN}-\mathrm{IU}-2009-1321$; D) Lahaina incerta, 1 + with Sacculina $13.9 \times 5.3 \mathrm{~mm}$, MNHN-IU-20091328 (preserved); E) Lahaina ovata, 1 \% ov. $17.7 \times 7.1 \mathrm{~mm}$, MNHN-IU-2009-1316 (preserved); F) Menaethiops brevicornis, $1 \overbrace{}^{\Uparrow} 5.8 \times 3.6 \mathrm{~mm}$, MNHN-IU-2009-1329 (preserved); G) M. contiguicornis, $1 \overbrace{}^{\Uparrow} 9.3 \times 5.5 \mathrm{~mm}$, MNHNIU-2009-1311 (preserved); H) M. nodulosus, $1 \overbrace{}^{\Uparrow} 3.3 \times 1.9$ mm, MNHN-IU-2009-1326 (preserved); I) Menaethius monoceros, 1 đิ 24.6×14.2 mm, MNHN-IU-2009-1306; J) M. orientalis, 1 ㅇ ov. $8.8 \times 5.4 \mathrm{~mm}$, MNHN-IU-20091307 (preserved, red shade reproduced from live coloration observed at Glorieuses - white bands on legs omitted); K) Tylocarcinus styx, 1 ㅇ $11.3 \times 5.9 \mathrm{~mm}$, MNHN-IU-2009-1291; L) Xenocarcinus conicus, 1 ㅇ ov. $29.4 \times 10 \mathrm{~mm}$, MNHN-IU-2009-1156 (preserved). Inachidae - M) Oncinopus araneus, 1 9 9.9×6.1 mm, MNHN-IU-2009-1324. 
Menaethiops contiguicornis (Klunzinger, 1906) (Figure 8G)

Material eXAmined - Mayotte KUW 2009, st. 23, Pass Choizil, 'Patate à Teddy', 15-30m, 1 ○’ 9.3 (with horns) $\times 5.5$ mm, MNHN B32551, MNHN-IU-2009-1311; st. 26, intertidal, reef, Mutsumbatsou, 19 ov. $7.7 \times 4.6 \mathrm{~mm}, \mathrm{MNHN}$ B32552, MNHN-IU-2009-1312, coll. J. -M Bouchard, $1{ }^{\Uparrow}$ broken $14.2 \times 8.9 \mathrm{~mm}, \mathrm{MNHN}$ B32555, MNHN-IU-2009-1315 (with hesitation Menaethiops ?sp.); st. 30, Rani Reef, double barrier, 3-15m, 1 q ov. $9.25 \times 4.9$ mm, MNHN B32553, MNHN-IU-2009-1313; st. 32, northeast Islet M'tzamboro, 6-21 m, 1 ð 5.4 (horns broken) $\times 3.2 \mathrm{~mm}$, MNHN B32554, MNHN-IU2009-1314 (note - first registration of these specimens in MNHN as Menaethiops acutifrons, in error).

REMARKS - Males examined have the typical Menaethiops shaped G1, produced distally in two short triangular lobes. They were pre-identified in field notes as $M$. cf. acutifrons but corrected later into $M$. contiguicornis based on a characteristic postorbital lobe in that species, a long blunt spine. A black and white photograph of a specimen from Madagascar, attributed to M. contiguicornis with hesitation, is in Peyrot-Clausade and Serène (1976, pl. IB).

GEOGRAPHIC AND DEPTH RANGES - WIO, Red Sea, Mayotte (present study) to ?Madagascar; intertidal, subtidal $(6-21 \mathrm{~m})$.

Menaethiops nodulosus (Nobili, 1905) (Figure 8H)

MATERIAL EXAMINED - Mayotte KUW 2009, st. 17, North Reef, 22m, $1 \bigcirc 3.3 \times 1.9 \mathrm{~mm}, 1$ ov 3.1 (tips of horns broken) $\times 2.1 \mathrm{~mm}$, photo, MNHN B32566, MNHN-IU-2009-1326.

REMARKS - These two specimens were collected with suction pump in fine sediment. Despite of being small they are mature as indicated by an ovigerous female. The male G1 is typical of Menaethiops, produced distally in two short triangular lobes. The determination is based on characters and figures in Nobili (1905), Guinot (1962b), and comparison with HD photographs of type specimen in MNHNCollection (2018, MNHN-IU-2014-19858). The carapace is pyriform, uneven, with noticeable spine on the hepatic lobe; rostral horns are short, moderately divergent, the postorbital lobe is feebly serrated; there is a spine on the ocular peduncle.

GEOGRAPHIC AND DEPTH RANGES - WIO, Persian Gulf, Red Sea to Mayotte (present study), ?Réunion; subtidal to $22 \mathrm{~m}$. A specimen from Réunion has also been examined (including male G1) and attributed with hesitation to M. ?nodulosus in Poupin et al. (2013d).

Menaethius monoceros (Latreille, 1825) (Figure 8I)

MATERIAL EXAMINED - Mayotte KUW 2009, st. 6 'Déversoir Badamiers', Petite Terre, 1-3m, $2 \widehat{\jmath}$ $25 \times 15,2 \mathrm{~mm}, 24.6 \times 14.2 \mathrm{~mm}, \mathrm{MNHN}$ B32546, MNHN-IU-2009-1306, 1 q 12 (rostrum broken) $\times 7.6$ mm, MNHN B32545, MNHN-IU-2009-1305.

REMARKS - The male G1 of a Menaethius monoceros specimen from Tahiti is figured in Forest and Guinot (1961: 14, fig. 9a, b), is the same as in male specimens examined from Mayotte. Griffin and Tranter (1986) have indicated that species of Menaethius and Huenia are morphologically close which is confirmed herein for specimens of M. monoceros and $H$. grandidierii collected during Mayotte KUW 2009. Menaethius monoceros, however, is distinguished from $H$. grandidierii by: a) ventral margin of $\mathrm{P} 2$ propodus with a distal tuff of setae, without tubercle (vs. tubercle present in $H$. grandidieri); b) branchial lateral margin of the carapace lobulated (vs. more straight in $H$. grandidierii), and c) shape of carapace similar in both sexes (vs. different in $\widehat{\lambda}$ and $O$ in Huenia spp.). Live coloration and ecology are also distinct for the two species: brown and free living on the bottom overlapped with camouflage algae for M. monoceros (in situ photo for Mayotte by M. Deuss in Legall and Poupin, 2018); and bright green and probably always associated (and camouflaged) in algae Halimeda, for $H$. grandidierii.

GEOGRAPHIC AND DEPTH RANGES - IWP, Red Sea, Mayotte (present study), South Africa to Hawaii, French Polynesia; Intertidal, shallow subtidal to $83 \mathrm{~m}$. 
Menaethius orientalis (Sakai, 1969) (Figure 8J)

MATERIAL EXAMINED - Mayotte KUW 2009, st. 14, Bank Prudente, 15-17m, 2 + $94.9 \times 3.7$ mm, 7.3 (rostrum broken) $\times 4.7 \mathrm{~mm}, 2$ + 9 ov. $7.8 \times 4.9 \mathrm{~mm}, 8.8 \times 5.4 \mathrm{~mm}$, MNHN B32547, MNHN-IU-20091307; st. 17, North Reef, $22 \mathrm{~m}, 1{ }^{\top} 3.5 \times 2.0 \mathrm{~mm}, 1$ + ov. $7.3 \times 4.5 \mathrm{~mm}$, MNHN B32548, MNHN-IU2009-1308; st. 30, Rani Reef double barrier, 3-15m, 1 § 8.1×5.2 mm, MNHN B32549, MNHN-IU2009-1309; st. 35, Surprise Reef, Pass Longoni-M’tzamboro, 4-25m, $1 \overbrace{}^{\lambda} 8.7 \times 5.3 \mathrm{~mm}, 1$ 우 ov. 8.1×5.1 mm, MNHN B32550, MNHN-IU-2009-1310.

OTHER RECORDS - Poupin et al., 2013c: 11, Glorieuses.

REMARKS - Male G1 of specimens examined match that figured for M. orientalis in Griffin and Tranter (1986: 69, fig. 18c, d). Menaethius orientalis is distinguished from M. monoceros by: a) a shorter rostrum; b) presence of carinae on legs (vs. absent in M. monoceros); and c) live coloration bright red on carapace with ambulatory legs banded in red and white (photos of live specimens from Glorieuses and Moorea in Legall and Poupin, 2018) (vs. brown in M. monoceros).

GEOGRAPHIC AND DEPTH RANGES - IWP, Red Sea, Mayotte (present study) to Japan, French Polynesia; subtidal to $54 \mathrm{~m}$.

\section{Tylocarcinus styx (Herbst, 1803) (Figure 8K)}

MAterial EXAMINED - Mayotte KUW 2009, st. 12, La Prévoyante Reef, 6-11m, 1 đ juv. $4.9 \times 2.3$ mm, MNHN B32534, MNHN-IU-2009-1294; st. 14, Bank Prudente, 15-17m, $1 \overbrace{}^{\Uparrow} 8.15 \times 4.4 \mathrm{~mm}$ (horns

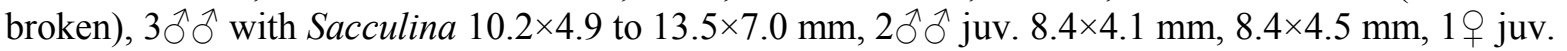
7.2×3.6 mm MNHN B32533, MNHN-IU-2009-1293; st. 26, intertidal low tide, Mutsumbatsou reef flat, 1 q $11.3 \times 5.9 \mathrm{~mm}$, MNHN B32531, MNHN-IU-2009-1291, 1 đ $13.2 \times 7.1 \mathrm{~mm}, 1$ 우 $10.8 \times 5.7 \mathrm{~mm}$, MNHN B32532, MNHN-IU-2009-1292.

OTHERS RECORDS - Poupin et al., 2013c: 11, Glorieuses.

REMARKS - Male G1 of this species is figured in Guinot (1962c: 240, fig. 17a, b) showing a triangular distal lobe. Tylocarcinus styx is rather polymorphic, especially for length of fused part of the horns or live coloration with variable shades of green, red, brown or pink. A character rather constant, however, and useful to quickly recognized this crab on the reef is the 'skull-shaped' design on posterior carapace.

GEOGRAPHIC AND DEPTH RANGES — IWP, Red Sea, Mayotte (present study) to Japan, French Polynesia; intertidal to subtidal.

Xenocarcinus conicus (A. Milne-Edwards, 1865) (Figure 8L)

MATERIAl EXAMINED - Mayotte KUW 2009, st. 37, Islet Mbouzi 'Patate sud-est', 3m, coll. J. -M. Bouchard 10 August 2007, 1 ov. 29.4×10 mm, MNHN B32383, MNHN-IU-2009-1156.

REMARKS - This specimen was collected on a black coral Antipathes dichotoma by J. -M. Bouchard two years before KUW fieldwork. It has been added to the KUW collection and determined by using characters and drawings in Griffin and Tranter (1986).

GEOGRAPHICAL AND DEPTH RANGES - IWP, Red Sea, Mayotte (present study) to Japan, Indonesia; subtidal to $80 \mathrm{~m}$.

\section{Family Inachidae MacLeay, 1838}

\section{Oncinopus araneus (De Haan, 1839) (Figure 8M)}

MATERIAL EXAMINED - Mayotte KUW 2009, st. 21b, east Islet Choizil, Malandzamiayatsini, 15-20m, 1 우 (remains of eggs laid recently) $5.8 \times 3.3 \mathrm{~mm}, \mathrm{MNHN}$ B32563, MNHN-IU-2009-1323; st. 24, north Islet Handréma, 6-12m, 9.9×6.1 mm, MNHN B32564, MNHN-IU-2009-1324.

GEOGRAPHIC AND DEPTH RANGES - IWP, Mayotte (present study), Seychelles, Maldives, Laccadives to Japan, Hawaii, French Polynesia; shallow subtidal to bathyal, 16-400m. 


\section{Family Majidae Samouelle, 1819}

Cyclax spinicinctus Heller, 1861 (Figure 9A)

MATERIAL EXAMINED - Mayotte KUW 2009, coll. J. -M. Bouchard st. Mliha 11, near st. 26, intertidal, reef, Mutsumbatsou, 19 juv. 11.2×8.2 mm, MNHN B32535, MNHN-IU-2009-1295.

REMARKS - A photograph of this species with drawings of the orbital region is in Forest and Guinot (1961, pl. VI, fig. 3; fig. 7, 8). Cyclax spinicinctus is affiliated to C. suborbicularis (Stimpson, 1858) with characters separating them in Forest and Guinot (1961: 15).

GEOGRAPHIC AND DEPTH RANGES - IWP, Red Sea, Kenya, Mayotte (present study) to Japan, Samoa; shallow subtidal.

Micippa platipes Rüppell, 1830 (Figure 9B)

MATERIAL EXAMINED - Mayotte KUW 2009, st. 6, 'Déversoir Badamiers', Petite Terre, intertidal to 3m, 1 ð 20.5×17.2 mm, MNHN B32528, MNHN-IU-2009-1288; coll. J. -M. Bouchard 31/01/2009?, st. Mliha, near st. 26, intertidal, reef, Mutsumbatsou, under rubble, $1 \overbrace{}^{\Uparrow} 14.5 \times 11.25 \mathrm{~mm}$, MNHN B32527, MNHN-IU-2009-1287.

REMARKS - Micippa platipes can be confused with Micippa philyra (Herbst, 1803). The two species were for a long time considered as synonyms until Buitendijk (1939: 34) indicated their differences. Mayotte specimens are attributed to M. platipes because of: a) basal antennal segment almost smooth; b) orbit open ventrally and U-shaped between margin of basal antennal segment and postorbital lobe;

c) anterolateral margins of carapace with 8-9 spines; and d) distal tip of male G1 straight.

GEOGRAPHIC AND DEPTH RANGES - IWP, Persian Gulf, Mayotte (present study), South Africa to Japan, Tonga; intertidal, subtidal.

Micippa thalia (Herbst, 1803) (Figure 9C)

MATERIAL EXAMINED - Mayotte KUW 2009, coll. J. -M. Bouchard ? 31/01/2009, st. Mliha, near st. 26, under rubble, intertidal, reef, Mutsumbatsou, 1 q juv. 7.5×5.3 mm ; MNHN B32529, MNHN-IU-20091289; st. 26, 1 q ov. $19.1 \times 14$ mm, MNHN B32530, MNHN-IU-2009-1290.

REMARKS - The specimens examined match well the photograph of M. thalia type specimen in Sakai, 1999: pl. 13E), especially for the aspect of the anterolateral margin of the carapace. They are distinct from Micippa platipes, collected at the same station (st. 26), by the absence of lateral horns on rostral spines ( $c f$. key of Micippa in Griffin and Tranter, 1986: 274). The specimens examined are also similar to Micippa xishaensis Chen, 1979 (known from a single male) for: a) spines on anterolateral margin of carapace reduced to granules; b) postorbital lobe with a large lobe on posterior margin basally; and c) basal antennal segment smooth with a distinct spine at anteromesial angle. Micippa thalia is widely distributed in IWP and already reported from Madagascar. Reporting the specimens from Mayotte as M. thalia seems logical but the differences between this species and M. xishaensis are in need of revision when more specimens of the latter are available.

GEOGRAPHIC AND DEPTH RANGES - Red Sea, Mayotte (present study), South Africa to Japan, northeastern Australia; intertidal to $100 \mathrm{~m}$.

Schizophrys aspera (H. Milne Edwards, 1834) (Figure 9D)

MATERIAL EXAMINED - Mayotte KUW 2009, st 3a, fringing reef, Trévani, 1-8m, 1 juv. 10.5×6.8 mm, MNHN B32537, MNHN-IU-2009-1297; st. 20b, western reef, Islet M'tzamboro, 10-15m, $1 \delta^{\lambda}$ $21.5 \times 16.0 \mathrm{~mm}, \mathrm{MNHN}$ B32542, MNHN-IU-2009-1302; st. 21b, Islet Choizil, east of

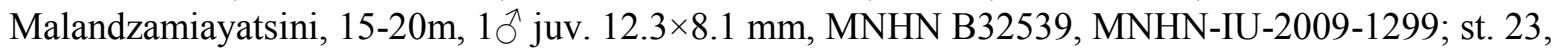

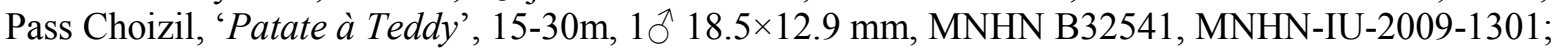
st. 24, north Islet Handréma, 6-12m, 1 + ov. $29 \times 24 \mathrm{~mm}$ (without horns), MNHN B32416, MNHN-IU2009-1178; st. 25, southern tip, Islet M'tzamboro, 15-20m, $2 \hat{\jmath}$ o $16.3 \times 11.4 \mathrm{~mm}, 18.8 \times 13.4 \mathrm{~mm}, 1$ ㅇ ov. 17.8 $\times 13.8$ mm, MNHN B32540, MNHN-IU-2009-1300; st. 26, intertidal, Mutsumbatsou reef flat, 
2 우 juv. 9,5 (rostral horns included) $\times 6.5 \mathrm{~mm}, 13.4 \times 9.2 \mathrm{~mm}$, MNHN B32536, MNHN-IU-20091296; st. 28, east Islet Mbouini, 3-20m, 10 17 17.2×12.9 mm, MNHN B32543, MNHN-IU-2009-1303;

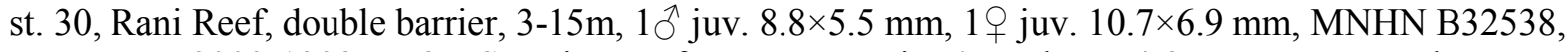
MNHN-IU-2009-1298; st. 35, Surprise Reef, Pass Longoni-M'tzamboro, 4-25m, carapace only, reported in field notes, not collected.

REMARKS - The specimens collected include several juveniles mixed with much larger material which makes it possible to appreciate morphological variations with size. In juveniles the granulation of the carapace is reduced and the distal end of male G1 is little or not curved. In adults rostral horns can

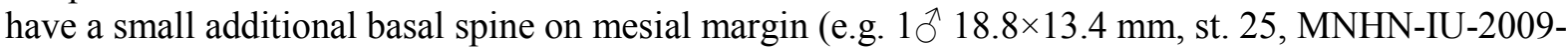
1300). These size-related morphological variations have been noted for $S$. aspera by A. MilneEdwards (1872) after examining many specimens from New Caledonia.

GEOGRAPHIC AND DEPTH RANGES - IWP, Red Sea, Mayotte (present study), South Africa to Hawaii, French Polynesia; intertidal to $69 \mathrm{~m}$.

\section{Superfamily Parthenopoidea MacLeay, 1838}

\section{Family Parthenopidae MacLeay, 1838}

\section{Daldorfia leprosa (Nobili, 1905) (Figure 9F)}

MATERIAL EXAMINED - Mayotte KUW 2009, st. 23, Pass Choizil, 'Patate à Teddy', 15-30m, 10 $13 \times 17.4 \mathrm{~mm}, \mathrm{MNHN}$ B32424, MNHN-IU-2009-1186; st. 25, Islet M'tzamboro, southern tip, 15-20m, 1 ภ $16 \times 22$ mm, 1 juv. $6.4 \times 8.5$ mm, MNHN B32425, MNHN-IU-2009-1187.

REMARKS - These specimens were determined by using characters in Tan and $\mathrm{Ng}$ (2007). Sternal pit in male is deep with a reticulated pattern, this pattern being reduced in the largest specimen $(\widehat{\delta} 16 \times 22$ mm, MNHN-IU-2009-1187).

GEOGRAPHIC AND DEPTH RANGES — Red Sea, Mayotte (present study), Madagascar to Japan, French Polynesia; intertidal to $30 \mathrm{~m}$.

\section{Daldorfia rathbunae (De Man, 1902) (Figure 9G)}

MATERIAL EXAMINED - Mayotte KUW 2009, st. 35, Surprise Reef, Pass Longoni-M'tzamboro, 4-25m, 1 juv. 7.2×9.4 mm, MNHN B32426, MNHN-IU-2009-1188.

REMARKS - This juvenile is attributed to Daldorfia rathbunae because of the ' $r$-shaped' spines on dorsal margin of ambulatory legs. The sternal pit is divided into three, a small anterior pit plus two lateral posterior pits (see Tan and $\mathrm{Ng}, 2007: 148$ ).

GEOGRAPHIC AND DEPTH RANGES - Mayotte (present study, westernmost limit in WIO), Madagascar to Japan, Hawaii, New Caledonia.

\section{Lambrachaeus ramifer Alcock, 1895}

MATERIAL EXAMINED - Mayotte KUW 2009, coll. J. -M. Bouchard, 2010-2012, lagoon, scuba dive, 5$10 \mathrm{~m}$, preserved specimen det. Poupin/Guinot in Paris MNHN 9 July 2012. Specimen indicated in draft notes but not located in MNHN collection.

REMARKS - This specimen must be in MNHN, probably unregistered as it is not indicated the catalog (MNHN-Collection 2018, Parthenopidae from Mayotte). A living specimen of L. ramifer was photographed from Réunion in Legall and Poupin (2018). Ng and McLay (2003) can be consulted for redescription of this species, its geographic distribution and its transfer from Majidae to Parthenopidae.

GEOGRAPHIC AND DEPTH RANGES — Red Sea, Mayotte (present study), South Africa to Japan, Hawaii; subtidal to $54-92 \mathrm{~m}$. 


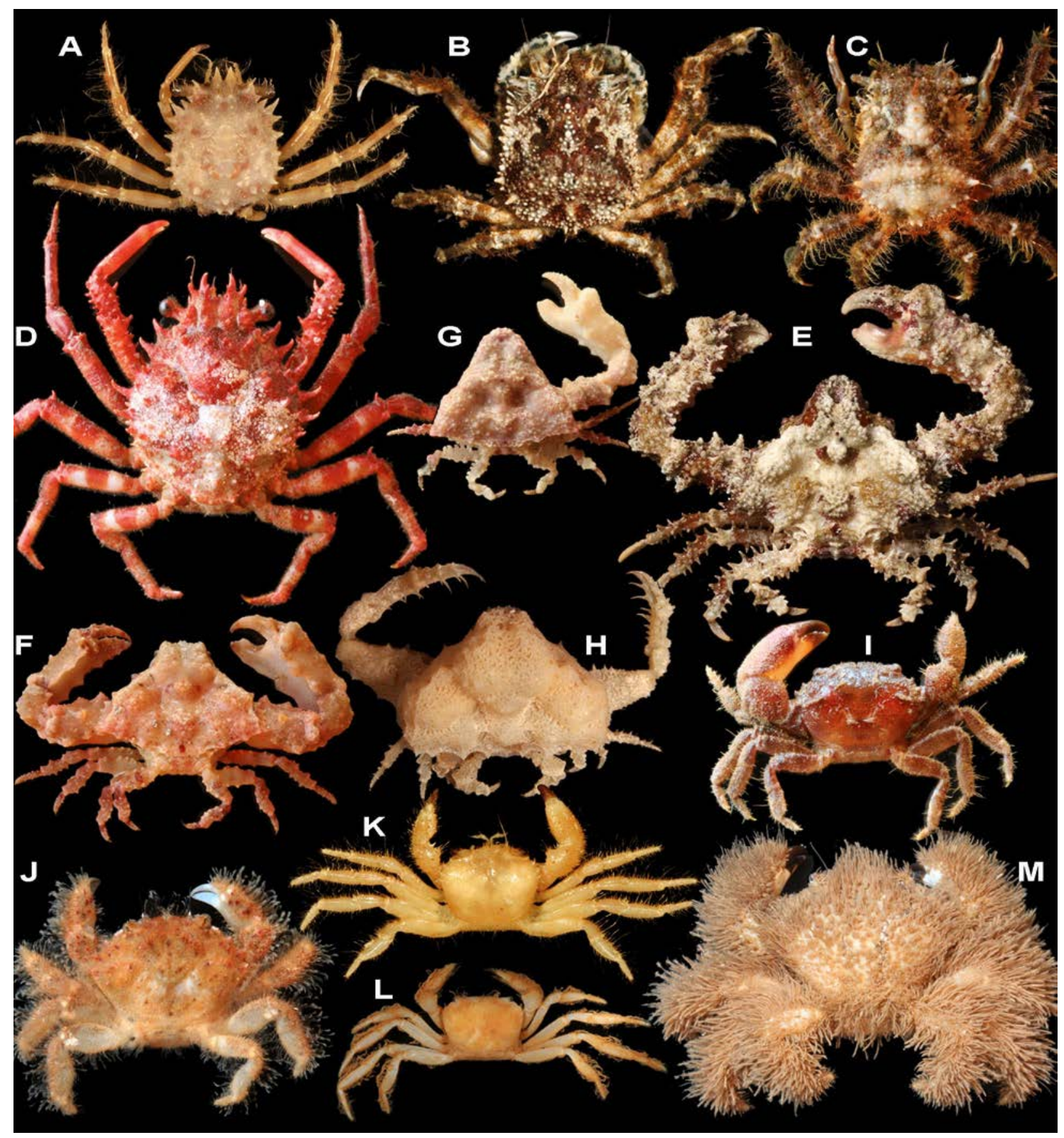

Figure 9. Crabs from Mayotte KUW 2009. Majidae - A) Cyclax spinicinctus, 1 juv. $11.2 \times 8.2 \mathrm{~mm}$, MNHN-IU-2009-1295; B) Micippa platipes, 1 त 20.5×17.2 mm, MNHN-IU-2009-1288; C) M. thalia, 1 ㅇ ov. $19.1 \times 14 \mathrm{~mm}$, MNHN-IU-2009-1290; D) Schizophrys aspera, 1 q ov. 29 (without horns) $\times 24 \mathrm{~mm}$, MNHN-IU-2009-1178. Parthenopidae - E) Daldorfia horrida, $1 \hat{O}^{\lambda}$, from Glorieuses, coll. Poupin 13.12.2012, not measured, approximately $38 \times 40 \mathrm{~mm}$, MNHN-IU-2013-7341; F) D. leprosa, $1 \hat{\jmath} 13 \times 17.4$ mm, MNHN-IU-2009-1186; G) D. rathbunae, 1 juv. 7.2×9.4 mm, MNHN-IU-2009-1188; H) Thyrolambrus efflorescens, $1 \curvearrowright 8 \times 12 \mathrm{~mm}$, MNHN-IU-2013-7226. Pilumnidae - I) Glabropilumnus laevimanus, $1 \delta^{\top} 6.2 \times 9.0 \mathrm{~mm}$, MNHN-IU-2013-7227; J) Pilumnus ?fissifrons, 1 + $6.8 \times 10 \mathrm{~mm}$, MNHN-

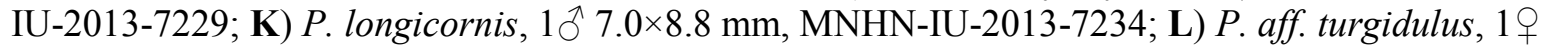
$3.4 \times 4.7 \mathrm{~mm}, \mathrm{MNHN}-\mathrm{IU}-2013-7232$; M) P. vespertilio, 1 ㅇ ov. $16.4 \times 21 \mathrm{~mm}$, MNHN-IU-2009-1226. 
Thyrolambrus efflorescens (Alcock, 1895) (Figure 9H)

MATERIAL EXAMINED - Mayotte KUW 2009, coll. J. -M. Bouchard, 2008-2011, 1ठ̂ 8×12 mm, MNHNIU-2013-7226.

REMARKS - A key to Thyrolambrus species, with photographs, is in Tan and Ng (2007). Thyrolambrus efflorescens is similar to WA T. astroides Rathbun, 1894.

GEOGRAPHIC AND DEPTH RANGES - Mayotte (present study, westernmost limit in WIO), Mauritius to Guam, French Polynesia; subtidal to $66 \mathrm{~m}$.

\section{Superfamily Pilumnoidea Samouelle, 1819}

\section{Family Pilumnidae Samouelle, 1819}

\section{Glabropilumnus laevimanus (Dana, 1852) (Figure 9I)}

MATERIAL EXAMINED - Mayotte KUW 2009, st. 10, east Islet 'Quatre frères, Vatou', intertidal, $2 \hat{\jmath} \widehat{o}$ $5.9 \times 8.6 \mathrm{~mm}, 6.2 \times 9.0 \mathrm{~mm}, 1$ ㅇ $5.4 \times 7.9 \mathrm{~mm}, 5$ त ${ }^{\lambda} 4.6 \times 6.6$ to $5.0 \times 7.0 \mathrm{~mm}, 2$ 우 $4.5 \times 6.2 \mathrm{~mm}, 5.2 \times 7.2$ mm, MNHN-IU-2013-7227; st. 26c, Mutsumbatsou reef flat, coll. J. -M Bouchard 03/08/2008, 1 juv. 4.6×6.6 mm, MNHN-IU-2013-7228; st. 29, intertidal, beach, Mboianatsa, Ngouja Hotel, 1 9 3.6 $\times 5.0$ $\mathrm{mm}, \mathrm{MNHN}-\mathrm{IU}-2013-7230$.

Remarks - These specimens are attributed to Glabropilumnus laevimanus according to diagnosis in Galil and Takeda (1988). Most of the characters of G. laevimanus are validated except 'upper margins of pereiopodal meri 2-4 carinate', these margins being at most angular in specimens examined.

GEOGRAPHIC AND DEPTH RANGES - IWP, Red Sea, Tanzania (Zanzibar), Mayotte (present study) to China sea, New Caledonia; intertidal, subtidal.

Latopilumnus malardi (de Man, 1914) (Figure 19H-J)

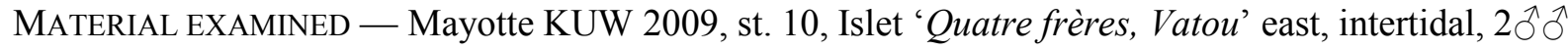
$4.5 \times 6.2 \mathrm{~mm}, 5.3 \times 7.2 \mathrm{~mm}, \mathrm{MNHN}-\mathrm{IU}-2013-7236$, det. P. K. L. Ng (from photos, 2017).

REMARKS - These specimens were pre-determined in field notes as Pilumnus sp. B (J. Poupin, July 2011). They were determined by P.K.L. Ng (from photographs) during the redaction of this contribution. Characters identifying L. malardi are in Ng and Clark (2008); a revision of genera Latopilumnus Türkay and Schuhmacher, 1985 and Aniptumnus Ng, 2002. In Mayotte specimens the G1 is distally hooked, a character that separates them from related L. conicus where this part is not curved (compare $\mathrm{Ng}$ and Clark, 2008, figs 4e-f and 8d-e). Latopilumnus malardi is also close to $L$. truncatospinosus (de Man, 1914), but distinct by the aspect of its anterolateral teeth of carapace, less pointed than in L. truncatospinosus, and granules on carpus and chela of chelipeds, pearl-like in (vs. conic and truncated in L. truncatospinosus; compare $\mathrm{Ng}$ and Clark, 2008, figs 4a, c-d and 5a, g-i). Aniptumnus vietnamicus $\mathrm{Ng}$ and Clark, 2008 is another related species, similar to L. malardi for distal aspect of male G1 (several specimens from Vietnam attributed by Raoul Serène to 'Parapilumnus malardi' have been assigned to A. vietnamicus by $\mathrm{Ng}$ and Clark (2008).

GEOGRAPHIC AND DEPTH RANGES — WIO (?IWP), Mayotte (present study), Madagascar (type locality); intertidal, subtidal. This species is probably widespread in IWP although rarely reported. It is invasive in the Levantine Sea and in the English Channel (but not established there). De Man $(1913,1914)$ has described this crab from specimens collected between barnacles fixed on ship hull mooring at SaintVaast-la-Hougue, English Channel, coming from Madagascar. The record in the Levantine sea is indicated as 'from Türkay, 2015, personal database' in WoRMS (2018). 
Pilumnus ?fissifrons Stimpson, 1858 (Figure 9J)

MATERIAL EXAMINED - Mayotte KUW 2009, st. 19, north Islet Handréma, 6-10m, 1 q 6.8×10 mm, MNHN-IU-2013-7229.

REMARKS - Pilumnus fissifrons is known with certainty only from Australia. This determination is proposed with hesitation from key and diagnosis in Takeda and Miyake (1968) but without reference to comparative material. Characters verified are: shape of carapace, pilosity, and characteristic slopping front with marked median fissure.

GEOGRAPHIC AND DEPTH RANGES - ?IWP, ?Mayotte (present study, first record in WIO) and Australia (western and eastern); subtidal (6-10 m).

Pilumnus longicornis Hilgendorf, 1878 (Figure 9K)

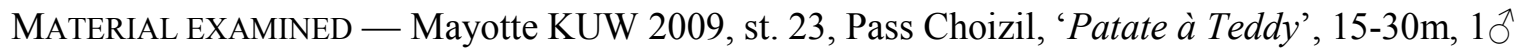
$7.0 \times 8.8 \mathrm{~mm}, 1$ juv., 1 $4.6 \times 5.8 \mathrm{~mm}$, MNHN-IU-2013-7234.

OTHER RECORDS - Pilumnus ?longicornis - Poupin et al., 2013c: 11, Glorieuses (1 sp. MNHN-IU-20137356).

REMARKS - Mayotte specimens were determined using Sakai (2004) and verification of male G1 from Takeda and Miyake (1968: 51, fig. 13 d-f), however no comparative material were examined. These small crabs superficially resemble Eupilumnus calmani and Glabropilumnus laevimanus and were mixed with these species before sorting.

GEOGRAPHIC AND DEPTH RANGES — IWP, Mozambique, Mayotte (present study), South Africa to Hawaii, Tuvalu; subtidal to $85 \mathrm{~m}$.

Pilumnus aff turgidulus Rathbun, 1911 (Figure 9L)

MATERIAL EXAMINED — Mayotte KUW 2009, st. 19, Islet Handréma north, 6-10m, 1 q 3.4×4.7 mm, MNHN-IU-2013-7232.

REMARKS - This specimen has only superficial resemblances with the photograph of Pilumnus turgidulus in Rathbun (1911, pl. 19, fig. 1) but is not considered to be her species.

GEOGRAPHIC AND DEPTH RANGES - Mayotte (present study), 6-10m.

Pilumnus vespertilio (Fabricius, 1793) (Figure 9M)

MATERIAL EXAMINED - Mayotte KUW 2009, st. 2, littoral Trévani beach to Kangani Mangrove, 2 q $q$ $6.0 \times 8.3 \mathrm{~mm}, 10.5 \times 15.0 \mathrm{~mm}, \mathrm{MNHN}$ B32296, MNHN-IU-2009-1114; st. 6, 'Déversoir Badamiers', Petite Terre, intertidal, 4 juv. $4.5 \times 6$ to $8.4 \times 10.6 \mathrm{~mm}$, MNHN-IU-2013-7231; st. 10, east Islet 'Quatre frères, Vatou', littoral, 1 o ov. $16.4 \times 21 \mathrm{~mm}, 4$ ov., 1 ㅇ, $1{ }^{\Uparrow}, 1$ juv, MNHN B32464, MNHN-IU-20091226; st. 26, intertidal, Mutsumbatsou reef flat, $1 \sigma^{\top} 15.5 \times 21$ mm, MNHN B32463, MNHN-IU-20091225; st. 38, southwest Chiconi/Sada bay, coll. J. -M. Bouchard, intertidal, 24 July 2008, 3 ऊิ $\widehat{o} 6.0 \times 8.5$ to $11.8 \times 16.5 \mathrm{~mm}, 1$ + ov. $8.0 \times 11.0 \mathrm{~mm}, \mathrm{MNHN}$ B32295, MNHN-IU-2009-1113.

OTHER RECORDS - Guinot, 1958c: 278, Mayotte, 1 ð 6×4.7 mm, MNHN.

GEOGRAPHIC AND DEPTH RANGES - IWP, Mozambique, South Africa to Hawaii, Wallis and Futuna; intertidal, subtidal. 


\section{Superfamily Portunoidea Rafinesque, 1815}

\section{Family Portunidae Rafinesque, 1815}

Catoptrus rathbunae Serène, 1966 (Figure 10A)

MATERIAL EXAMINED - Mayotte KUW 2009, st. 27, Islet Mbouzi 'Patate sud-est', 4-20m, 2 우 4.3×5.8 $\mathrm{mm}, 5.3 \times 7.3 \mathrm{~mm}, \mathrm{MNHN}$ B32521, MNHN-IU-2009-1281; st. 28, east Islet Mbouini, 3-20m, $1 \delta^{\lambda}$

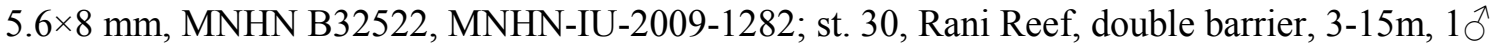
$4.9 \times 6.9$ mm, MNHN B32523, MNHN-IU-2009-1283; st. 35, Surprise Reef, Pass Longoni-

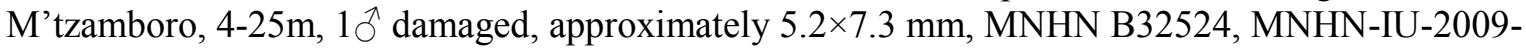
1284.

REMARKS - In field notes these specimens were erroneously labeled as 'C. nitidus'. Vannini and Innocenti (2000: 257, fig. 8-9) were consulted for differences between C. rathbunae and C. nitidus, including figures of male G1.

GEOGRAPHIC AND DEPTH RANGES — IWP, Somalia, Mayotte (present study) to Vietnam; subtidal, 3$25 \mathrm{~m}$.

Charybdis anisodon (De Haan, 1850) (Figure 10B)

MATERIAL EXAMINED - Mayotte KUW 2009, st. 16, Longoni Bay, traps 2m, in front of mangrove, $1 \hat{\jmath}$ $26 \times 48.5 \mathrm{~mm}$ (with lateral spine), MNHN B32476, MNHN-IU-2009-1238.

GEOGRAPHIC AND DEPTH RANGES - IWP, Red Sea, Mayotte (present study), Madagascar to Philippines, New Caledonia; subtidal to $37 \mathrm{~m}$.

Gonioinfradens paucidentatus (A. Milne-Edwards, 1861) (Figure 10F)

MATERIAL EXAMINED - Mayotte KUW 2009, st. 14, Bank Prudente, 15-17m, 1 juv. 10.3×13.4 mm, 1 juv., MNHN B32472, MNHN-IU-2009-1234; st. 22, west Islet Choizil, Malandzamiayajou, traps 3035m, 1 ㅇ 31×39.4 mm, 1 ㅇ ov., MNHN B32473, MNHN-IU-2009-1235; st. 32, northeast Islet M'tzamboro, 6-21m, 1 juv. 5.6 $\times 7.5 \mathrm{~mm}$ (with a doubt, a juvenile of another species possible), MNHN B32517, MNHN-IU-2009-1277; st. 34, Beach 'du Préfet', 2-8m, 19 ov. 34×46 mm, MNHN B32471, MNHN-IU-2009-1233.

REMARKS - Gonioinfradens paucidentatus has only 4 spines on the anterolateral margin of carapace with 2 additional smaller intercalated spines between spines 1-2 and 2-3. Other characters of specimens examined are those recapitulated in Apel and Spiridonov (1998). Gonioinfradens is a monotypic genus.

GEOGRAPHIC AND DEPTH RANGES - Red Sea, Kenya, Mayotte (present study) to Japan, French Polynesia; subtidal to $150-300 \mathrm{~m}$.

Laleonectes nipponensis (Sakai, 1938) (Figure 10G)

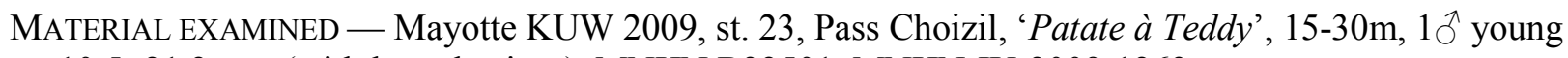
$10.5 \times 21.2 \mathrm{~mm}$ (with lateral spines), MNHN B32501, MNHN-IU-2009-1263.

REMARKS - This specimen has a stridulating apparatus composed of ridges situated on the pterygostomian area and merus of cheliped. Crosnier and Moosa (2002) have reviewed four Portunidae species with such a stridulating apparatus and Mendoza and Devi (2017) have described an additional species from Réunion and southwestern coast of India, at depths of 100-250m. Mayotte specimen has juvenile characters and is tentatively attributed to Laleonectes nipponensis based on the shape of male G1, fresh color pattern, and P2 and P3 meri clearly overreaching distal end of P1 merus (in L. kuriya Mendoza and Devi, 2017, P2 and P3 do not overreach distal P1 merus).

GEOGRAPHIC AND DEPTH RANGES - Mayotte (present study, single confirmed record in WIO) to Japan, French Polynesia; subtidal to $130 \mathrm{~m}$. 


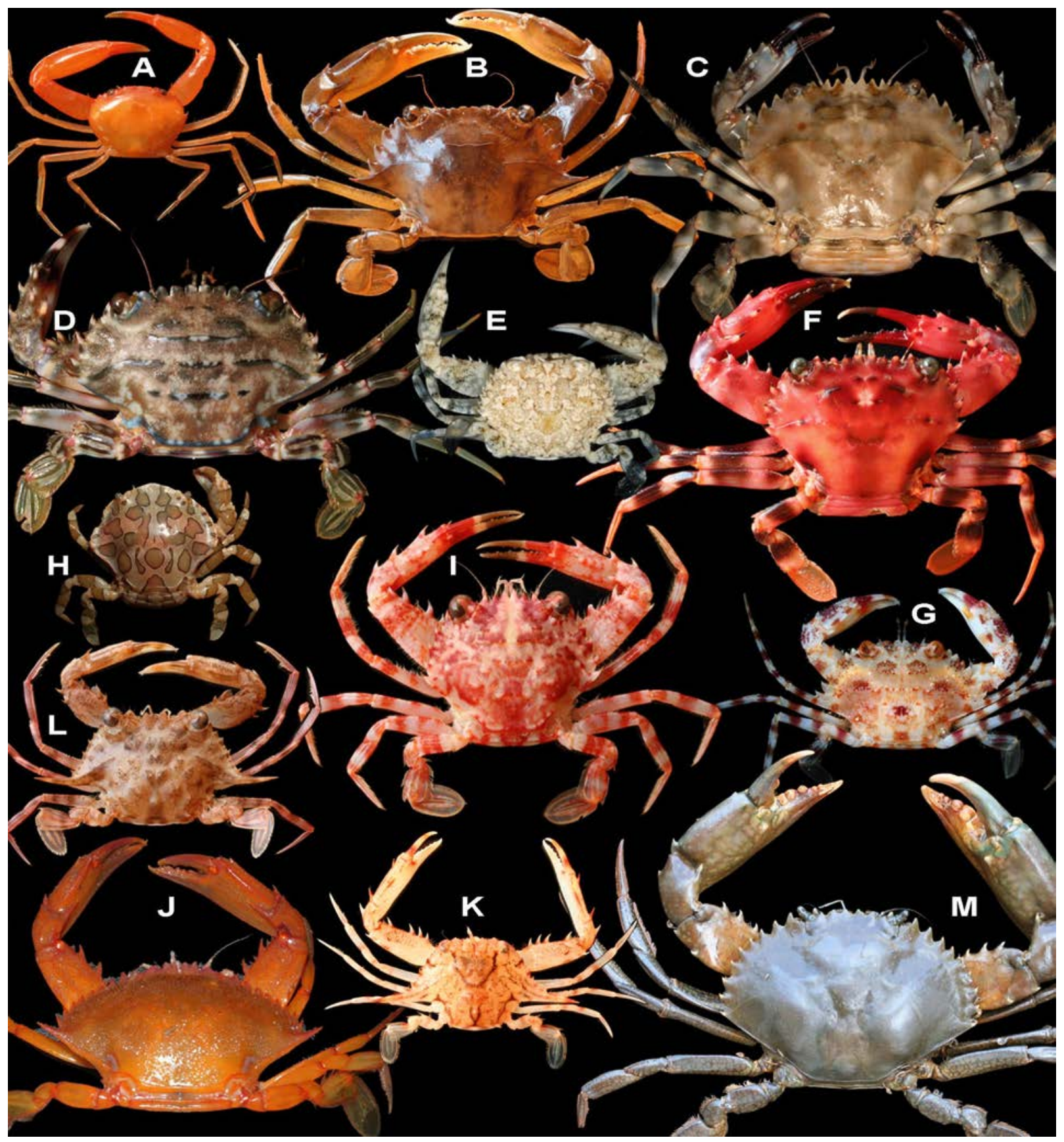

Figure 10. Crabs from Mayotte KUW 2009. Portunidae - A) Catoptrus rathbunae, $1 \overbrace{}^{\Uparrow} 5.6 \times 8 \mathrm{~mm}$, MNHN-IU-2009-1282; B) Charybdis anisodon, $10^{\Uparrow} 26 \times 48.5 \mathrm{~mm}$ (with lateral spine), MNHN-IU-20091238; C) C. annulata, 1 ㅇ ov. $40 \times 56 \mathrm{~mm}$, MNHN-IU-2013-7313 (Glorieuses 2012); D) Charybdis obtusifrons, 19 about $30 \times 45 \mathrm{~mm}$ (Glorieuses 2012, not collected); E) Cycloachelous granulatus, Glorieuses, 1 sp. MEPA1248 about $15 \times 20 \mathrm{~mm}$, not located in FLMNH collection, photo M. Malay; F) Gonioinfradens paucidentatus, 1 ㅇ ov. $34 \times 46$ mm, MNHN-IU-2009-1233; G) Laleonectes nipponensis, $1{ }^{\lambda}$ young $10.5 \times 21.2 \mathrm{~mm}$ (with spines), MNHN-IU-2009-1263; H) Lissocarcinus orbicularis, 1 우 $14.4 \times 16.7 \mathrm{~mm}, \mathrm{MNHN}-\mathrm{IU}-2009-1185$; I) Lupocyclus quinquedentatus, $1 \overbrace{}^{\Uparrow} 18.2 \times 23.5 \mathrm{~mm}$, MNHN-IU2009-1264; J) Portunus convexus, $1 \mathrm{sp}$. not measured, about $30 \times 66 \mathrm{~mm}$ (with spines), not in MNHN collection (photo C. Hily); K) P. (Xiphonectes) cf. longispinosus, 1 § $15.5 \times 36 \mathrm{~mm}$ (with lateral spines), MNHN-IU-2009-1258; L) P. mariei, $1 \overbrace{}^{\Uparrow} 13.8 \times 30.8 \mathrm{~mm}$ (with lateral spines), MNHN-IU-2009-1254; M) Scylla serrata, 1 đิ $93.6 \times 140 \mathrm{~mm}$ (not kept for MNHN collection because very large size). 
Lissocarcinus orbicularis Dana, 1852 (Figure 10H)

MATERIAL EXAMINED - Mayotte KUW 2009, st. 8, lagoon near Great North East Reef, 6-8m, 1 ภ 6.6×7.6 mm, MNHN B32422, MNHN-IU-2009-1184; st. 12, La Prévoyante Reef, 6-11m, 1 q $14.4 \times 16.7 \mathrm{~mm}, \mathrm{MNHN}$ B32423, MNHN-IU-2009-1185; st. 15, northeastern beach, Islet M'tzamboro, 0-3m, 1 ठै 4.5×4.8 mm, MNHN B32421, MNHN-IU-2009-1183.

OTHER RECORDS - Crosnier, 1962: 25, Mayotte. - Guinot, 1967b: 250, list with Mayotte. - Coll. Anker and Michonneau, 2008, Mayotte st. MAY08-St5, reef, S-shaped Pass, UFID 13668.

REMARKS - This small crab is a symbiont of holothurians. It was collected by pressing black sea cucumbers (Holothuria atra Jaeger, 1833).

GEOGRAPHIC AND DEPTH RANGES - IWP, Red Sea, Mozambique to Hawaii, French Polynesia; subtidal to $60 \mathrm{~m}$.

Lupocyclus quinquedentatus Rathbun, 1906 (Figure 10I)

Material eXAMined - Mayotte KUW 2009, st. 23, Pass Choizil, 'Patate à Teddy', 15-30m, $1 \delta^{\lambda}$ $18.2 \times 23.5$ mm, MNHN B32502, MNHN-IU-2009-1264.

GEOGRAPHIC AND DEPTH RANGES - IWP, Seychelles, Mayotte (present study) to Hawaii, French Polynesia; subtidal, $15-151 \mathrm{~m}$.

Portunus convexus De Haan, 1835 (Figure 10J)

MATERIAL EXAMINED - Mayotte KUW 2009, no specimen collected, only color photograph (C. Hily, transmitted before fieldwork by P. Frouin, University Réunion), observation 18 April 2009, sandy bottom near seagrass beds of Thalassodendron northeastern large reef, $1 \mathrm{sp}$. about $30 \times 66 \mathrm{~mm}$ (with lateral spines).

REMARKS - Portunus convexus is recognized herein from a photograph only but with a few conspicuous characters: carapace pubescent; frontal teeth rounded; anterolateral margin of carapace with 9 spines, posterior-most the larger; two lateral pale patches outlined in brown on posterior carapace. The latter character (two patches on carapace) is useful to separate $P$. convexus from the affiliated $P$. pubescens (Dana, 1852) (see key in Stephenson, 1972: 15).

GEOGRAPHIC AND DEPTH RANGES - IWP, Eritrea, Somalia, Mayotte (present study) to Guam, French Polynesia; subtidal.

Portunus (Xiphonectes) cf. longispinosus (Dana, 1852) (Figure 10K)

MATERIAL EXAMINED - Mayotte KUW 2009, st. 12b-c, La Prévoyante Reef at night, 6-12m, 1 q CL 9.8 mm, MNHN B32493, MNHN-IU-2009-1255, 1 q juv. $8.5 \times 11.3 \mathrm{~mm}$ (20 mm with lateral spines), MNHN B32516, MNHN-IU-2009-1276 (this specimen similar to $P$. iranjae using key in Crosnier, 1962); st. 24, north Islet Handréma, 6-12m, $1 \delta^{\Uparrow} 15.1 \times 31.8 \mathrm{~mm}$ (with lateral spines), MNHN B32495, MNHN-IU-2009-1257, $1 ð 15.5 \times 36$ mm (with lateral spines), MHNH B32496, MNHN-IU-20091258.

REMARKS - Apel and Spiridonov (1998: 298) and Crosnier (2002: 407) have indicated that there is currently a confusion for species affiliated to Portunus (Xiphonectes) longispinosus s.l.: P. tenuicaudatus Stephenson, 1961, P. macrophthalmus Rathbun, 1906, P. iranjae Crosnier, 1962, and $P$. guinotae Stephenson and Rees, 1961. Portunus mariei Guinot, 1957 and Xiphonectes tuerkayi Spiridonov, 2017a, recently described from the Indian Ocean, can also be added to that 'longispinosus group'. A revision of these species is needed to confirm the identification of the Mayotte specimens.

GEOGRAPHIC AND DEPTH RANGES (P. (Xiphonectes) longispinosus) - IWP, ?Mayotte (present study), Madagascar, Réunion to Hawaii, French Polynesia; shallow subtidal to $305 \mathrm{~m}$. According to Spiridonov (2017a) Portunus (Xiphonectes) longispinosus s.s. is only in the intertidal and upper subtidal, other records of $P$. longispinosus being doubtful. 
Portunus mariei Guinot, 1957 (Figure 10L)

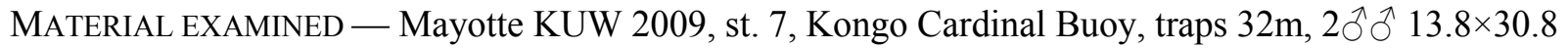
$\mathrm{mm}, 16.3 \times 36.3 \mathrm{~mm}$ (with lateral spines), MNHN B32492, MNHN-IU-2009-1254; st. 12b-c, La Prévoyante Reef at night, $6-12 \mathrm{~m}, 1 \widehat{\jmath} 16.4 \times 34 \mathrm{~mm}$ (to broken tip of lateral spines), MNHN B32491, MNHN-IU-2009-1253, 1 juv. 7.7×11.9 mm (20 mm with lateral spines), MNHN B32518, MNHN-IU$2009-1278,1 \lesssim 16.5 \times 23 \mathrm{~mm}$ (without lateral spines), 1 ㅇ $14.5 \times 21 \mathrm{~mm}$ (without lateral spines), MNHN B32494, MNHN-IU-2009-1256.

OTHER RECORDS - Portunus (Hellenus) mariei Guinot, 1957: 476, Mayotte, 1ठ 25×10 mm, branchial spine 5 mm, MNHN. - Crosnier, 1962: 61, Mayotte. - Guinot, 1967b: 258, list with Mayotte.

REMARKS - A species of the $P$. longispinosus group (see under $P$. cf. longispinosus) which is characterized by a 3-toothed front and extremely long lateral carapace spines.

GEOGRAPHIC AND DEPTH RANGES - IWP, Mayotte to New Caledonia ( $c f$. Ng and Richer de Forges, 2007; det. perhaps by K. Moosa, unpublished); subtidal to $60 \mathrm{~m}$.

Scylla serrata (Forskål, 1775) (Figure 10M)

MATERIAL EXAMINED - Mayotte KUW 2009, st. 13b, Malamani mangrove, coll. J. -M. Bouchard, 8 October 2008, 2 spp. including $1 \delta^{\Uparrow} 93.6 \times 140 \mathrm{~mm}$ (photo but specimen not retained in MNHN collection because of its large size), 19 juv. without chelae $9.2 \times 12.7 \mathrm{~mm}, \mathrm{MNHN}$ B32505, MNHN-

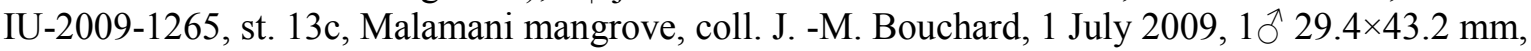
MNHN B32485, MNHN-IU-2009-1247.

OTHER RECORDS - Hoffmann, 1874: 9, Mayotte. - Guinot, 1967b: 258, list with Mayotte.

REMARKS - Scylla serrata has already been reported with mangrove species by Bouchard et al. (2013: 15). Male $29.4 \times 43.2 \mathrm{~mm}, \mathrm{MNHN}-\mathrm{IU}-2009-1247$ has a faint carinae on upper margin of palm instead of margin rounded in typical $S$. serrata, perhaps this is a juvenile character.

GEOGRAPHIC AND DEPTH RANGES - Red Sea, South Africa to Hawaii, French Polynesia; subtidal to $10 \mathrm{~m}$.

Thalamita admete (Herbst, 1803) (Figure 11A)

MATERIAL EXAMINED - Mayotte KUW 2009, st. 5, seagrass bed of great northeaster reef, $1 \mathrm{~m}, 1$ q $8.0 \times 13.1 \mathrm{~mm}, \mathrm{MNHN}$ B32519, MNHN-IU-2009-1279; st. 6, 'Déversoir Badamiers', intertidal, Petite Terre, 1 9 9.1×15 mm, MNHN B32520, MNHN-IU-2009-1280.

OTHER RECORDS - Crosnier, 1962: 96, Mayotte. - Guinot, 1967b: 255, list with Mayotte.

REMARKS - Specimens identified as Thalamita edwardsi Borradaile, 1900 by using key in Crosnier (1962) (but accepted as T. admete according to WoRMS, 2018). Carapace of largest specimens is glabrous while there is a faint pubescens in smallest specimens.

GEOGRAPHIC AND DEPTH RANGES - Tanzania, South Africa to Hawaii, French Polynesia, Pitcairn; subtidal to $120 \mathrm{~m}$.

Thalamita crenata Rüppell, 1830 (Figure 11B)

MATERIAL EXAMINED - Mayotte KUW 2009, st. 16, Longoni Bay, in front of mangrove, trap 2m, 1 + $42 \times 63.5 \mathrm{~mm}, 1$ q ov. $34.7 \times 52 \mathrm{~mm}, 3$ त̄ , MHNN B32477, MNHN-IU-2009-1239; st. 26, Mutsumbatsou reef flat, intertidal, $1 \delta^{\top} 21.3 \times 30.6$ mm, MNHN B32478, MNHN-IU-2009-1240.

REMARKS - Determination based the male G1, shape of $6^{\text {th }}$ segment of abdomen and live coloration, with blue shades on chelae and orange tints on the articulations of legs (color illustration in Vannini and Innocenti, 2000: 289, fig. 87). Now in genus Thranita (see Evans, 2018).

GEOGRAPHIC AND DEPTH RANGES - Red Sea, Mayotte (present study), South Africa to Hawaii, French Polynesia; intertidal, subtidal to $10 \mathrm{~m}$. 
Thalamita gatavakensis Nobili, 1906 (Figure 11D)

MATERIAL EXAMINED - Mayotte KUW 2009, st. 14, Bank Prudente, $15-17 \mathrm{~m}, 3 \widehat{\jmath} \widehat{\jmath} 4.1 \times 6.4$ to $6.5 \times 10.3$

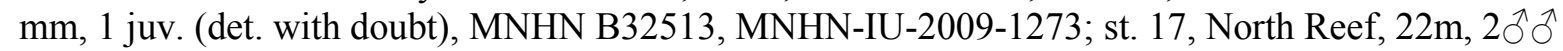
$4.6 \times 7.2 \mathrm{~mm}, 5.3 \times 8.2 \mathrm{~mm}, 2$ 우 ov. $4.85 \times 7.9 \mathrm{~mm}, 5.4 \times 8.4 \mathrm{~mm}, 1$ ㅇ $5.2 \times 8.4 \mathrm{~mm}, 2$ juv., MNHN B32512, MNHN-IU-2009-1272.

REMARKS - The outer face of palm of chela has three granulated costae. The male G1 is illustrated in Crosnier (1962: 107, fig. 177). Specimens registered in MNHN as 'Thalamita pilumnoides var. gatavakensis Nobili, 1906'.

GEOGRAPHIC AND DEPTH RANGES - Kenya, Mayotte (present study), Madagascar to French Polynesia; intertidal to $22 \mathrm{~m}$.

Thalamita helleri Hoffmann, 1874 (Figure 11C)

MATERIAL EXAMINED - Mayotte KUW 2009, st. 2, intertidal between Trévani beach to Kangani

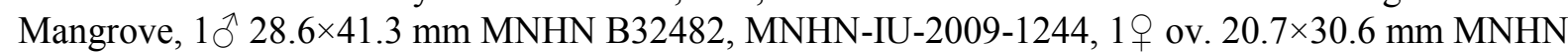
B32498, MNHN-IU-2009-1260, $1 \overbrace{}^{\lambda} 21.3 \times 31.3 \mathrm{~mm}$, MNHN B32500, MNHN-IU-2009-1262, $1 \hat{\jmath}$ juv. $9.4 \times 13.1 \mathrm{~mm}$, MNHN B32525, MNHN-IU-2009-1285 (with hesitation, dactyl of P5 blue but male G1 not strongly curved; ?juvenile aspect); st. 6, 'Déversoir Badamiers', Petite Terre, $1 \sigma^{\Uparrow} 27.7 \times 41.3 \mathrm{~mm}$, 1 juv., 2 juv., MNHN B32481, MNHN-IU-2009-1243, 1 + 31.7×47.4 mm, MNHN 32483, MNHN-

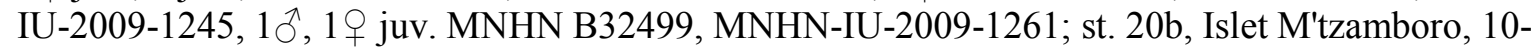
$15 \mathrm{~m}, 1$ ㅇ (soft carapace), MNHN B32484, MNHN-IU-2009-1246; st. 26, intertidal, western reef flat,

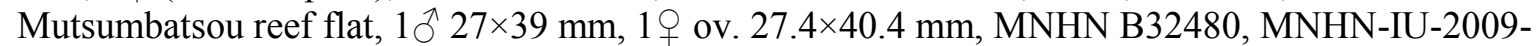
1242; st. 29, littoral, beach, Mboianatsa, Ngouja Hotel, 1 ㅇ $17.3 \times 26.6$ mm, MNHN B32497, MNHNIU-2009-1259; st. 38, southwest bay Chiconi/Sada, coll. J. -M. Bouchard/V. Dinhut, 24/07/2008, 1 ㅇ juv. 10.4×15.4 mm, MNHN B32514, MNHN-IU-2009-1274; st. 39, Sohoa Beach, coll. J. -M. Bouchard, V. Dinhut, 01/07/09, 1 ð 27.4×39.6 mm, MHNN B32479, MNHN-IU-2009-1241.

OTHER RECORDS - Thalamita foresti - Poupin et al., 2013c: 11, Glorieuses, 1 sp. MNHN-IU-2013-7312.

REMARKS - All specimens from Mayotte registered in MNHN collection as 'Thalamita foresti Crosnier, 1962' are currently accepted as Thalamita helleri in WoRMS (2018; see also remarks in Apel and Spiridonov, 1998: 241). A few specimens were confused on the field with $T$. crenata that has superficial resemblances. Thalamita helleri has a pilose carapace, 5 sub-equal spines on anterolateral margin of carapace, and tip of male G1 bent at about $180^{\circ}$ (vs. of almost straight in T. crenata, see Crosnier, 1962, figs 230-233). On live specimens of T. helleri the dactyl of swimming P5 is colored in blue, a useful character for first sorting of the specimens in the field. Another species that can be confused with T. helleri is Thalamita danae Stimpson, 1858 (see Crosnier, 1962; Apel and Spiridonov, 1988). Now in genus Thranita (see Evans, 2018).

GEOGRAPHIC AND DEPTH RANGES - IWP, Gulf of Aden, Mayotte (present study), Mozambique, Madagascar to Philippines, New Caledonia (from Spiridonov, 2017b, as T. foresti); intertidal, subtidal.

Thalamita integra Dana, 1852 (Figure 11E)

MATERIAL EXAMINED - Mayotte KUW 2009, st. 1, intertidal, beach, Trévani, $1{ }^{\Uparrow} 9.2 \times 14.8 \mathrm{~mm}$, MNHN B32489, MNHN-IU-2009-1251.

REMARKS - This species is affiliated to Thalamita admete (Herbst, 1803), also collected during KUW fieldwork. The determination is based on aspect of male G1, illustrated by Vannini and Innocenti (2000: 278, fig. 54), and the outer face of palm smooth with a single costa along ventral margin, extended to fixed finger.

GEOGRAPHIC AND DEPTH RANGES - IWP, Red Sea, Mayotte (present study), South Africa to Hawaii, French Polynesia; intertidal to $11 \mathrm{~m}$. 


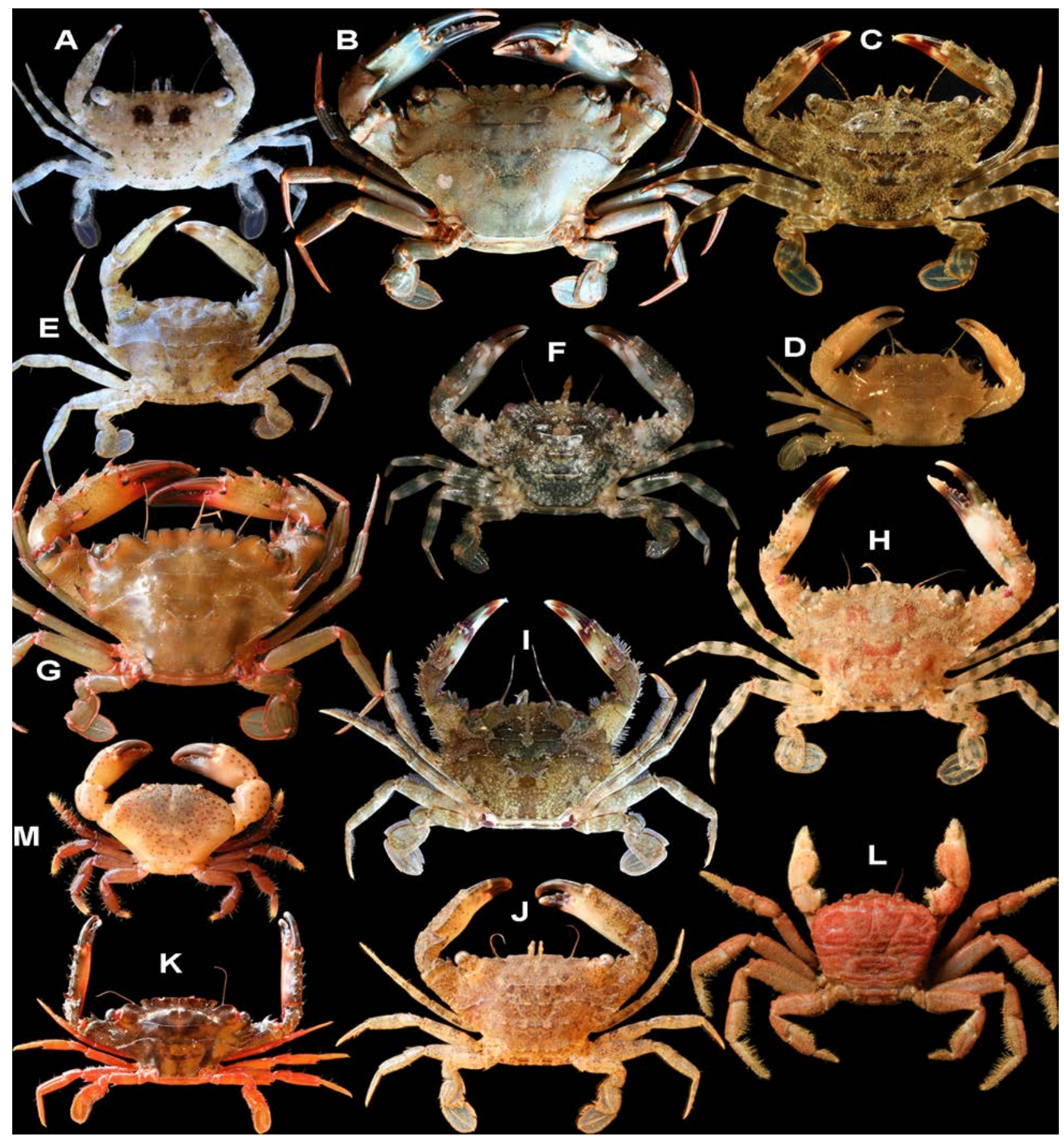

Figure 11. Crabs from Mayotte KUW 2009. Portunidae - A) Thalamita admete, 1 q $8.0 \times 13.1 \mathrm{~mm}$, MNHN-IU-2009-1279; B) T. crenata, $1942 \times 63.5 \mathrm{~mm}$, MNHN-IU-2009-1239; C) T. helleri, 1 운 $17.3 \times 26.6 \mathrm{~mm}$, MNHN-IU-2009-1259; D) T. gatavakensis, $1 \bigcirc^{\top} 6.5 \times 10.3 \mathrm{~mm}$ (preserved), MNHN-IU-

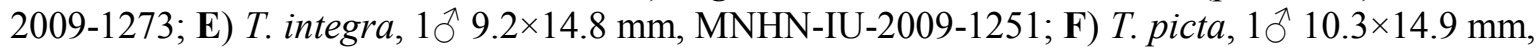
MNHN-IU-2012-618 (specimen from Europa, Mozambique Channel); G) T. prymna, 1 $37.2 \times 52.8 \mathrm{~mm}$, MNHN-IU-2009-1236; H) T. quadrilobata, $1{ }^{\lambda} 20.5 \times 34.6$ mm, MNHN-IU-2009-1252; I) T. spinifera,

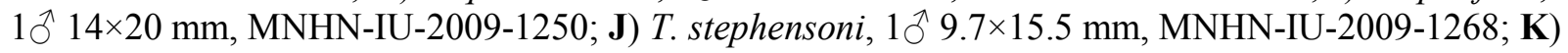
Thalamitoides quadridens, $1 \mathrm{sp} .18 .7 \times 33 \mathrm{~mm}$, st. $21 \mathrm{~b}$, not collected. Pseudozioidea - L) Planopilumnus spongiosus, 1 \% $11.4 \times 14.8$ mm, MNHN-IU-2009-1155; M) Pseudozius caystrus, $1 \lesssim 10.8 \times 17.8 \mathrm{~mm}$, MNHN-IU-2009-2597. 


\section{Thalamita ?mitsiensis Crosnier, 1962}

MATERIAL EXAMINED - Mayotte KUW 2009, st. 33, Pass Longoni-M'tzamboro, 25m, 19 ov. damaged about $6.7 \times 8.9 \mathrm{~mm}$, MNHN B32526, MNHN-IU-2009-1286.

OTHER RECORDS - Thalamita mitsiensis - Crosnier and Thomassin, 1975: 1114, Comoros, Mohéli, foraminiferous sand, dredge 24m, 26 January 1970, R. Plante coll. 1 ㅇ $8.6 \times 12.0 \mathrm{~mm}$, MNHN.

REMARKS - Determination of this female is uncertain because it is in poor condition and the male G1 is not available. The anterolateral margin of carapace has 4 teeth and the shape of the front is similar to T. mitsiensis, as illustrated in Crosnier (1962, fig. 212)

GEOGRAPHIC AND DEPTH RANGES - IWP, Comoros, ?Mayotte (present study), Madagascar to Japan, French Polynesia; 24-85m.

Thalamita picta Stimpson, 1858 (Figure 11F)

MATERIAL EXAMINED - Mayotte KUW 2009, st. 26, intertidal, Mutsumbatsou reef flat, coll. J. -M. Bouchard 2008, st. Mliha, $1 \sigma^{\uparrow} 6.9 \times 10 \mathrm{~mm}, 1$ ov. $10.3 \times 15.8 \mathrm{~mm}, 1$ q juv. $7.6 \times 11.3 \mathrm{~mm}, \mathrm{MNHN}$ B32506, MNHN-IU-2009-1266.

OTHER RECORDS - Thalamita picta - Crosnier, 1962: 138, Comoros, Anjouan, Mayotte, Glorieuses. Guinot, 1967b: 256, list with Mayotte. - Poupin et al., 2013c: 11, Glorieuses, 1 i juv $6.8 \times 9.5 \mathrm{~mm}$ MNHN-IU-2013-7311.

REMARKS - The specimens have been determined by using characters and illustrations in Crosnier (1962). The tip of the male G1 is broadened, flared and truncated (illustrated in Vannini and Innocenti, 2000: 282, fig. 66). The specimen photographed from Mayotte was already preserved, consequently another fresh crab collected in 2011 from Europa Island, Mozambique Channel (Poupin et al., 2013b) is presented. Spiridonov (2017b) has recently described a new species from Japan, Thalamita matzuzawai, related to T. picta. He has provided a comparative table of diagnostic characters for these two species and 4 others related Thalamita.

GEOGRAPHIC AND DEPTH RANGES - IWP, Red Sea, South Africa to Hawaii, French Polynesia and Clipperton; intertidal, subtidal to $159 \mathrm{~m}$.

Thalamita prymna (Herbst, 1803) (Figure 11G)

MATERIAL EXAMINED - Mayotte KUW 2009, st. 7, trap, Kongo Cardinal Buoy, 32m, 1 q 37.2×52.8 mm, MNHN B32474, MNHN-IU-2009-1236; st. 38, southwest, Bay Chiconi/Sada, coll. J. -M. Bouchard, V. Dinhut, 24/07/08, 1 § 37×62 mm, MNHN B32475, MNHN-IU-2009-1237.

OTHER RECORDS - Thalamita prymnoa (sic) Herbst - Hoffmann, 1874: 39, Mayotte (indicated in list but not p. 9 where this species is presented). - Thalamita prymna - Milne-Edwards, 1873: 164 'Le Muséum d'histoire naturelle en possède de nombreux représentants provenant de Mayotte'. - Crosnier, 1962: 136, synonymy, including Hoffman (1874).

REMARKS - Specimens were identified by using keys in Crosnier (1962), Stephenson (1972) and Apel and Spiridonov (1988). Some variations are attributed to their large size: a) almost no pubescens on carapace; b) ridge of carapace, between $2^{\text {nd }}$ anterolateral teeth, reduced, present only on mesogastric region; c) on the outer face of palm T. prymna has three costae but on specimens examined only inferior costa is obvious, upper and median costae being reduced to granules. Now in genus Thranita (see Evans, 2018).

GeOGRAPHIC AND DEPTH RANGES - IWP, Red Sea, South Africa to Japan, French Polynesia; intertidal to $32 \mathrm{~m}$ (present study).

Thalamita quadrilobata Miers, 1884 (Figure 11H)

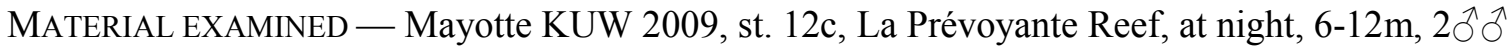
$9.5 \times 14.1 \mathrm{~mm}, 10.3 \times 14.9 \mathrm{~mm}, \mathrm{MNHN}$ B32515, MNHN-IU-2009-1275; st. 35, Surprise Reef, Pass 
Longoni-M'tzamboro, 4-25m, 1 đ 20.5×34.6 mm, 1 quv. with Sacculina, MNHN B32490, MNHNIU-2009-1252.

OTHER RECORDS - Crosnier and Thomassin, 1976: 1114, Mayotte, sand around reef, coll. R. Plante, 21 January 1970,1 , $7.7 \times 12.5 \mathrm{~mm}, \mathrm{MNHN}$.

REMARKS - Specimens examined agree well with diagnosis and illustrations of Apel and Spiridonov (1988: 260), including shape of male G1 with rows of strong subterminal spines on mesial and lateral faces.

GEOGRAPHIC AND DEPTH RANGES - IWP, Red Sea, Mozambique Channel (Mayotte, Europa) to Marshall Islands, Kiribati, French Polynesia; subtidal to $25 \mathrm{~m}$.

Thalamita spinifera Borradaile, 1902 (Figure 11I)

MATERIAL EXAMINED - Mayotte KUW 2009, st. 1, intertidal, beach, Trévani, $1{ }^{\Uparrow} 14 \times 20 \mathrm{~mm}$, MNHN B32488, MNHN-IU-2009-1250.

OTHER RECORDS - Crosnier, 1975: 724, Mayotte.

GEOGRAPHIC AND DEPTH RANGES - Mayotte, Madagascar to Hawaii, French Polynesia; intertidal (present study) and 20-433m.

Thalamita stephensoni Crosnier, 1962 (Figure 11J)

MATERIAL EXAMINED - Mayotte KUW 2009, st. 2, littoral, Trévani beach to Kangani Mangrove, intertidal, 1 q ov. $7.9 \times 12.5$ mm, MNHN B32509, MNHN-IU-2009-1269; st. 29, intertidal, beach, Mboianatsa Ngouja Hotel, $2 \widehat{\jmath}$ 8.0×12.4 mm, 9.8×15.8 mm, MNHN B32507, MNHN-IU-2009-1267;

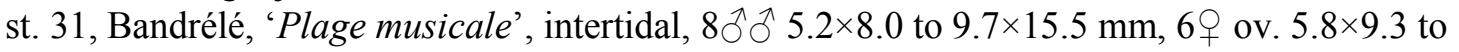
7.6×12.0 mm, 2 juv., MNHN B32508, MNHN-IU-2009-1268.

REMARKS - A species of small size characterized by spoon shaped fingers of chelae; a unique feature for Thalamita species. The anterolateral margin of carapace has five teeth, the $4^{\text {th }}$ being much reduced, sometimes hardly visible. Male G1 is cross shaped at tip.

GEOGRAPHIC AND DEPTH RANGES — Somalia, Kenya, Mayotte (present study), Madagascar to Hawaii, Samoa; intertidal.

Thalamitoides quadridens A. Milne-Edwards, 1869 (Figure 11K)

MATERIAL EXAMINED - Mayotte KUW 2009, st. 4, La Prévoyante Reef, 6-10m, 1ठ 4.9×8.2 mm, 3 spp. in poor condition (from brushing of substrate), MNHN B32511, MNHN-IU-2009-1271; st. 12, La Prévoyante Reef, 6-12m, 3 juv. in poor condition, det. with hesitation, 1 carapace $18.5 \times 30.5 \mathrm{~mm}$; st. 14, Bank Prudente, 15-17m, 1ठ 4.6×8.4 mm, MNHN B32510, MNHN-IU-2009-1270; st. 19, north Islet Handréma, 6-10m, 1へ 16.2×30 mm, 1 juv. 5.8×10.6 mm MNHN B32486, MNHN-IU-20091248; st. 21b, Islet Choizil, east Malandzamiayatsini, $15-20 \mathrm{~m}, 1 \mathrm{sp} .18 .7 \times 33 \mathrm{~mm}$, field notes and photo only not collected; st. 22, Islet Choizil, west Malandzamiayajou, $30-35 \mathrm{~m}$, field notes only several specimens, not collected; st. 27, Islet Mbouzi, 'Patate sud-est', 4-20m, 2 spp., field notes only, not collected; st. 35, Surprise Reef, Pass Longoni-M'tzamboro, 4-25m, field notes only, not collected.

OTHER RECORDS - Poupin et al., 2013: 11, Glorieuses.

REMARKS - This is a first record for Mayotte although the species was observed at many stations, usually in corals, during the KUW 2009 expedition.

GEOGRAPHIC AND DEPTH RANGES — Red Sea, Mayotte (present study), Mozambique Channel (Europa) to Hawaii, French Polynesia; subtidal to $65 \mathrm{~m}$.

Superfamily Pseudozioidea Alcock, 1898

Family Planopilumnidae Serène, 1984 
Planopilumnus spongiosus (Nobili, 1906) (Figure 11L)

MATERIAL EXAMINED - Mayotte KUW 2009, st. 29, intertidal, beach, Mboianatsa, Ngouja Hotel, $1 \delta^{\lambda}$ juv. 5.2×6.4 mm, 1 ㅇ $11.4 \times 14.8 \mathrm{~mm}$, det. P. K. L. Ng, MNHN B32382, MNHN-IU-2009-1155.

REMARKS - This species was recognized from our photographs by P. K. L. Ng. After the revision of genus Planopilumnus by $\mathrm{Ng}(2010)$ and a description of a new species from Pakistan (P. holthuisi) by $\mathrm{Ng}$ and Kazmi (2011), only two species are currently assigned to this genus, namely P. spongiosus, and $P$. holthuisi.

GEOGRAPHIC AND DEPTH RANGES - WIO, Red Sea to Mayotte (present study), Madagascar; intertidal.

\section{Family Pseudoziidae Alcock, 1898}

Pseudozius caystrus (Adams and White, 1849) (Figure 11M)

MATERIAL EXAMINED - Mayotte KUW 2009, st. 4, 15, 20, 29, field notes no specimens collected; st. 6, 'Déversoir Badamiers', Petite Terre, intertidal, 1 ㅇ 10.2×16.9 mm, MNHN-IU-2009-2596; st. 10, $1{ }^{\wedge}$

$7.2 \times 11.4$ mm, MNHN-IU-2009-2595; st. 26, $1{ }^{\Uparrow} 10.8 \times 17.8$ mm, MNHN-IU-2009-2597.

OTHER RECORDS - Pseudozius caystrus - Guinot, 1958c: 276, Mayotte, $1913.5 \times 8 \mathrm{~mm}$ MNHN. -

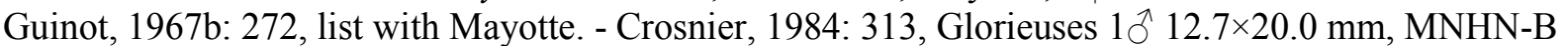
8760. - Poupin et al., 2013c: 11, Glorieuses.

REMARKS - This species is common in the intertidal. It has superficial resemblances with Epixanthus frontalis and was confused with this species at several stations in field notes. The shape of the male G1 is a good character to separate the two species, short without distal flagellum in Pseudozius caystrus (see Crosnier, 1984: 313, figs 242-243) versus long with a coiled distal flagellum in Epixanthus frontalis (see Serène, 1984: 306, figs 222-223).

GEOGRAPHIC AND DEPTH RANGES — Red Sea, South Africa to Hawaii, French Polynesia; intertidal.

\section{Superfamily Trapezioidea Miers, 1886}

\section{Family Domeciidae Ortmann, 1893}

Domecia glabra Alcock, 1899 (Figure 12A)

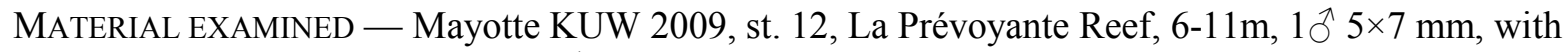

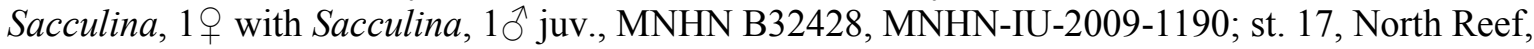
22m, $1 \overbrace{}^{\Uparrow} 4 \times 5 \mathrm{~mm}$, MNHN-IU-2009-2643.

REMARKS - Some specimens confused with Domecia hispida in field notes. In Guinot (1964a, key) Domecia glabra has the following characters: a) distal part of thoracic sternum short, not elongated; b) dorsal margin of P5 merus with spines on distal part only. Live coloration is useful to separate $D$. glabra and D. hispida, being much paler in D. glabra (see Figure 12A-B).

GEOGRAPHIC AND DEPTH RANGES - IWP, Tanzania, Mayotte (present study), Madagascar to Hawaii, French Polynesia; shallow subtidal to $75 \mathrm{~m}$.

Domecia hispida Eydoux and Souleyet, 1842 (Figure 12B)

MATERIAL EXAMINED - Mayotte KUW 2009, st. 14, Bank Prudente, 15-17m, 1 đ 4.2×5.2 mm, MNHNIU-2009-2644; st. 32, northeast Islet M'tzamboro, 6-21m, 2 §ิ $4.2 \times 5.4 \mathrm{~mm}, 5.0 \times 6.6 \mathrm{~mm}$ (with Sacculina), MNHN B32291, MNHN-IU-2009-1109.

REMARKS - Diagnostic characters for D. hispida are: a) distal part of thoracic sternum narrow and elongated; b) dorsal margin of P5 merus with spines along entire margin; c) live color (see Figure 12A-B). 
GEOGRAPHIC AND DEPTH RANGES - IP, Red Sea, Kenya, Mayotte (present study), Europa (southernmost record in Mozambique Channel, $c f$. Poupin et al., 2013b) to Hawaii, French Polynesia, Easter Island, Clipperton, Gulf of California, Equator; subtidal to 50-90m.

\section{Family Tetraliidae Castro, Ng and Ahyong, 2004}

Tetralia cinctipes Paul'son, 1875 (Figure 12C)

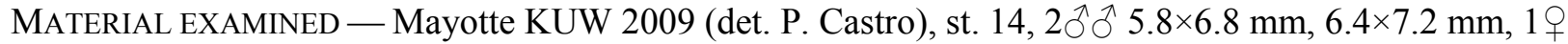
ov. $6.2 \times 7.5 \mathrm{~mm}, \mathrm{MNHN}$ B32242, MNHN-IU-2009-1060; st. $21 \mathrm{~b}, 1$ ov. $5.5 \times 6.5 \mathrm{~mm}, \mathrm{MNHN}$ B32243, MNHN-IU-2009-1061; st. 25, 1 q ov. 5.5×6.6 mm, MNHN B32244, MNHN-IU-2009-1062.

OTHER RECORDS - Tetralia glaberrima f. pullidactyla - Serène, 1984: 282, Zélée Bank, coll. A.J. Bruce $1{ }^{\Uparrow} 5.8 \times 6.7 \mathrm{~mm}, 1$ q $6.9 \times 8.4 \mathrm{~mm}$, MNHN B8169 / T. glaberrima f. pullidactyla Patton, 1966 accepted as T. cinctipes in WoRMS (2018). - Tetralia cinctipes - Castro, 1997: 65, Zélée Bank, MNHN B8169. - Castro, 1999a: 101, Mayotte, coll. Humboldt 1901, 2ð̄ô MNHN B13907; Zélée Bank, 10̂, 1 ㅇ MNHN B8169 and Geyser Bank, 1ð, 1 q MNHN B25276, coll. A.J. Bruce March 1972.

GEOGRAPHIC AND DEPTH RANGES - IWP, Red Sea, Europa (southernmost record in Mozambique Channel, $c f$. Poupin et al., 2013b), Madagascar to Japan, French Polynesia; subtidal to $30 \mathrm{~m}$.

Tetralia glaberrima (Herbst, 1790) s.l. (Figure 12D)

MAterial EXAMINED - Mayotte KUW 2009 (det. P. Castro, J. Poupin), st. 3a, $2 \hat{\jmath} \widehat{o} 9.0 \times 9.5 \mathrm{~mm}$, $9.3 \times 10.3 \mathrm{~mm}, 1$ q ov. $10.8 \times 12.5 \mathrm{~mm}, \mathrm{MNHN}$ B32128, MNHN-IU-2009-1047; st. 4, 1 § $6.4 \times 7.2 \mathrm{~mm}$, MNHN B32129, MNHN-IU-2009-1048; st. 8, $1 \overbrace{}^{\Uparrow} 10.8 \times 11.9$ mm, MNHN B32130, MNHN-IU-2009-

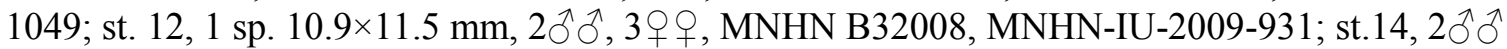
$6.8 \times 7.4 \mathrm{~mm}, 6.9 \times 7.8 \mathrm{~mm}, 3$ 우 ov. $4.4 \times 5.2 \mathrm{~mm}, 4.6 \times 5.3 \mathrm{~mm}$, and $6.8 \times 7.8 \mathrm{~mm}, \mathrm{MNHN}$ B32232, MNHN-IU-2009-1050; st. 14,2 우 ov. $5.4 \times 6.2 \mathrm{~mm}, 8.7 \times 10.2 \mathrm{~mm}$, MNHN B32233, MNHN-IU2009-1051; st. 17, 1 q ov. $4.5 \times 5.5$ mm, MNHN B32234, MNHN-IU-2009-1052; st. 19, $2 \widehat{\jmath}$, MNHN

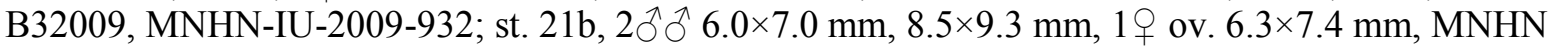
B32235, MNHN-IU-2009-1053; st. 22,3 $\widehat{\partial} 4.0 \times 4.8$ to $6.2 \times 6.6 \mathrm{~mm}, 1 \mathrm{sp}$ with bopyrid, MNHN B32236, MNHN-IU-2009-1054; st. 23, 3 ते $4.0 \times 4.8$ to $6.2 \times 6.6 \mathrm{~mm}, 1 \mathrm{sp}$ with bopyrid, MNHN B32237, MNHN-IU-2009-1055; st. 25, 1 त 4.6×5.5 mm, 1 ㅇ ov. $6.3 \times 7.3 \mathrm{~mm}$, MNHN B32238, MNHN-IU-2009-1056; st. $30,1 \delta^{\Uparrow} 6.5 \times 7.5 \mathrm{~mm}, 1$ ov. $7.4 \times 8.5 \mathrm{~mm}, \mathrm{MNHN}$ B32239, MNHN-IU2009-1057.

OTHER RECORDS - Tetralia glaberrima - Guinot, 1958c: 279, Mayotte, $1 \overbrace{}^{\lambda} 8 \times 8 \mathrm{~mm}$ MNHN. - Tetralia fulva - Castro, 1999a: 102, Mayotte, coll. M. Marie, 19, MNHN B25687 / T. fulva Serène, 1984 accepted as $T$. glaberrima in WoRMS (2018).

REMARKS - Specimens from Mayotte KUW 2009 are attributed to T. glaberrima s.l. because potentially belonging to a new species affiliated to T. glaberrima s.s (pers. comm. S. Trautwein, S. McKeon, and P. Castro). Samples MNHN-IU-2009-931/932, sent to S. Trautwein (in 2009) for more examination and sequencing.

GEOGRAPHIC AND DEPTH RANGES — IWP, Red Sea, Mozambique to Japan, French Polynesia; subtidal to 40-50m.

Tetralia ?nigrolineata Serène and Pham, 1957 (Figure 12E)

MATERIAL EXAMINED - Mayotte KUW 2009 (det. P. Castro, with hesitation), st. 12a, $194.9 \times 5.8 \mathrm{~mm}$, MNHN B32240, MNHN-IU-2009-1058; st. 14, 1 ^ 3.5×4.3 mm, MNHN B32241, MNHN-IU-20091059 . 


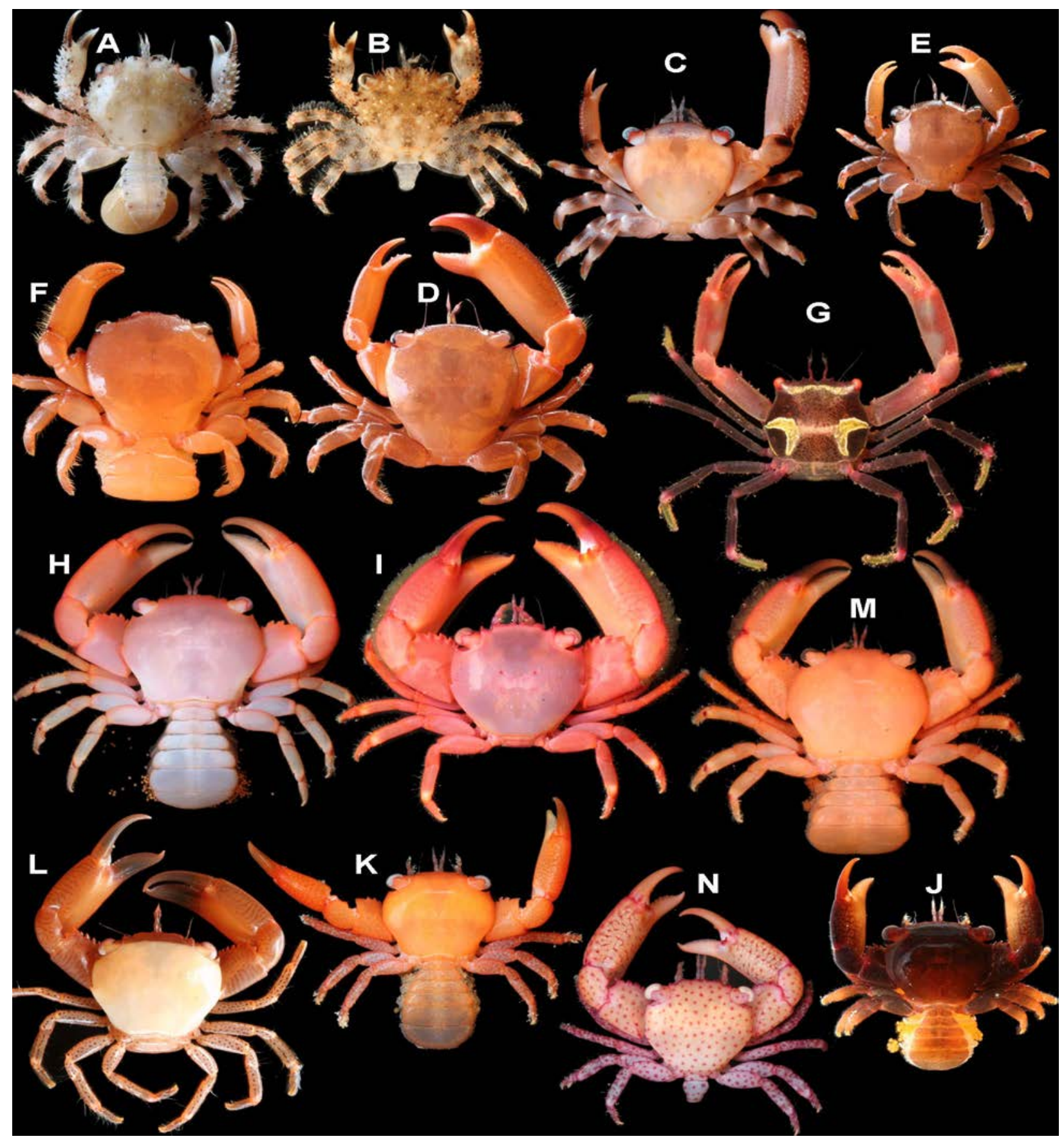

Figure 12. Crabs from Mayotte KUW 2009. Trapezioidea - A) Domecia glabra, 1 त $5 \times 7 \mathrm{~mm}$, with Sacculina, MNHN-IU-2009-1190; B) D. hispida, 1ठ 4.2×5.4, MNHN-IU-2009-1109; C) Tetralia cinctipes, $1{ }^{\lambda} 6.4 \times 7.2 \mathrm{~mm}$, MNHN-IU-2009-1060; D) T. glaberrima s.1., $1 \mathrm{sp} .10 .9 \times 11.5 \mathrm{~mm}$, MNHNIU-2009-931; E) T. ?nigrolineata, $194.9 \times 5.8 \mathrm{~mm}$, MNHN-IU-2009-1058; F) T. rubridactyla s.l., $1 q$ ov. $11 \times 12$ mm, MNHN-IU-2009-933; G) Quadrella maculosa, $196.8 \times 8.7$ mm, MNHN-IU-2009-1083; H) Trapezia bidentata, 1 우 $11.5 \times 14.5 \mathrm{~mm}$, MNHN-IU-2009-939; I) T. cymodoce, 1 तึ $11.5 \times 13.7 \mathrm{~mm}$, MNHN-IU-2009-944; J) T. digitalis, 1 ㅇ ov. $6.3 \times 8.0 \mathrm{~mm}$, MNHN-IU-2009-1085; K) T. formosa, 1 ㅇ ov. 5.5×7.2 mm, MNHN-IU-2009-1084; L) T. guttata, 1 ㅇ 8.5×11.3 mm, MNHN-IU-2009-1086; M) T. lutea, 1 ov. $10.8 \times 12.8 \mathrm{~mm}, \mathrm{MNHN}-\mathrm{IU}-2009-935$; N) T. richtersi, 1 §̊ $7.3 \times 8.5 \mathrm{~mm}, \mathrm{MNHN}-\mathrm{IU}-2009-1098$. 
REMARKS - The color pattern of typical T. nigrolineata is illustrated, for a male and female, in Castro (1997: 101, pl. 1D) showing black lines on frontal and lateral margin of carapace. These lines are unclear in the female $4.9 \times 5.8 \mathrm{~mm}$ of Figure $12 \mathrm{E}$, perhaps because of its juvenile condition?

GEOGRAPHIC AND DEPTH RANGES - Mozambique, ?Mayotte (present study) to Japan, New Caledonia; subtidal to $66 \mathrm{~m}$.

Tetralia rubridactyla Garth, 1971 s.l. (Figure 12F)

MATERIAL EXAMINED - Mayotte KUW 2009 (det. P. Castro, with hesitation), st. 14, 1q 10.6×12.3 mm, 1 o ov. $11 \times 12 \mathrm{~mm}, 1$,, MHNH B32010, MNHN-IU-2009-933; st. 23, 1 సै damaged CW $6.8 \mathrm{~mm}$, MNHN B32245, MNHN-IU-2009-1063.

OTHER RECORDS - Tetralia rubridactyla - Castro, 1999a: 103, Mayotte, coll. M. Marie, 1ð̂, 19, MNHN B13913, Leven Bank, coll. A.J. Bruce, 1971, 1 9 MNHN B13342, Geyser Bank, coll. A.J. Bruce,

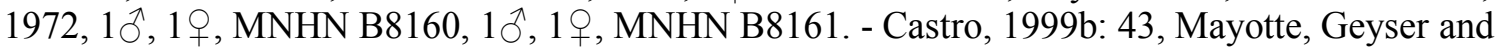
Leven banks, same MNHN lots.

REMARKS - The specimens from Mayotte are determined with hesitation by P. Castro and have been sent for sequencing to S. Trautwein (2009). The western Indian population of T. rubridactyla is perhaps distinct from Coral Sea and western Pacific populations. Color variation of live specimens from these areas is discussed in Castro (1999b: 44).

GEOGRAPHIC AND DEPTH RANGES — IWP, Somalia, Mozambique to Japan, French Polynesia; subtidal to 20-30m.

\section{Family Trapeziidae Miers, 1886}

Quadrella maculosa Alcock, 1898 (Figure 12G)

MATERIAL EXAMINED - Mayotte KUW 2009, st. 18, S-shaped Pass, terrace at 50-60m, in antipatharian, $196.8 \times 8.7$ mm, MNHN B32265, MNHN-IU-2009-1083.

GEOGRAPHIC AND DEPTH RANGES - Red Sea, Mayotte (present study), Mozambique to Japan, French Polynesia; $27-37 \mathrm{~m}$ to $372-466 \mathrm{~m}$.

Trapezia bidentata (Forskål, 1775) (Figure 12H)

MATERial eXAmined - Mayotte KUW 2009 (det. P. Castro, J. Poupin), st. 11, $1 q$ ov. 11×14 mm, MNHN-B32020, MNHN-IU-2009-942, 1 त 10×12 mm, MNHN B32246, MNHN-IU-2009-1064; st.

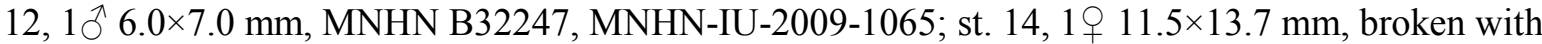
Sacculina, MNHN B32019, MNHN-IU-2009-941, 4우 4.5×5.7 to 7.0×8.6 mm, MNHN B32248, MNHN-IU-2009-1066; st. 23, 1 1 11.5×14.5 mm, MNHN-B32017, MNHN-IU-2009-939, $197.8 \times 9.8$ mm, MNHN-B32021, MNHN-IU-2009-943, 1ठ 13.3×16.3 mm (carapace broken), MNHN B32018,

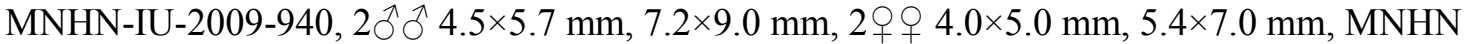

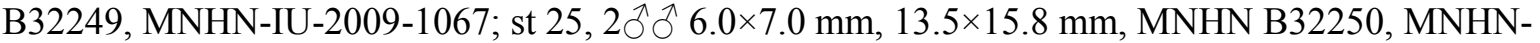
IU-2009-1068.

OTHER RECORDS - Trapezia ferruginea - Serène, 1984: 273, Glorieuses, intertidal, coll. A. Crosnier, 16 September 1958, $2 \widehat{\jmath}$ largest $10.8 \times 12.5 \mathrm{~mm}, 2$ 우 largest $11.1 \times 13.5 \mathrm{~mm}$, MNHN-B 8233; Mayotte, 10m, coral, coll. A. Crosnier, September 1959, 1 + 10.4×12.3 mm, MNHN-B 8234. - Castro, 1999a: 108, Mayotte, Glorieuses / T. ferruginea Latreille, 1825 accepted as T. bidentata in WoRMS (2018) Trapezia bidentata - Poupin et al., 2013c: 11, Glorieuses.

REMARKS - Alive, the largest specimens have a bluish carapace and smaller specimens are orange; in all specimens the distal part of P2-P5 propodi is red. One specimen from st 11 ( $q$ ov. $12.3 \times 15.3 \mathrm{~mm}$, MNHN-IU-2009-1091) with tomentum on chelipeds attributed in error by J. Poupin to ' $T$. bidentata pilose' corrected by P. Castro into T. lutea (see remarks under T. lutea).

GEOGRAPHIC AND DEPTH RANGES - IP, Red Sea, South Africa to Hawaii, French Polynesia, Clipperton, Gulf of California, Colombia; shallow subtidal to $55 \mathrm{~m}$. 
Trapezia cymodoce (Herbst, 1801) (Figure 12I)

MATERIAL EXAMINED - Mayotte KUW 2009, st. 20b, $1 \overbrace{}^{\Uparrow} 5.3 \times 6.4$ mm, MNHN B32251, MNHN-IU2009-1069; st. 23, 1 đ $11.5 \times 13.7$ mm, MNHN-B32022, MNHN-IU-2009-944, 1 ๙ $6.3 \times 7.7 \mathrm{~mm}$, MNHN B32252, MNHN-IU-2009-1070; st. 30, 10 9.0 10.8 mm, MNHN-B32023, MNHN-IU-2009945, 1 ㅇ with Sacculina $10.0 \times 12.0$ mm, MNHN-B32024, MNHN-IU-2009-946; st. 32, 10 8.0 $\times 9.5$ mm, MNHN B32253, MNHN-IU-2009-1071; st. 35, 1 ㅇ ov. $11.0 \times 14.0$ mm, MNHN B32025, MNHNIU-2009-947, 1 ð 12.2×14.5 mm, MNHN B32026, MNHN-IU-2009-948.

OTHER RECORDS - Trapezia cymodoce - Miers, 1884: 535, Glorieuses, coll. Coppinger, HMS Alert, in NHM. - Castro, 1999a: 106, Mayotte, Glorieuses. - Coll. Anker and Michonneau, 2008, Mayotte, st. MAY08-St6, S-shaped Pass, UF13676, 13684.

GEOGRAPHIC AND DEPTH RANGES - IWP, Red Sea, South Africa to Japan, French Polynesia; subtidal to $59 \mathrm{~m}$. Several IWP records probably confused with T. lutea, with similar tomentum along outer edge of palm.

Trapezia digitalis Latreille, 1828 (Figure 12J)

MATERIAL EXAMINED - Mayotte KUW 2009, st. 14, Bank Prudente, $1 \overbrace{}^{\Uparrow} 5.8 \times 7.2$ mm, 1 q ov. $6.3 \times 8.0$ mm, MNHN B32267, MNHN-IU-2009-1085.

OTHER RECORDS - Trapezia digitalis - Serène, 1984: 277, Glorieuses, intertidal, coral, coll. A. Crosnier 16 September 1958, $1 \bigcirc^{\Uparrow} 6.2 \times 7.6$ mm, MNHN-B 8264. - Castro, 1999a: 107, Glorieuses, MNHN B8264.

GEOGRAPHIC AND DEPTH RANGES - IP, Red Sea, South Africa to Hawaii, French Polynesia, Clipperton, Mexico, Equator, Colombia; subtidal to $52 \mathrm{~m}$.

Trapezia formosa Smith, 1869 (Figure 12K)

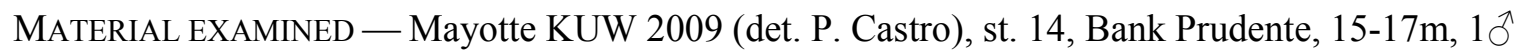
$5.7 \times 6.8 \mathrm{~mm}, 1$ ov. $5.5 \times 7.2 \mathrm{~mm}$, MNHN B32266, MNHN-IU-2009-1084.

OTHER RECORDS - Trapezia formosa - Castro, 1998: 180, Glorieuses, coll. A. Crosnier, J. Millot, $2 \widehat{\jmath}$, 1 , MNHN B25291. - Castro, 1999a: 110, Glorieuses.

GEOGRAPHIC AND DEPTH RANGES - IP, Kenya, Mayotte (present study), Mozambique to Clipperton, Gulf of California, Colombia, Equator; subtidal to $60 \mathrm{~m}$. A widespread species but still not reported in Hawaii and French Polynesia.

Trapezia guttata Rüppell, 1830 (Figure 12L)

MATERIAL EXAMINED - Mayotte KUW 2009 (det. P. Castro, J. Poupin), st. 12a, La Prévoyante Reef, 6-

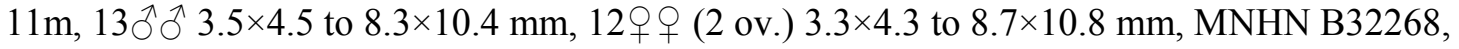
MNHN-IU-2009-1086; st. 14, field notes only, no specimens collected; st. 17, North Reef, 22m, 10 $6.3 \times 7.8 \mathrm{~mm}, 1$ ㅇ ov. $6.5 \times 8.0 \mathrm{~mm}$, MNHN B32269, MNHN-IU-2009-1087; st. 19, north Islet Handréma, 6-10m, 4 small specimens no collected; st 25, south Islet M'tzamboro, 15-20m, 1 ^ 4.5×5.5 mm, 1 ㅇ ov. $3.5 \times 4.5$ mm, MNHN B32270, MNHN-IU-2009-1088; st. 30, Rani Reef, double barrier, 3$15 \mathrm{~m}, 1 \delta^{\uparrow} 5.2 \times 6.5 \mathrm{~mm}, 1$ ov $5.6 \times 7.0 \mathrm{~mm}$, MNHN B32271, MNHN-IU-2009-1089; st. 32, northeast

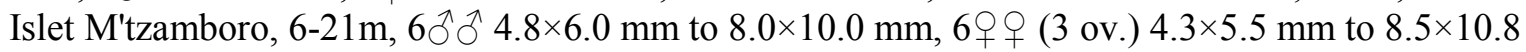
mm, MNHN B32272, MNHN-IU-2009-1090.

OTHER RECORDS - Trapezia guttata - Castro, 1999a: 110, Mayotte, coll. Marie 1903.

GEOGRAPHIC AND DEPTH RANGES - IWP, Red Sea, Madagascar, Mozambique (Emmerson, 2016) to Japan, French Polynesia; subtidal to $66 \mathrm{~m}$. 
Trapezia lutea Castro, 1997 (Figure 12M)

MATERIAL EXAMINED - Mayotte KUW 2009 (det. P. Castro, J. Poupin), st. 11, 'Bouée bâbord Est de Kongo', $1-4 \mathrm{~m}, 1$ ○ $10.0 \times 12.2 \mathrm{~mm}$; 1 \% ov. $12.3 \times 15.3 \mathrm{~mm}$, MNHN B32273, MNHN-IU-2009-1091; st. 12a, La Prévoyante Reef, 6-11m, 1ठ 6.6×8.0 mm, MNHN B32274, MNHN-IU-2009-1092; st. 14, Bank Prudente, $15-17 \mathrm{~m}, 1$ q ov. $10.8 \times 12.8$ mm, MNHN-B32013, MNHN-IU-2009-935, $1 \delta^{\uparrow} 9.4 \times 11.4$

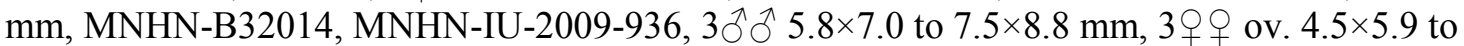

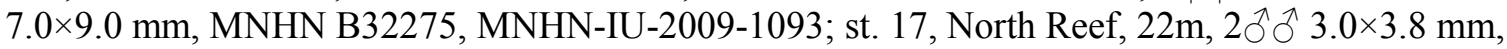
$4.5 \times 5.5 \mathrm{~mm}, 1$ + 4.4×5.4 mm, MNHN B32276, MNHN-IU-2009-1094; st. 23, Pass Choizil, 'Patate à Teddy', $15-30 \mathrm{~m}, 1$ q ov. $8.4 \times 9.0 \mathrm{~mm}$, MNHN-B32012, MNHN-IU-2009-934, 1 đ 5.9×7.2 mm, MNHN-B32015, MNHN-IU-2009-937, 1 đ 5.9×7.2 mm, MNHN-B32016, MNHN-IU-2009-938; st 25, south Islet M'tzamboro, 15-20m, $1 \overbrace{}^{\uparrow} 5.5 \times 6.7$ mm, MNHN B32277, MNHN-IU-2009-1095.

OTHER RECORDS - Trapezia lutea Castro, 1997: 85, Glorieuses, coll. A. Crosnier, January 1973, 1 ð, $3 ㅇ ㅜ$, MNHN-B 23046. - Castro, 1999a: 111, Glorieuses. - Poupin et al., 2013c: 11, Glorieuses.

REMARKS - This species can be confused with Trapezia bidentata. A distinguishing character is tomentum on the outer edge of the palm present in T. lutea and absent in T. bidentata.

GEOGRAPHIC AND DEPTH RANGES - IWP, Kenya, Mayotte (present study), South Africa to Guam, French Polynesia; subtidal to $45 \mathrm{~m}$.

Trapezia richtersi Galil and Lewinsohn, 1983 (Figure 12N)

MATERIAL EXAMINED - Mayotte KUW 2009 (det. P. Castro, J. Poupin), st. 12a, La Prévoyante Reef, 6$11 \mathrm{~m}, 1 \delta^{\Uparrow} 7.4 \times 8.6 \mathrm{~mm}, 1$ ov. $8.4 \times 10.8 \mathrm{~mm}$, MNHN B32278, MNHN-IU-2009-1096; st. 14, Bank

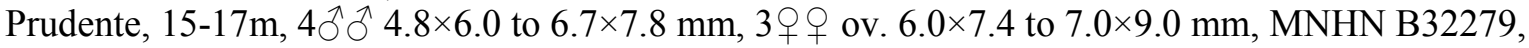

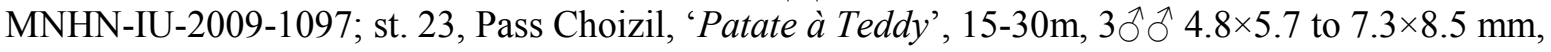
1 ov. 7.4×9.0 mm, MNHN B32280, MNHN-IU-2009-1098; st 25, south Islet M'tzamboro, 15-20m, 1 ㅇ 6.6×8.6 mm, MNHN B32281, MNHN-IU-2009-1099.

GEOGRAPHIC AND DEPTH RANGES - IO, Somalia, Mayotte (present study), Mozambique, Madagascar to Andaman Sea; subtidal to $52 \mathrm{~m}$.

Trapezia rufopunctata (Herbst, 1799) (Figure 13A)

MATERIAL EXAMINED - Mayotte KUW 2009 (det. P. Castro, J. Poupin), st. 8, 1ð 16.2×17.8 mm, MNHN B32123, MNHN-IU-2009-1042; st. 14, 1 ○ै $15.6 \times 17.4$ mm, 1 우 ov. $16.5 \times 19.5 \mathrm{~mm}, \mathrm{MNHN}$ B32124, MNHN-IU-2009-1043; st. 23, 1 ^ 14.3×16.1 mm (carapace damaged) MNHN B32125, MNHN-IU-2009-1044; st. 24, photo in situ, sp. not collected; st 25, $197.3 \times 9.3 \mathrm{~mm}$, MNHN B32126, MNHN-IU-2009-1045; st. 32, 1 ov. $15.2 \times 18.0$ mm, MNHN B32127, MNHN-IU-2009-1046.

OTHER RECORDS - Trapezia rufopunctata - Miers, 1884: 535, Glorieuses, coll. Coppinger, HMS Alert, in NHM. - Serène, 1984: 276, Mayotte, 10m, coll. A. Crosnier September 1959, 10 18.5×21.6 mm, MNHN-B 8260. - Castro, 1999a: 114, Mayotte, Glorieuses. - Poupin et al., 2013c: 11, Glorieuses.

GEOGRAPHIC AND DEPTH RANGES - IWP, Kenya, South Africa to Hawaii, French Polynesia; subtidal to $68 \mathrm{~m}$.

Trapezia tigrina Eydoux and Souleyet, 1842 (Figure 13B)

MATERIAL EXAMINED - Mayotte KUW 2009 (det. P. Castro, J. Poupin), st. 8, 1ð 10.8×12.0 mm, 1 ov.

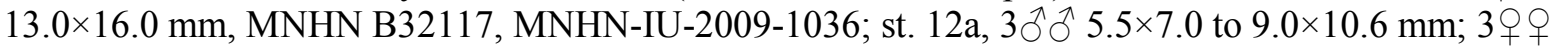
( 2 ov.) $4.0 \times 5.5$ to $10.6 \times 13.0 \mathrm{~mm}$, MNHN B32118, MNHN-IU-2009-1037; st. 14,1 ○ $11.2 \times 12.8 \mathrm{~mm}$, 1 + ov. $12.0 \times 14.4 \mathrm{~mm}$ (field det. J. Poupin as T. rufopunctata, corrected by P. Castro), MNHN B32119, MNHN-IU-2009-1038; st. 23, 1 స juv. 4.8×6.0 mm, MNHN B32120, MNHN-IU-2009-1039;

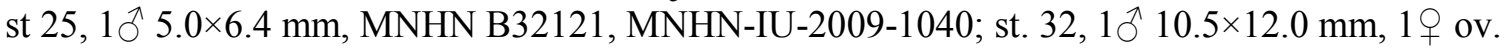
$12.5 \times 15.5 \mathrm{~mm}$ (field det. J. Poupin as T. rufopunctata, corrected by P. Castro), MNHN B32122, MNHN-IU-2009-1041. 
REMARKS - Several specimens were confused with Trapezia rufopunctata by J. Poupin during fieldwork. Peter Castro has determined these specimens and indicated (pers. comm.) that a good way to separate the two species is the aspect of the front, with low and rounded teeth in T. tigrina (vs. long and sharp teeth in T. rufopunctata).

GEOGRAPHIC AND DEPTH RANGES - IWP, Red Sea, Mozambique, Mayotte (present study) to Hawaii, French Polynesia, Pitcairn, ?Easter Island; subtidal to $75 \mathrm{~m}$.

\section{Superfamily Xanthoidea MacLeay, 1838}

\section{Family Xanthidae MacLeay, 1838}

Actaea spinosissima Borradaile, 1902 (Figure 13C)

MATERIAL EXAMINED - Mayotte KUW 2009, st. 12a, La Prévoyante Reef, 6-11m, 1 q 5.0×7.3 mm, MNHN B32282, MNHN-IU-2009-1100; st. 17, North Reef, 22m, 1 sp. 5.9×8.1 mm, MNHN-IU-20093221; st. 20b, Islet M'tzamboro, western reef flat, 10-15m, 1 ô 4×5.2 mm, MNHN-IU-2009-3223; st. 23, Pass Choizil 'Patate à Teddy', 15-30m, 1 đ̧ 4.8×6.5 mm, 1 ㅇ (+ Sacculina) 5.8 $\times 8.0 \mathrm{~mm}, \mathrm{MNHN}$ B32283, MNHN-IU-2009-1101; st. 25, Islet M'tzamboro, 15-20m, 1 † 5.6×7.7 mm, $1 \overbrace{}^{\Uparrow} 7.0 \times 9.3 \mathrm{~mm}$, MNHN-IU-2009-3220; st. 30, Rani Reef, double barrier, 3-15m, 1 § 5.0×7.0 mm, MNHN B32284, MNHN-IU-2009-1102.

REMARKS - These specimens were determined from Serène (1984). Size of the spines on the carapace is variable. Anterior lobe of region 3M (see Serène, 1984: 18, fig. C) is long and made of four tubercles. In the affiliated Actaea polyacantha (Heller, 1861), which is also found in Mayotte (see Appendix), this lobe is short.

GEOGRAPHIC AND DEPTH RANGES - IWP, Mayotte (present study), Cargados Carajos, Maldives to Australia (Torres Strait); intertidal, subtidal to $22 \mathrm{~m}$.

Actaeodes tomentosus (H. Milne Edwards, 1834) (Figure 13D)

MATERIAL EXAMINED - Mayotte KUW 2009, st. 26, low tide, intertidal, reef flat, Mutsumbatsou $1 \widehat{\jmath}$ juv. 6.8 $\times 10.7 \mathrm{~mm}, \mathrm{MNHN}$ B32285, MNHN-IU-2009-1103.

OTHER RECORDS - Actaea tomentosa - Lenz, 1910: 549, Mayotte. - Guinot, 1958a: 87, Mayotte, 19 $17 \times 11 \mathrm{~mm}, \mathrm{MNHN}$. - Guinot, 1967: 260, list with Mayotte. - Actaeodes tomentosus - Serène, 1984: 134, Glorieuses, Island du Lys, intertidal, coll. A. Crosnier 29 January 1971, 1ð $11 \times \mathrm{I} 7 \mathrm{~mm}, 4$ 우 largest $13.5 \times 20 \mathrm{~mm}$ MNHN-B6582. - Coll. Anker and Michonneau, 2008, Mayotte, st. MAY08-St1, Mboianatsa, UF13559.

GEOGRAPHIC AND DEPTH RANGES - IWP, Red Sea, South Africa to Hawaii, French Polynesia, intertidal, subtidal.

Atergatis floridus (Linnaeus, 1767) (Figure 13E)

MATERIAL EXAMINED - Mayotte KUW 2009, st. 12a, La Prévoyante Reef, 6-11m, 1 juv 3.4×5.1 mm, MNHN B32287, MNHN-IU-2009-1105.

OTHER RECORDS — Poupin et al., 2013c: 11, Glorieuses, 1 juv. MNHN-IU-2013-7337.

GEOGRAPHIC AND DEPTH RANGES - IWP, Red Sea, Mayotte (present study), Mozambique to Hawaii, French Polynesia, subtidal to $15 \mathrm{~m}$.

Banareia parvula (Krauss, 1843) (Figure 13F)

MATERIAL EXAMINED - Mayotte KUW 2009, st. 6, 'Déversoir Badamiers', intertidal, Petite Terre, $1{ }^{\wedge}$ $9.2 \times 12.3 \mathrm{~mm}, \mathrm{MNHN}-\mathrm{IU}-2009-2678$. 


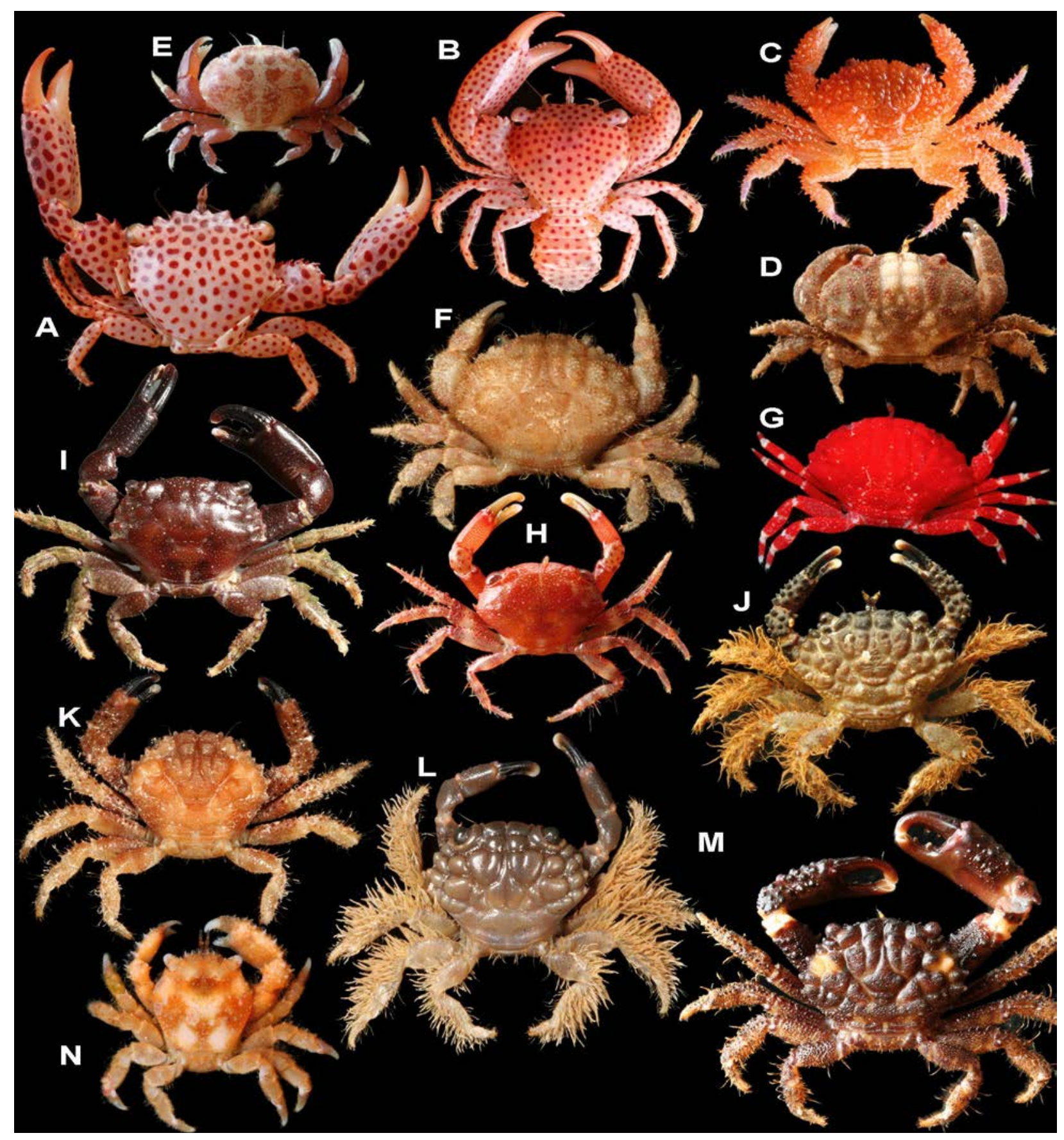

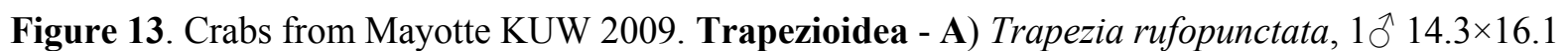
$\mathrm{mm}$ (posterior carapace broken), MNHN-IU-2009-1044; B) T. tigrina, 19 ov. $10.6 \times 13.0 \mathrm{~mm}, \mathrm{MNHN}-$ IU-2009-1037. Xanthidae - C) Actaea spinosissima, 1 9 5.0×7.3 mm, MNHN-IU-2009-1100; D) Actaeodes tomentosus, $1 \lesssim$ juv. $6.8 \times 10.7$ mm, MNHN-IU-2009-1103; E) Atergatis floridus, 1 juv $3.4 \times 5.1$

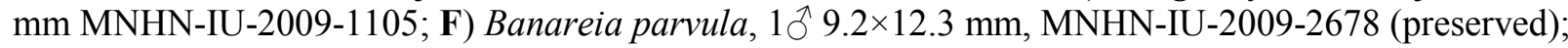
G) Bruciana pediger, 1 ㅇ 5.4×9.0 mm, MNHN-IU-2009-1150; H) Chlorodiella laevissima, 1 ㅇ $4.2 \times 7$ mm, MNHN-IU-2009-2662; I) C. nigra, 1ठ 10.1×14.7 mm, MNHN-IU-2009-1115; J) Cyclodius drachi, 1 7 7.43×10.74 mm, MNHN-IU-2009-1205; K) C. granulosus, 1 ○ 9.0×11.4 mm, MNHN-IU-2009-3238 (preserved); L) Cyclodius nitidus, 1 ㅇ 7.04×10.72 mm, MNHN-IU-2009-3239 (preserved); M) C. ungulatus, $1 \overbrace{}^{\Uparrow} 11 \times 14 \mathrm{~mm}$, MNHN-IU-2009-1206; N) Cymo deplanatus, $1 \overbrace{}^{\Uparrow} 7.0 \times 7.0 \mathrm{~mm}, \mathrm{MNHN}-\mathrm{IU}-$ 2009-1107. 
REMARKS - Male G1 is typical of Banareia species. It is attributed to B. parvula based on dorsal aspect of carapace, as described and figured in Serène (1984: 37, pl. IIIC): region 3M is entire and 2M is divided; outer face of chela is granulated which distinguishes it from B. armata A. Milne-Edwards, 1869 , also present in Mayotte, with outer face of palm smooth on ventral half.

GEOGRAPHIC AND DEPTH RANGES - IWP, Mayotte (present study), South Africa to Hawaii, French Polynesia, Easter Island; intertidal, subtidal

Bruciana pediger (Alcock, 1898) (Figure 13G)

MATERIAL EXAMINED - Mayotte KUW 2009, st. 14, Bank Prudente, 15-17m, 2 $q$ 5.4×9.0 mm, $3.5 \times 5.5$ mm, MNHN B32377, MNHN-IU-2009-1150.

REMARKS - These females were identified with confidence by the aspect of the carapace. Male characters in Serène (1984) cannot be verified: a) merus of cheliped exceeding the margin of carapace; and b) dactyl of cheliped with a noticeable tooth on its cutting edge.

GEOGRAPHIC AND DEPTH RANGES - IWP, Mayotte (present study), Seychelles to Philippines (Sulu Sea); $10-40 \mathrm{~m}$.

Chlorodiella laevissima (Dana, 1852) (Figure 13H)

MATERIAL EXAMINED - Mayotte KUW 2009, st. 12, La Prévoyante Reef, 6-11m, $2 \hat{\jmath} \hat{\jmath}, 1 q 3.4 \times 5.5$ mm, MNHN-IU-2009-2657; st. 14, Bank Prudente, 15-17m, 2 + $ᄋ$, MNHN-IU-2009-2661; st. 17, North Reef, 22m, 3 juv., MNHN-IU-2009-2663; st. 19, Islet Handréma, North, 6-10m,1 $4.2 \times 7$ mm,

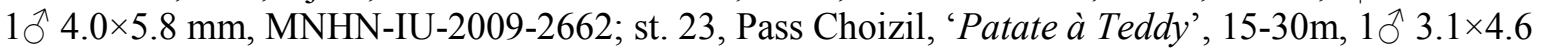
mm, MNHN-IU-2009-2659; 2 우 ov. both $3.1 \times 4.7 \mathrm{~mm}$, MNHN-IU-2009-2653; st. 25, south Islet M'tzamboro, 15-20m, 1 juv. 3.3×4.6 mm, MNHN-IU-2009-2658, 1 ^ 3.0×4.8 mm, MNHN-IU-2009-

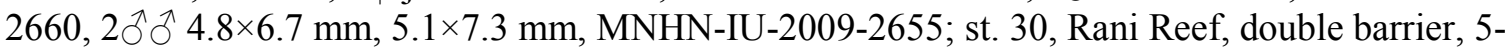
$15 \mathrm{~m}, 1$ + 4.9×7.5 mm, MNHN-IU-2009-2654; st. 35, Surprise Reef, Pass Longoni-M'tzamboro, 425m, 1 万 3.6×5.7 mm, MNHN-IU-2009-2656.

OTHER RECORDS - Chlorodiella laevissima - Guinot, 1964b: 71, Mayotte (in distribution). - Serène, 1984: 260, Glorieuses, intertidal, coll. A. Crosnier, September 1958, 2 ते $3.0 \times 4.6 \mathrm{~mm}, 4.3 \times 7.0 \mathrm{~mm}$, MNHN-B 6715; Mayotte, intertidal, coll. A. Crosnier, August 1959, 1 $\overbrace{}^{\Uparrow} 4.0 \times 6.4 \mathrm{~mm}$, MNHN-B 6716. - Coll. Anker and Michonneau, 2008, Mayotte, st. MAY08-St5, reef at S-shaped Pass, UFID 13611, 13627. - Poupin et al., 2013c: 11, Glorieuses.

REMARKS - A good character to identify this C. laevissima is the aspect of the anterolateral spines of the carapace: spines 1 and 4 reduced to tubercles, spine 2 is short and acute, spine 3 is the longest acute and hook shaped. The specimens examined include the two forms reported by Serène (1984): $C$. laevissima laevissima and C. laevissima robusta, accepted as synonyms in WoRMS (2018).

GEOGRAPHIC AND DEPTH RANGES - IWP, Somalia, Mozambique to Hawaii, French Polynesia; intertidal to $124 \mathrm{~m}$.

Chlorodiella nigra (Forskål, 1775) (Figure 13I)

MATERIAL EXAMINED - Mayotte KUW 2009, st. 3, fringing reef, Trévani, 1-8m, 1ठ 8.6×12.7 mm, 1 juv., MNHN B32470, MNHN-IU-2009-1232; st. 8, Lagoon close to Great North-Eastern Reef, $10^{\lambda}$ 10.1×14.7 mm, MNHN B32297, MNHN-IU-2009-1115; st. 19, north Islet Handréma, 1ठ 7.0×10.3

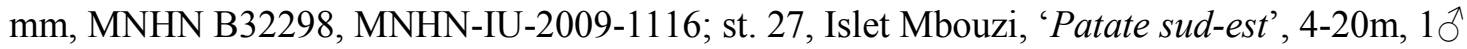
$9.0 \times 13.2 \mathrm{~mm}$, MNHN B32299, MNHN-IU-2009-1117; st. 30, Rani Reef, double barrier, 5-15m, $10^{\text {` }}$

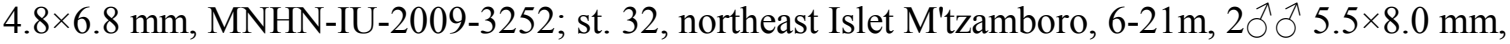
$7.3 \times 11.0 \mathrm{~mm} ; 3$ 우 $5.0 \times 7.2$ to $7.3 \times 10.6 \mathrm{~mm}$ (ov.), MNHN B32300, MNHN-IU-2009-1118.

OTHER RECORDS - Chlorodiella nigra - Guinot, 1958b: 180, Mayotte, $5 \bigcirc \hat{\jmath}, 2$, $q, 3$ juv., largest $18 \times 12$ mm, MNHN. - Guinot, 1967b: 262, list with Mayotte. - Coll. Anker and Michonneau, 2008, Mayotte, st. MAY08-St4, Sada, Tahiti beach, reef, UFID 13620. 
GEOGRAPHIC AND DEPTH RANGES — IWP, Red Sea, Mozambique to Japan, French Polynesia; intertidal to shallow-water.

Cyclodius drachi (Guinot, 1964b) (Figure 13J)

MATERIAL EXAMINED - Mayotte KUW 2009, st. 28, east Islet Mbouini, 3-20m, $197.43 \times 10.74$ mm, MNHN B32443, MNHN-IU-2009-1205.

OTHER RECORDS - Phymodius drachi - Serène, 1984: 249, Mayotte, intertidal, coll. A. Crosnier

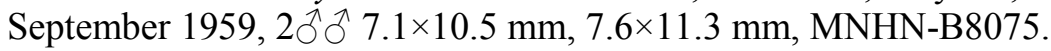

REMARKS - This species was confused in field notes with Cyclodius ungulatus (H. Milne Edwards, 1834). Consult Guinot (1964b) for species affiliated to Cyclodius drachi: C. ungulatus (H. Milne Edwards, 1834), C. granulatus (Targioni-Tozzetti, 1877) and C. nitidus (Dana, 1852).

GEOGRAPHIC AND DEPTH RANGES - IO, Red Sea, Kenya, Madagascar to Christmas Island (in Mendoza et al., 2014); intertidal, shallow subtidal.

Cyclodius granulosus De Man, 1888 (Figure 13K)

MATERIAL EXAMINED - Mayotte KUW 2009, st. 21b, Islet Choizil, east, Malandzamiayatsini, 15-20m, $1{ }^{\Uparrow} 9.0 \times 11.4 \mathrm{~mm}, 1$ + $8 \times 10 \mathrm{~mm}, 1$ juv., MNHN-IU-2009-3238; st. 23, Pass Choizil 'Patate à Teddy', 15-30m, 1 juv. 3.9×4.9 mm, MNHN-IU-2009-3243; st. 30, Rani Reef, double barrier, 3-15m, 1 juv. 4.2×5.3 mm, MNHN-IU-2009-3244.

OTHER RECORDS - Poupin et al., 2013c: 11, Glorieuses.

REMARKS - These specimens are similar to Cyclodius ungulatus. They are distinct by the male G1 as figured by Serène (1984, fig. 163): sub-distal setae oriented forward, instead of backward as in $C$. ungulatus. The determination of juveniles at st. 23, 30 is made with hesitation because without examination of mature male G1, C. ungulatus cannot be totally excluded. The presence of $C$. granulosus in Mayotte was suggested by Serène (1984) and is confirmed herein, with an additional record in Glorieuses by Poupin et al. (2013c).

GEOGRAPHIC AND DEPTH RANGES — IWP, Mayotte (present study), Madagascar to Japan, French Polynesia; intertidal to $15-30 \mathrm{~m}$ (present study).

Cyclodius nitidus (Dana, 1852) (Figure 13L)

MATERIAL EXAMINED - Mayotte KUW 2009, st. 26c, Mutsumbatsou reef flat, coll. J. -M. Bouchard 03/08/2008, intertidal 1 \% 7.04×10.72 mm, MNHN-IU-2009-3239; st. 26, Mutsumbatsou reef flat, intertidal $1 \hat{\jmath} 6.2 \times 8.8 \mathrm{~mm}, \mathrm{MNHN}-\mathrm{IU}-2009-3240$.

OTHER RECORDS - Phymodius nitidus - Serène, 1984: 249, Glorieuses, intertidal, coll. A. Crosnier 29

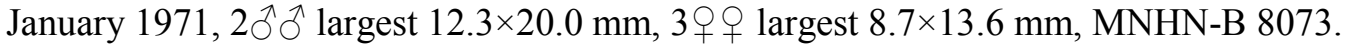

GEOGRAPHIC AND DEPTH RANGES - IWP, Red Sea, Tanzania, Mayotte (present study) to Hawaii, French Polynesia; intertidal, shallow subtidal.

Cyclodius ungulatus (H. Milne Edwards, 1834) (Figure 13M)

MATERIAL EXAMINED - Mayotte KUW 2009, st. 12, La Prévoyante Reef, 6-11m, 4 juv, MNHN-IU2009-3241; st. 19, north Islet Handréma, 6-10m, 1へ 11×14 mm, 1 sp. not measured, MNHN B32444,

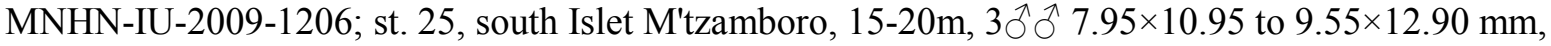
1 ○ึ $11.1 \times 15.1 \mathrm{~mm}, 1$ ㅇ $10.1 \times 14.1 \mathrm{~mm}, 3$ juv. MNHN-IU-2009-3242.

OTHER RECORDS - Phymodius ungulatus - Serène, 1984: 251, Glorieuses, Island du Lys, intertidal, coll.

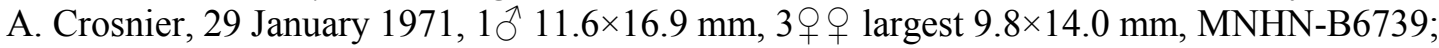

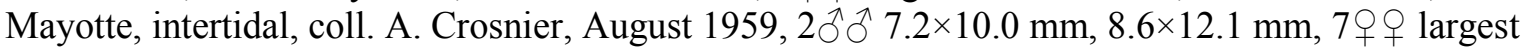
10.6×15.3 mm, MNHN-B8082. - Poupin et al., 2013c: 11, Glorieuses.

REMARKS - The specimens were determined by using Serène (1984: 247) key and these characters: a) carapace narrow $(\mathrm{CW} / \mathrm{CL}<1.5 \mathrm{~mm}) ; \mathrm{b})$ ambulatory legs with sparse setae; c) male abdomen with 
telson and $6^{\text {th }}$ segment as large as long; and d) male G1 with long distal setae, directed backward. Cyclodius ungulatus resembles C. obscurus but has sharper tubercles on the chelae (vs. tubercles reduced or absent in C. obscurus).

GEOGRAPHIC AND DEPTH RANGES - IWP, Red Sea, Mozambique to Hawaii, French Polynesia; intertidal to $15-20 \mathrm{~m}$ (present study).

Cymo deplanatus A. Milne-Edwards, 1873 (Figure 13N)

MATERIAL EXAMINED - Mayotte KUW 2009, st. 14, Bank Prudente, 15-17m, 1ठ 7.0×7.0 mm, MNHN

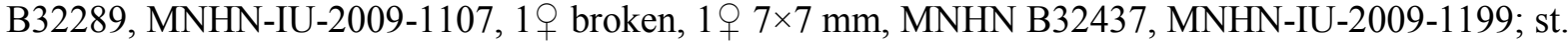
17, North Reef, 22m, 1 juv. (det. with hesitation), MNHN-IU-2009-2681; st. 21b, east Islet Choizil, Malandzamiayatsini, 15-20m, 1 \% 8.1×9.2 mm (det. with hesitation), MNHN-IU-2009-2680.

OTHER RECORDS - Cymo andreossyi - Guinot, 1958b: 181, Mayotte, in part not C. andreossyi (Audouin, 1826) cf. Serène (1984) - Cymo deplanatus - Serène, 1984: 33, Mayotte, from re-det. of Guinot (1958b) 'C. andreossyi'.

REMARKS - This species can be confused with C. andreossyi (Audouin, 1826). Determinations at st. 17 and $21 \mathrm{~b}$ with hesitation because of juvenile characters and resemblance with a specimen of $C$. melanodactylus at st. 30 (MNHN-IU-2009-1108, see below).

GEOGRAPHIC AND DEPTH RANGES - IWP, Somalia, Mayotte to French Polynesia; subtidal to at least 15$17 \mathrm{~m}$ (present study).

Cymo melanodactylus Dana, 1852 (Figure 14A)

MATERIAL EXAMINED - Mayotte KUW 2009, st. 8, lagoon near Great North-Eastern Reef, 6-8m, $1 \delta^{\wedge}$ $10.5 \times 12.5$ mm, MNHN B32442, MNHN-IU-2009-1204; st. 30, Rani Reef double barrier, 3-15m, 1 q $8.0 \times 8.9 \mathrm{~mm}, \mathrm{MNHN}$ B32290, MNHN-IU-2009-1108 (overall like $C$. deplanatus but attributed to $C$. melanodactylus because of black coloration of fingers of chelae instead of white in $C$. deplanatus; registered as Cymo sp. in MNHN in November 2017).

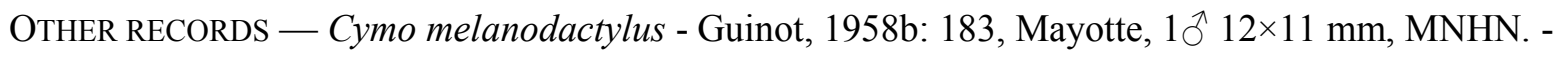
Guinot, 1967b: 263, list with Mayotte.

GEOGRAPHIC AND DEPTH RANGES - IWP, Red Sea, South Africa to Japan, Kiribati, French Polynesia; subtidal.

Cymo quadrilobatus Miers, 1884 (Figure 14B)

MATERIAL EXAMINED - Mayotte KUW 2009, st. 36, south Salizé beacon, coll. J. -M. Bouchard, 11/11/2008, 2m, 1 + 18.0×19.7 mm, MNHN B32454, MNHN-IU-2009-1216.

OTHER RECORDS - Cymo quadrilobatus - Guinot, 1958b: 183, Mayotte, $1015 \times 15 \mathrm{~mm}$, MNHN. Guinot, 1967b: 263, list with Mayotte. - Serène, 1984: 31, Mayotte, $1 ð 15 \times 15$ mm, MNHN.

GEOGRAPHIC AND DEPTH RANGES - IWP, Red Sea, South Africa to Guam, French Polynesia; subtidal.

Etisus anaglyptus H. Milne Edwards, 1834 (Figure 14C)

MATERIAL EXAMINED - Mayotte KUW 2009, st. 14, Bank Prudente, 15-17m, $1017.8 \times 25.5 \mathrm{~mm}$, MNHN B32466, MNHN-IU-2009-1228; st. 32, northeast Islet M'tzamboro, 6-21m, $1{ }^{\lambda} 9.5 \times 14 \mathrm{~mm}$, MNHN B32469 (see remarks); st. 33, Surprise Reef, Pass Longoni-M’tzamboro, 4-25m, 1 juv. $6.5 \times 8.4 \mathrm{~mm}, \mathrm{MNHN}-\mathrm{IU}-2009-2620$ (see remarks).

REMARKS - Specimens at stations 32 and 33 determined with hesitation (registered in MNHN collection as Etisus sp.; November 2017) but most probably juveniles of E. anaglyptus where granulation of chelipeds and first anterolateral spine of carapace are reduced.

GeOGRAPHIC AND DEPTH RANGES - IWP, Red Sea, Somalia, Mayotte (present study), South Africa to Japan, French Polynesia; shallow water to $30 \mathrm{~m}$. 
Etisus demani Odhner, 1925 (Figure 14D)

MATERIAL EXAMINED - Mayotte KUW 2009, st. 8, lagoon near Great North-Eastern Reef, 6-8m, $1 \delta^{\wedge}$ $6.6 \times 9.7 \mathrm{~mm}$ (with hesitation, male G1 not checked; E. odhneri Takeda, 1971 possible), MNHNB32381, MNHN-IU-2009-1154; st. 28, east Islet Mbouini, 3-20m, 1ðึ 11.4×16.8 mm, MNHN B32348, MNHN-IU-2009-1123.

OTHER RECORDS - Etisus demani - Serène, 1984: 227, Mayotte, intertidal, coll. A. Crosnier September

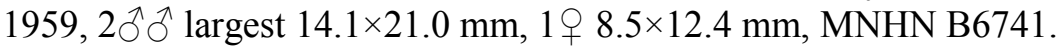

REMARKS - This species is related to E. odhneri Takeda, 1971 (also collected, see below). The characters of E. demani in Serène (1984) are verified on the largest specimen from st. 28 (MNHN-IU2009-1123): a) front aspect (compare fig. 143a, E. demani, and fig. 143b, E. odhneri, in Serène, 1984); b) anterolateral teeth of carapace with intercalated smaller teeth (absent or reduced in E. odhneri); c) dactyls of cheliped strongly curved distally; d) upper margin of ambulatory legs spinous; and e) aspect of male G1 with long sub-distal setae. On the smallest specimen examined, however, these characters are less obvious and differences with Etisus odhneri are more difficult to appreciate. Serène (1984: 227) has indicated that differences between these two species are perhaps size related questioning, therefore, the validity of E. odhneri.

GEOGRAPHIC AND DEPTH RANGES - IWP, Red Sea, Mayotte, Madagascar to Hawaii, French Polynesia; intertidal, subtidal to $120 \mathrm{~m}$.

Etisus dentatus (Herbst, 1785) (Figure 14E)

MATERIAL EXAMINED - Mayotte KUW 2009, st. 3, fringing reef, Trévani, at night, 1-8m, 1§ 67×103 mm, MNHN B32412, MNHN-IU-2009-1174.

REMARKS - This large Etisus can be confused with E. splendidus Rathbun, 1906. The two species are recognized by their live coloration, chocolate brown in E. dentatus (vs. bright red in E. splendidus), and by a single spine on the carpus of the cheliped in E. dentatus (vs. two spines in E. splendidus).

OTHER RECORDS - Poupin et al., 2013c: 11, Glorieuses.

GEOGRAPHIC AND DEPTH RANGES - IWP, Red Sea, Mayotte (present study), South Africa to Hawaii, French Polynesia; shallow water to $30 \mathrm{~m}$.

Etisus frontalis (Dana, 1852) (Figure 14F)

MATERIAL EXAMINED - Mayotte KUW 2009, st. 6, 'Déversoir Badamiers', intertidal, Petite Terre, $1 \delta^{\lambda}$ $10.7 \times 17.6 \mathrm{~mm}, 1$ ㅇ $7.8 \times 12.5 \mathrm{~mm}, 2$ juv., not located in MNHN; st. 19, north Islet Handréma, 6-10m, 1 ㅇ juv. $5.2 \times 6.8 \mathrm{~mm}, \mathrm{MNHN}-\mathrm{IU}-2009-2626$.

REMARKS - Male G1 has a coiled distal filament. In largest specimens the fixed finger of the larger chela has a molar tooth on its cutting edge, probably used to break mollusk shells. Juvenile at st. 19 is determined with hesitation and attributed to Etisus frontalis mostly because of the shape of its front (see illustration in Guinot, 1964b, pl. V, fig. 2; Serène, 1984, pl. XXXI E).

GEOGRAPHIC AND DEPTH RANGES - IWP, Mayotte (present study), Seychelles to ?Australia, French Polynesia; intertidal, subtidal. 


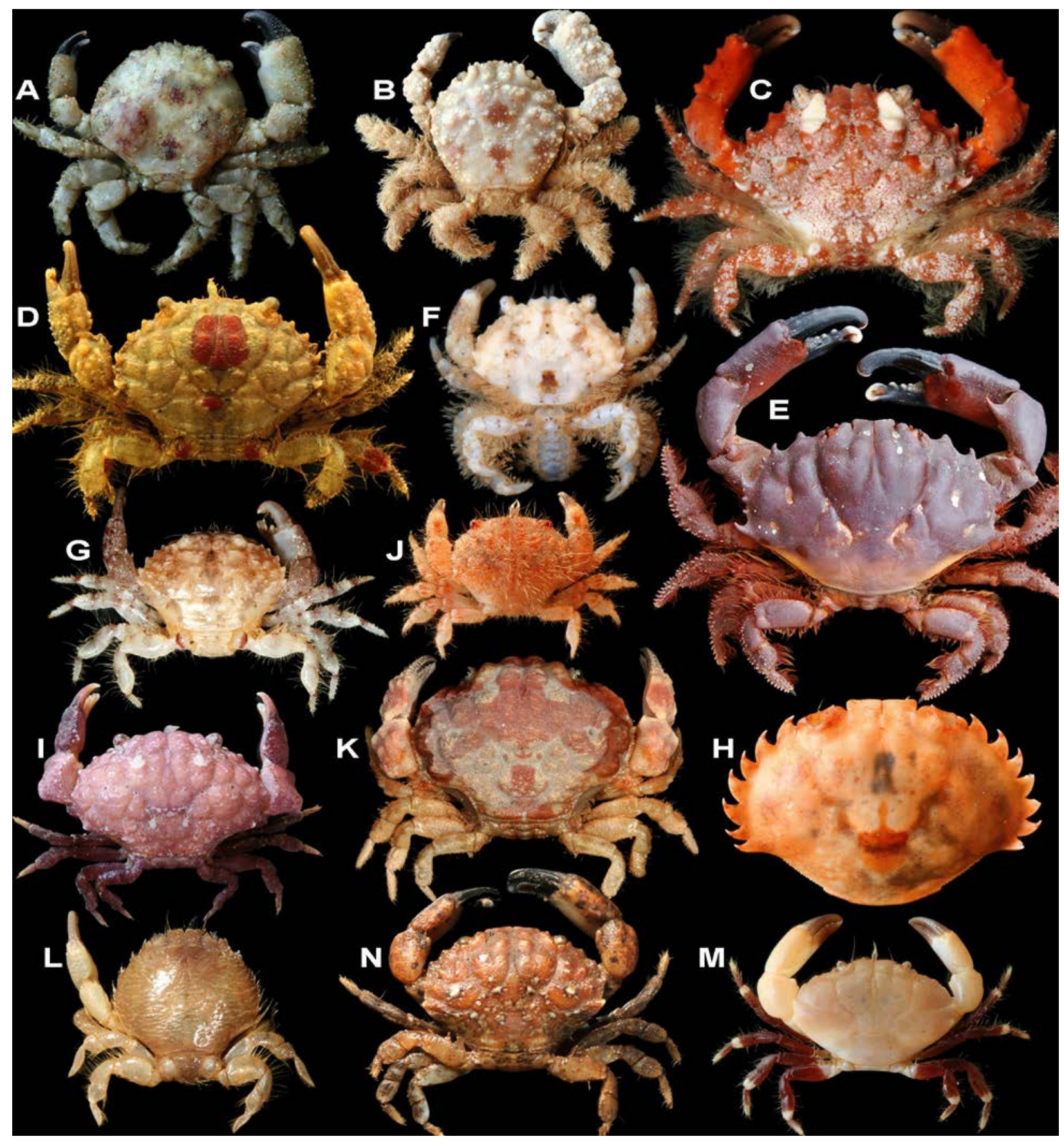

Figure 14. Crabs from Mayotte KUW 2009. Xanthidae - A) Cymo melanodactylus, $1 \lesssim 10.5 \times 12.5 \mathrm{~mm}$, MNHN-IU-2009-1204; B) Cymo quadrilobatus, 1 + 18×19.7 mm, MNHN-IU-2009-1216; C) Etisus

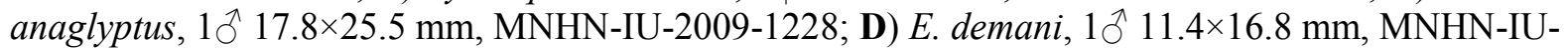
2009-1123; E) E. dentatus, $1 \bigcirc^{\Uparrow} 67 \times 103 \mathrm{~mm}$, MNHN-IU-2009-1174; F) E. frontalis, 1 + juv. $5.2 \times 6.8 \mathrm{~mm}$, MNHN-IU-2009-2626; G) E. odhneri, 1 + $6.6 \times 9.4$ mm, MNHN-IU-2009-2623; H) E. utilis, carapace $30.9 \times 47.6 \mathrm{~mm}$, MNHN-IU-2009-1249; I) Euxanthus exsculptus, $1{ }^{\top} 9.0 \times 13.7 \mathrm{~mm}$, MNHN-IU-20091111 ; J) Gaillardiellus rueppelli, 1 q juv. 5.0×6.8 mm, MNHN-IU-2009-1134; K) Hypocolpus

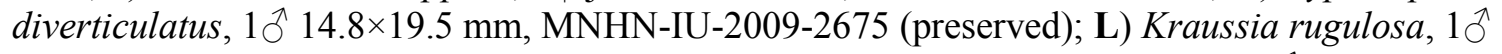
$11.3 \times 12.9$ mm, MNHN-IU-2009-3224 (preserved); M) Lachnopodus subacutus, $1 \delta^{\Uparrow} 7.4 \times 11.5 \mathrm{~mm}$, MNHN-IU-2009-1128; N) Leptodius exaratus, 10 10.2×14 mm MNHN-IU-2009-2615. 
Etisus odhneri Takeda, 1971 (Figure 14G)

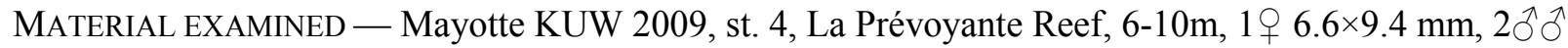
$5.6 \times 7.5 \mathrm{~mm}, 7.0 \times 9.7 \mathrm{~mm}, \mathrm{MNHN}-\mathrm{IU}-2009-2623$; st. 23, Pass Choizil, 'Patate à Teddy', $15-30 \mathrm{~m}, 1{ }^{\wedge}$ $7.4 \times 10.3 \mathrm{~mm}, \mathrm{MNHN}-\mathrm{IU}-2009-2625$; st. 25, south Islet M'tzamboro, $15-20 \mathrm{~m}, 1 \delta$ juv. $4.5 \times 6.2 \mathrm{~mm}$,

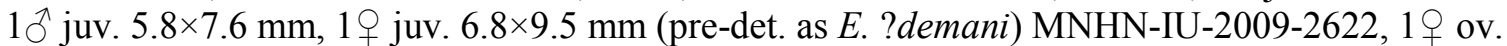
$7.3 \times 10.1 \mathrm{~mm}, 1$ 9 $9.7 \times 13.3 \mathrm{~mm}$, MNHN-IU-2009-2622; st. 33, seaside of Pass Longoni-M'tzamboro, 25m, $1 \overbrace{}^{\Uparrow} 6.3 \times 8.7 \mathrm{~mm}, \mathrm{MNHN}$ B32292, MNHN-IU-2009-1110 (pre-det. as E. ?demani); st. 35, Surprise Reef, Pass Longoni-M’tzamboro, 4-25m, 1 q 7.5×10.4 mm, MNHN-IU-2009-2621.

REMARKS - Etisus odhneri is similar to E. demani (see above). Specimens examined were attributed to E. odhneri from the original description of Takeda (1971) and the key and observations of Serène (1984). The following characters seem to be characteristic of E. odhneri: a) front more straight, without small lateral lobes; b) intercalated denticles between anterolateral teeth of carapace absent or reduced; and c) male G1 with a few short distal setae (several long distal setae in $E$. demani). The opinion of Serène (1984), however, that $E$. odhneri is perhaps a juvenile form of $E$. demani is supported by the largest specimen examined for E. odhneri $(199.7 \times 13.3 \mathrm{~mm}$, MNHN-IU-2009-2622) with characters intermediate between $E$. odhneri and $E$. demani (lateral lobes of front small but present; intercalated denticles between anterolateral teeth small but present). Live coloration of $E$. demani has often a remarkable large red patch on cardiac area, also observed on a few specimens of $E$. odhneri.

GEOGRAPHIC AND DEPTH RANGES - IWP, Kenya, Mayotte (present study) to Taiwan, Palau Islands, Australia (Coral Sea); subtidal.

\section{Etisus splendidus Rathbun, 1906}

MATERIAL EXAMINED - Mayotte KUW 2009, st. 32, northeast Islet M'tzamboro, 6-21m, carapace and one chela only, not collected.

OTHER RECORDS - Legall and Poupin (2018), Mayotte, in situ photo by Benjamin Pineau (specimen not collected).

REMARKS - This large Etisus is affiliated to E. dentatus (see above) and it can be recognized in the field by its bright red coloration (vs. brown in E. dentatus).

GEOGRAPHIC AND DEPTH RANGES — Red Sea, Mayotte (present study), Madagascar to Hawaii, French Polynesia; subtidal to at least $10 \mathrm{~m}$.

Etisus utilis Jacquinot, in Jacquinot and Lucas, 1853 (Figure 14H)

MATERIAL EXAMINED - Mayotte KUW 2009, st. 3, fringing reef, Trévani, night, photo in situ by. J. Dumas (in Legall and Poupin, 2018), 1-8m, not collected; st. 24, north Islet Handréma, 6-12m, carapace only $30.9 \times 47.6 \mathrm{~mm}, \mathrm{MNHN}$ B32487, MNHN-IU-2009-1249.

REMARKS - This Etisus is identifiable by the aspect of anterolateral margin of the carapace armed, behind the exorbital angle, with seven large teeth, curved and flattened, almost of equal size. Its live coloration is chocolate brown, as in E. dentatus.

GEOGRAPHIC AND DEPTH RANGES - IWP, Mayotte (present study), Madagascar to Japan, New Caledonia; intertidal, subtidal.

Euxanthus exsculptus (Herbst, 1790) (Figure 14I)

MATERIAL EXAMINED - Mayotte KUW 2009, st. 21b, east Islet Choizil, Malandzamiayatsini, 15-20m, 1 đ $9.0 \times 13.7$ mm, MNHN B32293, MNHN-IU-2009-1111.

OTHER RECORDS - Poupin et al., 2013c: 11, Glorieuses.

GEOGRAPHIC AND DEPTH RANGES - IWP, Mayotte (present study), Mozambique Channel (Juan de Nova), Mauritius to Japan, Guam, French Polynesia; subtidal to $15-20 \mathrm{~m}$. 
Gaillardiellus rueppelli (Krauss, 1843) (Figure 14J)

MATERIAL EXAMINED - Mayotte KUW 2009, st. 4, La Prévoyante Reef, 6-10m, 1 juv. (with hesitation), MNHN-IU-2009-2647; st. 20b, western reef, Islet M'tzamboro, 10-15m, 1 ^ $4.5 \times 5.7 \mathrm{~mm}, \mathrm{MNHN}-\mathrm{IU}-$ 2009-2646; st. 21b, east Islet Choizil, Malandzamiayatsini, 15-20m, $1+6.7 \times 9.5 \mathrm{~mm}, \mathrm{MNHN}-\mathrm{IU}-$ 2009-2650; st. 23, Pass Choizil, 'Patate à Teddy', 15-30m, 1 q 6.9×9.6 mm, MNHN-IU-2009-2645, $1{ }^{\Uparrow} 5.6 \times 7.7 \mathrm{~mm}, \mathrm{MNHN}-\mathrm{IU}-2009-2652$; st. 25, south Islet M'tzamboro, $15-20 \mathrm{~m}, 1$ juv. $3.7 \times 5.2 \mathrm{~mm}$, MNHN-IU-2009-2648, $2 \delta^{\top}$ and 2q $ᄋ$, MNHN-IU-2009-2649; st. 32, northeast Islet M'tzamboro, 6$21 \mathrm{~m}, 1$ q juv. $5.0 \times 6.8 \mathrm{~mm}$, MNHN B32361, MNHN-IU-2009-1134; st. 35, Surprise Reef, Pass Longoni-M'tzamboro, 4-25m, 1 § 6.8×9.2 mm, MNHN-IU-2009-2651.

OTHER RECORDS - Gaillardiellus rueppelli - Coll. Anker and Michonneau, 2008, st. MAY08-St1, Mboianatsa Reef, UFID 13570, 13575.

REMARKS - For photographs of this species see Guinot (1976: pl. 16, fig. 1, 1a) and Serène (1984: pl. XV F). Pollex black color extended variously, from distal part of palm only to about half of the palm.

GEOGRAPHIC AND DEPTH RANGES - IWP, Mozambique, Mayotte (present study), South Africa to Japan, Kiribati, French Polynesia; intertidal to $120 \mathrm{~m}$.

Hypocolpus diverticulatus (Strahl, 1861) (Figure 14K)

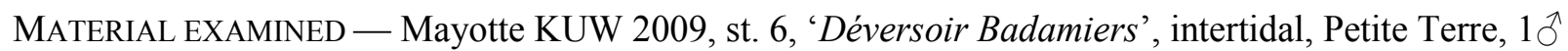
$14.8 \times 19.5 \mathrm{~mm}, \mathrm{MNHN}-\mathrm{IU}-2009-2675$.

OTHER RECORDS - Hypocolpus diverticulatus - Guinot, 1958a: 93, Mayotte, 1ठ 26×19 mm MNHN. Guinot-Dumortier, 1960: 180, Mayotte, same specimen. - Guinot, 1967b: 264, list with Mayotte.

REMARKS - According to Serène (1984: 90) this is 'l'espèce d'Hypocolpus la plus commune dans l'Océan Indien Occidental' with a specimen as large as $53 \times 74 \mathrm{~mm}$ reported.

GEOGRAPHIC AND DEPTH RANGES - IWP, Red Sea, Mozambique to Vietnam, Japan but mostly in WIO; intertidal.

Kraussia rugulosa (Krauss, 1843) (Figure 14L)

MATERIAL EXAMINED - Mayotte KUW 2009, coll. before fieldwork ?2008, V. Dinhut, seagrass bed Bouénie 'Sud, dans des résidus de carottage', 1ðત 11.3×12.9 mm, MNHN-IU-2009-3224.

OTHER RECORDS - Poupin et al., 2013c: 11, Glorieuses.

REMARKS - This crab has some resemblance with Palapedia integra (De Haan, 1835). Lateral margin of the carapace are denticulated with four salient acute spines (vs. feebly denticulated in $P$. integra) and the fingers of the chelae are slightly spoon shaped at tip (vs. acute at tip in P. integra). Serène (1972) can be consulted for key and photographs of both species.

GEOGRAPHIC AND DEPTH RANGES - IWP, Somalia, Mayotte (present study), South Africa to Japan, French Polynesia; intertidal, subtidal.

Lachnopodus subacutus (Stimpson, 1858) (Figure 14M)

MAterial EXAMINED - Mayotte KUW 2009, st. 34, 'Plage du Préfet', 2-8m, 1ð 7.4×11.5 mm, MNHN B32355, MNHN-IU-2009-1128.

REMARKS - This species has some resemblance with Liomera tristis. The specimen of L. subacutus collected at st. 34 was pre-determined in field notes as '?Liomera tristis (Dana, 1852)'. The same confusion was made by Lenz (1910) for a specimen of ' $L$. tristis' collected at Europa Island, later corrected in L. subacutus (cf. Serène, 1984: 59).

OTHER RECORDS - Lachnopodus subacutus - Serène, 1984: 205, Glorieuses, intertidal, coll. A. Crosnier 29 January 1971, 1 q 7.4×11.4 mm, MNHN-B 6666.

GEOGRAPHIC AND DEPTH RANGES - Red Sea, Mayotte (present study), Europa Island, Madagascar to Japan, Kiribati, Samoa; intertidal, subtidal. 
Leptodius exaratus (H. Milne Edwards, 1834) (Figure 14N)

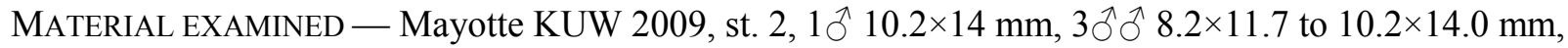
1 \% 8.1×11.7 mm, MNHN-IU-2009-2615; st. 6, 'Déversoir Badamiers', intertidal, Petite Terre, $1{ }^{\Uparrow}$ $8.5 \times 12.2 \mathrm{~mm}, 1$ q $8.5 \times 12.5$ mm, 3 juv., MNHN-IU-2009-2616; st. 10, east Islet 'Quatre Frères, Vatou', intertidal, 1 ○ิ $7.3 \times 10.4 \mathrm{~mm}$, MNHN-IU-2009-2618; st. 29, beach, intertidal at low tide, Mboianatsa, Ngouja Hotel, 14 spp., MNHN-IU-2009-2617.

OTHER RECORDS - Xantho (Leptodius) exaratus - Guinot, 1958a: 92, Mayotte, 1 ð $13 \times 19 \mathrm{~mm}, 1$ + 6.4×9 mm, MNHN. - Guinot, 1967b: 265, list with Mayotte. - Coll. Anker and Michonneau, 2008, Mayotte, st. MAY08-St7, Ngouja, reef, UFID 13632.

REMARKS - According to Serène (1984: 184) this is 'l'espèce de Xanthidae le plus commun de la zone intertidale de la région indo-pacifique tropicale. Sans grande difficulté, on peut en récolter des centaines d'exemplaires ... elle présente de nombreuses variations'. Several specimens listed herein were pre-identified in field notes as '?Leptodius sanguineus'. The two species are similar but can be separated with the key in Serène (1984): a) anterolateral margin of carapace with 4 teeth (L. exaratus) or 5 teeth, the fifth being sometimes indistinct (L. sanguineus); b) male G1 with 5-6 curved sub-distal spines in L. exaratus, absent in L. sanguineus. Male G1 of both species is figured in Serène (1984: 180, fig. 106-108).

GEOGRAPHIC AND DEPTH RANGES - WIO, Red Sea, South Africa to western coast of Indian; intertidal, shallow subtidal. In several contributions (e.g. Serène, 1984; Sakai, 2009; Castro, 2011) this species has a wide IWP distribution including Australia, Japan and Hawaii. Lee et al. (2013: 192), however, consider that $L$. exaratus s.s. is only in the WIO its eastern limit being western India.

\section{Leptodius gracilis (Dana, 1852)}

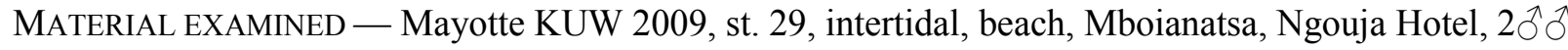
$4.6 \times 6.3 \mathrm{~mm}, 5.4 \times 7.3 \mathrm{~mm}, \mathrm{MNHN}-\mathrm{IU}-2009-2619$.

REMARKS - These specimens were collected with L. exaratus but are distinguished by: a) carapace smooth; b) anterolateral teeth of carapace rounded; c) shape of big chela as illustrated in Serène (1984: pl. 26C); d) aspect of male G1 (figures in Serène, 1984: 180, fig. 107, L. gracilis, and fig. 106, L. exaratus).

GEOGRAPHIC AND DEPTH RANGES - IWP, Red Sea, Mayotte (present study), Mozambique to Hawaii, French Polynesia; intertidal, shallow subtidal.

\section{Leptodius nudipes (Dana, 1852) (Figure 15A)}

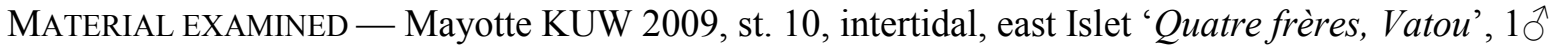
$7.9 \times 12.0 \mathrm{~mm}, 3$ ㅇ $9.2 \times 9.2$ to $7.0 \times 10.0 \mathrm{~mm}$ (first record, in error, as L. sanguineus), 1 ते $9.1 \times 13.8 \mathrm{~mm}$ (added in September 2011), MNHN B32346, MNHN-IU-2009-1121; st. 26, reef flat, intertidal, Mutsumbatsou, $196.4 \times 9.3 \mathrm{~mm}$, MNHN-IU-2009-2613; st. 26c, reef flat, intertidal, Mutsumbatsou, coll. J. -M. Bouchard 03/08/2008, $1 \delta^{\widehat{N}}$ (with Sacculina) 8.6×13 mm, ? 1 juv., MNHN-IU-2009-2614.

OTHER RECORDS - Leptodius nudipes - Serène, 1984: 183, Glorieuses, intertidal, coll. A. Crosnier, 16 September 1958, 2 रे गे $10.1 \times 15.1 \mathrm{~mm}, 11.3 \times 17.3 \mathrm{~mm}, 1$ ㅇ $8.1 \times 12.1 \mathrm{~mm}, \mathrm{MNHN}-\mathrm{B} 6636$.

REMARKS - This Leptodius species is unique by possessing a subdivision (bi or tri-cuspid) of the anterolateral carapace teeth.

GEOGRAPHIC AND DEPTH RANGES — IWP, Mayotte (present study), Mozambique Channel (Europa Island), Madagascar to Hawaii, New Caledonia; intertidal, shallow subtidal.

Leptodius sanguineus (H. Milne Edwards, 1834) (Figure 15B)

MATERIAL EXAMINED - Mayotte KUW 2009, st. 2, intertidal from Trévani to Kangani Mangrove, $2{ }^{\lambda} \sigma^{\lambda}$

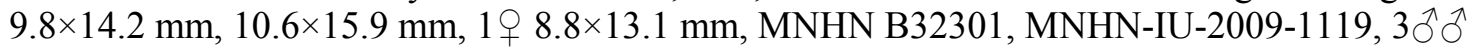
7.6×10.9 to $15.2 \times 23.7 \mathrm{~mm}, \mathrm{MNHN}$ B32345, MNHN-IU-2009-1120, 1 ๙ 9.1×13.4 mm, 6 우 (4 ov.) 
6.4×8.2 to $9.1 \times 13.4 \mathrm{~mm}, \mathrm{MNHN}-\mathrm{IU}-2009-3232$; st. 6, 'Déversoir Badamiers', intertidal, Petite Terre, 2 Љ $8.5 \times 12.3 \mathrm{~mm}, 15.5 \times 23.4 \mathrm{~mm}, 2$ ㅇ $8.5 \times 12.2 \mathrm{~mm}, 14.4 \times 21.5 \mathrm{~mm}, 3$ juv. (with hesitation),

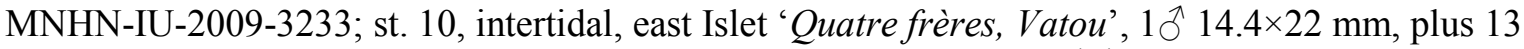

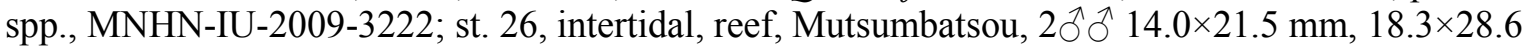
$\mathrm{mm}, 4$ 우 $6.5 \times 9.5$ (ov.) to $17.0 \times 26.4 \mathrm{~mm}$, MNHN B32347, MNHN-IU-2009-1122; st. 29, beach, intertidal low tide, Mboianatsa, Ngouja Hotel, $2 \widehat{\jmath}$, 1 juv., MNHN-IU-2009-3231.

OTHER RECORDS - Poupin et al., 2013c: 11, Glorieuses.

REMARKS - Live coloration of this species is extremely variable. At least three distinct color pattern are illustrated for Mayotte in Legall and Poupin (2018). Leptodius sanguineus can be confused with $L$. exaratus (differences are under L. exaratus).

GEOGRAPHIC AND DEPTH RANGES - IWP, Red Sea, Mayotte (present study), South Africa to Hawaii, French Polynesia; intertidal, shallow subtidal.

Linnaeoxantho acanthomerus (Rathbun, 1911) (Figure 15C)

MATERIAL EXAMINED - Mayotte KUW 2009, st. 19, Nord Islet Handréma, 6-10m, 1 q 5.8×8.1 mm, MNHN-IU-2013-7237.

REMARKS - The specimen examined matches well the characters and photograph in Rathbun (1911). A revision of this rare species is provided by Mendoza et al. (2012) with new records from Ryukyu and Kiribati (10-24 m). Melybia thalamita Stimpson, 1871 is the 'equivalent' species in WA, similar morphologically although assigned to a different genus. Phylogenetic analysis inferred from nuclear and mitochondrial markers indicate that both species should be classified in a separate family, Linnaeoxanthidae Števčić, 2005 (see Toma et al., 2014).

GEOGRAPHIC AND DEPTH RANGES - IWP, Mayotte (present study) to Japan, Kiribati; subtidal to 55m.

Liocarpilodes armiger (Nobili, 1905) (Figure 15D)

MATERIAL EXAMINED - Mayotte KUW 2009, st. 4, La Prévoyante Reef, 6-10m, 2ð̋ $\widehat{o} 2.9 \times 3.8$ mm, $3.5 \times 5.1 \mathrm{~mm}, 1+$ ov. $2.6 \times 3.9 \mathrm{~mm}, \mathrm{MNHN}-\mathrm{IU}-2009-2610$; st. 12, La Prévoyante Reef, 6-11m, 1 ㅇ $2.3 \times 3.7 \mathrm{~mm}, 1$ + $2.9 \times 4.2 \mathrm{~mm}, \mathrm{MNHN}-\mathrm{IU}-2009-2607$; st. 14 , Bank Prudente, $15-17 \mathrm{~m}, 1$ \% ov. $2.0 \times 4.6$ mm, 1 万ै, MNHN-IU-2009-2604; st. 17, North Reef, $22 \mathrm{~m}, 7$ juv. about $2.5 \times 3.5 \mathrm{~mm}$, MNHN-IU-2009-

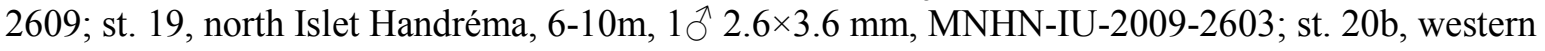
reef, Islet M'tzamboro, 10-15m, 2 spp., MNHN-IU-2009-2602; st. 23, Pass Choizil, 'Patate à Teddy', 15-30m, 1 ㅇ 2.4×3.6 mm, MNHN-IU-2009-2608; st. 25, south Islet M'tzamboro, 15-20m, 1 Љ $2.3 \times 4.5$ $\mathrm{mm}, 1$ + $3.15 \times 4.6 \mathrm{~mm}, \mathrm{MNHN}-\mathrm{IU}-2009-2605,19$ ov. $2.7 \times 3.9 \mathrm{~mm}, \mathrm{MNHN}-\mathrm{IU}-2009-2606$; st. 32, northeast Islet M'tzamboro, 6-21 m, $1 \overbrace{}^{\Uparrow} 2.6 \times 3.8 \mathrm{~mm}$, MNHN-IU-2009-2601.

OTHER RECORDS - Liocarpilodes armiger - Guinot, 1958b: 175, Mayotte, 1 ㅇ 5.0×3.5 mm MNHN. Guinot, 1967b: 265, list with Mayotte - Serène, 1984: 264, Glorieuses, 30m, coll. C. Jouannic, 1 July 1973, 1 9 2.5 $\times 3.0$ mm, MNHN-B 6723; Comoros (Anjouan), intertidal, coll. A. Crosnier, November 1961,1 ㅇ $2.7 \times 4.1 \mathrm{~mm}, \mathrm{MNHN}-\mathrm{B} 6725$.

REMARKS - The anterolateral margin of carapace is cut into four teeth, 1 and 4 being distinctly small or indistinct. There is a long and sharp spine on inner margin of the cheliped merus (close up macro photos are in Legall and Poupin, 2018).

GEOGRAPHIC AND DEPTH RANGES - WIO/?IWP, Red Sea, Mayotte, Mozambique Channel (Europa Island), Madagascar, Mauritius, perhaps to Guam, French Polynesia. The western population of $L$. armiger is sometimes attributed to the Pacific 'equivalent', L. pacificus Balss, 1938 (e.g. Davie, 2002) but Guinot (1958b) has mentioned morphological variations indicating that the two species are perhaps conspecific. 


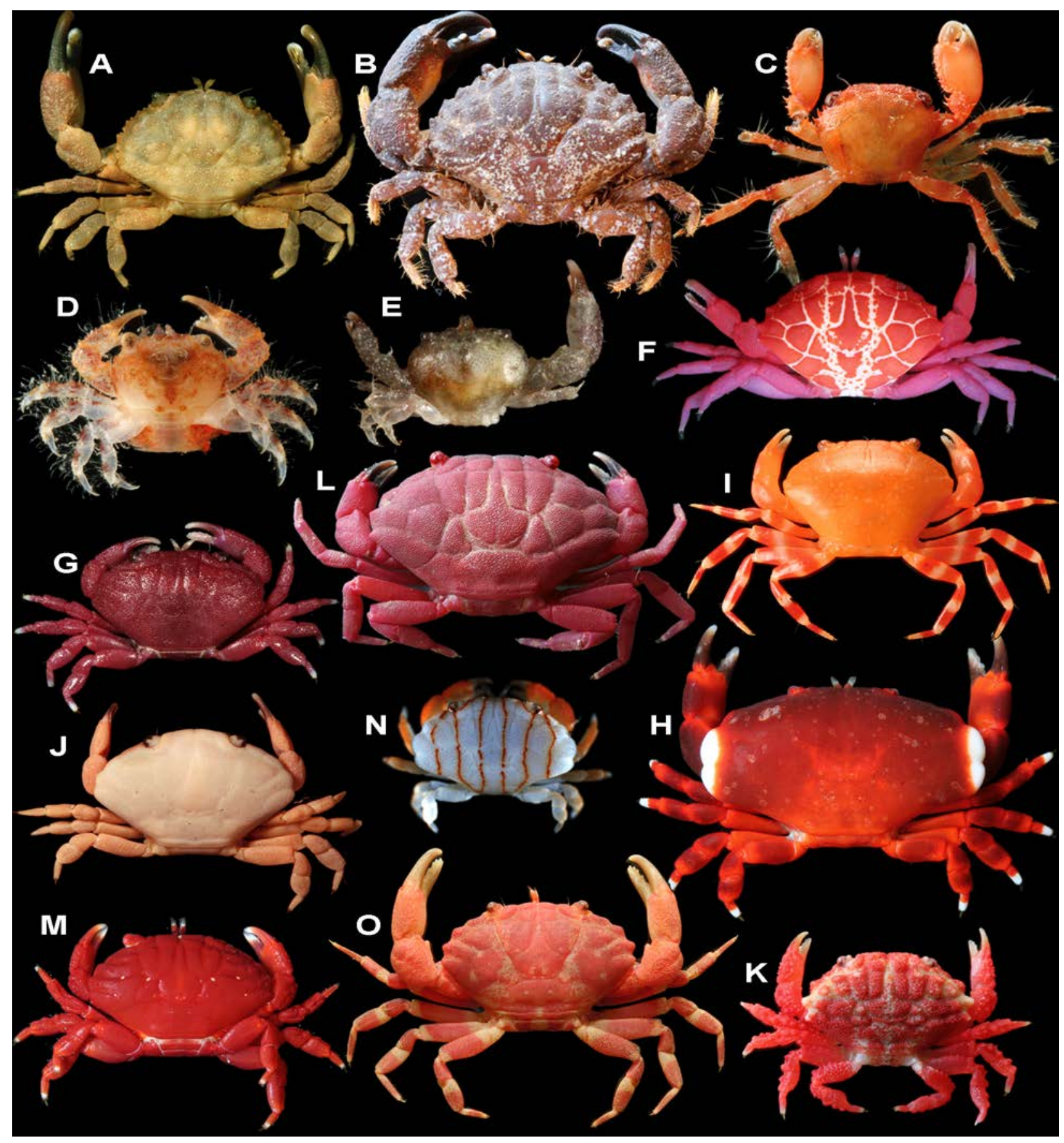

Figure 15. Crabs from Mayotte KUW 2009. Xanthidae - A) Leptodius nudipes, $1 ð 7.9 \times 12.0 \mathrm{~mm}$, MNHN-IU-2009-1121 (preserved); B) L. sanguineus, 1 ઈิ 14.4×22 mm, MNHN-IU-2009-3222; C) Linnaeoxantho acanthomerus, 1 \% 5.8 $\times 8.1 \mathrm{~mm}$, MNHN-IU-2013-7237; D) Liocarpilodes armiger, 1 q ov. $2.7 \times 3.9 \mathrm{~mm}, \mathrm{MNHN}-\mathrm{IU}-2009-2606$; E) L. integerrimus, 1 ठิ 2.3×3.2 mm, MHNH-IU-2013-7314 (from Glorieuses); F) Liomera albolineata, 1 q juv. 5.3×8.3 mm MNHN-IU-2009-1141; G) L. bella, 1 q 5.2×8,7 mm, MNHN-IU-2009-1145 (preserved); H) L. cinctimana, 1 ㅇ 10.4×19.2 mm, MNHN-IU-2009-1124; I) L. guttata, 1 + 7.2×11 mm, MNHN-IU-2009-1131; J) L. laevis, 1 \% $6.8 \times 11.3$ mm, MNHN-IU-2009-1149 (preserved); K) L. monticulosa, 1 ภ 3.8 $\times 6.4 \mathrm{~mm}$, MNHN-IU-2009-1125 (nb, color of carapace variable; totally white cream in some specimens); L) L. rubra, 1 \% $10.4 \times 17.0 \mathrm{~mm}$, MNHN-IU-2009-1147; M) $L$. stimpsoni, $1 \bigcirc 6.4 \times 10.7 \mathrm{~mm}$, MNHN-IU-2009-1142; N) L. striolata, specimen from Moorea, not measured, from Leray (2012, fig. C1-I); O) L. edwardsi, $1 \overbrace{}^{\Uparrow} 10.2 \times 17.0$ mm, MNHN-IU-2009-1127. 
Liomera albolineata (Serène and Nguyen, 1960) (Figure 15F)

MATERIAL EXAMINED - Mayotte KUW 2009, st. 23, 15-30m, 19 juv. 5.3×8.3 mm (live coloration

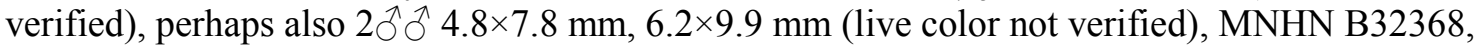
MNHN-IU-2009-1141.

REMARKS - These three specimens were registered as L. rubra in MNHN. The live color of 19 juv. $5.3 \times 8.3 \mathrm{~mm}$ presented herein, however, is clearly that of Liomera albolineata (Serène and Nguyen, 1960: pl. II, fig. A). This species has been little reported since its description despite its remarkable color pattern. A color photograph in Salvat and Bacchet (2011: 252, bottom left as 'Liomera cf. rubra') is obviously of L. albolineata, extending its distribution to French Polynesia (Moorea). Liomera albolineata is probably also in Japan, illustrated in color as ' $L$. rubra' in Kawamoto and Okuno (2003: 137, top).

GEOGRAPHIC AND DEPTH RANGES - IWP, Mayotte (present study, first record in IO) to Vietnam, Japan, French Polynesia; 15-20m.

Liomera bella (Dana, 1852) (Figure 15G)

MATERIAL EXAMINED - Mayotte KUW 2009, st. 10, east Islet 'Quatre frères, Vatou', intertidal, 19 $5.2 \times 8.7$ mm, MNHN B32372, MNHN-IU-2009-1145; st. 26, intertidal, Mutsumbatsou reef flat, coll. J. -M. Bouchard (Mliha), 2 đ̊ $3.5 \times 5.8 \mathrm{~mm}, 5.7 \times 9.3 \mathrm{~mm}, 2$ 우 $4.4 \times 7.4 \mathrm{~mm}, 5.7 \times 9.6 \mathrm{~mm}, \mathrm{MNHN}$ B32373, MNHN-IU-2009-1146.

OTHER RECORDS - Liomera bella - Serène, 1984: 61, Glorieuses, Island du Lys, intertidal, coll. A.

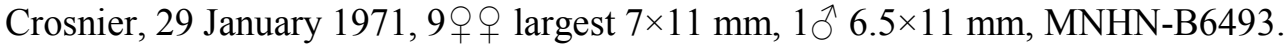

GEOGRAPHIC AND DEPTH RANGES - IWP, Red Sea, Mayotte (present study), Mozambique to Hawaii, French Polynesia; intertidal, subtidal.

Liomera cinctimana (White, 1847) (Figure 15H)

Material eXAmined - Mayotte KUW 2009, st. 23, Pass Choizil, 'Patate à Teddy', 15-30m, 1 q 10.4×19.2 mm, MNHN B32349, MNHN-IU-2009-1124.

OTHER RECORDS - Liomera cinctimana - Serène, 1984: 57, Glorieuses, Island du Lys, intertidal, coll. A. Crosnier 29 January 1971, 1 त 20.0×35.5 mm, intertidal, 30 January 1971, 1 우 36×65 mm, MNHNB6482. - Mayotte, buoy ${ }^{\circ} 8$ in S-shaped Pass, in situ photograph by Matthias Deuss, July 2011 (photo in Legall and Poupin, 2018).

GEOGRAPHIC AND DEPTH RANGES - IP, Red Sea, Mayotte (present study), South Africa to Gulf of California, Colombia; subtidal to $35 \mathrm{~m}$.

Liomera edwardsi Kossmann, 1877 (Figure 15O)

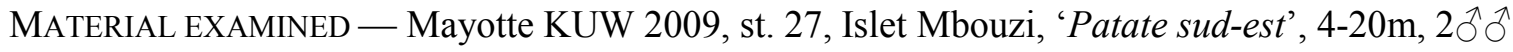
$9.0 \times 14.4 \mathrm{~mm}, 10.2 \times 17.0 \mathrm{~mm}, 1$ ㅇ $10.8 \times 17.6 \mathrm{~mm}, \mathrm{MNHN}$ B32354, MNHN-IU-2009-1127.

OTHER RECORDS - Serène, 1984: 58, Mayotte, 30m, coll. A. Crosnier March 1959, 1 q 4.6×7.0 mm, MNHN-B 8428.

REMARKS - These specimens were pre-identified as 'Liomera tristis' and recorded as such in MHNN. Liomera edwardsi and L. tristis are similar for the male G1 (illustrated for L. tristis in Serène, 1984: 48, fig. 19) and legs banded in white. They can be separated by: a) shape of carapace, less elongated $(\mathrm{CW} / \mathrm{CL} \sim 1.68)$ in L. edwardsi than in L. tristis $(\sim 1.76)$ with posterolateral margins straight making an angle of about $45^{\circ}$ with horizontal line of posterior margin (less than $45^{\circ}$ in L. tristis); b) anterolateral teeth of the carapace angular in L. edwardsi versus rounded in L. tristis; and c) dactyls of ambulatory legs much longer in $L$. edwardsi, length of P5 dactyl being included $\sim 3.55$ times in carapace length, versus $\sim 5.9$ in L. tristis.

GEOGRAPHIC AND DEPTH RANGES — IWP, Red Sea, Mayotte, Madagascar to Japan, northern Australia; subtidal, $15-35 \mathrm{~m}$. 
Liomera guttata de Man, 1888 (Figure 15I)

MATERIAL EXAMINED - Mayotte KUW 2009, st. 35, Surprise Reef, Pass Longoni-M'tzamboro, 4-25m, $197.2 \times 11.0$ mm, MNHN B32358, MNHN-IU-2009-1131.

REMARKS - Liomera guttata de Man, 1888 has been described from Indonesia (Ambon) and seems to be known only by the type specimen, revised by Odhner (1925: 14, pl. 1, fig. 4) and listed with a '?' in $\mathrm{Ng}$ et al. (2008: 200). Its live coloration is illustrated herein for the first time with a bright orange carapace, with faint paler patches on posterior half, chelipeds orange, and ambulatory legs banded in white and red-orange. On the specimen examined, the carapace is smooth, strongly convex, only 1.53 as large as long ( 1.56 for the type specimen of L. guttata) instead of usually more than 1.6 in most Liomera species; fingers of chelipeds are slightly spoon-shaped at tip; ambulatory legs are longer than in most Liomera species with length of P4 about $1.1 \mathrm{CW}$ with dactyls sub-equal to, or slightly longer, than propodi and P4 merus 3.36 as long as large. According to De Man (1888) and Odhner (1925) L. guttata is affiliated to L. laevis which was the determination by using the key of Serène (1984) but the two species are distinct (compare Figure 15I, J). The morphology of L. guttata is rather apart within the genus which would probably justify its assignment to a new genus.

GEOGRAPHIC AND DEPTH RANGES - IWP, Mayotte (present study) to Indonesia (Ambon); subtidal.

Liomera laevis (A. Milne-Edwards, 1873) (Figure 15J)

MATERIAL EXAMINED - Mayotte KUW 2009, st. 26, Mutsumbatsou reef flat, coll. J. -M. Bouchard (Mliha), intertidal, 1 \% $6.8 \times 11.3 \mathrm{~mm}, \mathrm{MNHN}$ B32376, MNHN-IU-2009-1149.

REMARKS - Specimen determined with key in Serène (1984). Coloration presented herein is altered by preservative (Figure 15J). Unaltered live color is in Nagai and Nomura (1988: 154) carapace being cream and legs red-purple banded in white.

GEOGRAPHIC AND DEPTH RANGES — Red Sea, Mayotte (present study), Mauritius to Japan, French Polynesia; intertidal, subtidal.

Liomera monticulosa (A. Milne-Edwards, 1873) (Figure 15K)

MATERIAL EXAMINED - Mayotte KUW 2009, st. 12a, La Prévoyante Reef, 6-11m, 1 đ 3.8×6.4 mm, MNHN B32350, MNHN-IU-2009-1125; st. 17, North Reef, 22m, 1ठ 3.0×5.1 mm, MNHN B32379,

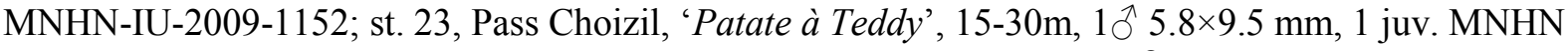
B32366, MNHN-IU-2009-1139; st. 25, south Islet M'tzamboro, 15-20m, 1 + 5.7×9.7 mm, MNHN B32367, MNHN-IU-2009-1140; st. 32, northeast Islet M'tzamboro, 6-21 m, $1 \overbrace{}^{\lambda} 4.2 \times 7.1 \mathrm{~mm}, \mathrm{MNHN}$ B32353, MNHN-IU-2009-1126.

OTHER RECORDS - Carpilodes caelatus - Guinot, 1958a: 86, Mayotte, 1 q $8 \times 5 \mathrm{~mm}, \mathrm{MNHN} / \mathrm{Not}$ Carpilodes caelata Odhner, 1925, corrected into L. monticulosa by Serène (1984) - Liomera monticulosa - Serène, 1984: 64, Mayotte, from Guinot, 1958a. - Coll. Anker and Michonneau, 2008, Mayotte, st. MAY08-St5, reef at S-shaped Pass, UFID 13636.

REMARKS - Live coloration of carapace varies from almost entire red to totally white cream, with intermediate aspects of mixed red and white cream patches (photographs in Legall and Poupin, 2018).

GEOGRAPHIC AND DEPTH RANGES - IWP, Red Sea, Kenya, Mayotte, Madagascar to Japan, French Polynesia, Easter Island; subtidal to about 80-120 m (maximum depth from unpublished observation in Austral Islands, French Polynesia, BENTHAUS Expedition, 2002, J. Poupin). 
Liomera rubra (A. Milne-Edwards, 1865) (Figure 15L)

MATERIAL EXAMINED - Mayotte KUW 2009, st. 8, lagoon near Great North-Eastern Reef, 6-8m, 19 $10.4 \times 17.0$ mm, MNHN B32374, MNHN-IU-2009-1147; st. 14, Bank Prudente, $15-17 \mathrm{~m}, 1 \mathrm{sp} .5 .4 \times 9$ $\mathrm{mm}$, not located in MNHN; st. 21b, east Islet Choizil, Malandzamiayatsini, 15-20m, 1 q ov. $11.4 \times 18.8$ mm, MNHN B32378, MNHN-IU-2009-1151; st. 23, 20 के 4.8×7.8 mm, 6.2×9.9 mm, MNHN B32368, MNHN-IU-2009-1141; st. 25, south Islet M'tzamboro, 15-20m, 1§ 11.2×18.2 mm, MNHN B32375, MNHN-IU-2009-1148; st. 35, 1 q 10.8×17.5 mm, MNHN B32356, MNHN-IU-2009-1129.

OTHER RECORDS - Liomera rubra - Serène, 1984: 65, Glorieuses, coll. A. Crosnier 29 January 1971, $1{ }^{\Uparrow}$ $9.0 \times 15.1 \mathrm{~mm}, \mathrm{MNHN}-\mathrm{B} 8427$.

GEOGRAPHIC AND DEPTH RANGES - IWP, Red Sea, Mayotte (present study), South Africa to Hawaii, French Polynesia; subtidal to $133 \mathrm{~m}$.

Liomera stimpsonii (A. Milne-Edwards, 1865) (Figure 15M)

Material eXAmined - Mayotte KUW 2009, st. 23, Pass Choizil, 'Patate à Teddy', 15-30m, $1 \delta^{\lambda}$ $6.4 \times 10.7$ mm MNHN B32369, MNHN-IU-2009-1142; st. 25, south Islet M'tzamboro, 15-20m, $10^{\Uparrow}$ $9.8 \times 16.7$ mm, MNHN B32370, MNHN-IU-2009-1143; st. 35, Surprise Reef, Pass LongoniM’tzamboro, 4-25m, 1ð 5.5×9.2 mm, MNHN B32371,MNHN-IU-2009-1144.

GEOGRAPHIC AND DEPTH RANGES - IWP, Somalia, Mayotte (present study), South Africa to Japan, French Polynesia; subtidal.

Liomera striolata (Odhner, 1925) (Figure 15N)

MATERIAl EXAMINED - Mayotte KUW 2009, st. 23, Pass Choizil 'Patate à Teddy', 15-30m, 1 juv. 3.1×5.4 mm, MNHN-IU-2009-3234.

REMARKS - This small specimen was identified as 'Liomera cf. semigranosa' in field notes and registered as such in MNHN. It was re-determined as L. striolata during this work based on the remains of coloration on the preserved specimen comprising six pale yellow longitudinal lines on carapace, two median lines behind either side of median sinus of the front and two lateral lines, the innermost being behind the orbit. Serène (1984) has indicated that this color pattern is distinctive of $L$. striolata. No color photograph being available for Mayotte, a specimen from French Polynesia is presented on Figure 15N (adapted from Leray, 2012).

GEOGRAPHIC AND DEPTH RANGES - IWP, Mayotte (present study), Seychelles to Japan, Guam, French Polynesia; subtidal.

Lophozozymus edwardsi Odhner, 1925 (Figure 16A)

MATERIAL EXAMINED - Mayotte KUW 2009, st. 30, Rani Reef, double barrier, 3-15m, $1 \overbrace{}^{\Uparrow} 24.8 \times 42.0$ mm, MNHN B32417, MNHN-IU-2009-1179.

REMARKS - This appears to be the first record of this species for the Indian Ocean record. The specimen from Mayotte has been compared with a specimen from New Caledonia in Paris collection (coll. Banaré, 1 đ 24.4×40.0 mm, MNHN B9324 [=B3011S, selected as lectotype in Guinot, 1979: 64], MNHN-IU-2014-22685. It matches also the photographs and description in Ng and Chia (1997) with: a) carapace glabrous; b) anterolateral margins cristate; c) large extension of pollex black coloration to the palm of chela, with a characteristic 'hook-shaped' form; and d) 'small orange punctuations all throughout the ventral surface'.

GEOGRAPHIC AND DEPTH RANGES — IWP, Mayotte (present study, first record in IO) to Guam, French Polynesia; subtidal.

Lophozozymus pulchellus A. Milne-Edwards, 1867 (Figure 16B)

MATERIAL EXAMINED - Mayotte KUW 2009, st. 35, Surprise Reef, Pass Longoni-M'tzamboro, 4-25m, $1{ }^{\top} 4.7 \times 7.6 \mathrm{~mm}$ (damaged), det. September 2011, MNHN-IU-2009-3237. 
REMARKS - Alive this small Lophozozymus has a reticulation of fine red lines on the carapace and its ambulatory legs are banded red. The specimen examined from KUW st. 35 is in a damaged condition, with only faint remains of live coloration. The live color pattern for Mayotte is nonetheless illustrated on Figure 16B from a photograph received during this work (courtesy N. Verneau). Live photos from French Polynesia (Legall and Poupin, 2018) are somewhat different indicating a possible complex of species.

GEOGRAPHIC AND DEPTH RANGES - IWP, Red Sea, Mayotte (present study), Tanzania to Guam, Hawaii, French Polynesia; shallow subtidal to $120 \mathrm{~m}$.

Lybia plumosa Barnard, 1947 (Figure 16C)

MATERIAL EXAMINED - Mayotte KUW 2009, st. 32, northeast Islet M'tzamboro, 6-21m, 1 ㅇ ov. 3.0×4.3 mm, MNHN B32434, MNHN-IU-2009-1196.

REMARKS - According to Guinot (1976) and Serène (1984) L. plumosa is similar to Lybia leptochelis (Zehntner, 1894), a species reported from Red Sea, Mozambique, Seychelles, Madagascar and Mauritius. Without comparative material, the specimen examined from Mayotte is nonetheless attributed to Lybia plumosa because of a faint tooth behind the two rounded lobes of anterolateral margin of the carapace ( $c f$. Serène, 1984, 27, key). Lybia plumosa is illustrated in color by Galil and Vannini (1990: 34, fig. 7b, Somalia) and L. leptochelis by Mendoza et al. (2014: 281, fig. 3E, Christmas Is.). The two species have a similar color pattern, suggesting that they are perhaps conspecific.

GEOGRAPHIC AND DEPTH RANGES - WIO (mostly) to IWP (unusual), Somalia, Mayotte (present study), South Africa to Seychelles, Madagascar, Mauritius; also French Polynesia; subtidal. This species is mostly in WIO records from the Pacific being limited to Moorea and Tikehau Islands, French Polynesia ( $c f$. Serène, 1984; Peyrot-Clausade 1989).

Lybia tessellata (Latreille, in Milbert, 1812) (Figure 16D)

MATERIAL EXAMINED - Mayotte KUW 2009, st. 5, seagrass bed near Great North-Eastern Reef, 1m, 1 q ov. $6.5 \times 8.3$ mm, MNHN B32430, MNHN-IU-2009-1192; st. 23, Pass Choizil, 'Patate à Teddy', 1530m, $2 \widehat{\jmath}, 1$ ㅇ ov. MNHN B32433, MNHN-IU-2009-1195; st. 25, south Islet M'tzamboro, 15-20m, 1 ㅇ $6.8 \times 7.9$ mm, MNHN B32431, MNHN-IU-2009-1193; st. 26, Mutsumbatsou reef flat, coll. J. -M. Bouchard st. Mliha 5-18m, 1q, 1 + ov., MNHN B32432, MNHN-IU-2009-1194.

OTHER RECORDS - Lybia tessellata - Serène, 1984: 28, Glorieuses, intertidal, coll. A. Crosnier, J. Millot, 16 September 1958, 11 spp. $4.6 \times 5.8$ to $8.3 \times 12.0 \mathrm{~mm}$, MNHN-B6691; Comoros (Anjouan) intertidal, coll. A. Crosnier, 1 juv. $3.5 \times 4.2 \mathrm{~mm}, 1$ q ov. $5.2 \times 7.2 \mathrm{~mm}$, MNHN-B 6690. - Coll. Anker and Michonneau, 2008, Mayotte, st. MAY08-St5, reef at S-shaped Pass, UFID 13683. - Photo Matthias Deuss, Mayotte, Sakouli, under a stone $1 \mathrm{~m}$ (in Legall and Poupin, 2018).

GEOGRAPHIC AND DEPTH RANGES - IWP, Red Sea, South Africa to Japan, Guam, French Polynesia; subtidal. All previous records of this species in Hawaii attributed to Lybia edmondsoni Takeda and Miyake, 1970 in Castro (2011: 100).

\section{Metaxanthops acutus Serène, 1984 (Figure 16E)}

MATERIAL EXAMINED - Mayotte KUW 2009, st. 17, North Reef, $22 \mathrm{~m}, 1$ q ov. $4.0 \times 5.1 \mathrm{~mm}$, MNHN-IU2009-3217; st. 32, northeast Islet M'tzamboro, 6-21m, 1 q juv. $3.2 \times 3.7 \mathrm{~mm}$, MNHN-IU-2009-3219; no station number, coll. V. Dinhut 1998, seagrass bed, Bouénie, 1 đ 7.1×9.8 mm, MNHN-IU-2009-3218.

OTHER RECORDS - Metaxanthops acutus - Serène, 1984: 214, Comoros (Anjouan), intertidal, coll. A. Crosnier, November 1961, 1 ㅇ 6.0×8.1 mm, paratype, MP-B6673. - Coll. Anker and Michonneau, 2008, Mayotte, st. MAY08-St5, reef at S-shaped Pass, UFID 136681.

GEOGRAPHIC AND DEPTH RANGES - IWP, Comoros (Anjouan), Mayotte (present study), Madagascar to New Caledonia (see Ng and Clark, 2002). 


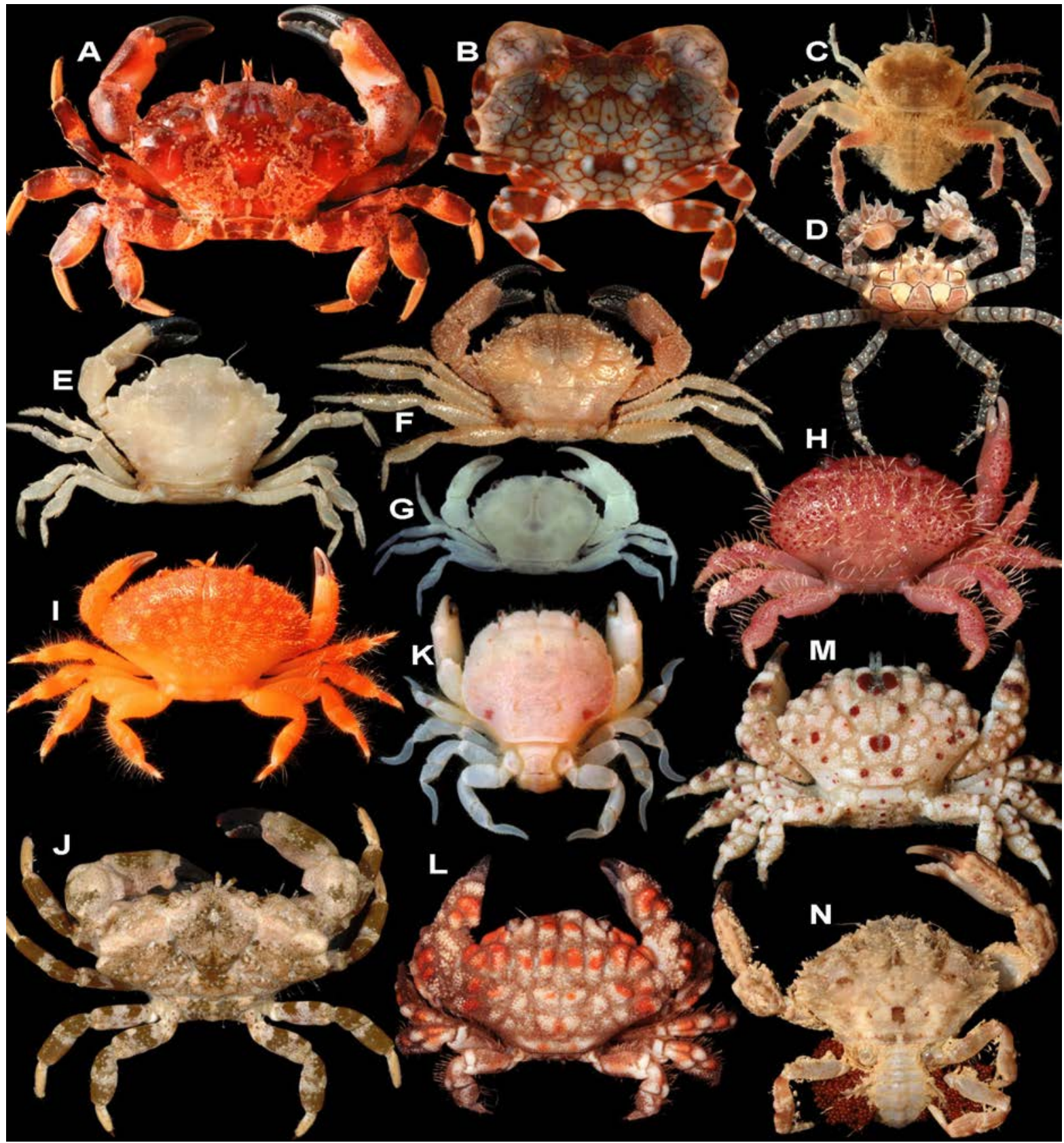

Figure 16. Crabs from Mayotte KUW 2009. Xanthidae - A) Lophozozymus edwardsi, $1 \overbrace{}^{\lambda} 24.8 \times 42 \mathrm{~mm}$, MNHN-IU-2009-1179; B) L. pulchellus, 1 specimen not measured (approximately $11 \times 18 \mathrm{~mm}$ ), not in MNHN photograph Norbert Verneau, Mayotte; C) Lybia plumosa, 1 ㅇ ov. $3.0 \times 4.3 \mathrm{~mm}, \mathrm{MNHN}-\mathrm{IU}-2009$ 1196 (dead specimen having lost the anemones fixed on its chelae when alive); D) Lybia tessellata, 19 ov. $6.5 \times 8.3 \mathrm{~mm}$, MNHN-IU-2009-1192 (with anemones on its chelae); E) Metaxanthops acutus, $1 \lesssim 7.1 \times 9.8$

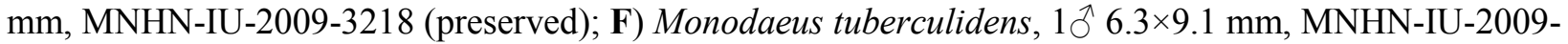
3235 (preserved); G) Nanocassiope alcocki, 1 q 3.5×5.2 mm, MNHN-IU-2009-2612 (preserved); H) Neoliomera sabaea, 1 ऊ 7.0×10.8 mm, MNHN-IU-2009-3229; I) N. themisto, $199.3 \times 16.0 \mathrm{~mm}$, MNHNIU-2009-1130; J) Neoxanthias impressus, Glorieuses 2012, photo M. Malay n ${ }^{\circ}$ MEPA1296, not measured about $30 \times 50 \mathrm{~mm}$; K) Palapedia integra, $199 \times 10 \mathrm{~mm}$, MNHN-IU-2009-3225; L) Paractaea retusa, $1 \delta^{\top}$ $12.5 \times 19.0 \mathrm{~mm}$, MNHN-IU-2009-3253 (preserved); M) Paractaea rufopunctata 1 ㅇ $12.0 \times 17.4 \mathrm{~mm}$, MNHN-IU-2009-1211; N) Paramedaeus octogesimus, 19 ov. 10.4×14.8 mm, MNHN-IU-2013-7354 (Glorieuses, 2012). 
Monodaeus tuberculidens (Rathbun, 1911) s.l. (Figure 16F)

MATERIAL EXAMINED - Mayotte KUW 2009, st. 19, north Islet Handréma, 6-10m, 1 đ 6.3×9.1 mm, MNHN-IU-2009-3235.

REMARKS - Guinot and Macpherson (1998) have revised several specimens of Monodaeus tuberculidens, including the type specimen from Saya de Malha Bank $(229 \mathrm{~m})$ and specimens from Réunion and Madagascar. They have reported morphological variations and attributed Réunion specimens to this species with hesitation ( $M$. aff. tuberculidens). They also indicate that records from Madagascar and South Africa must be revised to confirm $M$. tuberculidens. The specimen examined herein from Mayotte present most of the characters of $M$. tuberculidens listed in Guinot and Macpherson (1998) except for the armament of upper margins of P2-P5 meri, with spines instead of sharp granules for the holotype of $M$. tuberculidens. This difference is perhaps related to the small size of the specimen examined, $6.3 \times 9.1 \mathrm{~mm}$ (vs. $12.0 \times 18.2 \mathrm{~mm}$ for holotype). Due to remarks and observations in Guinot and Macpherson (1998) the present record from Mayotte is attributed to $M$. tuberculidens sensu lato. More specimens are required to understand the morphological variations in this species.

GEOGRAPHIC AND DEPTH RANGES - WIO, ?South Africa, ?Mayotte (present study), ?Madagascar, ?Réunion, Saya de Malha Bank; subtidal to 229m, ?420 m (Réunion).

Nanocassiope alcocki (Rathbun, 1902) (Figure 16G)

Material eXAmined - Mayotte KUW 2009, st. 23, Pass Choizil, 'Patate à Teddy', 15-30m, 1 ภ

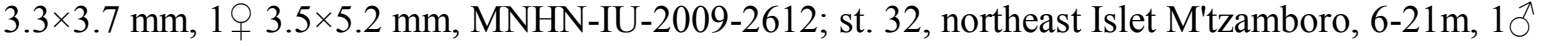
$3.0 \times 4.2 \mathrm{~mm}, \mathrm{MNHN}-\mathrm{IU}-2009-2611$.

REMARKS - The small specimens examined have juvenile characters with granules on chelipeds and carapace reduced, and anterolateral teeth of carapace low. The male G1, however, is similar to that of N. alcocki as figured by Serène (1984: 202).

GEOGRAPHIC AND DEPTH RANGES - IO, Seychelles, Mayotte (present study), South Africa to Maldives Islands, northwestern Australia (Ashmore and Cartier Islands), Christmas Island (see Mendoza et al., 2014); subtidal to $460 \mathrm{~m}$.

Neoliomera sabaea (Nobili, 1905) (Figure 16H)

MATERIAL EXAMINED - Mayotte KUW 2009, st. 25, southern tip Islet M'tzamboro, 15-20m, $1 \delta^{\Uparrow}$ $7.0 \times 10.8 \mathrm{~mm}, \mathrm{MNHN}-\mathrm{IU}-2009-3229$.

OTHER RECORDS - Neoliomera sabaea - Guinot, 1958a: 91, Mayotte, 1 + $16 \times 10 \mathrm{~mm}$, MNHN. - Actaea sabaea - Guinot, 1967b: 261, list with Mayotte. - Neoliomera sabaea - Serène, 1984: 69, Mayotte.

REMARKS - The specimen illustrated herein is slightly discolored due to preservation. For live color of N. sabaea see Galil and Vannini (1990, fig. 7E).

GEOGRAPHIC AND DEPTH RANGES - WIO, Red Sea, South Africa to Ceylon, Mauritius; intertidal, subtidal.

Neoliomera themisto (De Man, 1889) (Figure 16I)

MATERIAL EXAMINED - Mayotte KUW 2009, st. 35, Surprise Reef, Pass Longoni-M'tzamboro, 4-25m, 1 ऽิ $8.5 \times 13.8 \mathrm{~mm}, 1$ + $9.3 \times 16.0 \mathrm{~mm}, \mathrm{MNHN}$ B32357, MNHN-IU-2009-1130.

REMARKS - No comparison specimens were examined. The determination is made by a comparison with the photograph in Serène (1984, pl. IX A). Neoliomera themisto is affiliated to N. richtersi (De Man, 1889) distributed in the Pacific with similar live color pattern of orange punctuated with white patches (photo in Salvat and Bacchet, 2011). Serène (1984: 70) has suggested that the two species are perhaps conspecific.

GEOGRAPHIC AND DEPTH RANGES - WIO, Red Sea, Aldabra, Mayotte (present study); subtidal. 
Palapedia integra (De Haan, 1835) (Figure 16K)

MATERIAL EXAMINED - Mayotte KUW 2009, Mayotte, st. 14, Bank Prudente, 15-17m, 1 9×10 mm, MNHN-IU-2009-3225 (same sp. as 'P. marquesa (Serène, 1972)' in field report of Bouchard et al., 2009: 80).

REMARKS - This specimen was determined by using Serène (1972) key and description, most of the characters being those of $P$. integra, in particular, the front is sinuous vs. straight in the related $P$. bongensis (Serène, 1972), a species known from Philippines and Japan (see Ng, 1993: 153). In FLMNHN collection (UFID 13651) a specimen from Mayotte is identified as 'Palapedia bongensis'. This would be interesting to check this identification to verify that $P$. bongensis is present in Mayotte.

GEOGRAPHIC AND DEPTH RANGES - IWP, Mayotte (present study), Réunion, Mauritius to China, Japan, Gilbert Islands, ?Hawaii (questionable in Castro, 2011); shallow subtidal to $115 \mathrm{~m}$.

Paractaea retusa (Nobili, 1905) (Figure 16L)

Material eXAmined - Mayotte KUW 2009, st. 23, Pass Choizil, 'Patate à Teddy', 15-30m, 1 q $5.8 \times 7.9 \mathrm{~mm}, \mathrm{MNHN}-\mathrm{IU}-2009-3254$; st. 26c, Mutsumbatsou reef flat, coll. J. -M Bouchard

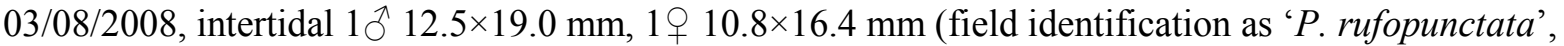
see remarks), MNHN-IU-2009-3253.

OTHER RECORDS - Paractaea retusa retusa - Serène, 1984: 125, Glorieuses, Island du Lys, intertidal; coll. A. Crosnier, 21 January 1971, 1 q 9.5×15.0 mm, MNHN-B6574.

REMARKS - This species can be confused with Paractaea rufopunctata, with the two species being collected together at station 26c. Paractaea retusa is characterized by: a) anterolateral margins of the carapace with only 3 lobes, the first one being fused with the exorbital angle (vs. 4 lobes in P.

rufopunctata); b) region 5L on carapace entire (vs. partly divided in P. rufopunctata); c) region 4L on carapace separated from ' $\mathrm{T}$ ' tooth (vs. connected to ' $\mathrm{T}$ ' tooth in P. rufopunctata; for nomenclature of carapace regions and teeth see Serène, 1984: 18, fig. C).

GEOGRAPHIC AND DEPTH RANGES - IWP, Red Sea, Kenya, Mayotte (present study), Mozambique Channel (Europa) to New Caledonia, French Polynesia; intertidal.

Paractaea rufopunctata (H. Milne Edwards, 1834) s.l. (Figure 16M)

MATERIAL EXAMINED - Mayotte KUW 2009, st. 3a, fringing reef, Trévani, 1-8m, 1 § 7.5×10.9 mm, MNHN-IU-2009-2669; st. 12c, La Prévoyante Reef at night, 6-11 m, $1 \lesssim 14.8 \times 30.3 \mathrm{~mm}, \mathrm{MNHN}$ B32446, MNHN-IU-2009-1208; st. 12a., 1 q juv. $4.6 \times 6.5 \mathrm{~mm}$ (with hesitation, $P$. retusa possible), MNHN-IU-2009-2673; st. 14, Bank Prudente, 15-17m, 1 ð 15.0×21.7 mm, MNHN B32286, MNHNIU-2009-1104; st. 20b, western reef flat, Islet M'tzamboro, 10-15m, 1 juv., MNHN-IU-2009-2672; st. 23, Pass Choizil, 'Patate à Teddy', 15-30m, 1 + 12.0×17.4 mm, MNHN B32449, MNHN-IU-2009$1211,1 \delta^{\Uparrow} 6.2 \times 9.4 \mathrm{~mm}, \mathrm{MNHN}-\mathrm{IU}-2009-2674$; st. 26, intertidal at low tide, Mutsumbatsou reef flat, $2{ }^{\Uparrow} \widehat{ }$ same size 17.2×24.0 mm, MNHN B32448, MNHN-IU-2009-1210; st. 26c, Mutsumbatsou reef

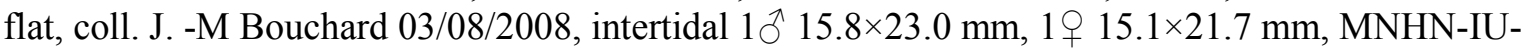
2009-2668; st. 27, Islet Mbouzi, 'Patate sud-est', 4-20m, 1 + 5.7×8.2 mm, MNHN-IU-2009-2667; st. 32, northeast, Islet M'tzamboro, 6-21 m, 1 q 14.8×21.0 mm, MNHN B32447, MNHN-IU-2009-1209; st. 35, Surprise Reef, Pass Longoni-M'tzamboro, 4-25m, $1+14.8 \times 20.9$ mm, MNHN-IU-2009-2670.

OTHER RECORDS - Paractaea rufopunctata f. frontalis nov. - Serène, 1984: 123, Mayotte, intertidal,

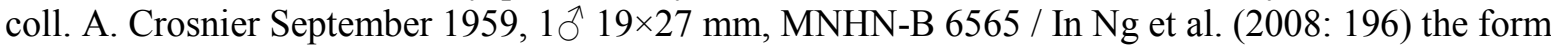
'frontalis' is not accepted.

REMARKS - Paractaea rufopunctata sensu lato is a species complex with several form identified by Serène (1984). Live coloration of specimens examined from Mayotte have a characteristic pattern of red or brown patches on carapace (see Figure 16M), with more photos in Legall and Poupin, 2018).

GEOGRAPHIC AND DEPTH RANGES - IWP, Red Sea, South Africa to Hawaii, French Polynesia; intertidal, subtidal. 
Pilodius areolatus (H. Milne Edwards, 1834) (Figure 17B)

MATERIAL EXAMINED - Mayotte KUW 2009, st. 5, seagrass bed, Great North-Eastern Reef, 1m, $1 \mathrm{sp.}$ $9.0 \times 11.6 \mathrm{~mm}$, MNHN-IU-2009-3246; st. 17, North Reef, $22 \mathrm{~m}, 1$ juv. not collected; st. 26, intertidal, Mutsumbatsou reef flat, $199.3 \times 13.7$ mm, 6 ㅇ ov., 2 juv., MNHN B32453, MNHN-IU-2009-1215, $1{ }^{7} 5.5 \times 7.2 \mathrm{~mm}, 1$ ㅇ $6.3 \times 8.7 \mathrm{~mm}$, MNHN-IU-2009-3248; st. 26c, Mutsumbatsou reef flat, coll. J. -M Bouchard 03/08/2008, 1 ㅇ 10.6×15.1 mm, MNHN-IU-2009-3247; st. 35, Surprise Reef, Pass LongoniM'tzamboro, 4-25m, 1 + 7.0×9.6 mm, MNHN-IU-2009-3245.

OTHER RECORDS - Chlorodopsis areolata - Guinot, 1958b: 176, Mayotte, 10 17×12 mm, MNHN. Pilodius areolatus - Guinot, 1967b: 268, list with Mayotte. - Serène, 1984: 236, Glorieuses, intertidal,

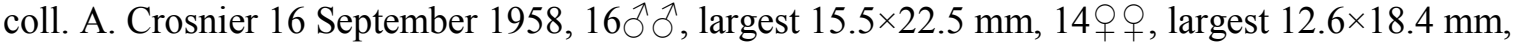

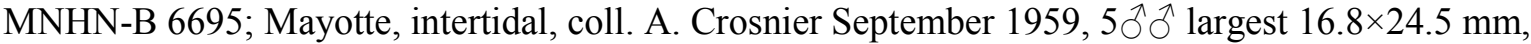
5 우 largest 11.4×16.5 mm, MNHN B-6694. - Coll. Anker and Michonneau, 2008, Mayotte, st. MAY08-St1, Mboianatsa, reef, UFID 13604; st. MAY08-St2, Tanaraki, reef, UFID 13553, 13555, 13564; st. MAY08-St0, UFID 20185. - Poupin et al., 2013c: 11, Glorieuses.

GEOGRAPHIC AND DEPTH RANGES — Red Sea, South Africa to Hawaii, French Polynesia; intertidal, shallow subtidal.

Pilodius spinipes (Heller, 1861) (Figure 17D)

MATERIAL EXAMINED - Mayotte KUW 2009, st. 4, La Prévoyante Reef, 6-10m, 8 spp. MNHN B32456,

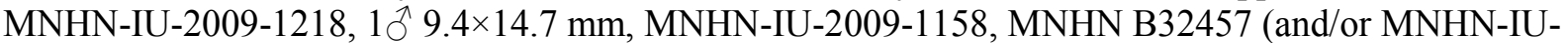
2009-1219); 2 juv. (with hesitation) MNHN-IU-2009-2637; st. 12, La Prévoyante Reef, 6-12m, 1 ㅇ $8 \times 13$ mm, 6 spp., MNHN B32458, MNHN-IU-2009-1220; st. 14, Bank Prudente, 15-17m, 11 spp., MNHN B32459, MNHN-IU-2009-1221, 5 o ${ }^{\lambda} 4.6 \times 7.0$ to $8.7 \times 13.2 \mathrm{~mm}, 6$ 우 $3.0 \times 5.0$ to $8.3 \times 12.5$

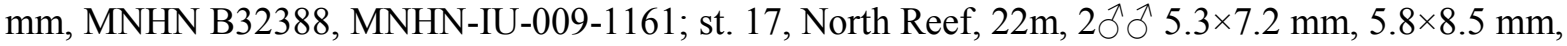
1 ㅇ $6.6 \times 9.2 \mathrm{~mm}, 1$ ㅇ ov. $7.1 \times 9 / 8 \mathrm{~mm}, 8$ juv. MNHN-IU-2009-2641; st. 20b, western reef Islet

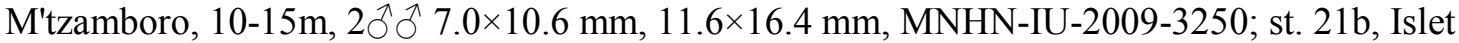
Choizil, east, Malandzamiayatsini, 15-20m, $1 \overbrace{}^{\Uparrow} 9.8 \times 14.0 \mathrm{~mm}$, MNHN-IU-2009-2639; st. 23, Pass Choizil 'Patate à Teddy', 15-30m, 2 + $96.7 \times 9.7 \mathrm{~mm}, 8.6 \times 12.9 \mathrm{~mm}$ (with hesitation), MNHN B32389, MNHN-IU-2009-1162, $1 \overbrace{}^{\Uparrow} 10.0 \times 13.5 \mathrm{~mm}$, MNHN-IU-2009-2635; st. 25, south Islet M'tzamboro, 15$20 \mathrm{~m}, 1$ juv. $3.4 \times 4.9 \mathrm{~mm}, 1 \bigcirc^{\wedge} 10.1 \times 15.4 \mathrm{~mm}, 1$ 9 $8.5 \times 13.3 \mathrm{~mm}$, MNHN-IU-2009-2638, 1 q $6.6 \times 9.6$ mm, MNHN-IU-2009-3249; st. 27, Islet Mbouzi, 'Patate sud-est', 4-20m, 1 sp. $8.0 \times 12.4 \mathrm{~mm}$, not

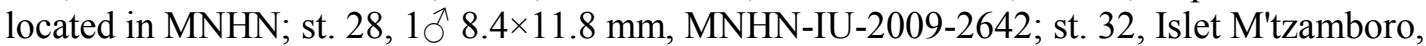
northeast; $6-21 \mathrm{~m}, 1 \delta^{\Uparrow} 7.5 \times 11.2 \mathrm{~mm}, 1$ + ov. $9.7 \times 14.1 \mathrm{~mm}, 2$ juv., MNHN-IU-2009-2636; st. 35,

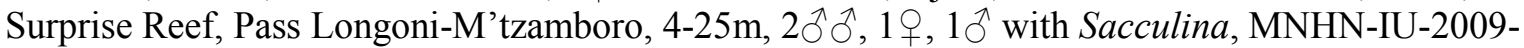
2640.

OTHER RECORDS - Chlorodopsis spinipes - Guinot, 1958b: 178, Mayotte, $1 ð 14 \times 9 \mathrm{~mm}$ MNHNB16505. - Pilodius spinipes - Guinot, 1967b: 268, list with Mayotte. - Clark and Galil, 1993: 1155,

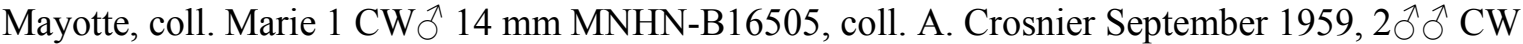
14.5-15.5 mm, 4우 CW 14-10 mm, MNHN-B8025. - Poupin et al., 2013c: 12, Glorieuses. - Pilodius aff. spinipes - Serène, 1984: 244, Glorieuses, intertidal, coll. A. Crosnier 29 January 1971, $1 \delta^{\lambda}$

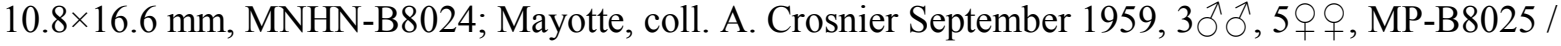
Accepted as P. spinipes in Clark and Galil (1993).

GEOGRAPHIC AND DEPTH RANGES - IO, Red Sea, Mozambique to Andaman, Mergui archipelagoes (see map in Clark and Galil, 1993, fig. 30); intertidal, subtidal.

Platypodia granulosa (Rüppell, 1830) (Figure 17E)

MATERIAL EXAMINED - Mayotte KUW 2009, st. 10, Islet 'Quatre frères, Vatou', intertidal, $1914 \times 20$ mm, MNHN B32445, MNHN-IU-2009-1207.

GEOGRAPHIC AND DEPTH RANGES - IWP, Red Sea, Mozambique, Mayotte (present study), South Africa to Hawaii, French Polynesia; intertidal, subtidal. 
Platypodia morini (Ward, 1942) (Figure 17F)

MATERIAL EXAMINED - Mayotte KUW 2009, st. 22, Islet Choizil, west, Malandzamiayajou, 30-35m, 1 ○ $12.3 \times 18.2$ mm, MNHN B32294, MNHN-IU-2009-1112.

REMARKS - This seems to be the first report of this species since Serène (1984). Figures can be consulted in Guinot (1964b, pl. I).

GEOGRAPHIC AND DEPTH RANGES — IO, Seychelles (Aldabra), Mayotte (present study) to Chagos Islands; shallow water to $42 \mathrm{~m}$.

Polydectus cupulifer (Latreille, in Milbert 1812) (Figure 17G)

MAterial EXAMINED - Mayotte KUW 2009, st. 23, Pass Choizil, 'Patate à Teddy', 15-30m, 1 q 5.0×5.5 mm, MNHN B32429, MNHN-IU-2009-1191.

REMARKS - This species is rarely reported despite a wide IWP distribution. The chelae hold anemones and has a typical shape as illustrated in Guinot (1976: 67-68, fig. 15a-g).

GEOGRAPHIC AND DEPTH RANGES - IWP, Red Sea, Mayotte (present study), Madagascar to Hawaii, French Polynesia; intertidal, subtidal to $15-30 \mathrm{~m}$.

Psaumis cavipes (Dana, 1852) (Figure 17H)

MATERIAL EXAMINED - Mayotte KUW 2009, st. 12, La Prévoyante Reef, 6-12m, 1 § 5.4×8.3 mm, MNHN B32441, MNHN-IU-2009-1203; st 25, south Islet M'tzamboro, 15-20m, 1 juv. $2.5 \times 3.7 \mathrm{~mm}$ MNHN-IU-2009-2677; st. 35, Surprise Reef, Pass Longoni-M'tzamboro, 4-25m, 1 ð 7.5×11.9 mm, MNHN-IU-2009-2676.

OTHER RECORDS - Actaea cavipes - Odhner, 1925: 68, Mayotte (specimens in Wien Museum). - Guinot, 1958a: 87, Mayotte, 1 ㅇ $13.0 \times 8.6 \mathrm{~mm}$, MNHN. - Guinot, 1967b: 260, list with Mayotte. - Psaumis cavipes - Serène, 1984: 129, Mayotte, coll. A. Crosnier September 1959, intertidal, $195 \times 8 \mathrm{~mm}$, lagoon, $50 \mathrm{~m}$ rubble and sand, $195.6 \times 8.5 \mathrm{~mm}$, MHNH-B6519; Comoros (Anjouan), intertidal, coll. A. Crosnier November, 1 + 4.1×6.7 mm, MNHN-B-6519. - Coll. Anker and Michonneau, 2008, Mayotte, st. MAY08-St1, Mboianatsa, reef, UFID 13663.

GEOGRAPHIC AND DEPTH RANGES - IWP, Red Sea, South Africa to Japan, Kiribati, French Polynesia; intertidal, subtidal.

Pseudactaea multicristata (Zehntner, 1894) (Figure 17I)

Material eXAmined - Mayotte KUW 2009, st. 23, Pass Choizil, 'Patate à Teddy', 15-30m, $1 \delta^{\lambda}$ 4.7×6.4 mm, MNHN-IU-2009-3236.

REMARKS - A rarely reported species.

GEOGRAPHIC AND DEPTH RANGES - IWP, Somalia (Galil and Vannini, 1990), Mayotte (present study), Madagascar to Vietnam, Indonesia; subtidal to $15-30 \mathrm{~m}$.

Pseudoliomera helleri (A. Milne-Edwards, 1865) (Figure 17J)

MATERIAL EXAMINED - Mayotte KUW 2009, st. 25, Islet M'tzamboro, south, 15-20m, $1 \overbrace{}^{\Uparrow} 11.35 \times 17.12$ mm, det. September 2011, MNHN-IU-2009-3228.

GEOGRAPHIC AND DEPTH RANGES - IWP, Red Sea, Somalia, Mayotte (present study), Madagascar to Japan, northern and western Australia; subtidal to $15-35 \mathrm{~m}$.

Pseudoliomera speciosa (Dana, 1852) (Figure 17K)

MATERIAL EXAMINED - Mayotte KUW 2009, st. 11, scraping of buoy 'Bâbord Est, Kongo' along shipping channel, 1-4m, 1 ○ 10.2×13.8 mm, 1, MNHN B32467, MNHN-IU-2009-1229; st. 23, Pass Choizil, 'Patate à Teddy', 15-30m, 1 q $8.5 \times 12.0$ mm, MNHN B32359, MNHN-IU-2009-1132; st. 32, northeast Islet M'tzamboro, 6-21m, 1 § 5.5×7.5 mm, MNHN B32360, MNHN-IU-2009-1133. 


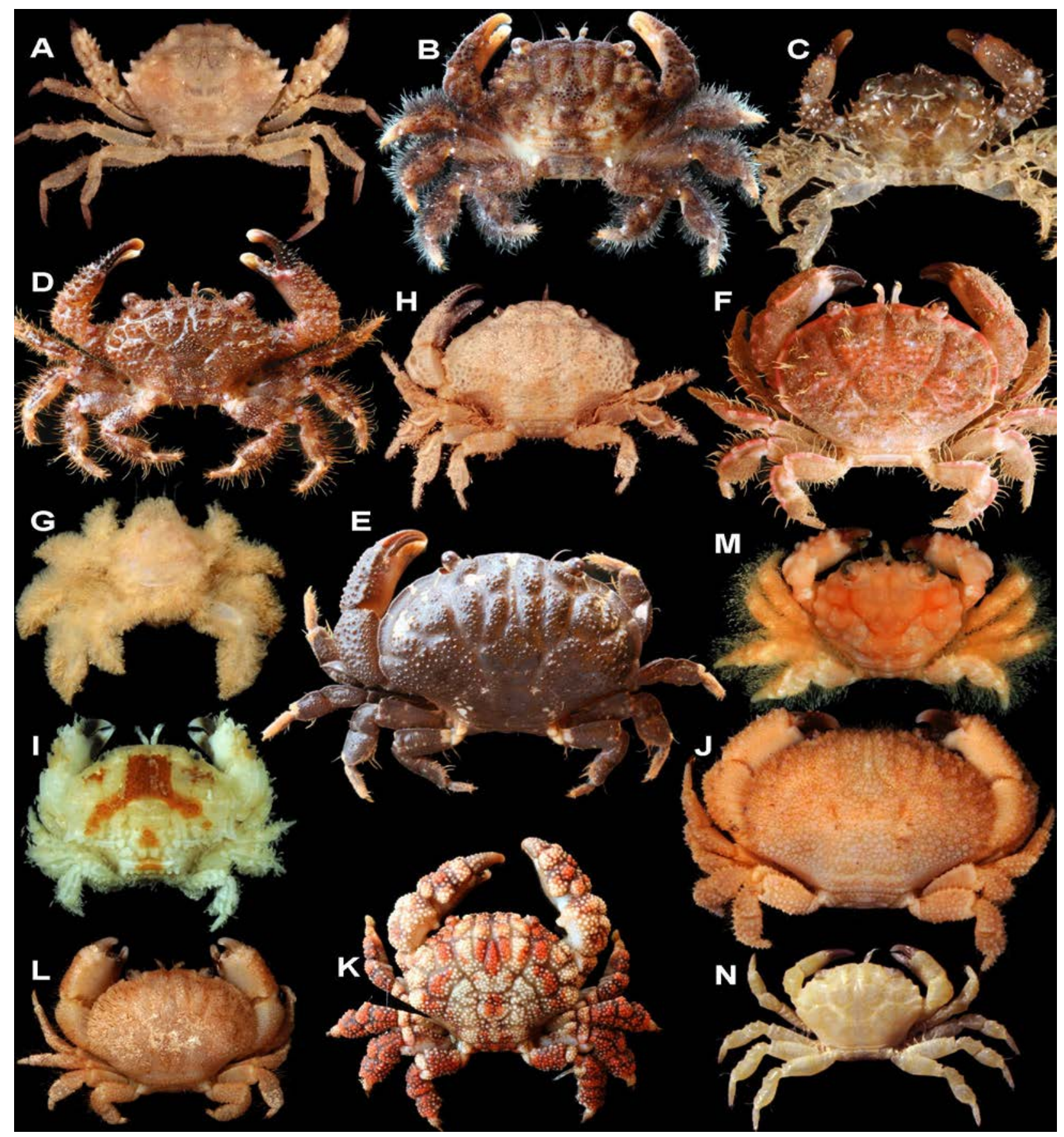

Figure 17. Crabs from Mayotte KUW 2009. Xanthidae - A) Paramedaeus simplex, 1 juv. $5.9 \times 7.8 \mathrm{~mm}$, MNHN-IU-2013-7355 (preserved; from Glorieuses, 2012); B) Pilodius areolatus, 1 sp. 9.0 $\times 11.6 \mathrm{~mm}$, MNHN-IU-2009-3246; C) P. pugil, 1 juv. not measured (CW about 7 mm), MNHN-IU-2013-7358 (from Glorieuses, 2012); D) P. spinipes, $198 \times 13 \mathrm{~mm}$, MNHN-IU-2009-1220; E) Platypodia granulosa, 1 + $14 \times 20$ mm, MNHN-IU-2009-1207; F) P. morini, 1 đ 12.3×18.2 mm, MNHN-IU-2009-1112; G) Polydectus cupulifer, 1 + $5.0 \times 5.5 \mathrm{~mm}$, MNHN-IU-2009-1191; H) Psaumis cavipes, $1 \delta^{\Uparrow} 7.5 \times 11.9 \mathrm{~mm}$, MNHN-IU-2009-2676 (preserved); I) Pseudactaea multicristata, $1 \overbrace{}^{\Uparrow} 4.7 \times 6.4 \mathrm{~mm}, \mathrm{MNHN}-\mathrm{IU}-2009-3236$ (preserved); J) Pseudoliomera helleri, 1 ^ 11.3×17.1 mm, MNHN-IU-2009-3228 (preserved); K) $P$. speciosa, 1 ○े 10.2×13.8 mm, MNHN-IU-2009-1229; L) P. variolosa, 1 ㅇ $7.4 \times 10.4 \mathrm{~mm}, \mathrm{MNHN}-\mathrm{IU}-$ 2009-3230 (preserved); M) Tweedieia laysani, $1 \overbrace{}^{\Uparrow} 6.8 \times 8.6 \mathrm{~mm}, \mathrm{MNHN}-\mathrm{IU}-2009-2679$ (preserved); N) Xanthias cherbonnieri, $1 \widehat{\overbrace{}} 3.05 \times 4.67 \mathrm{~mm}$, MNHN-IU-2009-2628 (preserved). 
GEOGRAPHIC AND DEPTH RANGES - IWP, Red Sea, Mayotte (present study), South Africa to Hawaii, French Polynesia; intertidal, subtidal.

Pseudoliomera variolosa (Borradaile, 1902) (Figure 17L)

Material eXAmined - Mayotte KUW 2009, st. 23, Pass Choizil, 'Patate à Teddy', 15-30m, 2 q $q$ $6.2 \times 9.2 \mathrm{~mm}, 7.4 \times 10.4 \mathrm{~mm}, \mathrm{MNHN}-\mathrm{IU}-2009-3230$.

REMARKS - This species has superficial resemblances with juveniles of Gaillardiellus rueppelli. The aspect of the chelae is a good distinguishing character; in Pseudoliomera variolosa the palm is more inflated and fingers are hook-shaped with two bristle brushes at tip (vs. not present in G. rueppelli).

GEOGRAPHIC AND DEPTH RANGES - IWP, Kenya, Somalia, Mayotte (present study), South Africa to Hawaii, French Polynesia; shallow subtidal to bathyal, 29-311m.

Tweedieia laysani (Rathbun, 1906) (Figure 17M)

MATERIAL EXAMINED - Mayotte KUW 2009, st. 25, south Islet M'tzamboro, 15-20m, $1 \overbrace{}^{\lambda} 6.8 \times 8.6 \mathrm{~mm}$, MNHN-IU-2009-2679.

OTHER RECORDS - Poupin et al., 2013c: 12, Glorieuses.

REMARKS - This species is related to Tweedieia odhneri (Gordon, 1934) distributed from Christmas Island to French Polynesia. Crosnier indicated (footnote, p. 253 in Serène, 1984) that the differences between the two species are not clear and in need of revision, 'compte tenu des variations individuelles'.

GEOGRAPHIC AND DEPTH RANGES - IWP, Seychelles (Aldabra), Mayotte (present study) to Hawaii, French Polynesia; intertidal, subtidal.

Xanthias cherbonnieri Guinot, 1964b (Figure 17N)

MATERIAL EXAMINED - Mayotte KUW 2009, st. 20b, western reef flat Islet M'tzamboro, 10-15m, 10 $4.4 \times 6.7 \mathrm{~mm}, \mathrm{MNHN}-\mathrm{IU}-2009-2629,1$ + $3.3 \times 5.2 \mathrm{~mm}$, MNHN-IU-2009-2631; st. 25, south Islet M'tzamboro, 15-20m, 1 ○ 3.05 $\times 4.67$ mm, MNHN-IU-2009-2628; st. 30, Rani Reef, double barrier, 3$15 \mathrm{~m}$ (with hesitation, see remarks), $195.5 \times 8.8 \mathrm{~mm}$, MNHN-IU-2009-2630.

REMARKS - This small species is characterized by a network of yellow lines on the carapace, illustrated in Guinot (1964, pl. II, fig. 1-4). Serène (1984) has indicated that the specimens collected at Réunion Island (20 m) were associated with a coral Galaxea fascicularis (Linnaeus, 1767). Xanthias cherbonnieri is rarely collected, probably because of its small size, but it has a wide IWP distribution. Mendoza et al. (2014) have reported X. cherbonnieri from Christmas Island but according to their photograph (Fig. 4E) this is probably a distinct species because the color pattern is atypical. In Mayotte KUW collection $195.5 \times 8.8 \mathrm{~mm}, \mathrm{MNHN}-\mathrm{IU}-2009-2630$ at st. 30 is different and attributed with hesitation to $X$. ?cherbonnieri. The aspect of the carapace is overall similar but the following differences were observed: a) much larger size; b) absence of reticulated pattern of yellow lines on carapace; c) presence of long fringes of setae on upper margins of meri of ambulatory legs (absent in $X$. cherbonnieri); d) both chelae of similar small size (vs. one chelae is larger than the other in $X$. cherbonnieri).

GEOGRAPHIC AND DEPTH RANGES - IWP, Seychelles (Aldabra), Mayotte (present study), Réunion to Japan; subtidal to $20 \mathrm{~m}$. 
Xanthias lamarckii (H. Milne Edwards, 1834) (Figure 19A)

MATERIAL EXAMINED - Mayotte KUW 2009, st. 26c, Mutsumbatsou reef flat, coll. J. -M Bouchard 03/08/2008, 1 q juv. 7.6×11.9 mm, MNHN-IU-2009-2627.

OTHER RECORDS - Xanthias lamarckii - Serène, 1984: 195, Comoros (Anjouan) intertidal, 1 $9.1 \times 14.4$ mm, MNHN-B6650. - Coll. Anker and Michonneau, 2008, Mayotte, st. MAY08-St2, Tanaraki, UFID 13592.

REMARKS - Serène (1984) indicates that this is 'l'espèce la plus commune du genre' but a single specimen was collected during KUW 2009. The Mayotte specimen being preserved is replaced in Figure 19A by material with clearer coloration (collection 2011, Europa Island, Poupin et al., 2013b).

GEOGRAPHIC AND DEPTH RANGES - IWP, Tanzania, Mayotte (present study), Mozambique, South Africa to Hawaii, French Polynesia; intertidal, subtidal.

Xanthias maculatus Sakai, 1961 s.l. (Figure 18A-D)

Material eXAMined - Mayotte KUW 2009, st. 23, Pass Choizil, 'Patate à Teddy', 15-30m, 1 q $3.7 \times 6.5 \mathrm{~mm}, 1 \jmath^{\uparrow} 5.0 \times 7.5 \mathrm{~mm}, \mathrm{MNHN}-\mathrm{IU}-2009-2633,1 q 5.9 \times 8.7 \mathrm{~mm}, 1$ juv. $4.1 \times 6.1 \mathrm{~mm}, \mathrm{MNHN}-$ IU-2009-2634; st. 25, south Islet M'tzamboro, 15-20m, 1 juv. 3.1×4.7 mm, MNHN-IU-2009-2632.

REMARKS - The 'ocellated' Xanthias include two species, X. maculatus and X. joanneae Mendoza, 2013 (see Mendoza, 2013). Mayotte specimens have intermediate characters between the two and, for this reason, are attributed to $X$. maculatus sensu lato. With $X$. joanneae they share: a) 31-33 ocelli on the carapace (at least 40 in $X$. joanneae vs. about 14 in $X$. maculatus); b) ambulatory legs with broad and stout meri, ratio of the width of the P5 merus to carapace length being 0.21 ( 0.22 in $X$. joanneae vs. 0.17 in $X$. maculatus). With $X$. maculatus they share: a) dorsal carapace region well demarcated, similar to holotype illustrated in Mendoza (2013, fig. 5A) (vs. not well demarcated in X. joanneae); b) teeth of anterolateral margin of carapace with acute apices (vs. rounded apices in $X$. joanneae, compare Mendoza, 2013: fig. 3A, 5A); c) external surface of the palm of the chelipeds with longitudinal ridges (vs. no ridges in $X$. joanneae). Serène (1984) has attributed several specimens from Kenya and 1 specimen from Vietnam to $X$. aff. maculatus because of teeth of anterolateral margin of carapace with rounded apices, merus of P5 stouter than in $X$. maculatus typical, and more ocelli on carapace (20 for Vietnamese specimen). He has suggested large intraspecific variations within $X$. maculatus, depending the locality. Mendoza (2013) has suggested that the Kenya specimens of Serène (1984) belong to a species distinct from either X. maculatus or X. joanneae. Intermediate characters observed in the present collection from Mayotte indicate that $X$. maculatus sensu lato is in need of revision to decide if this is a single species, with regional variations, or if more than two species must be considered in the 'ocellated' Xanthias.

GEOGRAPHIC AND DEPTH RANGES (for ocellated Xanthias: X. maculatus, X. joanneae) - IWP, Kenya, Mayotte (present study) to Philippines, Japan; subtidal to $85-110 \mathrm{~m}$.

Zosimus aeneus (Linnaeus, 1758) (Figure 19B)

MATERIAL EXAMINED - Mayotte KUW 2009, st. 26, Mutsumbatsou reef flat, $1 \delta 41 \times 61 \mathrm{~mm}$, MNHN B32403, MNHN-IU-2009-1165; st. 26c, same, coll. J. -M. Bouchard, 1 q $35 \times 51$ mm, 2 juv., MNHN B32404, MNHN-IU-2009-1166.

OTHER RECORDS - Zosimus aeneus - Serène, 1984: 165, Glorieuses, intertidal, under coral blocks, coll. A. Crosnier 16/9/1958, $9 \widehat{\diamond} \widehat{\jmath}$ largest $53 \times 80 \mathrm{~mm}, 3$ 우 largest $46 \times 68 \mathrm{~mm}, \mathrm{MNHN}$.

GEOGRAPHIC AND DEPTH RANGES - IWP, Red Sea, Mayotte (present study), South Africa to Hawaii, French Polynesia; intertidal, shallow subtidal. 


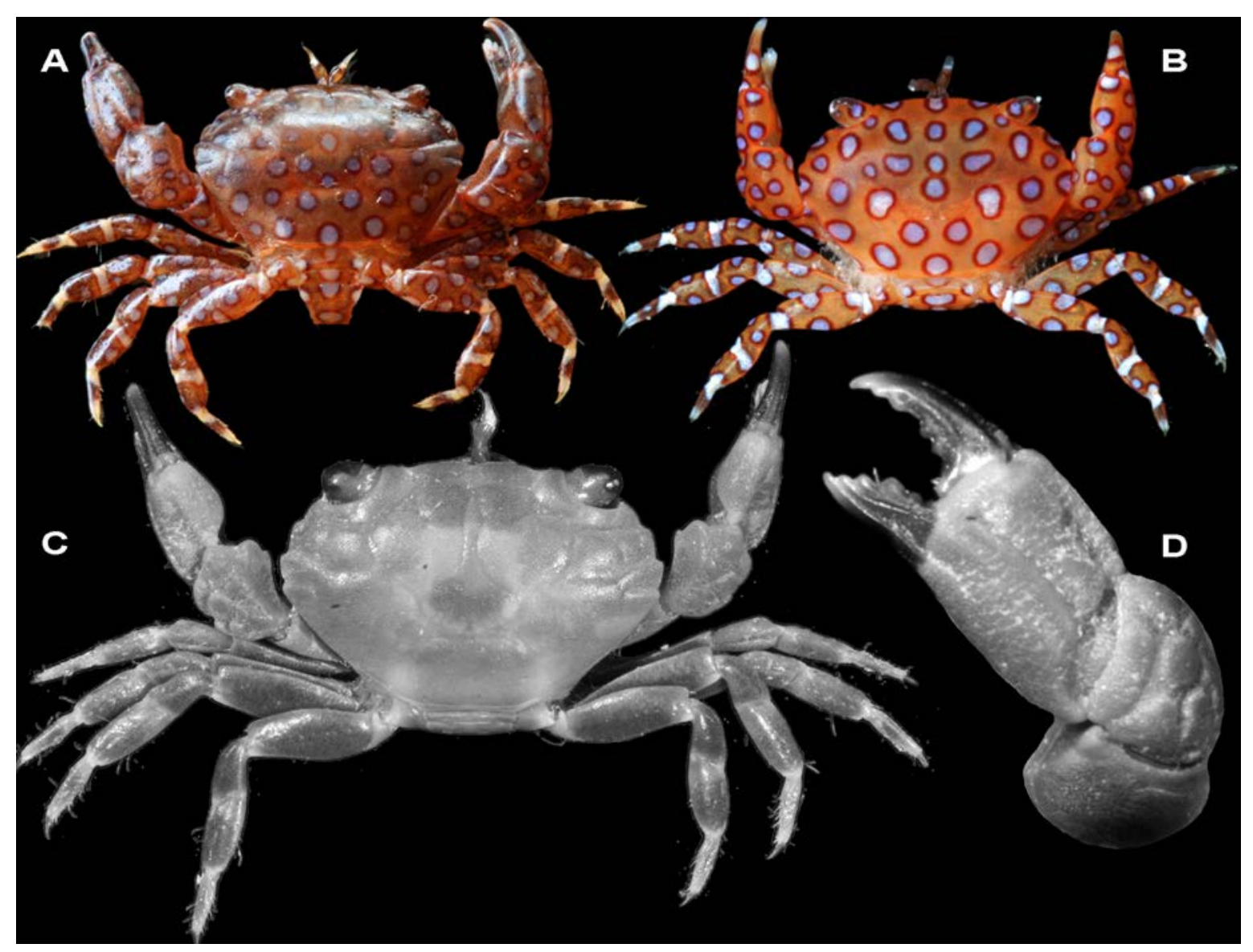

Figure 18. Xanthias maculatus s.l. Mayotte specimens have intermediate characters between $X$. maculatus and X. joanneae - Color pattern: A) 1 त 5.0×7.5 mm, MNHN-IU-2009-2633 (coloration slightly altered by preservative); B) $1+3.7 \times 6.5 \mathrm{~mm}$, MNHN-IU-2009-2633. Details of carapace, legs and outer face of chela: C) 1 + $5.9 \times 8.7 \mathrm{~mm}$, MNHN-IU-2009-2634; D) same, outer face of left chela.

\section{Zozymodes cavipes (Dana, 1852) (Figure 19C)}

MATERIAL EXAMINED - Mayotte KUW 2009, st. 6, 'Déversoir Badamiers', intertidal, Petite Terre, $1 \widehat{\jmath}$ $11.5 \times 16.9 \mathrm{~mm}, 1$ q $9.5 \times 14.1 \mathrm{~mm}, \mathrm{MNHN}-\mathrm{IU}-2009-2592$; st. 10, Islet 'Quatre frères, Vatou', intertidal, 1 + $7.5 \times 11 \mathrm{~mm}$, MNHN B32438, MNHN-IU-2009-1200; st. 26, Mutsumbatsou reef flat, intertidal at low tide, 1 ㅇ $10.2 \times 15.5 \mathrm{~mm}, 1$, MNHN B32439, MNHN-IU-2009-1201, $1 \mathrm{O}^{2}, 2$ 우, coll. J. -M. Bouchard, MNHN B32440, MNHN-IU-2009-1202; st. 26c, Mutsumbatsou reef flat, coll. J. -M Bouchard 03/08/2008, intertidal 2ổ $11.3 \times 16.1 \mathrm{~mm}, 13.2 \times 20.7 \mathrm{~mm}, 1$ + $12.2 \times 18.8 \mathrm{~mm}, 1$ juv., MNHN-IU-2009-2594; st. 29, intertidal, beach, Mboianatsa, Ngouja Hotel, 1 đิ $13.2 \times 20.4$ mm, MMNHN-IU-2009-2593; st. 38, southwest Bay Chiconi/Sada, intertidal, coll. J. -M. Bouchard, 24 July 2008, 1 sp. $10.4 \times 16.2 \mathrm{~mm}$, plus $2 \mathrm{spp}$., not located in MNHN.

OTHER RECORDS - Zozymodes cavipes - Guinot, 1967b: 269, list with Mayotte. - Serène, 1984: 152, Glorieuses, intertidal, coll. A. Crosnier, September 1958, 1ð 11.8×17.1 mm, MNHN. - Poupin et al., 2013c: 12, Glorieuses.

GEOGRAPHIC AND DEPTH RANGES — IWP, Red Sea, Mozambique to Japan, western Australia; intertidal, shallow subtidal. 


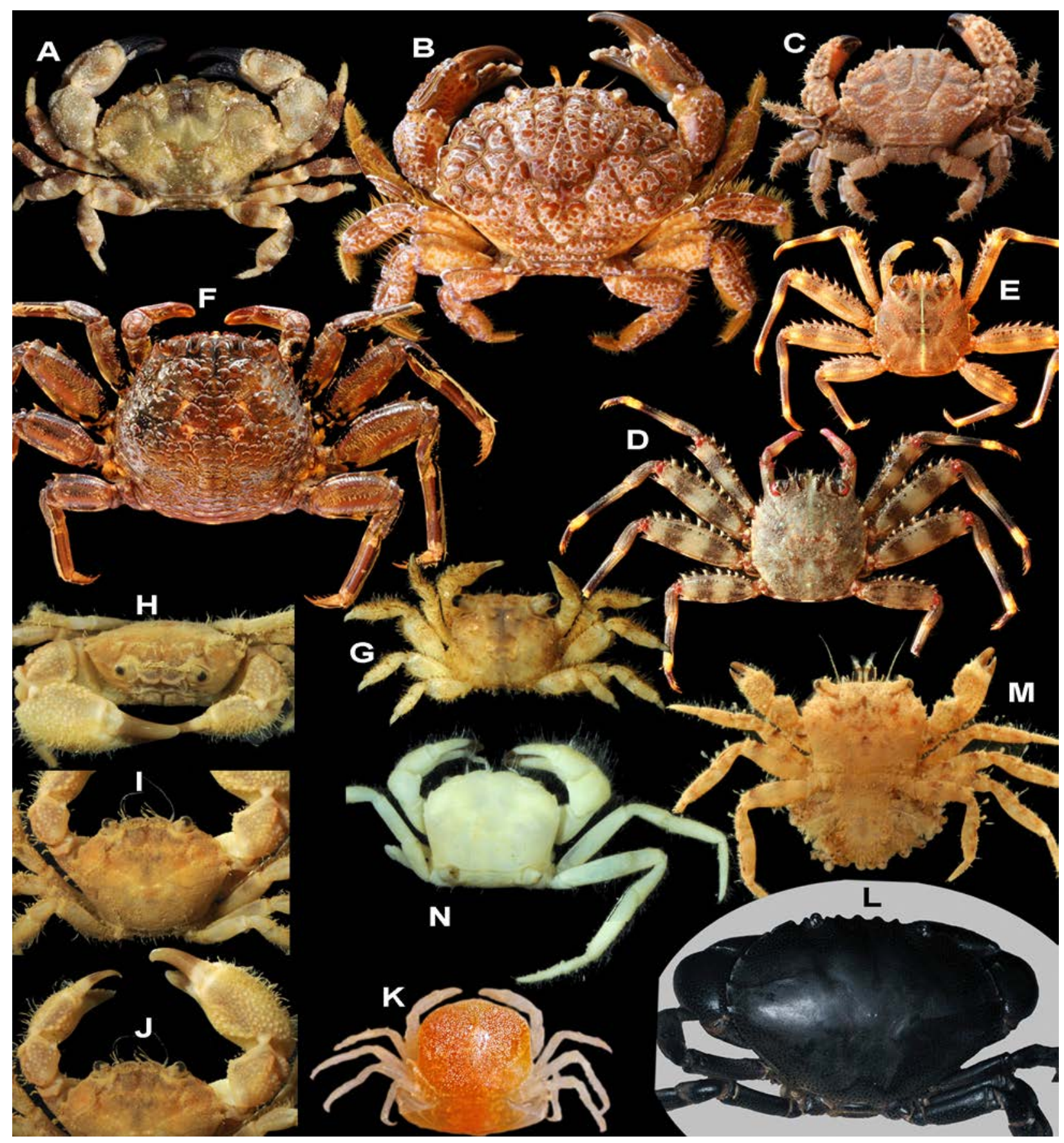

Figure 19. Crabs from Mayotte KUW 2009. Xanthidae - A) Xanthias lamarckii, $1 \lesssim 12.7 \times 19.4 \mathrm{~mm}$,

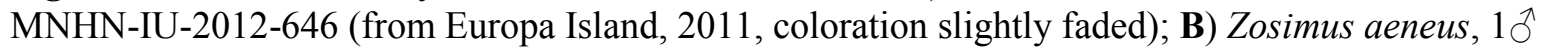
$41 \times 61 \mathrm{~mm}$, MNHN-IU-2009-1165; C) Zozymodes cavipes, 1 + $7.5 \times 11.0 \mathrm{~mm}$, MNHN B32438 -

Grapsoidea - D) Percnon guinotae, 1 q ov. $25.5 \times 22.4 \mathrm{~mm}$, MNHN-IU-2009-973; E) P. planissimum, 1 q ov. 17.5×15.5 mm, MNHN-IU-2009-976; F) Plagusia squamosa, 1 + 37.0×38.0 mm MNHN-IU-2009971; G) Nanosesarma jousseaumei, $1 \overbrace{}^{\Uparrow} 3.1 \times 3.6$ mm, MNHN-IU-2009-2664 (preserved) - Pilumnidae H-J) Latopilumnus malardi, $1 \lesssim 5.3 \times 7.2 \mathrm{~mm}$, MNHN-IU-2013-7236 (preserved) - Pinnotheridae - K) ?Nepinnotheres pectinicola, 1 + 3.8 $\times 4.4 \mathrm{~mm}$, MNHN-IU-2013-7238 - Oziidae - L) Ozius guttatus, not in collection, CW about $60 \mathrm{~mm}$ (photo N. Verneau) - Undetermined - M) ?Pilumnus sp. A, 1 \% ov. $4.0 \times 5.5$ mm, MNHN-IU-2013-7233 (preserved); N) ?Pilumnus sp. C, 1 ㅇ 4.2×5.4 mm, MNHN-IU-2013-7235 (preserved). 


\title{
Superfamily Grapsoidea MacLeay, 1838
}

\author{
Family Gecarcinidae MacLeay, 1838
}

\section{Cardisoma carnifex (Herbst, 1796)}

MATERIAL EXAMINED - See Bouchard et al., 2013: 17, fig. 12 - Mayotte KUW 2009, st. 6, 'Déversoir Badamiers', Petite Terre, 1 + 53×64 mm, MNHN B32410, MNHN-IU-2009-1172, 1 § 65×75.5 mm, MNHN B32411, MNHN-IU-2009-1173; st. 29, photographs, no specimen collected.

OTHER RECORDS - Cardisoma carnifex - Guinot, 1967b: 289, list with Comoros (Grande Comore), Mayotte. - Bouchard, 2009: 6, 8, Mayotte, 1ठ 61×74 mm, MNHN B32409, MNHN-IU-2009-1171. Poupin et al., 2013c: 12, Glorieuses, Island du Lys.

GEOGRAPHIC AND DEPTH RANGES - IWP, Red Sea, South Africa to Japan, Guam, Line Islands, French Polynesia; supratidal, land.

\section{Family Grapsidae MacLeay, 1838}

\section{Geograpsus crinipes (Dana, 1851)}

MATERIAL EXAMINED - See Bouchard et al., 2013: 25, fig. 20A - Mayotte KUW 2009, st. 21a, east Islet Choizil, Malandzamiayatsini, supratidal, $1 \overbrace{}^{\Uparrow} 36.0 \times 42.5$ mm, MNHN B32042, MNHN-IU-2009-961.

OTHER RECORDS - Poupin et al., 2013c: 12, Glorieuses, Island du Lys.

GEOGRAPHIC AND DEPTH RANGES - IWP, Red Sea, Somalia, ?Tanzania, Mayotte (this fieldwork) to Hawaii, French Polynesia, Easter Island; supratidal, land.

\section{Geograpsus grayi (H. Milne Edwards, 1853)}

MATERIAL EXAMINED - See Bouchard et al., 2013: 25, fig. 20B - Mayotte KUW 2009, st. 1, beach, supratidal, Trévani 1 đ̊ $38.5 \times 48.0$ mm, MNHN B32041, MNHN-IU-2009-960.

OTHER RECORDS - Poupin et al., 2013c: 12, Glorieuses.

GEOGRAPHIC AND DEPTH RANGES - IWP, Red Sea, Tanzania, Mayotte (this fieldwork), Madagascar to Japan, French Polynesia, Henderson Island; supratidal, land.

\section{Grapsus fourmanoiri Crosnier, 1965}

MATERIAL EXAMINED - See Bouchard et al., 2013: 25, fig. 20C-D - Mayotte KUW 2009, st. 1, beach, Trévani, 1 + $25.0 \times 28.0 \mathrm{~mm}$, MNHN B32046, MNHN-IU-2009-965; st. 2, intertidal between Trévani to Kangani Mangrove, 3 $\widehat{\partial} 17.4 \times 20.4$ to $27.2 \times 31.0 \mathrm{~mm}$, MNHN B32045, MNHN-IU-2009-964; st. 6, 'Déversoir Badamiers', Petite Terre, 1 juv. $16.3 \times 19.0$ mm, MNHN B32063, MNHN-IU-2009-982; st. 10, east Islet 'Quatre frères, Vatou', $2 \widehat{\jmath}$ đ’ $15.0 \times 17.0 \mathrm{~mm}, 18.0 \times 20.7 \mathrm{~mm}, 2$ 우 우 $15.8 \times 18.6 \mathrm{~mm}$, $25.6 \times 30.0 \mathrm{~mm}$ (ov.), MNHN B32044, MNHN-IU-2009-963; st. 15, northeast beach Islet M'tzamboro, 1 đ̊ 13.4×15.5 mm, 1 juv. 7.5×9.0 mm, MNHN B32060, MNHN-IU-2009-979; st. 21a, east Islet Choizil, Malandzamiayatsini, 4 ๙ึ $8.2 \times 9.5$ to $24.5 \times 28.0 \mathrm{~mm}, 4$ 우 $13.5 \times 16.0$ to $21.0 \times 24.3 \mathrm{~mm}$ (ov.), MNHN B32043, MNHN-IU-2009-962; st. 26, Mutsumbatsou reef flat, $1 \overbrace{}^{\Uparrow} 17.3 \times 19.7 \mathrm{~mm}, 3$ 우 $11.5 \times 13.0$ to $13.0 \times 15.3 \mathrm{~mm}$, MNHN B32061, MNHN-IU-2009-980; st. 29, beach, Mboianatsa, Ngouja Hotel, 1 juv. 7.0×8.6 mm, MNHN B32062, MNHN-IU-2009-981; Coll. J. -M. Bouchard, mangrove, Malamani, 1 đ̄ 32.7×36.0 mm, MNHN B32047, MNHN-IU-2009-966.

OTHER RECORDS - Grapsus fourmanoiri - Crosnier, 1965: 12, Mayotte. - Poupin et al., 2013c: 12, 1 sp. MNHN-IU-2013-7319, 2 spp. MHNH-IU-2013-7322.

GEOGRAPHIC AND DEPTH RANGES - WIO, Somalia, South Africa to Seychelles, Madagascar, Réunion; supratidal, land. 


\section{Grapsus tenuicrustatus (Herbst, 1783)}

MATERIAL EXAMINED - See Bouchard et al., 2013: 25, fig. 20E-F - Mayotte KUW 2009, st. 21, rocky shore, east Islet Choizil, Malandzamiayatsini, 3 우 $18.2 \times 20.2$ to $39.5 \times 41.3 \mathrm{~mm}$, MNHN B32049, MNHN-IU-2009-968; st. 26, Mutsumbatsou reef flat, $1 \sigma^{\uparrow} 43.0 \times 45.5$ mm, MNHN B32050, MNHN-

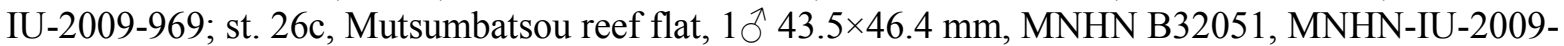
970; st. 38, southwest Bay Chiconi/Sada, coll. J. -M. Bouchard, intertidal, 24 July 2008, 2 q 9 $22.0 \times 24.2 \mathrm{~mm}, 26.0 \times 27.6 \mathrm{~mm}$ (ov.), MNHN B32048, MNHN-IU-2009-967.

OTHER RECORDS - Poupin et al., 2013c: 12, Glorieuses.

GEOGRAPHIC AND DEPTH RANGES - IWP, Red Sea, Mayotte (this fieldwork), South Africa to Hawaii, French Polynesia; intertidal, supratidal.

\section{Metopograpsus messor (Forskål, 1775)}

MATERIAL EXAMINED - See Bouchard et al., 2013: 27 - Mayotte KUW 2009, st. 2, 1ð 9.5×13.2 mm, 2 우 7.6×10.3 mm, 9.0×12.4 mm, det. R. Cleva, MNHN B32067, MNHN-IU-2009-986.

REMARKS - This species can be confused with Metopograpsus thukuhar. See comments in Bouchard et al. (2013: 27).

GEOGRAPHIC AND DEPTH RANGES - IWP, Red Sea, Mayotte (this fieldwork), South Africa to ?Hawaii, ?French Polynesia; intertidal, supratidal. Presence in Hawaii and French Polynesia should be confirmed because of possible confusion with M. thukuhar (see Castro, 2011: 115; Poupin, 2005: 39).

\section{Metopograpsus thukuhar (Owen, 1839)}

MATERIAL EXAMINED - See Bouchard et al., 2013: 27, fig. 21 - Mayotte KUW 2009, st. 2, $1{ }^{\text {^ }}$ $14.0 \times 17.8 \mathrm{~mm}$, MNHN B32066, MNHN-IU-2009-985, $196.5 \times 9.0$ mm, MNHN B32083, MNHN-IU-

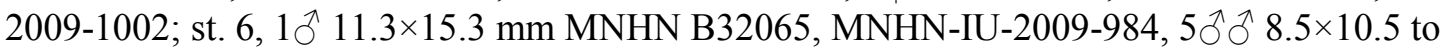
$12.8 \times 17.0 \mathrm{~mm}, 5$ 우 $8.3 \times 11.4$ to $10.8 \times 14.6 \mathrm{~mm}$, det. R. Cleva, MNHN B32064, MNHN-IU-2009983.

GEOGRAPHIC AND DEPTH RANGES - IWP, Red Sea, Mayotte (this fieldwork), South Africa to Hawaii, French Polynesia; intertidal, supratidal.

\section{Pachygrapsus minutus A. Milne-Edwards, 1873}

MATERIAL EXAMINED - See Bouchard et al., 2013: 28, fig. 22A-B - Mayotte KUW 2009, st. 6,

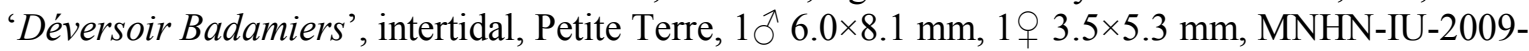
2665, 1 + (with Sacculina) 4.8×6.9 mm, MNHN-IU-2014-9019; st. 10, Islet 'Quatre frères, Vatou', 4 우우 $4.5 \times 6.5$ to $5.7 \times 8.3$ (ov.) $\mathrm{mm}$, MNHN B32068, MNHN-IU-2009-987; st. 26, Mutsumbatsou reef flat, $1 \circlearrowleft 4.3 \times 6.5 \mathrm{~mm}, 1$ ㅇ $3.8 \times 5.6 \mathrm{~mm}$, plus $1 \overbrace{}^{\Uparrow} 3.3 \times 5.2 \mathrm{~mm}$, MNHN B32069, MNHN-IU-2009-988; st. 31, Bandrélé, 'Plage musicale', $10^{\Uparrow} 5.3 \times 7.6 \mathrm{~mm}, 5$ 우 $3.0 \times 4.5$ to $4.8 \times 7.0 \mathrm{~mm}$, MNHN B32070, MNHN-IU-2009-989.

OTHER RECORDS - Poupin et al., 2013c: 12, Glorieuses, 7 spp. MNHN-IU-2013-7323.

GEOGRAPHIC AND DEPTH RANGES - IP, Red Sea, Mayotte (this fieldwork), South Africa to Hawaii, French Polynesia, Clipperton, Revillagigedo Islands; intertidal.

\section{Pachygrapsus planifrons De Man, 1888}

MATERIAL EXAMINED - See Bouchard et al., 2013: 28, fig. 22C-D - Mayotte KUW 2009, st. 2, intertidal between Trévani beach and Kangani Mangrove, 1 q ov. $4.7 \times 5.6$ mm, MNHN B-32365, MNHN-IU2009-1138.

OTHER RECORDS - Poupin et al., 2013c: 12, Glorieuses, 1 sp. MNHN-IU-2013-7324.

GEOGRAPHIC AND DEPTH RANGES - IWP, Tanzania, Mayotte (this fieldwork), Seychelles to Hawaii, French Polynesia, Clipperton; intertidal. 


\section{Family Percnidae Števčić, 2005}

Percnon guinotae Crosnier, 1965 (Figure 19D)

MATERIAL EXAMINED - Mayotte KUW 2009, st. 9b, S-shaped Pass, coll. J. -M. Bouchard, 1 q ov. $32.5 \times 28.5 \mathrm{~mm}, \mathrm{MNHN}$ B32055, MNHN-IU-2009-974; st. 11,2 , $q$ ov. $31.6 \times 28.5 \mathrm{~mm}, 43.0 \times 37.6$ mm, MNHN B32053, MNHN-IU-2009-972; st. 35,1 q ov. $25.5 \times 22.4$ mm, MNHN B32054, MNHNIU-2009-973.

OTHER RECORDS - Percnon guinotae - Crosnier, 1965: 83, Glorieuses. - Guinot, 1967b: 289, list with Glorieuses.

REMARKS - In live Percnon guinotae the cornea is bright red (vs. black cornea P. planissimum; for color photographs of both species see Legall and Poupin, 2018).

GEOGRAPHIC AND DEPTH RANGES - IWP, Somalia, Tanzania, Mayotte (present study), Madagascar to Wallis and Futuna, French Polynesia; low intertidal, shallow subtidal.

Percnon planissimum (Herbst, 1804) (Figure 19E)

MATERIAL EXAMINED - Mayotte KUW 2009, st. 26, 19 ov. $17.5 \times 15.5$ mm, MNHN B32057, MNHNIU-2009-976; st. 31, 1 đ̊ 9.0×8.0 mm, 1 q ov. 13.0×12.0 mm, MNHN B32056, MNHN-IU-2009-975.

OTHER RECORDS - Percnon planissimum - Crosnier, 1965: 90, Mayotte, Glorieuses. - Guinot, 1967b: 289, list with Mayotte, Glorieuses. - Poupin et al., 2013c: 12, Glorieuses.

GEOGRAPHIC AND DEPTH RANGES - IWP, Red Sea, South Africa to Hawaii, French Polynesia; low intertidal, shallow subtidal

\section{Family Plagusiidae Dana, 1851}

Plagusia squamosa (Herbst, 1790) (Figure 19F)

MATERIAL EXAMINED - Mayotte KUW 2009, st. 11, 1 đ 34.0×35.0 mm, 1 + 37.0×38.0 mm MNHN B32052, MNHN-IU-2009-971.

OTHER RECORDS - Plagusia depressa tuberculata - Crosnier, 1965: 80, Mayotte (Bandéli). - Guinot, 1967: 288, list with Comoros / Plagusia depressa tuberculata Lamarck, 1818 accepted as P. squamosa in WoRMS (2018).

REMARKS - Plagusia squamosa is similar to Plagusia immaculata Lamarck, 1818. Vannini and Valmori (1981: 92) illustrate both species, carapace having strong hairy tubercles in P. squamosa instead of low glabrous tubercles in P. immaculata.

GEOGRAPHIC AND DEPTH RANGES - IP, Red Sea, South Africa to Hawaii, French Polynesia, Clipperton and eastern Pacific (Gulf of California to Acapulco); invasive in the Mediterranean Sea ( $c f$. Zaouali et al., 2007); low intertidal, shallow subtidal, and on flotsam and ship's hulls.

\section{Family Sesarmidae Dana, 1851}

\section{Metasesarma obesum (Dana, 1851)}

MATERIAL EXAMINED - See Bouchard et al., 2013: 19, fig. 14 - Mayotte KUW 2009, st. 21 a, upper littoral, Islet Choizil, $2 \widehat{\jmath} \widehat{\widehat{\sigma}} 6.5 \times 7.5 \mathrm{~mm}, 11.8 \times 13.0 \mathrm{~mm}, 3$ 우 $7.4 \times 8.5$ to $11.5 \times 12.5 \mathrm{~mm}, \mathrm{MNHN}$ B32082, MNHN-IU-2009-1001.

REMARKS - Metasesarma obesum is often reported as M. rousseauxi $\mathrm{H}$. Milne Edwards, 1853, the later now accepted as a junior synonym (WoRMS, 2018).

GEOGRAPHIC AND DEPTH RANGES - IWP, Tanzania (Zanzibar), Mayotte (this fieldwork), Madagascar to Taiwan, Philippines, Guam, French Polynesia; supratidal, land. 
Nanosesarma jousseaumei (Nobili, 1905) (Figure 19G)

MATERIAL EXAMINED - Mayotte KUW 2009, st. 10, intertidal, east Islet 'Quatre frères, Vatou', $1{ }^{\wedge}$ $3.1 \times 3.6 \mathrm{~mm}, 1$ ㅇ $3.75 \times 4.5 \mathrm{~mm}$, det. N. Naderloo, MNHN-IU-2009-2664.

REMARKS - These specimens are not included in the Sesarmidae presented by Bouchard et al. (2013). They were retrieved in a jar containing several undetermined small crabs. By using Crosnier (1965) key and diagnose, without comparative specimens, they were first identified as Nanosesarma ?minutum (De Man, 1887) and registered as such in MNHN. Crosnier (1965) has attributed his own specimens from Madagascar to 'Nanosesarma cf. minutum (De Man)' because of several differences with this De Man species. Holthuis (1977) has suggested that Crosnier's specimens from Madagascar might be Nanosesarma jousseaumei Nobili (1906), described from the Red Sea. Vannini and Valmori (1981) have attributed a few specimens from Somalia to $N$. minutum but with indication that $N$. jousseaumei could be also retained, their specimens 'being in agreement with both descriptions'. More recently Naderloo (2011) has corrected the records of $N$. (?)minutum by Crosnier (1985) and Vannini and Valmori (1981) with assignment to $N$. jousseaumei. Naderloo (pers. comm. 23/02/2012), after examining the close up macrophotographs of Mayotte KUW specimens in Legall and Poupin (2018) has indicated that they 'are highly similar to my specimens from the Persian Gulf' and suggested that they must belong to $N$. jousseaumei, common in WIO.

GeOgRAPHIC AND DEPTH RANGeS - WIO, Gulf of Aden, Djibouti, Persian Gulf, Tanzania to Mayotte (present study), Madagascar; intertidal, supratidal.

\section{Neosarmatium meinerti (De Man, 1887)}

MATERIAL EXAMINED - See Bouchard et al., 2013: 19, fig. 15 - Mayotte KUW 2009, st. 6, 'Déversoir

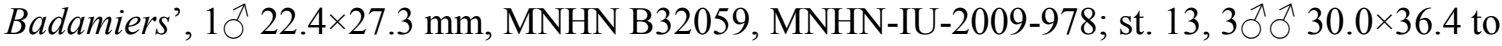
31.5×38.0 mm, MNHN B32038, MNHN-IU-2009-957.

OTHER RECORDS - Sesarma (Sesarma) meinerti - Guinot, 1967: 288, list with Mayotte. - Neosarmatium meinerti - Bouchard, 2009: 6, 13, Mayotte, Malamani mangrove, 3 ○े $30.0 \times 35.8$ to $33.0 \times 39.0 \mathrm{~mm}$, 3 우우 $29.5 \times 35.5$ to $30.4 \times 37.0 \mathrm{~mm}$, MNHN B32035, MNHN-IU-2009-954; 3 $\widehat{\delta} 32.3 \times 34.0$ to $38.0 \times 39.8 \mathrm{~mm}, 1$ ㅇ $29.0 \times 35.8 \mathrm{~mm}, \mathrm{MNHN}$ B32036, MNHN-IU-2009-955; 1 §̊ 33.0×39.4 mm, 1 ㅇ 29.0×35.0 mm, MNHN B32037, MNHN-IU-2009-956.

REMARKS - Neosarmatium meinerti is a species complex studied by Ragionieri et al. $(2009,2010$, 2012). The specimens from Mayotte could be assigned to N. africanum Ragionieri, Fratini and Schubart, 2012. Bouchard et al. (2013: 20) however, failed to separate confidently the two species (More comments are in Bouchard et al. 2013).

GEOGRAPHIC AND DEPTH RANGES (for N. meinerti cf. Ragionieri et al. 2012) - WIO, ?Mayotte, Seychelles (Aldabra, Mahé) to Mauritius, Rodrigues; supratidal, land.

\section{Neosarmatium smithi (H. Milne Edwards, 1853)}

MATERIAL EXAMINED - See Bouchard et al., 2013: 21, fig. 16 - Mayotte KUW 2009, st. 13, mangrove, Malamani, 1 ठ 37.0×39.7 mm, MNHN B32040, MNHN-IU-2009-959.

OTHER RECORDS - Neosarmatium smithi - Bouchard, 2009: 6, 11, Mayotte, Malamani mangrove, $10 \hat{~}$ $37.2 \times 39.4 \mathrm{~mm}, 2$ 우 $15.4 \times 17.5 \mathrm{~mm}, 16.8 \times 18.6 \mathrm{~mm}$, MNHN B32039, MNHN-IU-2009-958.

REMARKS - Bouchard et al. (2013: 21) can be consulted for differences between Neosarmatium smithi and $N$. meinerti, collected at same stations.

GEOGRAPHIC AND DEPTH RANGES - IWP, Red Sea, Mayotte (this fieldwork), South Africa to Japan, New Caledonia, Fiji; supratidal, land. 


\section{Parasesarma leptosoma (Hilgendorf, 1869) s.l.}

MATERIAL EXAMINED - See Bouchard et al., 2013: 21, fig. 16 - Mayotte KUW 2009, coll. J. -M.

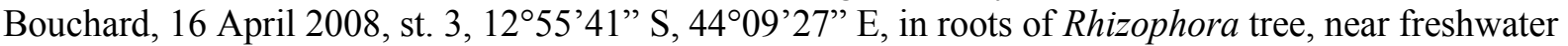
rill, 1 đ 12.0×13.6 mm, MNHN B32081, MNHN-IU-2009-1000.

REMARKS - See Bouchard et al. (2013: 22) for comments on this crab adapted to live in canopy of mangrove trees. According to Rahayu and Ng (2009) Parasesarma leptosoma s.l. is a complex of species in need of revision.

GeOGRAPHIC AND DEPTH RANGeS (P. leptosoma s.1.) - IWP, Kenya, Mayotte (this fieldwork), South Africa to Papua New Guinea, New Caledonia, Fiji; supratidal, land.

\section{Perisesarma guttatum (A. Milne-Edwards, 1869)}

MATERIAL EXAMINED - See Bouchard et al., 2013: 23, fig. 18 - Mayotte KUW 2009, st. 13, mangrove, Malamani 2 juv. (mixed with Macrophthalmus spp.), MNHN B-32364, MNHN-IU-2009-1137.

OTHER RECORDS - Sesarma (Chiromantes) guttata - Guinot, 1967: 288, list with Mayotte. Perisesarma guttatum - Bouchard, 2009: 6, 9, Mayotte, coll. J. -M. Bouchard, in roots of mangrove tree Rhizophora, Malamani, $2 \hat{\jmath} \widehat{o} 15.0 \times 18.3 \mathrm{~mm}, 16.5 \times 20.5 \mathrm{~mm}, 3$ 우 $9.5 \times 12.3$ to $16.2 \times 20.2 \mathrm{~mm}, 1$

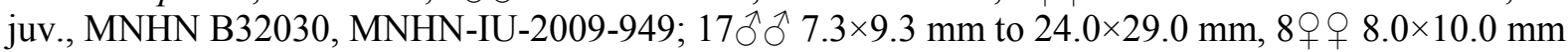
to $16.5 \times 20.8 \mathrm{~mm}, 1$ juv., MNHN B32031, MNHN-IU-2009-950; 4 §ิ $\widehat{\partial} 8.2 \times 10.2 \mathrm{~mm}$ to $22.8 \times 27.8$

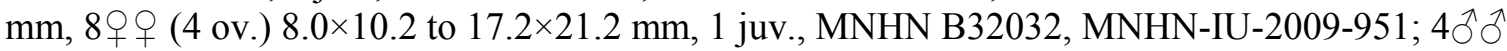
$17.0 \times 21.3$ to $20.6 \times 25.3 \mathrm{~mm}$ (photo ${ }^{-1} 19.0 \times 23.3 \mathrm{~mm}$ ), 1 ㅇ $16.5 \times 21.5 \mathrm{~mm}$, MNHN B32033, MNHNIU-2009-952; st. 2, coll. J. -M. Bouchard, 16/04/2008 in burrow between Rhizophora roots, $12^{\circ} 55.368$ $\mathrm{S}, 45^{\circ} 09.267 \mathrm{E} .1$ q broken, $10 \times 14 \mathrm{~mm}$ (in a jar with $10^{\wedge}$ of Sesarma ortmanni), MNHN B32263, MNHN-IU-2009-1081.

GEOGRAPHIC AND DEPTH RANGES ( $c f$. Naderloo, 2011) - WIO, Red Sea, Gulf of Oman, Mayotte (this fieldwork), South Africa to Madagascar; supratidal, land.

\section{Sesarma ortmanni (Crosnier, 1965)}

MATERIAL EXAMINED - See Bouchard et al., 2013: 18, fig. 13 as 'Chiromantes' ortmanni - Mayotte KUW 2009, st. 2, coll. J. -M. Bouchard, 16/04/2008, $12^{\circ} 55.368 \mathrm{~S}, 45^{\circ} 09.267 \mathrm{E}$, mangrove, burrows in Rhizophora tree roots, $1{ }^{\lambda} 11.5 \times 15.0 \mathrm{~mm}$ (collected with Neosarmatium meinerti and 1 ㅇ Perisesarma guttatum), MNHN B32262, MNHN-IU-2009-1080.

REMARKS - Bouchard et al. (2013: 18) have additional comments about the taxonomy of this species.

GEOGRAPHIC AND DEPTH RANGES - WIO, Somalia, Tanzania, Mozambique, Mayotte (this fieldwork) to Madagascar; supratidal, land.

\section{Sesarmops impressus (H. Milne Edwards, 1837)}

MATERIAL EXAMINED - See Bouchard et al., 2013: 24, fig. 19 - Mayotte KUW 2009, st. 13, mangrove, Malamani, 3 $\lesssim$ ô $14.5 \times 16.8$ to $36.0 \times 42.0 \mathrm{~mm}$, MNHN B32034, MNHN-IU-2009-953.

OTHER RECORDS - Sesarma nodulifera de Man - Lenz, 1910: 562, Comoros (Mohéli), 2 spp. larger $16 \times 17 \mathrm{~mm} /$ Not Geosesarma noduliferum (De Man, 1892) following re-examination of Lenz's specimens by Crosnier (1965: 63). - Sesarma (Sesarma) impressa - Crosnier, 1965: 63, Comoros (Mohéli). - Guinot, 1967: 287, list with Comoros. - Sesarmops impressum - Keith et al., 2006: 36, Comoros (Mohéli), Mayotte. - Sesarmops impressus - Coll. Anker and Michonneau, 2008, Mayotte, st. MAY08-St3, Hajangoua, in bushes and under rocks near ruins of sugar factory, UFID 13657, 13667. Bouchard, 2009: 6, 15, Mayotte, cultivated land in upper Malamani mangrove, $3 \widehat{\partial} \widehat{\partial} 14.5 \times 16.8$ to 36.0×42.0 mm, MNHN B32034, MNHN-IU-2009-953.

GEOGRAPHIC AND DEPTH RANGES - IWP, Tanzania, Seychelles, Comoros, Mayotte, Madagascar to Taiwan, Papua New Guinea, Samoa; supratidal, land. 


\section{Family Varunidae H. Milne Edwards, 1853}

\section{Pseudograpsus albus Stimpson, 1858}

MATERIAL EXAMINED - See Bouchard et al., 2013: 29, fig. 27A - Mayotte KUW 2009, st. 15, intertidal under stones, beach, northeast Islet M'tzamboro, 1 + 5.3×5.9 mm, MNHN B32084, MNHN-IU-20091003.

GEOGRAPHIC AND DEPTH RANGES — IWP, Mayotte (this fieldwork), Madagascar, Réunion to Japan, Line Islands, French Polynesia; supratidal.

\section{Pseudohelice subquadrata (Dana, 1851)}

MATERIAL EXAMINED - See Bouchard et al., 2013: 29, fig. 24; Bouchard, 2009: 6, 28 - Mayotte KUW 2009, st. 13, Malamani mangrove, coll. J. -M. Bouchard, 12/12/2008, $12^{\circ} 55^{\prime} 07^{\prime}$ ' S, 45 $09^{\circ} 07^{\prime}$ ' E, 2 ઈิ $11.3 \times 13 \mathrm{~mm}, 11.7 \times 13.8 \mathrm{~mm}, 1$ ㅇ $11.0 \times 13.5 \mathrm{~mm}, \mathrm{MNHN}$ B-32363, MNHN-IU-2009-1136.

REMARKS - Formerly reported in WIO as Helice leachii Hess, 1865, a junior synonym (WoRMS, 2018).

GEOGRAPHIC AND DEPTH RANGES - IWP, Red Sea, Mayotte (this fieldwork), Tanzania, South Africa to Japan, French Polynesia; supratidal, land.

\section{Thalassograpsus harpax (Hilgendorf, 1892)}

MATERIAL EXAMINED - See Bouchard et al., 2013: 32, fig. 26 - Mayotte KUW 2009, st. 2, intertidal from Trévani to Kangani Mangrove, $1 \delta^{\Uparrow} 6.1 \times 7.1 \mathrm{~mm}, 1$ ov. $6.4 \times 7.5 \mathrm{~mm}$, MNHN B32261, MNHNIU-2009-1079; st. 6, 'Déversoir Badamiers', Petite Terre, intertidal, 1 + 5.2×6.0 mm, MNHN-IU2009-2666; st. 31, Bandrélé 'Plage musicale', 5 q ov. $5.0 \times 5.4$ to $6.6 \times 7.6 \mathrm{~mm}, 1$ + $6.0 \times 6.9 \mathrm{~mm}$, MNHN B32260, MNHN-IU-2009-1078.

GEOGRAPHIC AND DEPTH RANGES - IWP, Red Sea, Gulf of Aden, Persian Gulf, Mayotte (this fieldwork), Tanzania to Japan, French Polynesia; supratidal.

\section{Varuna litterata (Fabricius, 1798)}

MATERIAL EXAMINED - See Bouchard et al., 2013: 32, fig. 27B-D - Mayotte KUW 2009, st. 10, Islet 'Quatre frères, Vatou', 1ठ 36.3×41.0 mm, MNHN B32058, MNHN-IU-2009-977.

OTHER RECORDS - Varuna litterata - Lenz, 1910: 560, Comoros (Mohéli). - Crosnier, 1965: 34, Comoros (Grande Comore, Mohéli). - Keith et al., 2006: 36, Comoros (Anjouan, Mohéli), Mayotte.

GEOGRAPHIC AND DEPTH RANGES - IWP, Somalia, South Africa to Japan, French Polynesia; rivers, brackish waters or at sea (drifting).

\section{Superfamily Ocypodoidea Rafinesque, 1815}

\section{Family Dotillidae Stimpson, 1858}

\section{Dotilla fenestrata Hilgendorf, 1869}

MATERIAL EXAMINED - See Bouchard et al., 2013: 34, fig. 28 - Mayotte KUW 2009, st. 1, beach, intertidal, Trévani, 1ठ 4.0×5.4 mm, MNHN B32078, MNHN-IU-2009-997; st. 29, intertidal, beach, Mboianatsa, Ngouja Hotel, 1 ^ 3.7×5.6 mm, 1 juv., MNHN B32079, MNHN-IU-2009-998; st. 31, Bandrélé, 'Plage musicale', 19 3.2×4.2 mm, MNHN B32080, MNHN-IU-2009-999; beach, Mliha, coll. Lisa, Tom and J. -M. Bouchard, $05 / 01 / 2010,5$ ते $2.2 \times 2.6 \mathrm{~mm}$ to $4.5 \times 5.8 \mathrm{~mm}, 2$ ㅇ $92.7 \times 3.0$ mm, 3.3 $\times 3.6 \mathrm{~mm}$, MNHN B32257, MNHN-IU-2009-1075; same coll., upper beach of Ambato, $3 \mathrm{~km}$

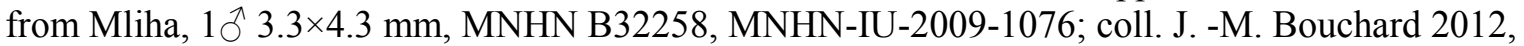
sandy beach, det. J. Poupin January 2013, 12 spp. MNHN-IU-2013-7239. 
OTHER RECORDS - Dotilla fenestrata - Crosnier, 1965: 120, Mayotte. - Guinot, 1967: 282, list with Mayotte.

GEOGRAPHIC AND DEPTH RANGES - WIO. Somalia, Mozambique, South Africa, Madagascar; supratidal.

\section{Family Macrophthalmidae Dana, 1851}

\section{Chaenostoma crassimanus Stimpson, 1858}

MATERIAL EXAMINED - Mayotte KUW 2009, st. 31, low intertidal, Bandrélé 'Plage musicale', $1{ }^{\lambda}$ 3.6×4.6 mm, 1 juv. MNHN B32074, MNHN-IU-2009-993.

\section{OTHER RECORDS}

Macrophthalmus (Chaenostoma) boscii Audouin, 1826 - Poupin and Bouchard, 2010: 62, Mayotte, in part only the 2 spp. examined at st. 31, MNHN B32074, MNHN-IU-2009-993, accepted as Chaenostoma crassimanus in Teng et al. (2016: 17, 26, tab. 1) [in the same contribution $197.5 \times 9.1$ mm at st. 1, MNHN B32073, MNHN-IU-2009-992 is accepted by Teng et al. $(2016: 17,26$, tab. 1) as Chaenostoma sinuspersici (Naderloo and Türkay, 2010)].

Chaenostoma sinuspersici - Bouchard et al., 2013: 36, Mayotte, in part, same 2 spp. at st. 31 than in Poupin and Bouchard (2010), MNHN B32074, MNHN-IU-2009-993 - Not $C$. sinuspersici but $C$. crassimanus cf. Shih et al. (2015: 79) and Teng et al. (2016: 17, 26, tab. 1), see remarks.

Chaenostoma crassimanus - Shih et al., 2015: 79, Mayotte. - Teng et al., 2016: 26, Mayotte - Same specimens than Poupin and Bouchard (2010), Bouchard et al. (2013), 2 spp. MNHN-IU-2009-993.

REMARKS - Just after Mayotte KUW 2009 expedition the specimens collected at st. 1 (MNHN B32073, MNHN-IU-2009-992) and st. 31 (MNHN B32074, MNHN-IU-2009-993) were reported by Poupin and Bouchard (2010: 62) as Macrophthalmus (Chaenostoma) boscii Audouin, 1826 and used as 'Comparison material' to described a new species from Mayotte, Macrophthalmus (Chaenostoma) lisae. The same specimens (st. 1 and st. 31) were later listed as Chaenostoma sinuspersici by Bouchard et al. (2013) following the revision of the 'Macrophthalmus boscii-group' by Naderloo and Türkay (2010) where typical Chaenostoma boscii is restricted to the Red Sea and most other WIO records of ' $C$. boscii' are corrected into $C$. sinuspersici new species. More recently Teng et al. (2016) have recognized two distinct species in this material, Chaenostoma crassimanus for two specimens at st. 31 (MNHN B32074, MNHN-IU-2009-993) and Chaenostoma sinuspersici for one specimen at st. 1 (MNHN B32073, MNHN-IU-2009-992).

GEOGRAPHIC AND DEPTH RANGES - IWP (but not Red Sea), probably East African coast, from Somalia to South Africa (as Macrophthalmus boscii), Mayotte (this fieldwork), Madagascar to Taiwan, Japan (Ryukyus), New Caledonia; intertidal.

\section{Chaenostoma lisae (Poupin and Bouchard, 2010)}

MATERIAL EXAMINED - Mayotte KUW 2009, st. 26, 1 ^ 3.75×4.9 mm (holotype) MNHN B32254, MNHN-IU-2009-1072, $1 \mathcal{O}^{\lambda} 4.1 \times 5.4 \mathrm{~mm}, 3$ 우 ov. $3.1 \times 4.1$ to $3.95 \times 5.3 \mathrm{~mm}, 3$ 우 $2.6 \times 3.3$ to $3.7 \times 4.9$ mm, 1 juv. broken (paratypes) MNHN B32071, MNHN-IU-2009-990, 1 ov. $3.85 \times 5.1 \mathrm{~mm}$, (paratype) MNHN B32362, MNHN-IU-2009-1135; st. 13b, coll. J. -M. Bouchard, Malamani mangrove, 1 ㅇ ov. $3.75 \times 5.01 \mathrm{~mm}$ (paratype) MNHN B32072, MNHN-IU-2009-991.

OTHER RECORDS - Macrophthalmus (Chaenostoma) lisae Poupin and Bouchard, 2010: 62, same spp. than Mayotte KUW 2009 (MNHN-IU-2009-990, 991, 1072, 1135). - Bouchard et al., 2013: 35, same spp. than Mayotte KUW 2009, but not the specimens recognized by Naderloo (com. pers. in Bouchard

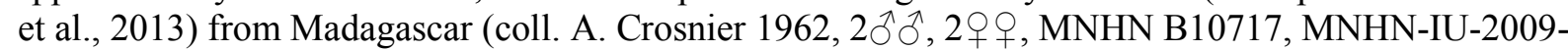
2590) and New Caledonia (fig. 30D, which is st. 9 Pindai, CRISP 2009, MNHN B32603, MNHN-IU2009-2591), that are Chaenostoma crassimanus (see Shih et al., 2015: 79; Teng et al., 2016: 26-27).

Not Chaenostoma lisae - Naderloo, 2013: 2842, Madagascar, coll. A. Crosnier 1962, $2 \hat{\jmath} \hat{\jmath}, 1 q$ ov., MNHN B10717, MNHN-IU-2009-2590; Europa Island (Mozambique Channel), BIORECIE 2011 Expedition [the specimens examined are not listed by Naderloo (2013) but are the same as in Poupin 
et al. (2013b) for Europa Island, 2ðð 3.1×3.8 mm, 3.6×4.6 mm, MNHN-IU-2012-662], st. 4, outer reef, high intertidal, 8 November 2011, coll. J. Poupin; New Caledonia, Pindai, $1 \overbrace{}^{\Uparrow} 4.5 \times 5.69,1$ 우 ov. $5.16 \times 6.79$ 'MNHN' [no number indicated by Naderloo (2013) but must be MNHN B32603, MNHNIU-2009-2591)]. - Poupin et al., 2013b: 13, Europa, 2 ऊ̄ $3.1 \times 3.8 \mathrm{~mm}, 3.6 \times 4.6 \mathrm{~mm}$, MNHN-IU-2012662 [same specimens than in Naderloo (2013)] - At least specimens from Madagascar and New Caledonia are Chaenostoma crassimanus in Shih et al. (2015: 79) and Teng et al. (2016: 26-27). Specimens from Europa Island (st. 4 during BIORECIE 2011 Expedition) were attributed with hesitation to ' $C$. lisae' by J. Poupin because the biotope indicated in field notes (fringing reef, in pools and under stones) was different than for $C$. lisae typical (mudflats). Europa specimens of ' $C$. lisae' were therefore sent to Naderloo (March 2012) to check this identification with molecular sequencing. They are not listed in subsequent studies by Shih et al. (2015) and/or Teng et al. (2016) but R. Naderloo has indicated (mail to J. Poupin. June 2012) that their sequences are similar (99\%) to ' $a$ sequence in GenBank for Macrophthalmus boscii' which indicate that they are probably young of Chaenostoma crassimanus but not $C$. lisae.

REMARKS - Typical Chaenostoma lisae is known only from Mayotte, collected during Mayotte KUW 2009 (st. 13b, 26). It is related to the 'C. boscii/sinuspersici/crassimanus' group that includes three species reported in the IWP as 'Macrophthalmus boscii' before the revisions of Naderloo and Türkay (2010), Shih et al. (2015) and Teng et al. (2016). For its description Chaenostoma lisae was compared by Poupin and Bouchard (2010) with specimens of 'Macrophthalmus boscii' from Mayotte (MNHN B32073, MNHN-IU-2009-992 = Chaenostoma sinuspersici in Teng et al. 2016). Among the characters that are used to recognize C. lisae and ' $C$. boscii/sinuspersici' Poupin and Bouchard (2010) indicate that $C$. lisae is a much smaller species and that it excavates burrows on sandy mudflats (vs. living in rocks and pools of the intertidal, without obvious burrow for ' $C$. boscii/sinuspersici'). Poupin and Bouchard (2010: 65), however, indicate that the two species ( $C$. lisae and ' $C$. boscii/sinuspersici') can be confused, depending on the size of specimens examined: 'the distinction between adult specimens of $M$. lisae and small specimens of $M$. boscii $[=\mathrm{C}$. sinuspersici] of the same size, where indentation between the first and second anterolateral teeth is reduced is more difficult'. Naderloo (2013) has proposed a misleading redescription of ' $C$. lisae' because none of the specimens that he has examined (Madagascar, Europa, New Caledonia) belong to the type series collected during Mayotte KUW 2009. As a result the new diagnosis of $C$. lisae in Naderloo (2013) is erroneous and, following contributions of Shih et al. (2015) and Teng et al. (2016), applies in fact to C. crassimanus. The same error is reproduced in Shih et al. (2015) and Teng et al. (2016). It must be noted that the specimens of ' $C$. lisae' that were sequenced by Teng et al. (2016, tab. 1, Cc7, Cs8) are in fact the 'M. boscii' used as 'Comparison material' by Poupin and Bouchard (2010) when describing $C$. lisae. Logically, and in error, Teng et al. (2016) have concluded that ' $C$. lisae' is a junior synonym of $C$. crassimanus (formerly ' $M$. boscii'). In conclusion, $C$. lisae must still be considered as a valid species with type material limited to specimens identified herein from KUW Mayotte 2009 (most spp. at st. 26; a single sp. at st. 13b). Specimens referred to ' $C$. lisae' in Naderloo (2013), Shih et al. (2015) and Teng et al. (2016) are not this species but C. crassimanus.

GEOGRAPHIC AND DEPTH RANGES - WIO, Mayotte only; upper intertidal.

\section{Chaenostoma sinuspersici (Naderloo and Türkay, 2010)}

MATERIAL EXAMINED - Mayotte KUW 2009, st. 1, beach, Trévani, 1 q 7.5×9.1 mm, MNHN B32073, MNHN-IU-2009-992 [registered in MNHN as Macrophthalmus (Chaenostoma) boscii].

OTHER RECORDS - Macrophthalmus (Chaenostoma) boscii - Poupin and Bouchard, 2010: 62, Mayotte, 'Comparison material', in part only, st. 1, Trévani, 1 + 7.5×9.1 mm, MNHN B32073, MNHN-IU2009-992 / Not Chaenostoma boscii, restricted to Red Sea (cf. Naderloo and Türkay, 2010) but $C$. sinuspersici following Teng et al. (2016: 17, 26, tab. 1) - Chaenostoma sinuspersici - Bouchard et al., 2013: 36, Mayotte, in part only st. 1, Trévani, 1 \% 7.5×9.1 mm, MNHN B32073, MNHN-IU-2009-992 [same than in Poupin and Bouchard (2010)]. - Teng et al., 2016: 26 - Mayotte, same sp., st. 1, Trévani, ' 1 q 9.8 mm', MNHNIU-2009-992'. 
REMARKS - In Bouchard et al. (2013: 36) other specimens listed as 'Chaenostoma sinuspersici' are: $C$. crassimanus (Mayotte KUW 2009, st. 31) and C. orientale (fig. 30C only, photo of $1 \delta^{\lambda} 8.1 \times 14.1 \mathrm{~mm}$ from New Caledonia, Nouméa, Nouville, st. 2, intertidal, MNHN-IU-2013-9291; corrected in Teng et al. (2016: 27; measured as ' $1 \delta^{\Uparrow} 9.1 \mathrm{~mm}$ ').

GEOGRAPHIC AND DEPTH RANGES ( $c f$. Teng et al., 2016) - WIO, Persian Gulf, Somalia, Mozambique, Mayotte (this fieldwork), Madagascar; ?South Africa, intertidal.

\section{Macrophthalmus depressus Rüppel, 1830}

MATERIAL EXAMINED - See Bouchard et al., 2013: 38, fig. 32 - Mayotte KUW 2009, st. 13, 1 久 $7.0 \times 11.4 \mathrm{~mm}$ (photo), 3 우 $7.4 \times 11.9$ to $9.4 \times 15.1 \mathrm{~mm}$, MNHN B32075, MNHN-IU-2009-994; st. 13b,

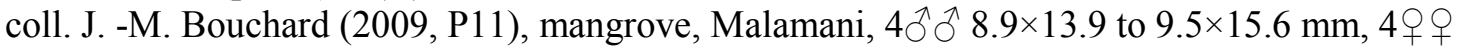
$8.0 \times 12.6$ to $8.5 \times 13.5 \mathrm{~mm}, \mathrm{MNHN}$ B32076, MNHN-IU-2009-995.

OTHER RECORDS - Macrophthalmus (Mareotis) depressus - Bouchard, 2009: 6, 28, Mayotte, same spp. than Mayotte KUW 2009.

GeOGRAPHIC AND DEPTH RANGES - WIO. Red Sea, Persian Gulf, Somalia, Kenya, Tanzania, Mozambique, South Africa, Mayotte (this fieldwork), Madagascar; supratidal, land.

\section{Macrophthalmus grandidieri A. Milne-Edwards, 1867}

MATERIAL EXAMINED - See Bouchard et al., 2013: 37, fig. 31 - Mayotte KUW 2009, st. 1, 7 $ぇ$ $6.2 \times 13.3 \mathrm{~mm}, 8.0 \times 16.5 \mathrm{~mm}, 1$ + $6.1 \times 12.0 \mathrm{~mm}, 1$ ov. $9.0 \times 18.6 \mathrm{~mm}, \mathrm{MNHN}$ B32077, MNHN-IU2009-996.

GeOGRAPHIC AND DEPTH RANGES - WIO. Red Sea, Somalia, Kenya, Tanzania, Mozambique, Mayotte (this fieldwork), South Africa, Madagascar; lower intertidal.

\section{Family Ocypodidae Rafinesque, 1815}

\section{Austruca annulipes (H. Milne Edwards, 1837)}

MATERIAL EXAMINED - See Bouchard et al., 2013: 41, fig. 35 as Uca (Austruca) annulipes - Mayotte KUW 2009, st. 2, intertidal, mangrove, Kangani, $1 \sigma^{\top} 6.3 \times 11.4 \mathrm{~mm}$, MNHN B32095, MNHN-IU-

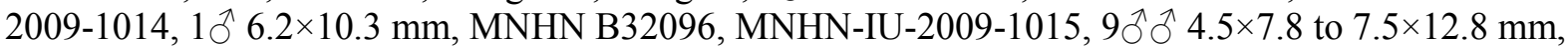
8 우우 (1 ov.) $4.2 \times 6.5$ to $6.5 \times 10.3 \mathrm{~mm}$, MNHN B32097, MNHN-IU-2009-1016; st. 6, Petite Terre, 'Déversoir Badamiers' 2 đo $5.5 \times 9.2 \mathrm{~mm}, 6.4 \times 10.5 \mathrm{~mm}, 2$ + $9+5.2 \times 8.8 \mathrm{~mm}, 6.5 \times 11.0 \mathrm{~mm}, \mathrm{MNHN}$ B32098, MNHN-IU-2009-1017; st. 13, mangrove (mixed with Paraleptuca chlorophthalmus and Cranuca inversa), Malamani, 11 ડิ $\widehat{0} 5.0 \times 8.3$ to $8.5 \times 14.0 \mathrm{~mm}$, MNHN B32099, MNHN-IU-20091018.

OTHER RECORDS - Uca annulipes - Guinot, 1967: 281, list with Mayotte. - Uca (Paraleptuca) annulipes - Bouchard, 2009: 6, 20, Mayotte, Malamani mangrove, coll. J. -M. Bouchard, 2008-2009, specimens added to Mayotte KUW 2009 collection, Malamani $\mathrm{n}^{\circ} 1-2,8$ 乃े $^{\widehat{o}} 3.5 \times 5.5$ to $7.7 \times 13.4 \mathrm{~mm}, 4$ 우

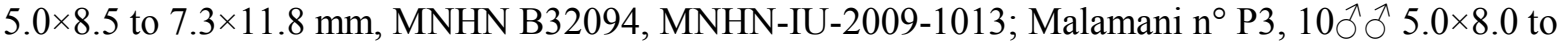
$8.5 \times 14.7 \mathrm{~mm}, \mathrm{MNHN}$ B32093, MNHN-IU-2009-1012.

REMARKS - For new generic classification, including Austruca, Cranuca, Gelasimus, Paraleptuca and Tubuca see Shih et al. (2016).

GEOGRAPHIC AND DEPTH RANGES - IWP, Mozambique, Tanzania, South Africa to Japan, Philippines, Samoa; supratidal. Red Sea Austruca annulipes now attributed to Uca (Austruca) albimana (Kossmann, 1877) by Naderloo et al. (2010). 


\section{Cranuca inversa (Hoffman 1874)}

MATERIAL EXAMINED - See Bouchard et al., 2013: 42, fig. 36 as Uca (Cranuca) inversa - Mayotte KUW 2009, Malamani mangrove coll. J. -M. Bouchard 2008-2009, Malamani $n^{\circ} 1-2,1 \delta^{\Uparrow} 11.6 \times 20.2$

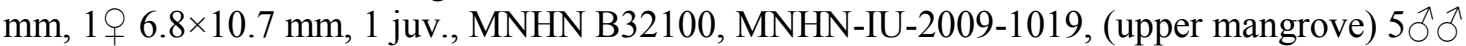
$6.5 \times 11.6$ to $10.8 \times 18.2 \mathrm{~mm}, 1$ juv., MNHN B32101, MNHN-IU-2009-1020; Malamani $\mathrm{n}^{\circ} \mathrm{P} 13$, P15, 9 万ै $6.5 \times 11.0$ to $13.2 \times 22.9 \mathrm{~mm}, 6$ 우 $5.2 \times 8.5$ to $10.7 \times 17.0 \mathrm{~mm}$, MNHN B32104, MNHN-IU-20091023; KUW 2009, st. 6, 'Déversoir Badamiers', Petite Terre, $3{ }^{\top} \widehat{\jmath} 7.8 \times 14.0,7.8 \times 13.4 \mathrm{~mm}$, and $7.4 \times 12.2 \mathrm{~mm}, \mathrm{MNHN}$ B32102, MNHN-IU-2009-1021; st. 13, mangrove, Malamani, 2 ○े $6.3 \times 10.3$ $\mathrm{mm}, 8.3 \times 14.7 \mathrm{~mm}, \mathrm{MNHN}$ B32103, MNHN-IU-2009-1022.

OTHER RECORDS - Uca (Cranuca) inversa - Bouchard, 2009: 6, 18, Mayotte, coll. J. -M Bouchard 20082009, Malamani mangrove, specimens added to KUW 2009 collection (see above).

GEOGRAPHIC AND DEPTH RANGeS - WIO, Red Sea, Yemen, Mayotte (this fieldwork), South Africa to Madagascar; supratidal.

\section{Gelasimus hesperiae (Crane, 1975)}

MATERIAL EXAMINED - See Bouchard et al., 2013: 43, fig. 37 as Uca (Gelasimus) hesperiae Crane, 1975 - coll. J. -M. Bouchard, 2008-2009, Malamani mangrove, Malamani ${ }^{\circ}$ P11, $1{ }^{\Uparrow} 12.2 \times 19.2$ mm, MNHN B32105, MNHN-IU-2009-1024; Mayotte KUW 2009, st. 2, mangrove, Kangani, $10^{\wedge}$ $11.0 \times 16.8 \mathrm{~mm}, 1$ ㅇ $12.5 \times 18.3 \mathrm{~mm}, \mathrm{MNHN}$ B32106, MNHN-IU-2009-1025, $1 \overbrace{}^{\Uparrow} 11.0 \times 17.3 \mathrm{~mm}$, MNHN B32107, MNHN-IU-2009-1026

OTHER RECORDS - Uca marioni marioni (Desmarest, 1823) - Guinot, 1967: 281, list with Mayotte / Accepted as Gelasimus vocans (Linnaeus, 1758) in WoRMS (2018) with 'U. vocans' from the Indian Ocean being now accepted as Gelasimus hesperiae (Crane, 1975) cf. Rosenberg $(2013,2014,2018)$, Shih et al. (2010). - Uca (Gelasimus) vocans - Bouchard, 2009: 6, 24, Mayotte, Malamani mangrove, specimens with Mayotte KUW collection (see above).

GEOGRAPHIC AND DEPTH RANGeS ( $c f$. Rosenberg, 2018) — IO, Gulf of Aden, Somalia, Mayotte, South Africa to India, Thailand; supratidal.

\section{Gelasimus tetragonon (Herbst, 1790)}

MATERIAL EXAMINED - See Bouchard et al., 2013: 44, fig. 38 as Uca (Gelasimus) tetragonon - Mayotte KUW 2009, st. 2, littoral from Trévani to Kangani Mangrove, 1 § $13.8 \times 20.8 \mathrm{~mm}, 2$ 우 $11.4 \times 17.2$ mm, 18.8×26.2 mm (ov.), MNHN B32108, MNHN-IU-2009-1027.

GEOGRAPHIC AND DEPTH RANGES - IWP, Iran, Red Sea, Tanzania, Kenya, Mayotte (this fieldwork) to Taiwan, Japan (Ryukyus), French Polynesia; supratidal.

\section{Ocypode ceratophthalmus (Pallas, 1772)}

MATERIAL EXAMINED - See Bouchard et al., 2013: 39, fig. 33 - Mayotte KUW 2009, st. 1, beach, Trévani, 3 đo $19.5 \times 22.5$ to $26.8 \times 31.0 \mathrm{~mm}, 2$ 우 $27.0 \times 31.5 \mathrm{~mm}, 33.0 \times 38.4 \mathrm{~mm}, 1$ juv. $10.5 \times 12.5 \mathrm{~mm}$, MNHN B32086, MNHN-IU-2009-1005; st. 2, intertidal from Trévani to Kangani Mangrove, 1 juv. $14.0 \times 16.8 \mathrm{~mm}$ (with hesitation, see remarks); st. 21a, Islet Choizil, field observation only, no specimens; st. 26, beach near Mutsumbatsou reef flat, 2 juv. (with hesitation); st. 29, beach, Mboianatsa, Ngouja Hotel, 2ðð $31.8 \times 37.7$ mm, 34.0×38.6 mm, MNHN B32085, MNHN-IU-20091004; st. 31, Bandrélé, 'Plage musicale', 1 juv. (with hesitation, see remarks); coll. Lisa, Tom and J. M. Bouchard, 05/01/2010, beach, Mliha, 5 juv., MNHN B32255, MNHN-IU-2009-1073; same collectors, upper beach of Ambato, $3 \mathrm{~km}$ from Mliha beach, 2 ते $13.6 \times 16.0 \mathrm{~mm}, 17.6 \times 20.6 \mathrm{~mm}, 2$ juv., MNHN B32256, MNHN-IU-2009-1074.

OTHER RECORDS - Poupin et al., 2013c: 12, Glorieuses, 1 juv. MNHN-IU-2013-7329. 
REMARKS - Juveniles of this species can be easily confused with Ocypode pallidula Hombron and Jacquinot, 1846 (see more comments in Bouchard et al., 2013).

GEOGRAPHIC AND DEPTH RANGES - IWP, Red Sea, Mayotte (this fieldwork), South Africa to Hawaii, French Polynesia, to Clipperton in the eastern Pacific; supratidal.

\section{Ocypode cordimanus Latreille, 1818}

MATERIAL EXAMINED - See Bouchard et al., 2013: 40, fig. 34 - Mayotte KUW 2009, st. 1, upper littoral,

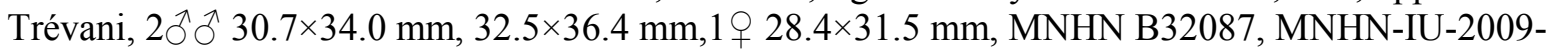
1006.

OTHER RECORDS - Poupin et al., 2013c: 12, Glorieuses.

GEOGRAPHIC AND DEPTH RANGES - IWP, Red Sea, Mayotte (this fieldwork), Mozambique to Japan, French Polynesia; supratidal, land. Records of this species in Hawaii have been corrected into Ocypode pallidula Hombron and Jacquinot, 1846 (see Castro, 2011)

\section{Paraleptuca chlorophthalmus (H. Milne Edwards, 1837)}

MATERIAL EXAMINED - See Bouchard et al., 2013: 45, fig. 39 as Uca (Paraleptuca) chlorophthalmus Mayotte KUW 2009, st. 13, mangrove, Malamani 15 ते $\widehat{\text { ते }} 6.7 \times 11.0$ to $10.4 \times 17.7 \mathrm{~mm}, 15$ ㅇ $95.3 \times 8.8$ to $10.0 \times 16.9 \mathrm{~mm}, \mathrm{MNHN}$ B32116, MNHN-IU-2009-1035.

OTHER RECORDS - Uca chlorophthalmus - Guinot, 1967: 281, list with Mayotte, Comoros (Anjouan, Grande Comore). - Uca (Tubuca) chlorophthalmus - Bouchard, 2009: 6, 22, Mayotte, coll. J. -M. Bouchard 2008-2009, Malamani mangrove, specimens added to KUW 2009 collection (st. 13b),

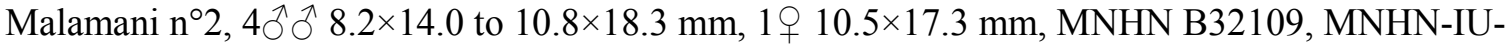
2009-1028; Malamani ${ }^{\circ} 3$, 1 đ 8.5×14.0 mm, 1 + 8.0×13.0 mm, MNHN B32110, MNHN-IU-20091029; Malamani $\mathrm{n}^{\circ} \mathrm{P} 35,1 \mathrm{O}^{\lambda} 7.4 \times 12.4 \mathrm{~mm}, 1$ + ov. $9.3 \times 15.3 \mathrm{~mm}, \mathrm{MNHN}$ B32111, MNHN-IU-20091030; ?Malamani, 6 우 $7.8 \times 13.0$ to $9.0 \times 14.7 \mathrm{~mm}$, MNHN B32112, MNHN-IU-2009-1031; Malamani

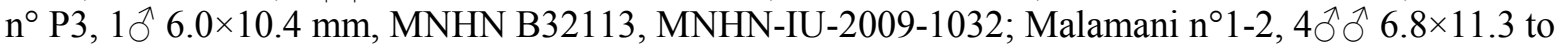
$10.8 \times 18.7 \mathrm{~mm}, 2$ 우 $6.2 \times 10.4 \mathrm{~mm}, 9.2 \times 15.0 \mathrm{~mm}$, MNHN B32114, MNHN-IU-2009-1033; Malamani

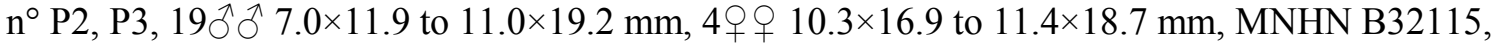
MNHN-IU-2009-1034. - Uca (Paraleptuca) chlorophthalmus - Shih et al., 2012: 36, Mayotte, coll.

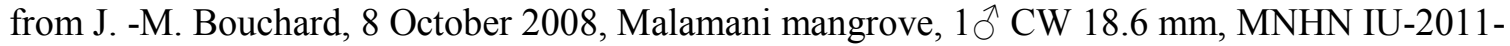
5599, 1 § CW $19.2 \mathrm{~mm}$, MNHN-IU-2011-5600, 1ठ CW $16.2 \mathrm{~mm}$, MNHN IU-2011-5601). - Shih et al., 2013: 643, tab. 1, 2 spp. MNHN (numbers not indicated) (loan from Mayotte KUW 2009 collection). - Paraleptuca chlorophthalmus - Shih et al., 2016: 173, Mayotte 2 spp. MNHN-IU-2011$5599,5600$.

GEOGRAPHIC AND DEPTH RANGES - WIO, Somalia, Kenya, Tanzania, Mayotte, Comoros (Anjouan, Grande Comore), Mozambique, South Africa to Madagascar, Réunion, Mauritius; supratidal, land.

\section{Tubuca urvillei (H. Milne Edwards, 1852)}

MATERIAL EXAMINED - See Bouchard et al., 2013: 46, fig. 40 as Uca (Tubuca) urvillei - Mayotte KUW 2009 , st. 13,15 त $12.8 \times 22.0$ to $18.8 \times 33.7 \mathrm{~mm}, 3$ 우 $12.2 \times 20.7$ to $14.8 \times 25.0 \mathrm{~mm}$ (photos in situ) MNHN B32092, MNHN-IU-2009-1011. 
OTHER RECORDS - Uca (Tubuca) urvillei - Bouchard, 2009: 6, 16, Mayotte, coll. J. -M. Bouchard, Malamani mangrove, $16 / 04 / 2008$, Malamani $n^{\circ} 3,12^{\circ} 55.415 \mathrm{~S}, 45^{\circ} 09.275 \mathrm{E}$, burrows near rill, $10{ }^{\lambda}{ }^{\lambda}$ $12.5 \times 22.0$ to $16 \times 28 \mathrm{~mm}, 2$ 우 $13.0 \times 22.5 \mathrm{~mm}, 13 \times 23.5 \mathrm{~mm}$, MNHN B32089, MNHN-IU-2009-1008;

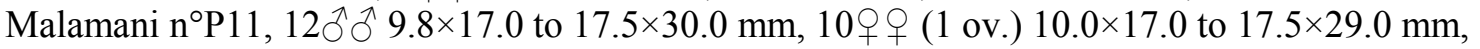

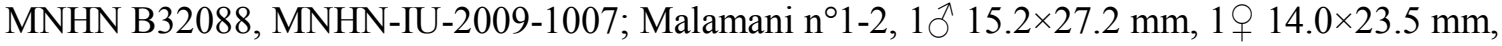
MNHN B32090, MNHN-IU-2009-1009; Malamani n 1-2, 1 ㅇ 8.3×13.8 mm, MNHN B32091, MNHN-IU-2009-1010. - Tubuca urvillei - Shih et al., 2016: 174, Mayotte, leg. from Mayotte KUW 2009, Poroani, ZRC 1999.1107.

GEOGRAPHIC AND DEPTH RANGES - WIO, Southern Somalia, Mayotte (this work), South Africa, Madagascar. Other records from Rea Sea, Pakistan, India, western Thailand attributed by Shih et al. (2018) to T. alcocki sp. nov.; supratidal, land.

\section{Superfamily Pinnotheroidea De Haan, 1833}

\section{Family Pinnotheridae De Haan, 1833}

?Nepinnotheres pectinicola (Bürger, 1895) (Figure 19K)

MATERIAL EXAMINED - Mayotte KUW 2009, st. 20b, western reef, Islet M'tzamboro, 10-15m, 1 $3.8 \times 4.4 \mathrm{~mm}$, in a small bivalve Pectinidae, MNHN-IU-2013-7238.

REMARKS - Without comparative material this single female is tentatively attributed to Nepinnotheres pectinicola by using the key Tesch (1918: 251). The dactylus of external maxilliped (MxP3), however, does not clearly 'overreach the propodus', leading to Pinnotheres obesus Dana, 1852 if the alternate entry 'not overreaching the propodus' is chosen. The carapace is quadrangular with a straight front. The dactyls of the ambulatory legs are falciform and sub-equal. The chelae are elongated with fringes of setae along inner faces of palm and dactyl a character observed in some Nepinnotheres by Manning (1993). Nepinnotheres pectinicola is reported by Tesch (1918) in 'Pecten radula', now Decatopecten radula (Linnaeus, 1758). According to H. R. Von Cosel (pers. comm., based on photo examination of the shell), however, the Pectinidae hosting the crab in Mayotte is not a Decatopecten but more probably a species of Laevichlamys Waller, 1993.

GEOGRAPHIC (from Schmitt et al., 1973) AND DEPTH RANGES — IWP, Gulf of Aden (Djibouti), ?Mayotte (present study) to Philippines; shallow water to $10-15 \mathrm{~m}$ (present study).

\section{DISCUSSION}

\section{Richness of the Crab Fauna}

In total 202 species of crabs are reported herein from the Mayotte KUW 2009 collection, a few of them such as Liomera albolineata, L. guttata, Linnaeoxantho acanthomerus, Platypodia morini and Xanthias cherbonnieri are not, or rarely, reported since their original description. To complement the KUW collection, 96 additional species records have been found in Mayotte region in the taxonomic literature making a total of 298 crabs (see Appendix). Mayotte KUW 2009 expedition appears as an important step for the study of the crab fauna of the island, almost doubling ( +138 new records) the previous number of species in the Island. This can be seen in Figure 20 where the documenting of crab new crab records from Mayotte region is plotted against time between 1870-2018 including the main collecting events and systematic contributions. 


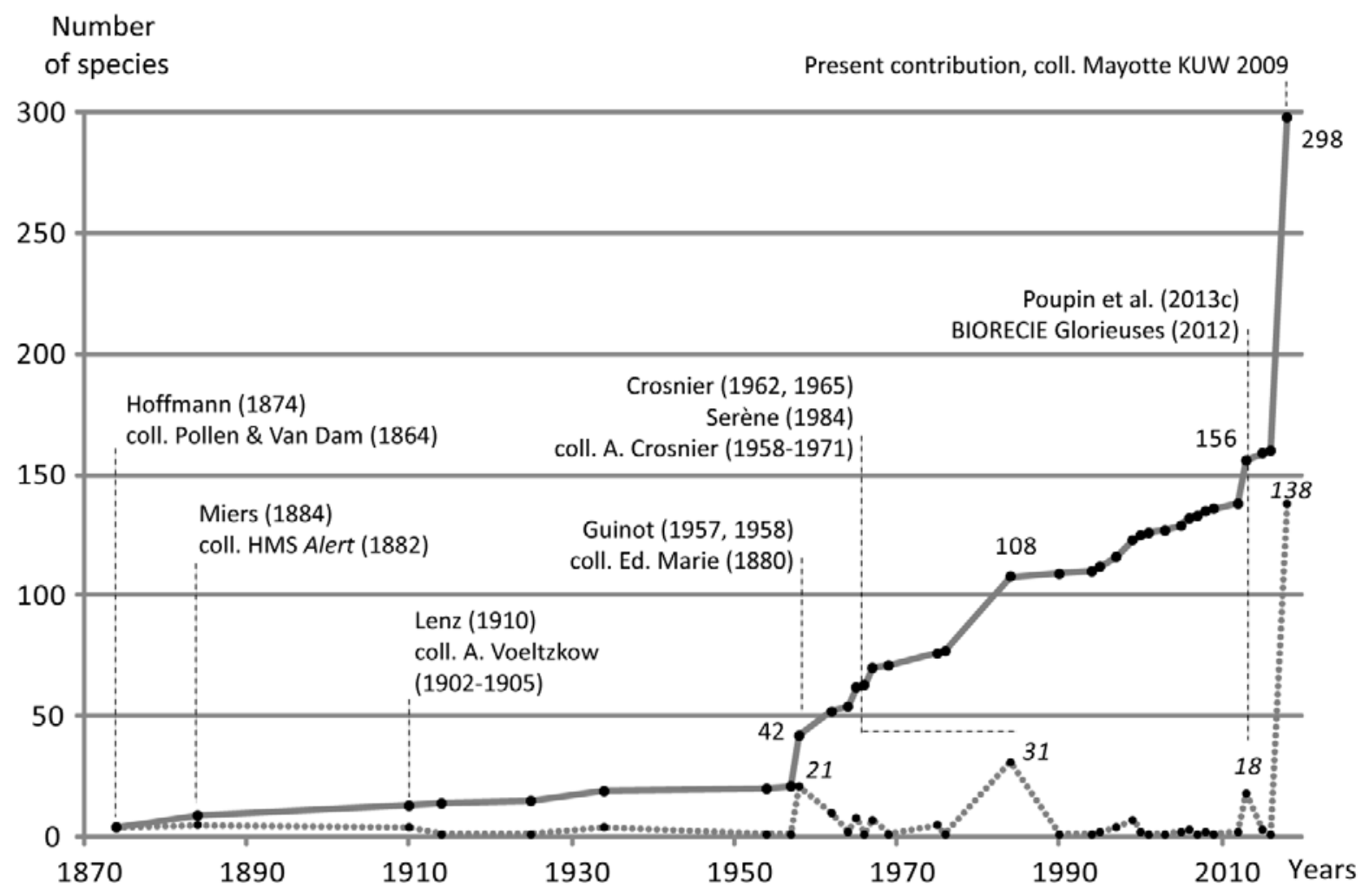

Figure 20. The documenting of new crab records in Mayotte region between 1864-2018, illustrating the importance of Mayotte KUW 2009 collection. Dotted line: number of new records by years. Solid line: cumulated number of new records. Main contributions and collecting events are indicated.

The number of species by family is presented in Table 1 and Figure 21. Six families are best represented accounting for about two third of the species (60\%): the Xanthidae (32\%), Portunidae (13\%), Epialtidae (4\%), Trapeziidae (4\%), Grapsidae (4\%) and Leucosiidae (3\%).

Table 1. Crabs of Mayotte region. Number of species inventoried for each family (light grey for families represented by less than 10 species)

\begin{tabular}{|l|c|l|c|l|c|}
\hline Family & $\mathrm{n}$ & Family & $\mathrm{n}$ & Family & $\mathrm{n}$ \\
\hline Xanthidae & 95 & Pilumnidae & 5 & Latreillidae & 2 \\
\hline Portunidae & 39 & Tetraliidae & 5 & Matutidae & 2 \\
\hline Epialtidae & 12 & Calappidae & 4 & Plagusiidae & 2 \\
\hline Trapeziidae & 12 & Dynomenidae & 4 & Aphanodactylidae & 1 \\
\hline Grapsidae & 11 & Eriphiidae & 3 & Carpilidae & 1 \\
\hline Leucosiidae & 10 & Goneplacidae & 3 & Crossotonotidae & 1 \\
\hline Ocypodidae & 9 & Palicidae & 3 & Cyclodorippidae & 1 \\
\hline Dromiidae & 8 & Percnidae & 3 & Dairidae & 1 \\
\hline Macrophthalmidae & 8 & Acidopsidae & 2 & Dotillidae & 1 \\
\hline Sesarmidae & 8 & Aethridae & 2 & Ethusidae & 1 \\
\hline Majidae & 7 & Domeciidae & 2 & Euryplacidae & 1 \\
\hline Varunidae & 7 & Gecarcinidae & 2 & Pinnotheridae & 1 \\
\hline Oziidae & 7 & Homolidae & 2 & Planopilumnidae & 1 \\
\hline Parthenopidae & 6 & Inachidae & 2 & Pseudoziidae & 1 \\
\hline
\end{tabular}




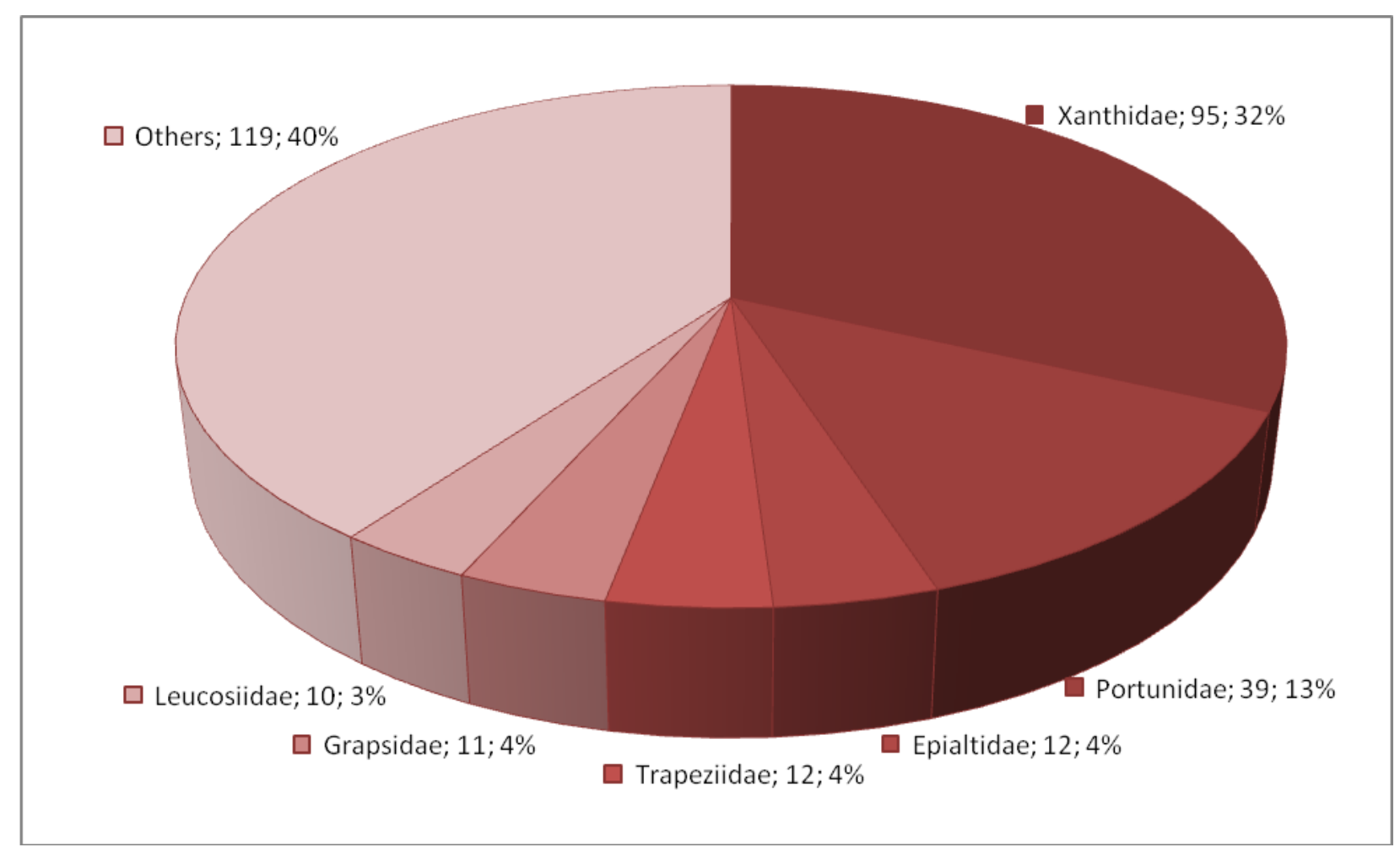

Figure 21. Most important crab families for the inventory in Mayotte region. Family names and exact figures for 'Others' are in Table 1 in light grey).

\section{Zoogeography}

The number of species in Mayotte region is presented in Table 2 by main zoogeographic provinces. The crab fauna of the Island is predominantly IWP in its composition counting for almost $80 \%$ of the species from this province. About $17 \%$ of the species are restricted to the IO (IO + WIO) of which about $83 \%$ are only in the WIO sensu Serène (1984; west of $75^{\circ} \mathrm{E}$, see Figure 2). Only seven species have an IP distribution, reaching to the western American coasts: Domecia hispida, Liomera cinctimana, Plagusia immaculata, P. squamosa, Trapezia bidentata, T. digitalis, and T. formosa. A single species has a worldwide distribution, being also present in the Atlantic, the pelagic crab Planes major. Six additional species can be added to the 'worldwide group' being IWP species invasive to the Mediterranean (and sometimes WA): Carupa tenuipes, Charybdis hellerii (also in WA), Coleusia signata, Latopilumnus malardi (also English Channel, but not established), Plagusia squamosa, and Thalamita gloriensis.

\begin{tabular}{|l|c|}
\hline \multicolumn{1}{|c|}{$\begin{array}{c}\text { Zoogeographic } \\
\text { provinces }\end{array}$} & $\begin{array}{c}\text { Number of } \\
\text { species }\end{array}$ \\
\hline Indo-West Pacific (IWP) & 238 \\
\hline Western Indian Ocean (WIO) & 43 \\
\hline Indian Ocean (IO) & 9 \\
\hline Indo-Pacific (IP) & 7 \\
\hline Worldwide & 1 \\
\hline \multicolumn{1}{|c|}{ Total } & $\mathbf{2 9 8}$ \\
\hline
\end{tabular}

Table 2. Number of crabs reported in Mayotte region by zoogeographic provinces. 
Six species of western and/or central Pacific are reported in the IO for the first time in this work: Aethra edentata, Kabutos durandi, Lahaina incerta, Liomera albolineata, Lophozozymus edwardsi, and Paramedaeus octogesimus. Three species are new WIO records: Actaea spinosissima, western limit extended from Cargados Carajos (Mauritius); Huenia ?brevifrons, western limit extended from Maldives and Laccadives Islands; Pilumnus ?fissifrons, western limit extended from Western Australia.

\section{Taxonomic Issues}

Many taxonomic issues remain unresolved in this study. More refined taxonomic revisions are required to improve the present contribution. Some of the taxonomic issues encountered during this work are summarized below:

- Species determined with hesitation, no comparison specimens being examined and/or specimens being juveniles: ?Caecopilumnus piroculatus, ?Hiplyra elegans, Huenia ?brevifrons, Pilumnus ?fissifrons, P. aff. turgidulus, Tetralia ?nigrolineata; ?Nepinnotheres pectinicola; Thalamita ?mitsiensis.

- Species in need of revision (Morphological/color variations indicate complex of species): Paramedaeus simplex s.1., Portunus longispinosus s.1., Tetralia glaberrima s.1.; Tetralia rubridactyla s.l.; Lophozozymus pulchellus s.l. (live color pattern variable); Menaethiops brevicornis (differences between M. brevicornis, M. acutifrons, and M. bicornis unclear); Monodaeus tuberculidens s.1.; Paractaea rufopunctata s.1.; Parasesarma leptosoma s.1.; Xanthias cherbonnieri s.l. (live color pattern variable); X. maculatus s.l. (live color pattern variable).

- Congeneric species that remains difficult to recognized with need to examine sets of specimens for better appreciating morphological variations with size for a lot of them (some are potential synonyms): Aethra edentata / A. scruposa; Liocarpilodes armiger / L. pacificus; Lydia annulipes / L. tenax; Lybia plumosa / L. leptochelis; Etisus odhneri / E. demani; Micippa thalia / M. xishaensis; Neoliomera themisto / N. richtersi; Neosarmatium meinerti / N. africanum; Nucia speciosa / N. rosea; Parapilumnus cristimanus / P. oryctos; Tweedieia laysani / T. odhneri; Xanthias maculatus / X. joanneae.

- Revision of genera: Liomera guttata, different from all Liomera species; could warrant new genus; Linnaeoxantho acanthomerus, similar to Melybia thalamita Stimpson, 1871 in WA, but distinct generic placement for these two species perhaps not justified.

- Two species were not included in the present contribution because no satisfying determination can be proposed at genus level. These are however registered in MHNN collection pending

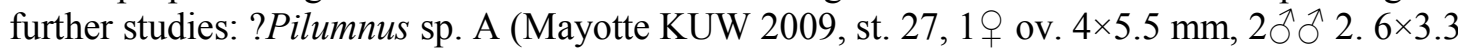
$\mathrm{mm}, 4.1 \times 5.4 \mathrm{~mm}$, MNHN-IU-2013-7233; Figure 19M); and ?Pilumnus sp. C. (Mayotte KUW 2009, st. 20b, 1 4 4.2×5.4 mm MNHN-IU-2013-7235; Figure $19 \mathrm{~N}$ ).

\section{Ongoing Studies on Deep Water Collections in the Region (MIRIKY 2009, BIOMAGLO 2017)}

The number of crab species by deep ranges is reviewed in Table 3. Most of the species (200 spp. $67 \%$ ) are from the shallow waters of the lagoon that were prospected during KUW 2009. Species from 'Shallow to deep-waters' (31 spp. $\sim 10 \%$ ) are most often reported in shallow waters but with some much deeper records indicating that they have a wide depth range (i.e. Aethra scruposa 1-200 m; Calappa gallus 1-216 m; Laleonectes nipponensis, 15-250 m; Tumidodromia dormia 6-156 m, etc.). Only 11 species are 'deep species' being always reported in waters greater than $100 \mathrm{~m}$ : Alcomaja miriky, Corycodus spinosus, Ethusa sinespina, Hyastenus uncifer, Metadynomene crosnieri, Paramaja gibba, Paromolopsis boasi, Pseudopalicus sexlobatus, Pycnoplax coryphaea, Sakaija africana, and Sphenomerides trapezioides. The two pelagic species reported are Charybdis smithii, observed in large oceanic swarms, and the 'oceanic crab' Planes major. 


\begin{tabular}{|l|c|}
\hline Deep range & $\begin{array}{c}\text { Number of } \\
\text { crab species }\end{array}$ \\
\hline Land and Freshwater & 17 \\
\hline Intertidal & 37 \\
\hline Shallow-waters $(0-100 \mathrm{~m})$ & 200 \\
\hline Shallow to deep-waters (e.g. 10-190 m) & 31 \\
\hline Deep (more than $100 \mathrm{~m})$ & 11 \\
\hline Pelagic or bathypelagic & 2 \\
\hline Total & $\mathbf{2 9 8}$ \\
\hline
\end{tabular}

Table 3. Number of crab species in Mayotte region by depth ranges.

The results of Table 3 show that the deep fauna is poorly represented in the present inventory in Mayotte region. The three main oceanic campaigns having collected deep Decapoda in the region are shown below (Figure 22) with these campaigns being also presented in BasExp (2018). While the Decapoda collection found in 1977 has been already studied in several contributions those undertaken in 2009 and 2017 require investigation. Undoubtedly they will create many new records for the region.

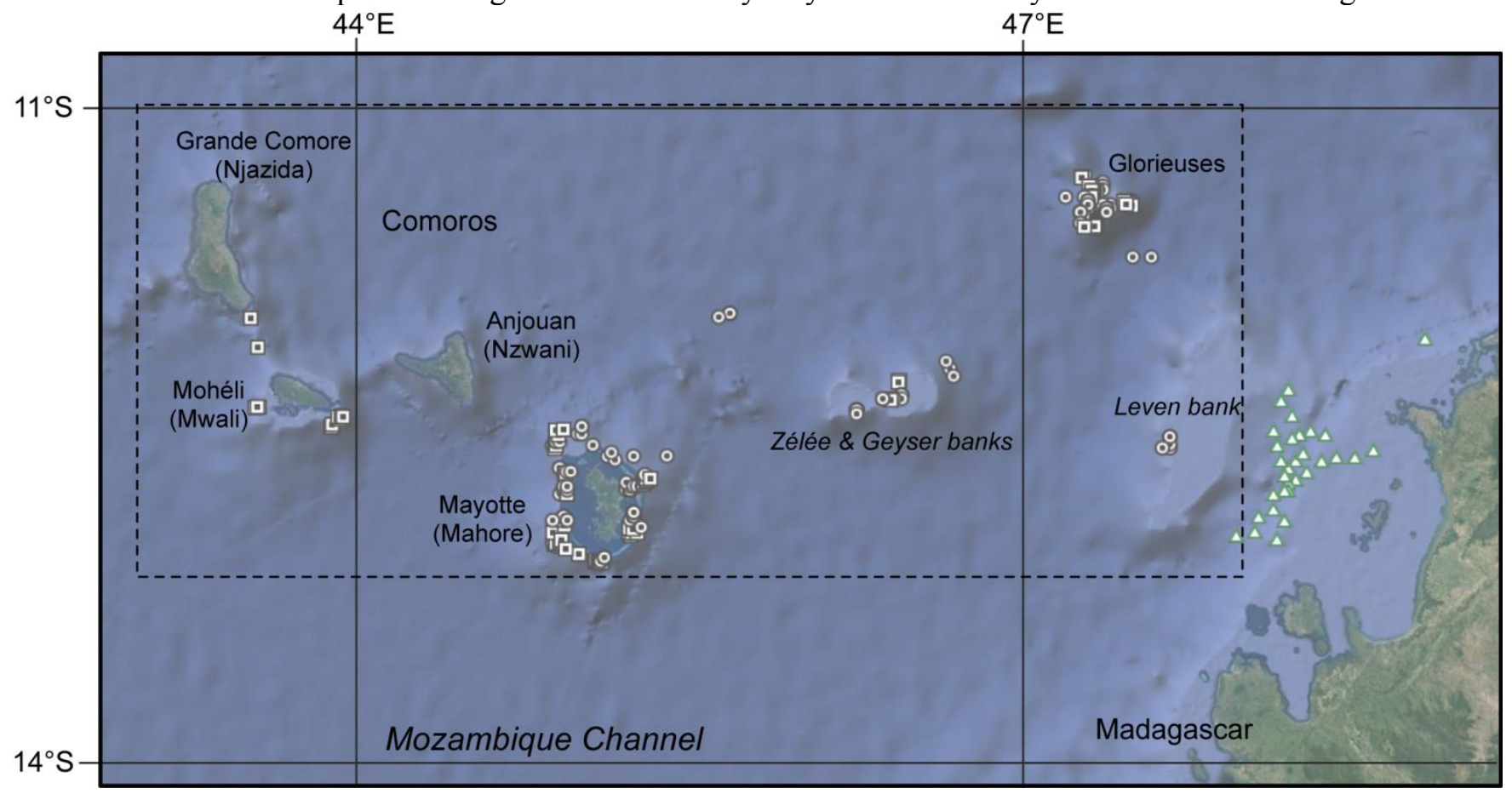

Figure 22. Mayotte region as defined for this inventory (dotted line, $11-13^{\circ} 10^{\prime} \mathrm{S}, 43-48^{\circ} \mathrm{E}$ ), including Comoros Islands, Mayotte, Glorieuses Islands and three marine banks (Zélée, Geyser, Leven). Deep stations sampled at sea $(\sim 100-1000+\mathrm{m})$ are indicated for three oceanographic campaigns realized for this region: BENTHEDI 1977 (circles), MIRIKY 2009 (green triangles, only for stations $<13^{\circ} \mathrm{S}$ ) and BIOMAGLO 2019 (squares).

- BENTHEDI 1977 - R/V Suroitt with 107 stations in Mayotte region (Figure 22, circles). From this campaign Poupin (2015) has identified a total of 47 Decapoda including four brachyuran crabs, 1 Goneplacidae in Guinot (1990), 2 Homolidae in Guinot and Richer de Forges (1995) and 1 Dynomenidae in McLay (1999).

- MIRIKY 2009 - Shrimp trawler Miriky with 119 stations in the northeast of Madagascar of which only 32 situated north of $13^{\circ} \mathrm{N}$, near the Leven bank, in the vicinity of Mayotte region (Figure 22, green triangles). Decapoda from this collection have been partly studied with only a few records near Mayotte region (north of $13^{\circ} \mathrm{S}$ ) included in the present inventory: 12 crabs 
Crossotonotidae, Ethusidae, Euryplacidae, Goneplacidae, Latreilliidae, Palicidae, Tetraliidae, and Trapeziidae in Castro (2012, 2013); 1 crab Cyclodorippidae in Naruse (2013); and 3 crabs Majidae in Ng and Richer de Forges (2015).

- BIOMAGLO 2017 - R/V Antea with 89 stations in Mayotte region (Figure 22, squares) with an unstudied collection of Decapoda.

\section{How Many Crabs Are There in Mayotte Region: 600?}

The discovery rate of crabs in Mayotte region is presented in Figure 23. The best fitting curve is exponential (vertical axis is logarithmic) without asymptotic limit in the recent years, that could indicate a saturation in the discovery rate during the latest decades, and the time for 'half discovery' is recent (20122013). These observations are an indication that much more species remain to be discovered in Mayotte region that is strategically positioned at the entrance to the Mozambique Channel and with a wide range of biomes from mangroves, corals, reefs, rocky shores, seagrass meadows, sandy beaches to freshwater and terrestrial biomes where the diversity of the species is very high.

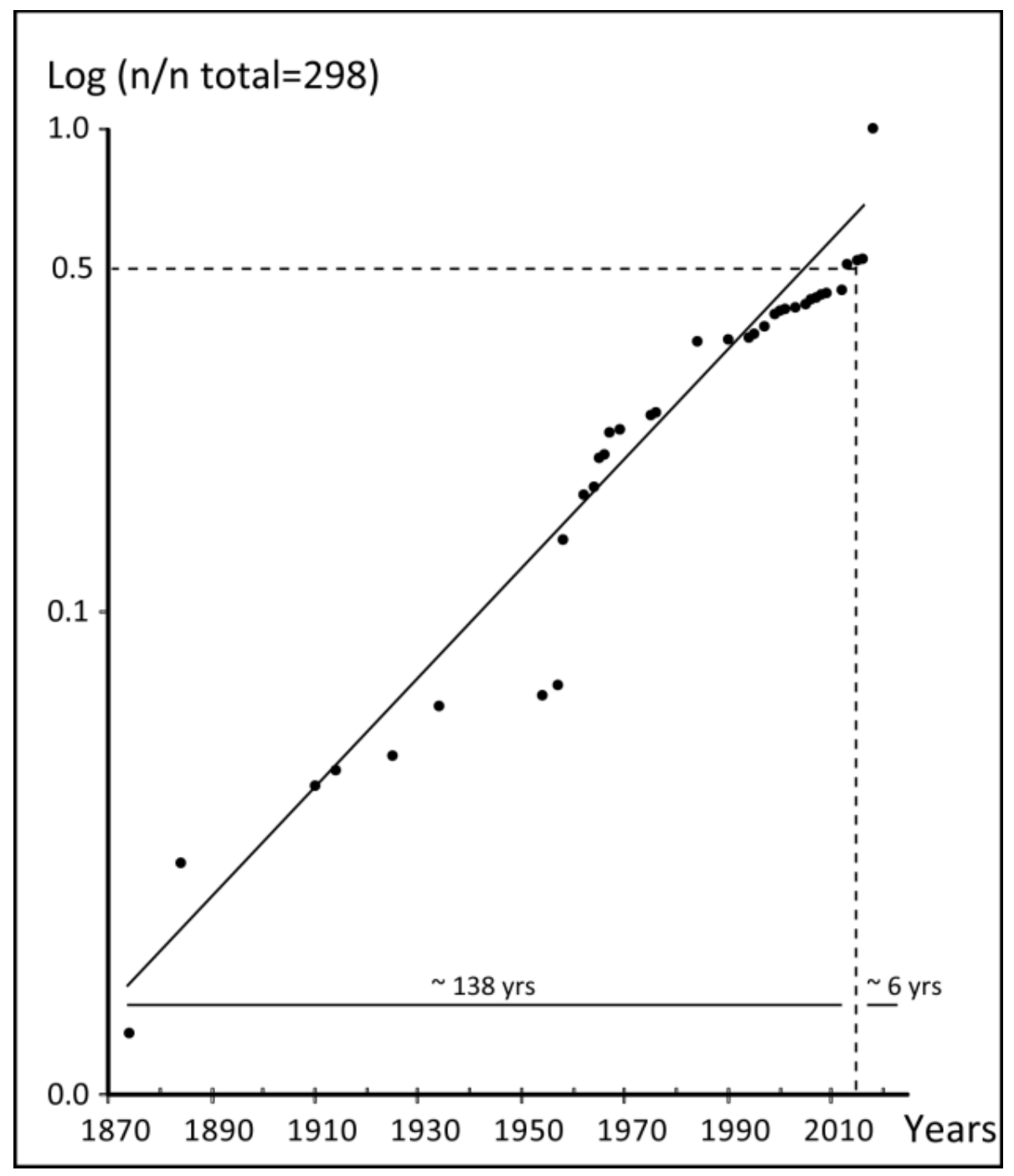

Figure 23. Discovery rate for the species of Decapoda in Mayotte region between 1874-2018. The discovery rate (vertical axis in logarithmic scale) is the ratio of number of species (n) / total number of species (298), plotted against time (horizontal axis, years). Dotted lines indicate the time when half of the records ( 0.5 or 149 species) has been reached $(2012 / 13)$ 
The total number of crab in the region can be estimated by comparison with more global inventories in the IO, these including the deep species that are poorly represented in the present contribution:

- For WIO French overseas territories the database of Legall and Poupin (2018) includes 437 crabs in Mayotte region and Islands of Europa, Juan de Nova, Réunion. Potentially all these species could be present in the region which means ca. +140 species.

- For Namibia, South Africa and Mozambique, Emmerson (2016) 'Guide and Checklist' reports about 460 crabs.

- For WIO, including Red Sea and IO west of $75^{\circ}$ E, Serène (1984) indicates 280 brachyuran crabs Xanthidae and Trapeziidae to be compared to only $\sim 110$ in the present study (95 Xanthidae, 12 Trapeziidae), that is about $\times 2.5$ more taxa. If this figure is applied to the whole crab fauna, Mayotte region could have as much as $2.5 \times 298=745$ species.

- In WoRMS (2018), consulted during the preparation of this contribution, the number of valid crabs species in IO is $\sim 600$ species.

From these examples it appears that the estimation of the total number of crabs in Mayotte region is still speculative. It is, however, realistic to consider that the number of crabs in this region may be about twice as for the present inventory; that is $\sim 600$ species. This figure is consistent with other IWP regions, e.g. Australia, the 'Zoological catalogue' (Davie, 2002) with 969 species; Taiwan, 'Annotated checklist' (Ng et al., 2001) with 548 species including the caveat that 'the brachyuran fauna for Taiwan and its associated islands will probably approach 700 species when more surveys and studies have been completed'; Japan and adjacent seas (Sakai, 2004) with 'some 1250 species and subspecies of brachyuran crabs'; French overseas territories of New Caledonia and French Polynesia (database of Legall and Poupin, 2018) with 640 and 480 valid species, respectively; and the Hawaiian Islands (Castro, 2011), which are more isolated and probably have an impoverished fauna, with 284 'reliably identified' species.

\section{ACKNOWLEDGMENTS}

Financial support for this study has been obtained from the Direction de l'Agriculture et de la Forêt of Mayotte (DAF) and Total Foundation. Supplementary assistance for this research has been given by the École Navale, Brest and the Muséum national d'Histoire naturelle, Paris (MNHN).

In MNHN Paris the registration of the collection was begun by R. Cleva, R. Kebir and J. Poupin, using the old handwritten catalogs (e.g. B32251). It was continued and computerized (e.g. MNHN-IU2009-1069) by P. Martin Lefèvre with assistance of R. Kebir, A. Sato and S. Soubzmaigne.

Photographs of some species were obtained via several collaborators, by alphabetical order: Lionel Bigot, Matthias Deuss, François Fromard, Yvon Gildas, Christian Hily, Matthieu Leray, J. -B. Nicet, Ngan Kee Ng, Benjamin Pineau, Norbert Verneau.

Several determination were made or corrected by P. Castro (Trapeziidae), D. Guinot (Dromiidae, Majidae, Parthenopidae), P.K.L. Ng (Leucosiidae, Pilumnidae), and N. Naderloo (Nanosesarma).

The draft manuscript has been improved by suggestions and corrections of Paul Clark and Winston Emmerson. 


\section{REFERENCES}

Ahyong, S. T., and P. K. L. Ng. 2009. Aphanodactylidae, a new family of thoracotreme crabs (Crustacea: Brachyura) symbiotic with polychaete worms. Zootaxa, 2289: 33-47.

Apel, M., and V. A Spiridonov. 1998. Taxonomy and zoogeography of the portunid crabs (Crustacea: Decapoda: Brachyura: Portunidae) of the Arabian Gulf and adjacent waters. Fauna of Arabia, 17: 159-331.

Balss, H. 1934. Sur quelques Décapodes brachyoures de Madagascar. Faune des Colonies Françaises, Contribution à l'étude des crustacés de Madagascar, 5(8): 501-528.

Barnard, K. H. 1950. Descriptive Catalogue of South African Decapod Crustacea (crabs and shrimps). Annals of the South African Museum, 38: 1-837.

-1954. Notes sur une collection de crustacés décapodes de la région malgache. Mémoires de l'Institut Scientifique de Madagascar, 9: 95-104.

- 1955. Additions to the fauna-list of south African Crustacea and Pycnogonida. Annals of the South African Museum 43 (1): 1-107.

BasExp, 2018 Référentiel des campagnes du Muséum national d'Histoire naturelle, Paris. https://expeditions.mnhn.fr/. Consulté en Janvier 2018

Borradaile, L. A. 1902. Marine Crustaceans, III. The Xanthidae and some others crabs. In Gardiner J. S. (Ed.) The Fauna and Geography of the Maldive and Laccadive Archipelagoes, 1 (3): 237-271.

Bouchard, J. -M. 2009. Crabes de Mangrove. Étude systématique réalisée sur le site de Malamani (Mayotte). Résultats préliminaires de la mission d'inventaire des Crustacés Décapodes de Mayotte. Rapport KUW/DAF réalisé dans le cadre du projet " Mangrove et bioremédiation. Un projet-pilote à Mayotte pour le traitement d'eaux usées domestiques »: 1-31. À http://crustaceamayotte.free.fr/pdf/bouchard-2009-mangrove-malamani.pdf

Bouchard, J. -M., J., Poupin, R., Cleva, J. Dumas, and V. Dinhut. 2009. Rapport de mission du 2 au 22 novembre. Mission Crustacés Mayotte 2009. Rapport Kraken Underwater Works, KUW, Mamoudzou, Mayotte: 1-151. À http://crustaceamayotte.free.fr/ (Bibliographie en trois PDF).

- 2013. Land, mangrove and freshwater decapod crustaceans of Mayotte region (Crustacea, Decapoda). Atoll Research Bulletin, 592: 1-69. At http://opensi.si.edu/index.php/smithsonian/catalog/book/33

Boyko, C. B., and A. Liguori. 2015. Grapsoid and Gall Crabs (Crustacea: Brachyura: Grapsoidea and Cryptochiroidea) of Easter Island. Pacific Science, 69 (4): 509-523.

Buitendijk, A. M. 1939. Biological results of the Snellius Expedition. V - The Dromiacea, Oxystomata, and Oxyrhyncha of the Snellius Expedition. Temminckia, 4: 224-276.

Castro, P. 1997. - Trapeziid crabs (Brachyura, Xanthoidea, Trapeziidae) of New Caledonia, eastern Australia, and the Coral Sea. In, Richer de Forges B. (Ed.), Les fonds meubles des lagons de Nouvelle-Calédonie (Sédimentologie, Benthos). Études and Thèses ORSTOM, 3: 59-107. At http://www.documentation.ird.fr/hor/fdi:010013924

- 1998. Systematic status and geographic distribution of Trapezia formosa Smith, 1869 (Crustacea, Brachyura, Trapeziidae), a symbiont of reef corals. Zoosystema, 20 (2): 177-181.

- 1999a. Trapeziid crabs (Crustacea, Brachyura, Xanthoidea, Trapeziidae) of the Indian Ocean and the Red Sea. Zoosystema, 21 (1): 93-120.

- 1999b. Results of the Rumphius biohistorical Expedition to Ambon (1990). Part 7. The Trapeziidae (Crustacea: Brachyura: Xanthoidea) of Indonesia. Zoological Mededelingen, 73 (3): $27-$ 61.

. 2000. Crustacea Decapoda: A revision of the Indo-West Pacific species of palicid crabs (Brachyura Palicidae). In, Crosnier A. (Ed.), Résultats des campagnes MUSORSTOM, volume 21. Mémoires du Muséum national d'Histoire naturelle, 184: 437-610.

- 2011. Catalog of the anomuran and brachyuran crabs (Crustacea: Decapoda: Anomura, Brachyura) of the Hawaiian Islands. Zootaxa, 2947: 1-154. 
2012. - Goneplacid crabs (Brachyura, Goneplacidae) of the MAINBAZA and MIRIKI expeditions to the Mozambique Channel, with the description of a new species of Pyncoplax Castro, 2007. Crustaceana Monographs, 17: 91-104.

2013. Brachyuran crabs (Crustacea, Brachyura: Crossotonotidae, Ethusidae, Euryplacidae, Goneplacidae, Latreilliidae, Palicidae, Tetraliidae, Trapeziidae) of the MAINBAZA, MIRIKI, and ATIMO VATAE Expeditions to the Mozambique Channel and Madagascar. In, Ahyong S. T., Chan T. Y., Corbari L. and Ng P. K. L. (Eds), Tropical Deep-Sea Benthos volume 27. Mémoires $d u$ Muséum national d'Histoire naturelle, 204: 437-466.

Chen, H. 1979. Two new species of crabs from the Xisha islands, Guangdong province, China. Oceanologica et Limnologia Sinica, 10 (1): 77-81.

Clark, P. F. and B. S. Galil. 1993. A revision of the xanthid genus Pilodius Dana, 1851 (Crustacea: Brachyura: Xanthoidea). Journal of Natural History, 27: 1119-1206.

Cleva, R., D., Guinot, and L. Albenga. 2007. Annotated catalogue of brachyuran type specimens (Crustacea, Decapoda, Brachyura) deposited in the Muséum national d'Histoire naturelle, Paris. Part I. Podotremata. Zoosystema, 29 (2): 229-279.

Crosnier, A. 1962. Crustacés Décapodes Portunidae. Faune de Madagascar, 16: 1-154. . 1965. Crustacés Décapodes Grapsidae et Ocypodidae. Faune de Madagascar, 18: 1-143. 1975. Sur quelques Portunidae, Grapsidae et Ocypodidae (Crustacea Decapoda Brachyura) de Madagascar ou des îles avoisinantes, nouveaux, rares ou non encore signalés. Bulletin du Muséum national d'Histoire naturelle, 214: 711-741.

- 1984. Famille des Carpiliidae et des Menippidae. In, Serène R., 1984, Crustacés Décapodes Brachyoures de l'océan Indien occidental et de la mer Rouge. Xanthoidea: Xanthidae et Trapeziidae. Faune Tropicale, 24: 299-313.

- 2002. Portunidae (Crustacea, Decapoda, Brachyura) de Polynésie française, principalement des îles Marquises. Zoosystema, 24 (2): 401-449.

Crosnier, A., and M. K. Moosa. 2002. Trois Portunidae (Crustacea, Decapoda, Brachyura) nouveaux de Polynésie française. Zoosystema, 24 (2): 385-399.

Crosnier, A., and B. Thomassin. 1975. Sur des crabes de la famille des Portunidae (Crustacea Decapoda) nouveaux pour Madagascar ou rares. Bulletin du Muséum national d'Histoire naturelle, 1974 (1975), 165: $1097-1118$.

Davie, P. J. F. 2002. Crustacea: Malacostraca: Eucarida (Part 2): Decapoda - Anomura, Brachyura. In Wells A. and Houston W.W.K. (eds) Zoological Catalogue of Australia. CSIRO Publishing, Melbourne, 19 (3B): i-xiv, 1-641.

Dana, J. D. 1855. Crustacea. United States Exploring Expedition during the years 1838, 1839, 1840, 1841, 1842. Atlas, 13: 1-27, pl. 1-96.

De Grave, S., N.D. Pentcheff, S. T. Ahyong, T. -Y. Chan, K. A. Crandall, P. C. Dworschak, D. L. Felder, R. M. Feldmann, C. H. J. M. Fransen, L. Y. D. Goulding, R. Lemaitre, M. E. Y. Low, J. W. Martin, P. K. L. Ng, C. E. Schweitzer, S. H. Tan, D. Tshudy, and R. Wetzer. 2009. A classification of living and fossil genera of decapod crustaceans. The Raffles Bulletin of Zoology, supplement 21: 1-109. At https://decapoda.nhm.org/references/referenceinfo.html?refid=31051

Della Croce, N., and L. B. Holthuis. 1965. Swarming of Charybdis (Goniohellenus) edwardsi Leene and Buitendijk in the Indian Ocean (Crustacea, Decapoda, Portunidae). Bollettino del Musei e degli Istituti Biologici dell'Università di Genova (1964-1965), 33 (199): 33-38.

De Man, J. G. 1888. Bericht über die im indischen Archipel von Dr. J. Brock gesammelten, Dekapoden und Stomatopoden. Archiv für Naturgeschichte, 53: 215-600.

- 1913. Sur une nouvelle observation de crabes habitant les coquilles vides des balanes. Bulletin $d u$ Muséum d'Histoire naturelle, 1: 9-11.

- 1914. Description de deux espèces nouvelles du Genre Pilumnus Leach et d'une jeune femelle du Pil. longicornis Hilgd., découvertes dans des coquilles vides de balanes. Bulletin de la Société zoologique de France, 39: 330-343.

Dérijard, R. 1966. Note préliminaire sur les crustacés Stomatopodes et Décapodes récoltés à l'île Europa du 6 au 24 avril 1964. Mémoire du Muséum national d'Histoire naturelle, 41: 159-180. 
Emmerson, W. D. 2016. A Guide to, and Checklist for, the Decapoda of Namibia, South Africa and Mozambique. Cambridge Scholars Publishing: Volume 1: 1-590, Volume 2: 1-650, Volume 3: 1720.

Evans, N. 2018. Molecular phylogenetics of swimming crabs (Portunoidea Rafinesque, 1815) supports a revised family-level classification and suggests a single derived origin of symbiotic taxa. PeerJ, 6: e4260. http://dx.doi.org/10.7717/peerj.4260.

Ferry, R., Y. Buske, J. Poupin, and J. Smith. 2017. First record of the invasive swimming crab Charybdis hellerii (A. Milne Edwards, 1867) (Crustacea, Portunidae) off Martinique, French lesser Antilles. BioInvasions Records, 6 (3): 239-247. At http://www.reabic.net/journals/bir/2017/Issue3.aspx

FLMNH 2018. Florida Museum of Natural History, Invertebrate Zoology Collection. At http://specifyportal.flmnh.ufl.edu/iz/. Consulted 2018.

Forest, J., and D. Guinot. 1961. Crustacés Décapodes Brachyoures de Tahiti et des Tuamotu. In, Expédition française sur les récifs coralliens de la Nouvelle Calédonie. Volume préliminaire, Paris, Editions de la Fondation Singer Polignac, 9-11: 1-195.

Fourmanoir, P. 1952. Observations sur la faune marine et la pêche à l'île Europa. Mémoires de l'Institut Scientifique de Madagascar, 7 (2): 167-188.

Galil, B. S. 2001. A revision of Myra Leach, 1817 (Crustacea: Brachyura: Leucosioidea). Zoologische Verhandelingen, 75 (24): 409-446.

. 2003. Four new genera of leucosiid crabs (Crustacea: Brachyura: Leucosiidae) for three new species and nine species previously in the genus Randallia Stimpson, 1857, with a redescription of the type species, R. ornata (Randall, 1939). Proceedings of the Biological Society of Washington, 116 (2): $395-422$.

- 2005. Contributions to the knowledge of Leucosiidae III. Urnalana gen. nov. (Crustacea: Brachyura). Zoologische Mededelingen, 79-2 (2): 9-40.

- 2006. Contributions to the knowledge of Leucosiidae V. Coleusia gen. nov. (Crustacea: Brachyura). Zoologische Mededelingen, 80-4 (5): 55-69.

. 2009. An examination of the genus Philyra Leach, 1817 (Crustacea, Decapoda, Leucosiidae) with descriptions of seven new genera and six new species;. Zoosystema, 31 (2): 279-320.

Galil, B. S., and G. Innocenti. 2002. A note on coral rubble mimetic leucosiid crabs from Kenya. Atti della Società Italiana di Scienze Naturali, 142 (2): 201-205.

Galil, B. S., and M. Takeda. 1988. A revision of the genus Glabropilumnus (Crustacea, Decapoda, Brachyura). Bulletin of the National Science Museum Tokyo, 14 (2): 67-90.

Galil, B. S., and M. Vannini. 1990. Research on the coast of Somalia. Xanthidae, Trapeziidae, Carpiliidae, Menippidae (Crustacea, Brachyura). Tropical Zoology, 3: 21-56.

Galil, B. S., C. Froglia, and P. Y. Noël. 2018. CIESM Atlas of Exotic Crustaceans in the Mediterranean Sea. Check-list of exotic species. At http://www.ciesm.org/atlas/appendix2.html. Consulted January 2018.

GBIF 2018 Thalamita pseudospinifera Crosnier, 1975 in GBIF Secretariat (2017). GBIF Backbone Taxonomy. Checklist Dataset https://doi.org/10.15468/39omei accessed via GBIF.org on 2018-01-18. At https://www.gbif.org/species/4307307.

Griffin, D. J. G. 1974. Spider crabs (Crustacea: Brachyura: Majidae) from the international Indian Ocean Expedition, 1963-1964. Smithsonian Contribution to Zoology, 182: i-iv, 1-35.

Griffin, D. J. G., and H. A. Tranter. 1986. The Decapoda Brachyura of the Siboga Expedition. Part 8, Majidae. Siboga Expedition, Monographie, 39: 1-335.

Guilcher, A., L. Berthois, Y. Le Calvez, R. Battistini, and A. Crosnier. 1965. Les récifs coralliens et le lagon de l'île de Mayotte (Archipel des Comores, Océan Indien), Géomorphologie, Sédimentologie, Hydrologie, Foraminifères. Office de la Recherche Scientifique et Technique Outre-mer (ORSTOM) édition, Paris: 1-210. À http://www.documentation.ird.fr/hor/fdi:10967.

Guinot-Dumortier, D. 1960. Les espèces Indo-pacifiques du genre Globopilumnus (Crustacea Brachyura Xanthidae). Mémoires de l'Institut Scientifique de Madagascar, série F, 1959 (1960), 3: 97-119. 
Guinot, D. 1957. Sur une collection de Décapodes Brachyoures (Portunidae et Xanthidae) de l'Ile Mayotte. I. Portunus (Hellenus) mariei sp. nov. Bulletin du Muséum National d'Histoire Naturelle, 29 (6): 475-484.

1958a. Sur une collection de Décapodes Brachyoures (Portunidae et Xanthidae) de l'Ile Mayotte.

II. Xanthidae. Bulletin du Muséum National d'Histoire Naturelle 30 (1): 84-93.

. 1958b. Sur une collection de Décapodes Brachyoures (Portunidae et Xanthidae) de l'Ile Mayotte.

II. Xanthidae (suite). Bulletin du Muséum National d'Histoire Naturelle 30 (2): 175-183.

1958c. Sur une collection de Décapodes Brachyoures (Portunidae et Xanthidae) de l'Ile Mayotte.

II. Xanthidae. Bulletin du Muséum National d'Histoire Naturelle 30 (3): 276-284.

. 1962a. Sur quelques crustacés décapodes brachyoures indo-pacifiques des collections du Musée de Munich. Opuscula Zoologica, 60: 1-14.

- 1962b. Sur une collection de Crustacés Décapodes Brachyoures de Mer Rouge et de Somalie. Bolletino del Museo Civico di Storia Naturale di Venezia, 15: 7-63.

— 1962c. Sur une collection de Crustacés Décapodes Brachyoures des îles Maldives et de la Mer Rouge (Expédition «Xarifa» 1957-1958). Kieler Meeresforschungen, Kiel, 18 (2): 231-244.

. 1964a. Les trois espèces du genre Domecia (Decapoda, Brachyura): D. hispida Eydoux and Souleyet, D. glabra Alcock et D. Acanthophora (Desbonne and Schramm). Crustaceana, 7 (4): $267-$ 283.

1964b. Crustacés décapodes brachyoures (Xanthidae) des campagnes de la Calypso en mer rouge (1952), dans le golfe persique, et à l'île Aldabra (1954). Mémoires du Muséum National d'Histoire Naturelle, 32 (1): i-iii, 1-108.

- 1966. Recherches préliminaires sur les groupements naturels chez les crustacés décapodes brachyoures. I. Les affinités des genres Aethra, Osachila, Hepatus, Hepatella et Actaeomorpha. Bulletin du Muséum national d'Histoire naturelle, 38 (5): 744-762.

- 1967a. Recherches préliminaires sur les groupements naturels chez les crustacés décapodes brachyoures. I. Les affinités des genres Aethra, Osachila, Hepatus, Hepatella et Actaeomorpha. Bulletin du Muséum national d'Histoire naturelle, 1966 (1967), 38 (6): 828-845.

— 1967b. La faune carcinologique de l'Océan Indien occidental et de la mer rouge. Catalogue, remarques biogéographiques, et bibliographie. Mémoires de l'Institut Français de l'Afrique noire, IFAN-Dakar, 1966 (1967), 77: 237-352.

-1967c. Recherches préliminaires sur les groupements naturels chez les crustacés décapodes brachyoures. II. Les anciens genres Micropanope Stimpson et Medaeus Dana. Bulletin du Muséum national d'Histoire naturelle, 39 (2): 345-374.

- 1976. Constitution de quelques groupes naturels chez les crustacés décapodes brachyoures. I, La superfamille des Bellioidea, et trois sous-familles de Xanthidae (Polydectinae Dana, Trichiinae de Haan, Actaeinae Alcock). Mémoires du Muséum National d'Histoire Naturelle, 97: 1-308.

—. 1979. Morphologie et phyllogénèse des Brachyoures. Données nouvelles sur la morphologie, la phylogenèse et la taxonomie des crustacés décapodes brachyoures. Mémoires du Muséum national d'Histoire naturelle, 112: 1-354.

-1990. Crustacea Decapoda : le genre Psopheticus Wood-Mason, 1892 (Goneplacidae). In, Crosnier A. (Ed.), Résultats des campagnes MUSORSTOM, volume 6. Mémoires du Muséum national d'Histoire naturelle, 145: 331-367.

Guinot, D., and E. Macpherson. 1988. - Remarques sur le genre Monodaeus Guinot, 1967, avec la description de deux espèces nouvelles (Crustacea, Decapoda, Brachyura). Bulletin du Muséum national d'Histoire naturelle, 10 (4): 731-757.

Guinot, D., and B. Richer de Forges. 1995. Crustacea Decapoda Brachyura: Révision de la famille des Homolidae de Haan, 1839. In, Crosnier A. (Ed.), Résultats des campagnes MUSORSTOM, volume 13. Mémoires du Muséum national d'Histoire naturelle, 163: 283-517.

Guinot, D., and M. Tavares. 2003. A new subfamilial arrangement for the Dromiidae de Haan, 1833, with diagnoses and descriptions of new genera and species (Crustacea, Decapoda, Brachyura).

Zoosystema, 25 (1): 43-129. 
Guinot, D., M. Tavares, and P. Castro. 2013. Significance of the sexual openings and supplementary structures on the phylogeny of brachyuran crabs (Crustacea, Decapoda, Brachyura), with new nomina for higher-ranked podotreme taxa. Zootaxa, 3665 (1): 1-414.

Hoffmann, C. K. 1874. Crustacés et échinodermes de Madagascar et de l'île de la Réunion. In Pollen F. P. L. and Van Dam D. C., Recherches sur la Faune de Madagascar et de ses dépendances, d'après les découvertes de François P. L. Pollen et D. C. Van Dam, ouvrage dédié à S. M. Guillaume III, roi des Pays-Bas, 5ème partie. Leiden, E. J. Brill: 1-58.

Holthuis, L. B. 1977. The Grapsidae, Gecarcinidae and Palicidae (Crustacea: Decapoda: Brachyura) of the Red Sea. Israel Journal of Zoology, 26: 141-192.

Kawamoto, T., and J. Okuno. 2003. Shrimps and crabs of Kume Island, Okinawa. Hankyu Communications Co, Ltd, Tokyo: 1-173.

Kazmi, Q. B. 1997. A review of spider majid crabs of the northern Arabian Sea, with particular reference to Pakistani species, and with description of an undescribed Pleistacantha. Pakistan Journal of Marine Sciences, 6 (1-2): 79-91.

Keith, P., G. Marquet, P. Valade, P. Bosc, and P. Vigneux. 2006. Atlas des poissons et des crustacés d'eau douce des Comores, Mascareignes et Seychelles. Muséum national d'Histoire naturelle, Paris, collection Patrimoines Naturels, 65: 1-250.

Koh, S. K., and P. K. L. Ng. 2008. A revision of the shore crabs of the genus Eriphia (Crustacea: Brachyura: Eriphiidae). Raffles Bulletin of Zoology, 56 (2): 327-355.

Komai, T., and P. K. L. Ng. 2012. A new genus and new species of leucosiid crab (Crustacea: Decapoda: Brachyura) from coral reefs in the Indo-West Pacific. Zootaxa, 3352: 40-50.

Komai, T., and J. Poupin. 2012. Two new species of shallow-water hermit crabs (Crustacea: Decapoda: Paguridae) from Mayotte Island, southwestern Indian Ocean. Zootaxa, 3277: 56-68.

Komai, T., and J. Poupin. 2013. Records of the hermit crab genus Pagurixus Melin, 1939 (Crustacea: Decapoda: Anomura: Paguridae) from Europa Island, western Indian Ocean, with descriptions of two new species. Zootaxa, 3608 (3): 191-203.

Komatsu, H., and P. K. L. Ng. 2011. Kabutos, a new genus for the western Pacific leucosiid crab, Merocryptus durandi Serène, 1955 (Crustacea: Decapoda: Brachyura). Zootaxa, 2881: 31-38.

Lee, S. -K., J. -C., Mendoza, P. K. L. Ng, and W. Kim. 2013. On the identity of the Indo-West Pacific littoral xanthid crab, Leptodius exaratus (H. Milne Edwards, 1834) (Crustacea: Decapoda: Brachyura: Xanthidae). The Raffles Bulletin of Zoology, 61 (1): 189-204.

Legall, N., and J. Poupin. 2018 CRUSTA: Database of Crustacea (Decapoda and Stomatopoda. At http://crustiesfroverseas.free.fr/. Consulted January 2018.

Lenz, H. 1910. Crustaceen von Madagaskar, Ostafrika und Ceylon. In A. Voeltzkow (Ed.), Reise in Ostafrika in den Jahren 1903-1905 mit Mitteln der Hermann und Elise geb. Heckmann WentzelStiftung ausgeführt. Wissenschaftliche Ergebnisse, Systematische Arbeiten, 2: 539-576.

Leray, M. 2012. Le rôle des interactions biotiques sur la structure des communautés de décapodes associés aux coraux. Thèse de Doctorat de l'Université Pierre et Marie Curie, Spécialité Biodiversité, Ecologie, Environnement. Ecole Doctorale 129 - Sciences de l'Environnement d'Ile de France. Thèse soutenue le 28 mai 2012: 1-246.

Lewinsohn, C. 1984. Dromiidae (Crustacea, Decapoda, Brachyura) from Madagascar and the Seychelles. Bulletin du Muséum national d'Histoire naturelle, 6(1): 89-129.

Li, X., R. Cleva, and J. Poupin. 2012. Report on some caridean shrimps (Crustacea: Decapoda) from Mayotte, southwest Indian Ocean. Zootaxa, 3162: 1-30.

Losse, G. F. 1969. - Notes on the portunid crab Charybdis edwardsi Leene and Buitendijk, 1949, from the Western Indian Ocean. Journal of Natural History, 3: 145-152.

Macpherson, E., and R. Cleva. 2010. Shallow-water squat lobsters (Crustacea, Decapoda, Galatheidae) from Mayotte (Comoros Island), La Réunion and Madagascar, with the description of a new genus and two new species. Zootaxa, 2612: 57-68. At http://decapoda.nhm.org/pdfs/31573/31573.pdf

Man, J. G. de. 1888. Bericht über die im indischen Archipel von Dr. J. Brock gesammelten, Dekapoden und Stomatopoden. Archiv für Naturgeschichte, 53: 215-600. 
Manning, R. B. 1993. West African pinnotherid crabs, subfamily Pinnotherinae (Crustacea, Decapoda, Brachyura). Bulletin du Muséum national d'Histoire naturelle, 15(1-4): 125-177.

Milne-Edwards, A. 1872. Recherches sur la faune carcinologique de la Nouvelle-Calédonie. Nouvelles Archives du Muséum, 8: 229-267.

McLay, C. L. 1993. Crustacea Decapoda: The sponge crabs (Dromiidae) of New Caledonia and the Philippines with a review of the genera. In, A. Crosnier (ed.), Résultats des campagnes MUSORSTOM, volume 10. Mémoires du Muséum national d'Histoire naturelle, 156: 111-251.

- 1999. Crustacea Decapoda: Revision of the family Dynomenidae. In, A. Crosnier (Ed.), Résultats des campagnes MUSORSTOM, volume 20. Mémoires du Muséum national d'Histoire naturelle, 180: 427-569.

- 2001. Dynomenidae and Dromiidae (Decapoda, Brachyura) from Guam, Philippines Islands, Tonga and Samoa. Zoosystema, 23 (4): 807-856.

Mendoza, J. C. E. 2013. A new species of ocellated Xanthias Rathbun, 1897 (Crustacea: Decapoda: Brachyura: Xanthidae) from the Bohol Sea, Philippines. Zootaxa, 3636 (2): 374-384.

Mendoza, J. C. E., and S. S. Devi 2017. A new species of the swimming crab genus, Laleonectes Manning \& Chace, 1990 (Crustacea: Brachyura: Portunidae), from the western Indian Ocean. Zootaxa, 4323 (2): 219-228.

Mendoza, J. C. E., and P. K. L. Ng. 2010. The Euxanthinae crabs (Crustacea: Brachyura: Xanthidae) of the Philippines. The Raffles Bulletin of Zoology, 58 (1): 57-74.

Mendoza, J. C. E., P. F. Clark, and P. K. L. Ng. 2012. The identity of Pilumnoplax acanthomerus Rathbun, 1911 (Crustacea: Decapoda: Brachyura: Xanthidae), with new records from the central and western Pacific. In Naruse, T., Chan, T. -Y., Tan, H. H., Ahyong, S. T. and Reimer, J. D. (Eds), Scientific Results of the Marine Biodiversity Expedition KUMEJIMA 2009. Zootaxa, 3367: 211-221.

Mendoza, J. C. E., R. M. Lasley, and P. K. L. Ng. 2014. New rock crab records (Crustacea: Brachyura: Xanthidae) from Christmas and Cocos (Keeling) Islands, Eastern Indian Ocean. Raffles Bulletin of Zoology, Supplement, 30: 274-300.

Miers, E. J. 1884. Crustacea. Report on the Zoological collection made in the Indo-Pacific Ocean during the voyage of H.M.S. Alert, 1881-1882. British Museum, London. Part I, The collections from Melanesia: 178-322; part II, The collections from the Western Indian Ocean: 513-575.

Milne-Edwards, A. 1868. Description de quelques Crustacés nouveaux provenant des voyages de M. Alfred Grandidier à Zanzibar et à Madagascar. Nouvelles Archives du Muséum d'Histoire naturelle, 4: 69-92.

Milne-Edwards, A. 1872. Recherches sur la faune carcinologique de la Nouvelle-Calédonie. Nouvelles Archives du Muséum d'Histoire naturelle, 8: 229-267.

Milne-Edwards, A. 1873. Recherches sur la faune carcinologique de la Nouvelle-Calédonie. Nouvelles Archives du Muséum d'Histoire naturelle, 9: 155-332.

Milne Edwards, H. 1853. Mémoire sur la famille des Ocypodiens. Annales des Sciences Naturelles, Zoologie, Paris, 3ème série, 20: 163-228.

MNHN-Collection 2018. Crustacés (IU), Expedition KUW MAYOTTE 2009, Order Decapoda. Invertebrate collections of the Muséum national d'Histoire naturelle, MNHN, Paris, France. at https://science.mnhn.fr/institution/mnhn/collection/iu/item/list?expedition=KUW+MAYOTTE+2009 \&order=Decapoda\&lang=en_US. Consulted January 2018.

Naderloo, R. 2011. Grapsoid crabs (Decapoda: Brachyura: Thoracotremata) of the Persian Gulf and the Gulf of Oman. Zootaxa, 3048: 1-43.

- 2013. The sentinel crabs of the genus Chaenostoma (Stimpson, 1858) (Crustacea: Brachyura: Macrophthalmidae), with description of a new species and new records. Journal of Natural History, 47 (45-46): 2835-2848.

Naderloo, R., and M. Apel. 2012. Leucosiid crabs of the genus Hiplyra Galil, 2009 (Crustacea: Brachyura: Leucosiidae) from the Persian Gulf and Gulf of Oman, with description of a new species. Zoological Studies, 51 (2): 248-258. 
Naderloo, R., and M. Türkay. 2010. A new species of the Macrophthalmus boscii-group (Decapoda: Brachyura: Macrophthalmidae) from the Persian Gulf with designation of a Neotype for M. boscii Audouin (1826). Marine Biodiversity, 41: 503-515.

Naderloo, R., M. Türkay, and H. -L. Chen. 2010. Taxonomic revision of the wide-front fiddler crabs of the Uca lactea group (Crustacea: Decapoda: Brachyura: Ocypodidae) in the Indo-West Pacific. Zootaxa, 2500: 1-38.

Nagai, S., and K. Nomura. 1988. The guide book of the marine animals and plants of Okinawa. Volume 7, Crustacea Brachyura. Southern Press, Okinawa, Japan: 1-250 (in Japanese).

Naruse, T. 2013. Species of Corycodus A. Milne-Edwards, 1880 (Crustacea, Brachyura, Cyclodorippidae) collected from the Mozambique MAINBAZA and Madagascar MIRIKY expeditions, with description of a new species. In, Ahyong S. T., Chan T. Y., Corbari L. and Ng P. K. L. (Eds), Tropical Deep-Sea Benthos volume 27. Mémoires du Muséum national d'Histoire naturelle, 204: 485-494.

Ng, P. K. L. 1987. The Indo-Pacific Pilumnidae II. A revision of the genus Rhizopa Stimpson, 1858 and the status of the Rhizopinae Stimpson, 1858 (Crustacea, Decapoda, Brachyura). Indo-Malayan Zoology, 4: 69-111.

1993. Kraussiinae, a new subfamily for the genera Kraussia Dana, 1852, Palapedia, new genus, and Garthasia, new genus (Crustacea: Decapoda: Brachyura: Xanthidae), with descriptions of two new species from Singapore and the Philippines. Raffles Bulletin of Zoology, 41 (1): 133-157.

- 1999. A synopsis of the genus Aethra Latreille, 1816 (Decapoda, Brachyura, Parthenopidae). Crustaceana, 72 (1): 109-121.

- 2002. - The Indo-Pacific Pilumnidae XVI. On the identity of Pilumnus cristimanus A. Milne Edwards, 1873 and the status of Parapilumnus Kossman, 1877 (Crustacea: Decapoda: Brachyura), with description of a new species from rubble beds in Guam. Micronesica, 34 (2): 209-226.

- 2010. On the Planopilumnidae Serène, 1984 (Crustacea: Brachyura: Pseudozioidea), with diagnoses of two new pilumnoid genera for species previously assigned to Planopilumnus Balss, 1933. Zootaxa, 2392: 33-61.

Ng, P. K. L., and C. B. Boyko. 2017. New Species and Records of Crabs of the Families Dromiidae, Dynomenidae, Homolidae, Aethridae, Parthenopidae, Majidae, and Epialtidae (Crustacea: Decapoda: Brachyura) from Easter Island, with a Review of the Majid Genus Schizophroida Sakai, 1933. Pacific Science, 71 (2): 197-227.

Ng, P. K. L., and G. B. Chia. 1997. Lophozozymus erinnyes, a new species of poisonous crab from Australia, with notes on L. pictor (Fabricius, 1798), L. incisus (H. Milne Edwards, 1834) and L. edwardsi (Odhner, 1925) (Crustacea: Decapoda: Brachyura: Xanthidae). The Raffles Bulletin of Zoology, 45 (2): 419-443.

Ng, P. K. L., and P. F. Clark. 2002. Description of a new species of Paramedaeus Guinot, 1967, with notes on Paramedaeus simplex (A. Milne-Edwards, 1873) and Metaxanthops acutus Serène, 1984 (Decapoda, Brachyura, Xanthoidea, Xanthidae). Crustaceana, 75 (2-3): 527-538.

- 2008. A revision of Latopilumnus Türkay and Schuhmacher, 1985 and Aniptumnus Ng, 2002 (Crustacea: Decapoda: Brachyura: Pilumnidae) with larval comparisons. Journal of Natural History, 42 (9-12): 885-912.

Ng, P. K. L., and Q. B. Kazmi. 2011. Planopilumnus holthuisi, a new species of planopilumnid crab (Decapoda, Brachyura, Pseudozioidea) from Pakistan. Studies on Malacostraca: Lipke Bijdeley Holthuis Memorial Volume. Crustaceana Monographs, 14: 585-596.

Ng, P. K. L., and C. L. McLay. 2003. - On the systematic position of Lambrachaeus Alcock, 1895 (Brachyura, Parthenopidae). Crustaceana, 76 (8): 897-915.

Ng, P. K. L., and T. Naruse. 2009. On the identity of Pinnixa brevipes H. Milne Edwards, 1853, and a new species of Aphanodactylus Tesch, 1918 (Crustacea: Decapoda: Brachyura: Pinnotheroidea) from the Philippines. Raffles Bulletin of Zoology, supplements 20: 283-290.

Ng, P. K. L., and D. L. Rahayu. 2016. On the genera Selwynia Borradaile, 1903, and Gandoa Kammerer, 2006, with descriptions of two new species from Papua New Guinea and French Polynesia (Crustacea: Decapoda: Brachyura: Aphanodactylidae). Zootaxa, 4092 (3): 339-370. 
Ng, P. K. L., and B. Richer de Forges. 2007. The Brachyura of New Caledonia. In, Payri C.E. and Richer de Forges B. (Eds) Compendium of marine species of New Caledonia. Documentation Scientifique et Technique du centre IRD Nouméa II (7): 315-331. At http://www.documentation.ird.fr/hor/fdi:010038894

. 2015. Revision of the spider crab genus Maja Lamarck, 1801 (Crustacea: Brachyura: Majoidea: Majidae), with descriptions of seven new genera and 17 new species from the Atlantic and Indo-West Pacific. Raffles Bulletin of Zoology, 63: 110-125.

Ng, P. K. L., P. J. F. Davie, and D. Guinot. 2008. Systema Brachyurorum: Part 1. An Annotated checklist of extant Brachyuran crabs of the world. The Raffles Bulletin of Zoology, supplement series 17: 1286. At https://decapoda.nhm.org/references/referenceinfo.html?refid=27562

Ng, P. K. L., C. H. Wang, P. H. Ho, and H. T. Shih. 2001. An annotated checklist of the brachyuran crabs from Taiwan (Crustacea: Decapoda). National Taiwan Museum Special Publication Series, 11: 1-86.

Nobili, G. 1905. Quatre décapodes nouveaux de Golfe Persique (récoltes de MM. J. Bonnier et Ch. Pérez). Bulletin du Muséum d'Histoire naturelle Paris, 11: 238-239.

Odhner, T. 1925. Monographierte Gattungen der Krabbenfamilie Xanthidae. I. Göteborgs Kungliga Vetenskaps - och Vitterhets-Samhälles Handlingar, 29 (1): 1-92.

Osawa, M., and N. -K. Ng. 2006. A new species of Ptychognathus Stimpson, 1858 (Crustacea: Decapoda: Brachyura: Varunidae) from the Ryukyu Islands, southwestern Japan. Zootaxa, 1260: 57-66.

Osawa, M., and J. Poupin. 2013. First record of the porcellanid crab, Polyonyx boucheti (Crustacea: Decapoda: Anomura) from the Indian Ocean. Marine Biodiversity Records, 6: 1-5.

Paulay, G., R. Kropp, P. K. L. Ng, and L. G. Eldredge. 2003. The crustaceans and pycnogonids of the Mariana Islands. Micronesica, 35-36: 456-513.

Peyrot-Clausade, M. 1989. Crab cryptofauna (Brachyura and Anomura) of Tikehau, Tuamotu Archipelago, French Polynesia. Coral Reefs, 8: 109-117.

Peyrot-Clausade, M., and R. Serène. 1976. Observations sur quelques espèces de Brachyoures (Crustacés Décapodes) de Madagascar. Bulletin du Muséum national d'Histoire naturelle, 416: 1339-1371.

Pollen, F. P. L. 1868. Relation de Voyage. In, Pollen F. P. L. and D. C. Van Dam, Recherches sur la faune de Madagascar et de ses dépendances, d'après les découvertes de François P. L. Pollen et D. C. Van Dam, ouvrage dédié à S. M. Guillaume III, Roi des Pays-Bas, 1ère Partie. J. K. Steenhoff Ed., Leyde: $1-240$.

Poupin, J. 2005. Systématique et écologie des crustacés décapodes et stomatopodes de Polynésie française. Mémoire d'Habilitation à Diriger des Recherches, Université de Perpignan: 1-115. À https://tel.archives-ouvertes.fr/tel-00085049/

. 2009. Crustacés de la Réunion, Décapodes et Stomatopodes. IRD Editions, Marseille: 1-140. À http://www.editions.ird.fr/produit/88/9782709916769/

. 2010. Biodiversité de 1'Indo-Pacifique tropical français : 2514 espèces de crustacés décapodes et stomatopodes. Rapport Scientifique de l'Institut de Recherche de l'Ecole Navale, Octobre 2010: 1-76. À https://hal.archives-ouvertes.fr/hal-01559225v1 (with Excel file).

. Deep water Decapoda collected during the BENTHEDI Expedition in Mayotte region (17/03 to 15/04/1977, R/V Suroît). SEANOE, Sea scientific open data edition 2015-12: 1-10. Available at http://www.seanoe.org/data/00298/40956/. Consulted January 2018.

- First inventory of the Crustacea (Decapoda, Stomatopoda) of Juan de Nova Island with ecological observations and comparison with nearby islands in the Mozambique Channel (Europa, Glorieuses, Mayotte). Acta Oecologica 72: 41-52.

Poupin, J., and J. -M. Bouchard 2010. A new dwarf sentinel crab from Mayotte Island, western Indian Ocean (Decapoda: Brachyura: Macrophthalmidae). Zootaxa, 2501: 61-67.

Poupin, J., J. -M. Bouchard, R. Cleva, J. Dumas, and V. Dinhut. 2012. Base de données Internet pour l'inventaire des crustacés de la région de Mayotte. À http://crustaceamayotte.free.fr/. Consulté Janvier 2018 (non mise à jour depuis novembre 2012).

Poupin, J., J. -M. Bouchard, V. Dinhut, R. Cleva, and J. Dumas. 2013a. Anomura of Mayotte region (Crustacea Decapoda). Atoll Research Bulletin, 593: 1-73. At http://opensi.si.edu/index.php/smithsonian/catalog/book/35 
Poupin, J., M. Zubia, N. Gravier-Bonnet, P. Chabanet, and M. Malay. 2013b. Illustrated Checklist of the Decapoda at Europa Island. Western Indian Ocean Journal of Marine Science, 11 (1): 1-25.

Poupin, J., M. Zubia, N. Gravier-Bonnet, P. Chabanet, and A. Duhec. 2013c. Crustacea Decapoda of Glorieuses Islands, with notes on the distribution of the coconut crab (Birgus latro) in the western Indian Ocean. Marine Biodiversity Records: 1-12.

Poupin, J., J.-P. Quod, M. Zubia, S. Bollard, A. Barrère, and H. Magalon. 2013d. Les crustacés de La Réunion (Crustacea, Decapoda) dans la zone marine du Piton de la Fournaise. Rapport scientifique de l'Institut de Recherche de l'Ecole Navale, 2013: 1-10. À https://hal.archives-ouvertes.fr/hal$\underline{01069920 /}$

Ragionieri, L., S. Fratini, M. Vannini, and C. D. Schubart. 2009. Phylogenetic and morphometric differentiation reveal geographic radiation and pseudo-cryptic speciation in a mangrove crab from the Indo-West Pacific. Molecular Phylogenetics and Evolution, 52: 825-834.

Ragionieri, L., S. Cannicci, C. D. Schubart, and S. Fratini. 2010. Gene flow and demographic history of the mangrove crab Neosarmatium meinerti: A case study from the western Indian Ocean. Estuarine, Coastal and Shelf Science, 86: 179-188.

Ragionieri, L., S. Fratini, and C. D. Schubart. 2012. Revision of the Neosarmatium meinerti species complex (Decapoda: Brachyura: Sesarmidae), with descriptions of three pseudocryptic Indo-West Pacific species. The Raffles Bulletin of Zoology, 60 (1): 71-87.

Rahayu, D. L., and P. K. L. Ng. 2009. Two new species of Parasesarma De Man, 1895, from Southeast Asia (Crustacea: Decapoda: Brachyura: Sesarmidae). Zootaxa, 1980: 29-40.

Rathbun, M. J. 1906. The Brachyura and Macrura of the Hawaiian Islands. Bulletin of the United States Fish Commission, 23 (3): 827-930.

- 1911. Marine Brachyura. In, The Percy Sladen Trust expedition to the Indian Ocean in 1905 under the leadership of Mr. J. Stanley Gardiner. Vol. III, $\mathrm{n}^{\circ}$ XI. Transactions of the Linnean Society of London, series 2, Zoology, 14 (2): 191-261.

Rosenberg, M. S. 2013. The nomenclatural status of the two "spiny-wristed" fiddler crabs: Uca spinicarpa Rathbun, 1900, and U. hesperiae Crane, 1975 (Crustacea: Brachyura: Ocypodidae). Zootaxa, 3716 (3): 494-500.

- 2014. Contextual Cross-Referencing of Species Names for Fiddler Crabs (Genus Uca): An Experiment in Cyber-Taxonomy. PLoS ONE 9 (7): e101704.

. 2018. - Fiddler Crabs: Uca hesperiae at http://www.fiddlercrab.info/u hesperiae.html. Consulted 2018.

Sakai, K. 1999. J.F.W. Herbst-collections of Decapoda Crustacea of the Berlin Zoological Museum, with remarks on certain species. Naturalists publications of the Tokushima Biological Laboratory, Shikoku University, 6: 1-45.

- 2004. Crabs of Japan. CD - ETI, University of Amsterdam: ISBN 90-75000-59-6. Available at Marine Species Identification Portal (ETI BioInformatics). http://speciesidentification.org/search.php. Consulted January 2018.

Salvat, B., and P. Bacchet. 2011. Guide des récifs coralliens de Tahiti et ses îles. Au Vent des Iles, Tahiti: $1-365$.

Schmitt, W. L., J. C. McCain, and E. S. Davidson. 1973. Decapoda I, Brachyura I, Fam. Pinnotheridae. In Gruner, H. E., and L. B. Holthuis (Eds). Crustaceorum Catalogus, 3: 1-160.

Serène, R. 1964. Goneplacidae et Pinnotheridae. Papers from Dr. Th. Mortensen's 1914-1916 Pacific Expedition, 80: 181-282.

- 1968. The Brachyura of the Indo-West Pacific Region. UNESCO regional center for science and technology for southeast Asia. Prodromus for a Check List of the (non-planctonic) Marine Fauna of South East Asia. Fourth Regional Meeting of Marine Science Experts in East and Southeast Asia, Singapore, 18-21 March, 1968: 33-112 (mimeographed).

- 1972. - Observations on the Indo-pacific species of Kraussia Dana 1852 (Decapoda: Brachyura). Journal of the Royal Society of Western Australia, 55 (2): 41-61.

- 1977. Crustacés Hippidés et Brachyoures des îles Seychelles (1ère partie). Revue de Zoologie Africaine, 91 (1): 45-68. 
1984. Crustacés décapodes brachyoures de l'océan Indien Occidental et de la mer Rouge. Xanthoidea : Xanthidae et Trapeziidae. ORSTOM Collection Faune Tropicale, 24: 1-349.

Serène, R. and V. L. Nguyen. 1960. Les espèces de Carpilodes (Brachyura, Xanthidae) du Viêt-Nam. Annales de la Faculté des Sciences, Saigon: 173-185.

Shih, H. -T., T. Naruse, and P. K. L. Ng. 2010. Uca jocelynae sp. nov., a new species of fiddler crab (Crustacea: Brachyura: Ocypodidae) from the Western Pacific. Zootaxa, 2337: 43-62.

Shih, H. -T., P. K. L. Ng, K. J. H. Wong, and B. K. K. Chan. 2012. Gelasimus splendidus Stimpson, 1858 (Crustacea: Brachyura: Ocypodidae), a valid species of fiddler crab from the northern South China Sea and Taiwan Strait. Zootaxa, 3490: 30-47.

Shih, H. -T., P. K. L. Ng, and M. Y. Liu 2013. Systematics of the Indo-West Pacific broad-fronted fiddler crabs (Crustacea: Ocypodidae, Genus Uca). The Raffles Bulletin of Zoology, 61: 641-649.

Shih, H. -T., B. K. K. Chan, S. -J. Teng, and K. J. H. Wong 2015. Crustacean Fauna of Taiwan: Brachyuran Crabs, Volume II Ocypodoidea. National Chung Hsing University, Taichung, Taiwan: 1320.

Shih, H. -T., P. K. L. Ng, P. J. F. Davie, C. D. Schubart, M. Türkay, R. Naderloo, D. Jones, and M. -Y. Liu. 2016. Systematics of the family Ocypodidae Rafinesque, 1815 (Crustacea: Brachyura), based on phylogenetic relationships, with a reorganization of subfamily rankings and a review of the taxonomic status of Uca Leach, 1814, sensu lato and its subgenera. Raffles Bulletin of Zoology, 64: $139-175$.

Shih H. -T, B. K. K. Chan, and P. K. L. Ng 2018. Tubuca alcocki, a new pseudocryptic species of fiddler crab from the Indian Ocean, sister to the southeastern African T. urvillei (H. Milne Edwards, 1852) (Crustacea, Decapoda, Brachyura, Ocypodidae). ZooKeys, 747: 41-62. At https://doi.org/10.3897/zookeys.747.23468.

Spiridonov, V. A. 2017a. Xiphonectes tuerkayi sp. n. from the Indian Ocean with notes on Xiphonectes longispinosus Dana, 1852 (Crustacea: Decapoda: Portunidae). Arthropoda Selecta, 25 (4): 357-372.

-2017b. Two new species of Thalamita Latreille, 1829 (Decapoda, Portunidae). Crustaceana, 90 (7-10): 1211-1233.

Števčić, Z. 2005. The reclassification of Brachyuran crabs (Crustacea: Decapoda: Brachyura). Natura Croatica, 14, Supplement 1: 1-159.

Takeda, M. 1971. New and rare crabs from the Palau Islands. Micronesica, 7 (1/2): 185-213.

Takeda, M. and S. Miyake. 1968. Pilumnid crabs of the family Xanthidae from the West Pacific. I. Twenty-three species of the genus Pilumnus, with description of four new species. OHMU Occasional papers of Zoological Laboratory Faculty of Agriculture, Kyushu University, 1(1): 1-58.

Takeda, M., K. Okamoto, and T. Fukuda. 1976. Huenia brevifrons Ward (Decapoda, Majidae) attached to calcareous green alga, Halimeda, from the Ryukyu Islands. Bulletin of the National Science Museum, Tokyo, 2 (2): 103-108.

Tan, C. G. S., and P. K. L. Ng, 1995. A revision of the Indo-Pacific genus Oreophorus Rüppell, 1830 (Crustacea: Decapoda: Brachyura: Leucosiidae). In, Richer de Forges B. (Ed.), Les fonds meubles des lagons de Nouvelle-Calédonie (Sédimentologie, benthos). Etudes and Thèses, ORSTOM/IRD, Volume 2: $101-189$.

Tan, S. H., and P. K. L. Ng. 2007. Review of the subfamily Daldorfiinae Ng and Rodriguez, 1986 (Crustacea: Decapoda: Brachyura: Parthenopidae). The Raffles Bulletin of Zoology, 16: 121-167.

Teng, S. -J., H. -T. Shih, R. Naderloo, and L. Corbari. 2016. A review of the Chaenostoma boscii speciescomplex (Decapoda: Brachyura: Macrophthalmidae) from the Indo-West Pacific. Crustacean Research, 45: 15-27.

Tesch, J. J. 1918. The Decapoda Brachyura of the Siboga Expedition. II: Goneplacidae and Pinnotheridae. Siboga Expéditie, 39(C1):149-296.

Thoma, B. P., D. Guinot, and D. L. Felder. 2014. Evolutionary relationships among American mud crabs (Crustacea: Decapoda: Brachyura: Xanthoidea inferred from nuclear and mitochondrial markers, with comments on adult morphology. Zoological Journal of the Linnean Society, 2013 (2014), 170 (1):86109. 
Vannini, M., and G. Innocenti. 2000. Research on the coast of Somalia. Portunidae (Crustacea Brachyura). Tropical Zoology, 13: 251-298.

Vannini, M., and P. Valmori. 1981. Researches on the coast of Somalia. The shore and the dune of Sar Uanle. 30. Grapsidae (Decapoda, Brachyura). Monitore zoologico italiano, 14 (6): 57-101.

WoRMS 2018. World Register of Marine Species. At http://www.marinespecies.org at VLIZ. Consulted January 2018.

Zaouali, J., J. Ben Souissi, B. S. Galil, C. d'Udekem d'Acoz, and A. Ben Abdallah. 2007. Grapsoid crabs (Crustacea: Decapoda: Brachyura) new to the Sirte Basin, southern Mediterranean Sea: the roles of vessel traffic and climate change. JMBA2. Biodiversity Records: 1-5. 


\section{APPENDIX: LIST OF CRABS IN MAYOTTE REGION}

In addition to the 202 crabs of Mayotte KUW 2009 expedition 90 records of crabs in Mayotte region have been retrieved in the scientific literature and six more species have been recognized with confidence (J. Poupin) on photographs, the specimens being not collected. These latter are common species having large IWP distribution: Calappa calappa (photo Y. Gildas), Camposcia retusa (photo M. Deuss), Daira perlata (photo N. Verneau), Macrophthalmus milloti (photos L. Bigot), Ozius guttatus (photos N. Verneau), Plagusia immaculata (photos N. Verneau), and Portunus sanguinolentus (photos J. -B. Nicet, N. Verneau). Their photographs can be consulted in Legall and Poupin (2018) with some of them presented in this work.

To simplify the formatting the list is presented alphabetically by name of species without the supraspecific classification that can be retrieved from WoRMS (2018). The following families are added to Mayotte KUW 2009 inventory: Aphanodactylidae Ahyong and Ng, 2009; Crossotonotidae Moosa and Serène, 1981; Cyclodorippidae Ortmann, 1892; Dairidae Ng and Rodríguez, 1986; Ethusidae Guinot, 1977; Euryplacidae Stimpson, 1871; Goneplacidae MacLeay, 1838; Homolidae De Haan, 1839; Latreilliidae Stimpson, 1858; and Palicidae Bouvier, 1898.

To serve as an index of scientific names for Mayotte region the species that were sampled in Mayotte KUW 2009 expedition are listed again. The species added are in bold and documented with literature consulted, geographic and depth ranges, and remarks (were necessary).

Actaea polyacantha (Heller, 1861) - Guinot, 1958a: 87, Mayotte, $196 \times 4$ mm, MNHN. - Guinot, 1967b: 260, list with Mayotte. - Serène, 1984: 114, Glorieuses, intertidal, coll. A. Crosnier 16 September 1958, 1 q $6 \times 9$ mm, MNHN-B 6551 — IWP, Red Sea, South Africa to Samoa, Kiribati; intertidal ?shallow subtidal.

Actaea spinosissima Borradaile, 1902

Actaeodes hirsutissimus (Rüppell, 1830) - Serène, 1984: 135, Mayotte, intertidal, coll. A. Crosnier

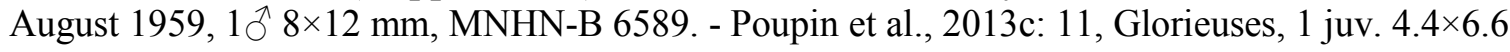
mm, MNHN-IU-2013-7359 — IWP, Kenya, Tanzania, Mozambique to Guam, French Polynesia; intertidal, subtidal.

Actaeodes tomentosus (H. Milne Edwards, 1834)

Aethra edentata Edmondson, 1951

Aethra scruposa (Linnaeus, 1764)

Alcomaja miriky Ng and Richer de Forges, 2015: 152, Leven Bank, between Glorieuses and Madagascar, MIRIKY, $1 \delta^{\Uparrow}$ holotype $26.4 \times 20.9 \mathrm{~mm}$, MNHN-IU-2010-929, st. DW 3215, 30 June 2009, 12³2'S 4754'E, 314-433 m - IWP, Mozambique Channel to Japan; 230-600m.

Ashtoret lunaris (Forskål, 1775) - Ashtoret lunaris - Poupin et al., 2013b: 11, Glorieuses - IWP, Red Sea, South Africa to Japan, New Caledonia; shallow subtidal.

Atergatis floridus (Linnaeus, 1767)

Atergatopsis signata (Adams and White, 1849) - Serène, 1984: 142, Glorieuses, Island du Lys, intertidal, coll. A. Crosnier 29 January 1971, 1 carapace $69 \times 101 \mathrm{~mm}$ - IWP, Red Sea, South Africa to Guam, French Polynesia; intertidal, subtidal.

Austruca annulipes (H. Milne Edwards, 1837)

Banareia armata A. Milne-Edwards, 1869 - Serène, 1984: 43, Mayotte, coll. A. Crosnier September

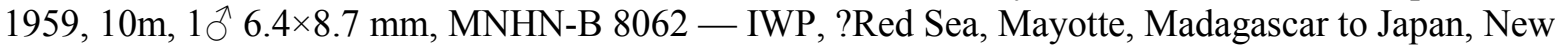
Caledonia; intertidal to $10 \mathrm{~m}$.

Banareia parvula (Krauss, 1843)

Bruciana pediger (Alcock, 1898)

?Caecopilumnus piroculatus (Rathbun, 1911) 
Calappa calappa (Linnaeus, 1758) - A common species first reported herein for Mayotte from a photo of a carapace, with very distinctive shape (photo Yvon Gildas, at http://img.over-blog.com/630x470000000/1/92/85/77//Crustac-s-2/2009-09-12-carapace-crabe-calappa.jpg) - IWP, Kenya, Mayotte (present study) to Hawaii, French Polynesia; 1-80m.

Calappa gallus (Herbst, 1803)

Calappa hepatica (Linnaeus, 1758)

Calappa woodmasoni Alcock, 1896 - Calappa depressa - Galil, 1997: 288, Mayotte lagoon, 50m,

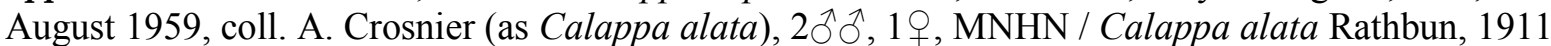
and Calappa depressa Miers, 1886 accepted as C. woodmasoni in WoRMS (2018) - IWP, Somalia, Mayotte to New Caledonia; 2-350m.

Camposcia retusa (Latreille, 1829) - A common species reported herein from photos in Mayotte lagoon (photo Matthias Deuss) - IWP, Red Sea, Mayotte (present study), South Africa to Japan, French Polynesia, 1-220m.

Carcinoplax longimana (De Haan, 1833) - Castro, 2012: 93, Leven Bank, south of Glorieuses, MIRIKY 2009, st. DW3183, 12³8'S, 48¹4'E, 420-436m, 26 June 2009, MNHN-IU-2010-947 IWP, Madagascar (Leven Bank) to Taiwan, Philippines; 63-436m.

Cardisoma carnifex (Herbst, 1796)

Carpilius convexus (Forskål, 1775)

Carupa tenuipes Dana, 1852 - Crosnier, 1962: 19, Mayotte. - Guinot, 1967b: 253, list with Mayotte IWP, Red Sea, South Africa to Hawaii, Pitcairn; invasive in Mediterranean (Galil et al., 2018); 1$100 \mathrm{~m}$.

Catoptrus rathbunae Serène, 1966

Chaenostoma crassimanus Stimpson, 1858

Chaenostoma lisae (Poupin and Bouchard, 2010)

Chaenostoma sinuspersici (Naderloo and Türkay, 2010)

Charybdis anisodon (De Haan, 1850)

Charybdis annulata (Fabricius, 1798) - Poupin et al., 2013c, 11: Glorieuses (Figure 10C). — IWP, Tanzania, Glorieuses to French Polynesia; subtidal to 50m.

Charybdis feriata (Linnaeus, 1758) - Goniosoma sexdentatum Herbst - Hoffmann, 1874: 39, Mayotte / Cancer sexdentatus Herbst, 1783 accepted as Charybdis (Charybdis) feriata in WoRMS (2018) IWP, Somalia, South Africa to Japan, New Caledonia, 1-30m.

Charybdis hellerii (A. Milne-Edwards, 1867) - Crosnier, 1962: 78, Mayotte. - Guinot, 1967b: 255, list with Mayotte - IWP, Red Sea, South Africa to Hawaii, New Caledonia, invasive in Mediterranea, Western Atlantic (e.g. Ferry et al., 2017); subtidal to 75m.

Charybdis natator (Herbst, 1794) - Goniosoma natator - Hoffmann, 1874: 39, Mayotte. - Charybdis (Charybdis) natator - Crosnier, 1962: 82, Mayotte. - Guinot, 1967b: 254, list with Mayotte - IWP, Red Sea, South Africa to Japan, Australia; 1-55m.

Charybdis obtusifrons Leene, 1937 - Poupin et al., 2013c: 11, Glorieuses (Figure 10D) - IWP, Red Sea, Glorieuses, Madagascar to Japan French Polynesia; subtidal.

Charybdis smithii MacLeay, 1838 - Charybdis edwardsi - Losse, 1969: 146, North of Mayotte [0945' S, 43 39' E] from Della Croce and Holthuis, 1965, not consulted / Charybdis (Goniohellenus) edwardsi Leene and Buitendijk, 1949 accepted as Charybdis (Goniohellenus) smithii MacLeay, 1838 in WoRMS (2018) - IO, Tanzania, South Africa to western India; littoral and pelagic at sea with observation of large oceanic swarms.

Chlorodiella barbata (Borradaile, 1900) - Guinot, 1967b: 262, list with Mayotte. - Serène, 1984: 260, Glorieuses, intertidal, coll. J. Millot 16 September 1958, 1 + 4.6×7.4 mm, MNHN-B 6712 — IWP, Mayotte, Europa, Madagascar to Guam, French Polynesia; shallow subtidal. 
Chlorodiella cytherea (Dana, 1852) - Serène, 1984: 259, Mayotte, intertidal, coll. A. Crosnier August 1959, 2 ऊึ $4.2 \times 6.9$ mm, 5.1×8.1 mm, MNHN-B8094. - Poupin et al., 2013c: 11, Glorieuses - IWP, Red Sea, Somalia, Mayotte, Madagascar, Réunion to Hawaii, Easter Island; intertidal, subtidal.

Chlorodiella laevissima (Dana, 1852)

Chlorodiella nigra (Forskål, 1775)

Coleusia signata (Paul'son, 1875) - Galil, 2006: 62, Mayotte, coll. M. Cloué, 1ðึ MNHN B17532 WIO, Red Sea, Mozambique to Madagascar, invasive in Mediterranean (cf. Galil et al., 2018); 1-10m.

Coralliocryptus caementa Komai and Ng, 2012

Corycodus spinosus Naruse, 2013: 491, Leven Bank, south of Glorieuses, MIRIKY st. DW 3196, $12^{\circ} 08^{\prime}$ S, $48^{\circ} 56^{\prime}$ E, 238-249m, 18.06.2009, 1 ㅇ ov. 5.0×9.8 mm, MNHN IU-2010-311 — WIO, only Leven Bank, between Glorieuses and Madagascar; 238-249m.

Cranuca inversa (Hoffman 1874)

Crossotonotus spinipes (De Man, 1888) - Castro, 2013: 439, Leven Bank, between Glorieuses and

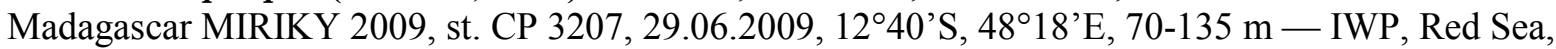
Mozambique Channel to Hawaii, Samoa; intertidal to $146 \mathrm{~m}$ and up to 500 from tangle nets ( $c f$. Castro 2011).

Cryptodromia fallax (Latreille, in Milbert, 1812) - Cryptodromia canaliculata - Lewinsohn, 1984:

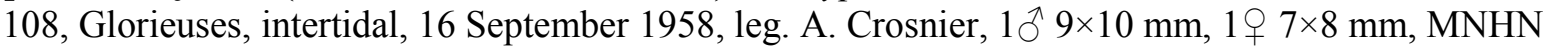

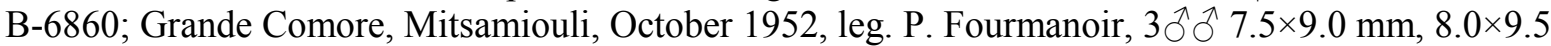
mm, 9×11 mm, MNHN B-6862; Mayotte, leg. Humblot, 19012 우, 1 ㅇ ov., part MNHN B-6862 / Cryptodromia canaliculata Stimpson, 1858 accepted as Cryptodromia fallax in WoRMS (2018) IWP, Red Sea, South Africa to Hawaii, French Polynesia; shallow subtidal.

Cryptodromia hilgendorfi De Man, 1888 - Lewinsohn, 1984: 109, Mayotte, leg. Humblot, 1901, 1ð̂, 1 , part of MNHN B-6946 — IWP, Red Sea, Comoros to French Polynesia; intertidal to 105m.

Cryptodromiopsis tridens Borradaile, 1903 - Lewinsohn, 1984: 113, Glorieuses, intertidal, 16 September 1958, leg. A. Crosnier, 2 + $ᄋ 6.5 \times 7.5 \mathrm{~mm}$ [?largest], MNHN B-6859; intertidal, 30 January 1971, leg. A. Crosnier, $3 \circ$ 우 19 ov. $6.5 \times 7.0$ mm [?largest], MNHN B-6893 — IWP, Somalia to French Polynesia; shallow subtidal.

Cyclax spinicinctus Heller, 1861

Cycloachelous granulatus (H. Milne Edwards, 1834) - Portunus granulatus - Crosnier, 1962: 57 , Mayotte, MNHN. - Guinot, 1967b: 257, list with Mayotte. - Poupin et al., 2013c: 11, Glorieuses (Figure 10E) - IWP, Red Sea, South Africa to Japan, French Polynesia; subtidal to $120 \mathrm{~m}-$ REMARKS - Records of this species in Hawaii now accepted as Cycloachelous suborbicularis (Stephenson, 1975) (cf. Castro, 2011).

Cyclodius drachi (Guinot, 1964b)

Cyclodius granulosus De Man, 1888

Cyclodius nitidus (Dana, 1852)

Cyclodius obscurus (Hombron and Jacquinot, 1846) - Phymodius monticulosus - Guinot, 1958a: 93, Mayotte, 1 ov. 13.0×9.5 mm MNHN. - Guinot, 1967b: 267, list with Mayotte / Chlorodius (Cyclodius) monticulosus Dana, 1852 accepted as Cyclodius obscurus (Hombron and Jacquinot, 1846) in WoRMS (2018) - IWP, Red Sea, South Africa to Hawaii, French Polynesia; intertidal, shallow subtidal.

Cyclodius ungulatus (H. Milne Edwards, 1834)

Cymo andreossyi (Audouin, 1826) - Guinot, 1958b: 181, Mayotte, $4 \hat{\jmath} \widehat{\jmath}, 2 q \circ$, largest 10×9 mm, MNHN. - Guinot, 1967b: 263, list with Mayotte. - Serène, 1984: 31, Mayotte, $1{ }^{1} 10 \times 9 \mathrm{~mm}, \mathrm{MNHN}$ - IWP, Red Sea, South Africa to Japan, French Polynesia; shallow water.

Cymo deplanatus A. Milne-Edwards, 1873 
Cymo melanodactylus Dana, 1852

Cymo quadrilobatus Miers, 1884

Daira perlata (Herbst, 1790) - Mayotte, photo Norbert Verneau, Moya reef, 3m, det. J. Poupin, specimen not collected (photo in Legall and Poupin, 2018) - REMARKS - A crab common on forereef, although rarely collected - IWP, Red Sea, Mayotte (present study), South Africa to Hawaii, French Polynesia; subtidal to $10 \mathrm{~m}$.

Daldorfia horrida (Linnaeus, 1758) (Figure 9E) - Tan and Ng, 2007: 130, Glorieuses, intertidal, coll. A. Crosnier, 29 January $1971,1 \hat{\jmath} 63.3 \times 47.2 \mathrm{~mm}, \mathrm{MNHN}$. - Poupin et al., 2013c: 11 Glorieuses, $1{ }^{\lambda}$ (approximately $38 \times 40 \mathrm{~mm}$ ) MNHN-IU-2013-7341 — IWP, Red Sea, South Africa to Japan, French Polynesia; intertidal to $125 \mathrm{~m}$.

Daldorfia leprosa (Nobili, 1905)

Daldorfia rathbunae (De Man, 1902)

Discoplax rotunda (Quoy and Gaimard, 1824) - Poupin et al., 2013c: 12, Glorieuses - IWP, Mayotte, Mauritius to Japan, Guam, French Polynesia; supratidal and land. Records from Hawaii probably from mislabeled specimens ( $c f$. Castro, 2011).

Domecia glabra Alcock, 1899

Domecia hispida Eydoux and Souleyet, 1842

Dotilla fenestrata Hilgendorf, 1869

Dromidiopsis tridentata Borradaile, 1903 - Balss, 1934: 502, Mayotte, $2 q q$ MNHN, leg. A. MilneEdwards. - Lewinsohn, 1984: 97, Comoros (Anjouan), intertidal, November 1961, leg. A. Crosnier, 1 ภิ 9.5 $\times 10.0$ mm, MNHN B-6882; Glorieuses, intertidal, coll. 16 September 1958, leg. A. Crosnier, 1 juv. $4.5 \times 4.5 \mathrm{~mm}$, MNHN B-6887; Mayotte, leg. A. Milne Edwards, det. Balss 1 ㅇ (on two), MNHN B-6963 (same sp. than Balss, 1934). - Guinot, 1967b: 239, list with Mayotte - IWP, Kenya, Comoros to Chesterfield Islands, New Caledonia; intertidal to $62 \mathrm{~m}$.

Dynomene hispida (Latreille, in Milbert, 1812) - Dynomene hispida - Poupin et al., 2013c: 10, Glorieuses - IWP, Somalia, Madagascar to Hawaii, French Polynesia and Easter Island; intertidal to $48 \mathrm{~m}$ (Easter Island and $48 \mathrm{~m}$ from $\mathrm{Ng}$ and Boyko, 2017).

Dynomene praedator A. Milne-Edwards, 1879 - Dynomene praedator - McLay, 1999: 481, Glorieuses, coll. A. Crosnier, 29 January 1971, intertidal, $1 \overbrace{}^{\lambda} 8.7 \times 6.7 \mathrm{~mm}, 1$ q ov. $9.6 \times 7.5 \mathrm{~mm}$, MNHN.

Epiactaea margaritifera (Odhner, 1925) - Actaea margaritifera - Guinot, 1958a: 89, Mayotte, $1 \widehat{\jmath}$ juv. $6.2 \times 4.5$ mm, MNHN. - Guinot, 1967b: 261, list with Mayotte. - Epiactaea margaritifera - Serène, 1984: 117, Mayotte in distribution - IWP, Red Sea, Mayotte to Gulf of Thailand, Kei Islands, Australia (Torres Strait); subtidal.

Epixanthus corrosus A. Milne-Edwards, 1873

Epixanthus dentatus (White, 1848)

Epixanthus frontalis (H. Milne Edwards, 1834)

Eriphia scabricula Dana, 1852

Eriphia sebana (Shaw and Nodder, 1803)

Eriphia smithii MacLeay, 1838

Ethusa sinespina Kensley, 1969 - Ethusa sinespina - Castro, 2013: 439, Leven Bank, south of Glorieuses, MIRIKY 2009, st. CP 3185, 26.06.2009, $12^{\circ} 38^{\prime}$ 'S, $48^{\circ} 10^{\prime} \mathrm{E}, 560-576 \mathrm{~m}$, st. CP 3222 , 01.07.2009, $12^{\circ} 42^{\prime}$ S, $48^{\circ} 11^{\prime}$ E, 584-624 m - WIO, South Africa to Madagascar; 138-680m.

Etisus anaglyptus $\mathrm{H}$. Milne Edwards, 1834

Etisus demani Odhner, 1925

Etisus dentatus (Herbst, 1785) 
Etisus frontalis (Dana, 1852)

Etisus odhneri Takeda, 1971

Etisus splendidus Rathbun, 1906

Etisus utilis Jacquinot, in Jacquinot and Lucas, 1853

Eupilumnus calmani (Balss, 1933)

Euxanthus exsculptus (Herbst, 1790)

Euxanthus rugosus Miers, 1884 - Serène, 1984: 85, Glorieuses, intertidal, coll. A. Crosnier 30 January

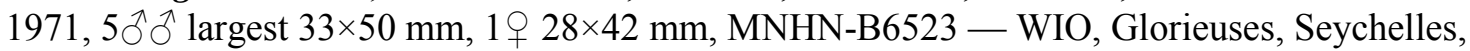
Europa, Madagascar, Mauritius to Chagos, Maldives; intertidal.

Forestiana depressa (White, 1848) - Serène, 1984: 106, Glorieuses, Island du Lys, intertidal, coll. A. Crosnier 29 January 1971, 1 ㅇ $17 \times 23$ mm, MNHN-B 6557 — IWP, Somalia, South Africa to Hawaii, ?French Polynesia [perhaps Forestia scabra (Odhner, 1925) there; cf. Guinot (1976), Serène (1984)]; intertidal, subtidal.

Gaillardiellus rueppelli (Krauss, 1843)

Gandoa brevipes (H. Milne Edwards, 1853 - Pinnixia brevipes H. Milne Edwards, 1853: 220, Madagascar. - Gandoa brevipes - Ng and Naruse, 2009: 288, lectotype female 5.1 $\times 8.5 \mathrm{~mm}$, Mayotte, Comoro Is., coll. Cloué, MNHN B-10616; new generic combination with this remark 'Type locality Mayotte, on associated label written by Serène, contradicts that sated by H. Milne Edwards [Madagascar]'. - Ahyong and Ng, 2009: 39, Mayotte, same lectotype MNHN B-10616 - Ng and Rahayu, 2016: 365, Mayotte, same specimen — WIO, Kenya (Zanzibar), Mayotte; shallow water, perhaps with a polychaete worm.

Gelasimus hesperiae (Crane, 1975)

Gelasimus tetragonon (Herbst, 1790)

Geograpsus crinipes (Dana, 1851)

Geograpsus grayi (H. Milne Edwards, 1853)

Glabropilumnus laevimanus (Dana, 1852)

Gonioinfradens paucidentatus (A. Milne-Edwards, 1861)

Grapsus fourmanoiri Crosnier, 1965

Grapsus longitarsis Dana, 1851 - Poupin et al., 2013c: 12, Glorieuses — IWP, Red Sea, Somalia to Hawaii, French Polynesia; intertidal, supratidal.

Grapsus tenuicrustatus (Herbst, 1783)

Hemisphaerodromia monodus (Stebbing, 1918) - Hemisphaerodromia abellana - Lewinsohn, 1984: 117, 'Comoros or Madagascar no detail', leg. P. Fourmanoir, 1 § $13.5 \times 15.5$ mm, MNHN B-6857 / Hemisphaerodromia abellana Barnard, 1954 accepted as Hemisphaerodromia monodus in WoRMS (2018) - WIO, Red Sea, South Africa to 'Comoros or Madagascar'; intertidal to subtidal REMARKS - This species probably reported by error from New Caledonia in Ng and Richer de Forges (2007, as Hemisphaerodromia abellana Barnard, 1954), followed by Poupin (2010). This is perhaps because this species (H. monodus/abellana) is listed in McLay (1993) study on 'The sponge crabs from New Caledonia and Philippines' but no specimen(s) have been examined from New Caledonia in McLay contribution.

? Hiplyra elegans (Gravier, 1920)

Hirsutodynomene spinosa (Rathbun, 1911)

Homolochunia valdiviae Doflein, 1904 - Homolochunia valdiviae - Guinot and Richer de Forges, 1995 : 430, Mayotte, coll. BENTHEDI, 29 March 1977, st. F61, 1246'S, 445ㅗ' E, 475-510m, 1 q ov. $35.7 \times 25.8 \mathrm{~mm}$, MNHN B24270 — IWP, Mozambique, Madagascar to New Caledonia; 395-1000m.

Huenia brevifrons Ward, 1941 
Huenia grandidierii A. Milne-Edwards, 1865

Hyastenus uncifer Calman, 1900

Hypocolpus diverticulatus (Strahl, 1861)

Kabutos durandi (Serène, 1955)

Kraussia rugulosa (Krauss, 1843)

Lachnopodus subacutus (Stimpson, 1858)

Lahaina incerta (Balss, 1938)

Lahaina ovata Dana, 1851

Laleonectes nipponensis (Sakai, 1938)

Lambrachaeus ramifer Alcock, 1895

Latopilumnus malardi (de Man, 1914)

Latreillia metanesa Williams, 1982 - Latreillia metanesa - Castro, 2013: 439, Leven Bank, south of Glorieuses MIRIKY 2009, st. CP 3188, 27.06.2009, 12³1'S, 48²2’'E, 298-301m, st. CP 3189, 27.06.2009, 12³0'S, 48 $18^{\circ}$ 'E, 346-376 m - IWP, Somalia, Kenya, Mozambique to Hawaii, French Polynesia, Nazca ridges; 22-806m.

Latreillia pennifera Alcock, 1900 - Latreillia pennifera - Castro, 2013: 439, Leven Bank, south of Glorieuses, MIRIKY 2009, st. CP 3205, 29.06.2009, 12³7.64'S, 48²5.99'E, 60-63 m; st. DW 3206, 29.06.2009, $12^{\circ} 38.71$ 'S , $48^{\circ} 21.52$ 'E, $70-74 \mathrm{~m}$ - IWP, Mozambique Channel, South Africa to New Caledonia; $37-411 \mathrm{~m}$.

Leptodius exaratus (H. Milne Edwards, 1834)

Leptodius gracilis (Dana, 1852)

Leptodius nudipes (Dana, 1852)

Leptodius sanguineus (H. Milne Edwards, 1834)

Lewindromia unidentata (Rüppell, 1830) - Dromidia unidentata - Balss, 1934: 502, Mayotte, Humblot leg. MNHN. - Guinot, 1967b: 240, list with Mayotte. - Lewinsohn, 1984: 107, Mayotte, same specimen than Balss (1934), leg. Humblot 1901, det. Balss, 1 ○ $^{\Uparrow} 13 \times 13$ mm, MNHN B-6936 — IWP, Red Sea, Mozambique to Hawaii, Easter Island; intertidal to $122 \mathrm{~m}$.

Libystes nitidus A. Milne-Edwards, 1867 - Barnard, 1954: 100, Mayotte, Bandrélé, intertidal. Crosnier, 1962: 14, Mayotte, 1 sp. $8.0 \times 13.6 \mathrm{~mm}$, MNHN. - Guinot, 1967b: 253, list with Mayotte IWP, Red Sea, Tanzania, Madagascar to Indonesia, New Caledonia; subtidal to $187 \mathrm{~m}$ - REMARKS This species has been reported in Taiwan, Philippines and Hawaii (e.g. Sakai, 2004) but these records should be verified as the genus Libystes is in need of revision (Apel and Spiridonov, 1998). Several records from the Pacific Ocean must belong to a complex of species affiliated to Libystes villosus Rathbun, 1924, a species described from Samoa, later reported from Hawaii and for long considered as a junior synonym of L. nitidus (see remarks in Castro, 2011: 66).

Linnaeoxantho acanthomerus (Rathbun, 1911)

Liocarpilodes armiger (Nobili, 1905)

Liocarpilodes integerrimus (Dana, 1852) - Poupin et al., 2013c: 11, Glorieuses, $1 \lesssim 2.3 \times 3.2 \mathrm{~mm}$, MHNH-IU-2013-7314 (Figure 15E). - Coll. Anker and Michonneau, 2008, Mayotte, st. MAY08-St5, reef at S-shaped Pass, UFID 13612 - IWP, Red Sea, Somalia, Mayotte, Madagascar to Hawaii, French Polynesia; shallow subtidal.

Liomera albolineata (Serène and Nguyen, 1960)

Liomera bella (Dana, 1852)

Liomera cinctimana (White, 1847)

Liomera edwardsi Kossmann, 1877

Liomera guttata de Man, 1888 
Liomera laevis (A. Milne-Edwards, 1873)

Liomera monticulosa (A. Milne-Edwards, 1873)

Liomera rubra (A. Milne-Edwards, 1865)

Liomera rugata (H. Milne Edwards, 1834) - Serène, 1984: 62, Glorieuses, coll. J. Millot and A. Crosnier 16 September 1958, $3 \widehat{\partial} \widehat{\jmath}$ largest $6.5 \times 11.0 \mathrm{~mm}$, MNHN-B6500 — IWP, Red Sea, South Africa to Hawaii, French Polynesia, Easter Island; intertidal, subtidal.

Liomera rugipes (Heller, 1861) - Carpilodes rugipes - Guinot, 1958a: 84, Mayotte, 1ठ 12.0×7.3 mm, MNHN. - Liomera rugipes - Guinot, 1967b: 265, list with Mayotte. - Serène, 1984: 52, 1 đ $7.3 \times 12.0$ mm, Mayotte, MNHN. - Coll. Anker and Michonneau, 2008, Mayotte, st. MAY08-St2, Tanaraki reef, UFID 13590 - IWP, Red Sea, Somalia, Mayotte, Madagascar to Vietnam (in Serène, 1968); intertidal, subtidal - REMARKS - This species is rarely reported, affiliated to L. rubra (A. MilneEdwards, 1865). Serène (1984) and Galil and Vannini (1990) have examined specimens from Madagascar and Somalia, respectively.

Liomera stimpsonii (A. Milne-Edwards, 1865)

Liomera striolata (Odhner, 1925)

Liomera tristis (Dana, 1852) - Carpilodes tristis - Guinot, 1958a: 85, Mayotte, $1 \hat{\jmath} 19.5 \times 11.5 \mathrm{~mm}$, MNHN. - Guinot, 1967b: 265, list with Mayotte. - Liomera tristis - Serène, 1984: 59, 1 đ $15.5 \times 26.0$ mm, coll. A. Crosnier August 1959, Mayotte, MNHN-B6486 - IWP, Red Sea, South Africa to Hawaii, French Polynesia; intertidal, shallow subtidal.

Lissocarcinus orbicularis Dana, 1852

Lophozozymus anaglyptus (Heller, 1861) - Platypodia anaglypta - Serène, 1984: 159, Comoros (Anjouan), intertidal, coll. A. Crosnier November 1961, 19 11.7×18.1 mm, MNHN-B6607 — IWP, Red Sea, Comoros (Anjouan), Madagascar to Japan, French Polynesia; intertidal, subtidal.

Lophozozymus edwardsi Odhner, 1925

Lophozozymus pulchellus A. Milne-Edwards, 1867

Lupocyclus quinquedentatus Rathbun, 1906

Lybia plumosa Barnard, 1947

Lybia tessellata (Latreille, in Milbert, 1812)

Lydia annulipes (H. Milne Edwards, 1834)

Macromedaeus nudipes (A. Milne-Edwards, 1867) - Serène, 1984: 178, Glorieuses, Island du Lys,

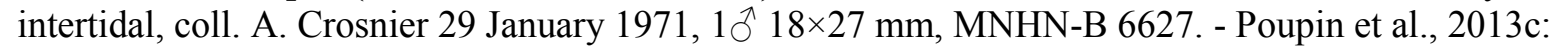
11, Glorieuses - IWP, Seychelles, Aldabra, Glorieuses, Europa, Madagascar to Guam, French Polynesia; intertidal, subtidal.

Macromedaeus voeltzkowi (Lenz, 1905) - Xantho (Leptodius) voeltzkowi - Balss, 1934: 507, Mayotte, Millot leg. MNHN. - Guinot, 1967b: 265, list with Mayotte. - Macromedaeus voeltzkowi - Serène, 1984: 178, Mayotte (in distribution) - WIO, Gulf of Oman, Red Sea, South Africa to Madagascar; intertidal, subtidal.

Macrophthalmus depressus Rüppel, 1830

Macrophthalmus grandidieri A. Milne-Edwards, 1867

Macrophthalmus milloti Crosnier, 1965 - Legall and Poupin (2018), Mayotte, photograph only (L. Bigot, 2011), determined with confidence by J. Poupin based on drawings and photos in Crosnier (1965:124, fig. 217-220, 222-223, 228, pl. XI fig. 4). - REMARKS - Affiliated species having also long ocular peduncles are Macrophthalmus transversus (Latreille, 1817), Macrophthalmus latipes Borradaile, 1903 and Macrophthalmus telescopicus (Owen, 1839) - IWP, Tanzania, Kenya, Mayotte (present study), Madagascar to Japan (Ryukyu), New Caledonia; lower intertidal.

Macrophthalmus telescopicus Owen, 1839 - Crosnier, 1975: 737, Comoros (Grande Comore), 'Trou du Prophète, Im, sablons coralliens', 13 October 1969, coll. R. Plante, 1 sp. 15.7×25.4 mm; Mayotte 
(Bouénie Bay), 55m, dredge, mud-sand, 21 January 1970, coll. R. Plante, 1 sp. 9.6×16.0 mm; same coll. and place, $26 \mathrm{~m}, 1 \mathrm{sp}$. ov. $7.9 \times 13.0 \mathrm{~mm}$. - Macrophthalmus (Macrophthalmus) telescopicus Bouchard et al., 2013: 37, list with Mayotte and same spp. than Crosnier (1975) - IWP, Red Sea, Tanzania, Comoros, Madagascar to Japan, Hawaii, Fiji; soft sediments in shallow subtidal to $55 \mathrm{~m}$.

Matuta victor (Fabricius, 1781)

Medaeops neglectus (Balss, 1922) - Medaeus granulosus - Balss, 1934: 507, Mayotte, Millot leg. MNHN. - Guinot, 1967b: 266, list with Comoros / Not Medaeops granulosus (Haswell, 1882), redetermined as M. neglectus by Guinot (1967c: 367), Serène (1984: 91) — WIO, Red Sea, Kenya, Mayotte, South Africa to Madagascar; intertidal, subtidal.

Menaethiops brevicornis (A. Milne-Edwards, 1868)

Menaethiops contiguicornis (Klunzinger, 1906)

Menaethiops nodulosus (Nobili, 1905)?

Menaethius monoceros (Latreille, 1825)

Menaethius orientalis (Sakai, 1969)

Metadynomene crosnieri McLay, 1999: 530, Glorieuses, 7 June 1977, BENTHEDI, 11³2.00'S $47^{\circ} 16.40^{\prime} \mathrm{E}, 330-440 \mathrm{~m}, 1+23.2 \times 22.7 \mathrm{~mm}, \mathrm{MNHN}$ B22510. - Cleva et al., 2007: 248, type catalog in Paris MNHN, holotype from Glorieuses.

Metasesarma obesum (Dana, 1851)

Metaxanthops acutus Serène, 1984

Metopograpsus messor (Forskål, 1775)

Metopograpsus thukuhar (Owen, 1839)

Micippa platipes Rüppell, 1830

Micippa thalia (Herbst, 1803)

Monodaeus tuberculidens (Rathbun, 1911) s.l.

Myrine kessleri (Paul'son, 1875) - Galil, 2001: 436, Mayotte lagoon, coll. A Crosnier, 55m, August 1960, 1 ㅇ CL 12.1 mm, MNHN B18593; 46m, 5 March 1959, 1 ㅇ CL 11.7 mm, MNHN B18590; 20m, September 1959, 1 ㅇ CL 12.0 mm, MNHN B18591 — IWP, Red Sea, Mayotte to Fiji; 15-320m.

Nanocassiope alcocki (Rathbun, 1902)

Nanosesarma jousseaumei (Nobili, 1905)

Neoliomera sabaea (Nobili, 1905)

Neoliomera themisto (De Man, 1889)

Neopalicus jukesii (White, 1847) - Castro, 2000: 554, Mayotte, 50m, coarse sand, A. Crosnier coll. 09.1958, 10 MNHN B27216. - Castro, 2013: 439, Leven Bank, between Glorieuses and Madagascar MIRIKY 2009, st. CP 3204, 29.06.2009, 12³7.03’S, 48³0.3'E, 59-60 m — IWP, Red Sea, Gulf of Aden, Mayotte, Madagascar to Japan, New Caledonia; 10-146m.

Neosarmatium meinerti (De Man, 1887)

Neosarmatium smithi (H. Milne Edwards, 1853)

Neoxanthias impressus (Latreille, in Milbert, 1812) - Serène, 1984: 201, Mayotte, intertidal, coll. A. Crosnier September 1959, 1ठ 27.5×45.2 mm, MNHN-B6661. - Poupin et al., 2013c: 11, Glorieuses (see Figure 16J, specimen not located in FLMNH collection, perhaps not collected) - IWP, Mozambique, Mayotte, Europa, Glorieuses, South Africa to Japan, New Caledonia and probably to

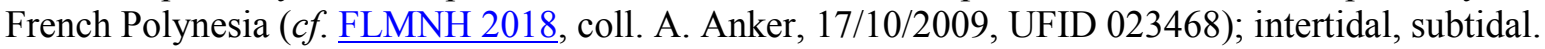

?Nepinnotheres pectinicola (Bürger, 1895)

Nucia speciosa Dana, 1852

Ocypode ceratophthalmus (Pallas, 1772)

Ocypode cordimanus Latreille, 1818 
Ocypode pauliani Crosnier, 1965: 102, Comoros (Grande Comore). - Guinot, 1967b: 281, list with Comoros - WIO, Mayotte, Madagascar; supratidal (see 'Comment' for that species in Bouchard et al., 2013: 41).

Oncinopus araneus (De Haan, 1839)

Oreophorus horridus Rüppell, 1830

Ozius guttatus H. Milne Edwards, 1834 - Photographs Norbert Verneau, 2017 - Mayotte, Pamanzi foreshore along 'rue de la plage' (2010), CW about $60 \mathrm{~mm}$; mudflats, Badamiers low tide (2011), CW about $90 \mathrm{~mm}$ - REMARKS - No specimens collected for this species, determination with confidence (J. Poupin, 13/12/2017) from photographs only (see Figure 19L and more photos in Legall and Poupin, 2018). This is a common IWP species but nonetheless a first record herein for Mayotte. A key for WIO Ozius is in Crosnier (1984: 305) with illustrations - IWP, Red Sea, Mayotte (present study), Madagascar to Japan, New Caledonia, Samoa; intertidal.

Ozius rugulosus Stimpson, 1858

Pachygrapsus minutus A. Milne-Edwards, 1873

Pachygrapsus planifrons De Man, 1888

Pachygrapsus plicatus (H. Milne Edwards, 1837) - Crosnier, 1965: 27, Glorieuses. - Guinot, 1967b: 285, list with Glorieuses. - Poupin et al., 2013c: 12, Glorieuses, 2 spp. MNHN-IU-2013-7325 - IWP, Mozambique, South Africa to Hawaii, French Polynesia, Easter Island (cf. Boyko and Liguori, 2015).

Palapedia integra (De Haan, 1835)

Palicoides whitei (Miers, 1884) - Castro, 2000: 565, Mayotte, lagoon, medium-size sand, 55m, A. Crosnier coll., 09.1958: 1 + MNHN — IWP, Red Sea, Mayotte to Japan, New Caledonia; 7-70m.

Paractaea retusa (Nobili, 1905)

Paractaea rufopunctata (H. Milne Edwards, 1834) s.l.

Paraleptuca chlorophthalmus (H. Milne Edwards, 1837)

Paramaja gibba (Alcock, 1895) - Ng and Richer de Forges, 2015: 133, Leven Bank, between Glorieuses and Madagascar, MIRIKY 2009, several stations north of latitude $13^{\circ} \mathrm{S}$ and longitudes 47$48^{\circ} \mathrm{E}$ - IWP, Mozambique Channel to Japan; 230-600m.

Paramedaeus octogesimus Ng and Clark, 2002 - Poupin et al., 2013c: 11, Glorieuses, $1 q$ ov. $10.4 \times 14.8 \mathrm{~mm}, \mathrm{MNHN}-\mathrm{IU}-2013-7354$ (Figure 16N) - IWP, Mayotte (present study), reported by Ng and Clark (2002) from Coco-Keeling Islands, Hawaii; probably also Marquesas Islands from data and photos in Legall and Poupin (2018); subtidal to 20-23m.

Paramedaeus simplex (A. Milne-Edwards, 1873) s.l. - Coll. Anker and Michonneau, 2008, Mayotte, st. MAY08-St4, Sada, Tahiti Beach, fringing reef, UFID 13659. - Poupin et al., 2013c: 11, Glorieuses, 1 juv. 5.9×7.8 mm, MNHN-IU-2013-7355 (see Figure 17A) - REMARKS - Specimens from Glorieuses determined with description and photographs in Ng and Clark (2002). According to these authors, and also Mendoza and $\mathrm{Ng}$ (2010), P. simplex is a species complex of species, in need of revision - IWP, Red Sea, Somalia, Mayotte, Glorieuses, Madagascar to Hawaii, French Polynesia; intertidal, subtidal.

Parapilumnus cristimanus (A. Milne-Edwards, 1873)

Parasesarma leptosoma (Hilgendorf, 1869)

Paromolopsis boasi Wood-Mason in Wood-Mason and Alcock, 1891 - Paromolopsis boasi - Guinot and Richer de Forges, 1995: 355, Mayotte, coll. BENTHEDI, 29 March 1977, st F61, 'Grande Passe de l'Ouest', 1246'S, 445'ㄹ, 450m, 1 q ov., MNHN B19886 - IWP, Mayotte, Madagascar to Japan, New Caledonia; 284-1124m.

Percnon abbreviatum (Dana, 1851) - Crosnier, 1965: 88, Glorieuses. - Guinot, 1967b: 289, list with Glorieuses - IWP, Tanzania, Glorieuses, Madagascar to Hawaii, French Polynesia and some islands of eastern Pacific (Revillagigedo, Clipperton); low intertidal, shallow subtidal. 
Percnon guinotae Crosnier, 1965

Percnon planissimum (Herbst, 1804)

Perisesarma guttatum (A. Milne-Edwards, 1869)

Pilodius areolatus (H. Milne Edwards, 1834)

Pilodius pugil Dana, 1852 - Chlorodopsis pugil - Guinot, 1958b: 180, Mayotte, 1 đิ 9×13 mm MNHN-

B6782. - Pilodius pugil - Guinot, 1967b: 268, list with Mayotte. - Serène, 1984: 242, Mayotte, coll. M.

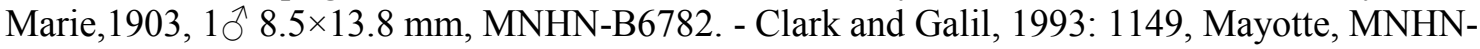
B6782. - Poupin et al., 2013c: 11, Glorieuses (Figure 17C) - REMARKS - In Mayotte KUW 2009 field notes two juveniles of Pilodius pugil are indicated at st. 17, North Reef, $22 \mathrm{~m}$ but they were not located in MNHN collection for this work (probably lost) - IWP, Red Sea, South Africa to Japan, Guam, French Polynesia; intertidal, shallow subtidal.

Pilodius scabriculus Dana, 1852 - Serène, 1984: 244, Glorieuses, intertidal, coll. J. Millot September $1958,1 \circlearrowleft 6.5 \times 10.2 \mathrm{~mm}, 1$ ㅇ 5.5×8.7 mm, MNHN-B6733 — IWP, Glorieuses, Mozambique Channel (Europa) to Guam, Bikini, French Polynesia; intertidal, subtidal.

Pilodius spinipes (Heller, 1861)

Pilumnus ?fissifrons Stimpson, 1858 ?

Pilumnus aff. turgidulus Rathbun, 1911

Pilumnus longicornis Hilgendorf, 1878

Pilumnus vespertilio (Fabricius, 1793)

Plagusia immaculata Lamarck, 1818 - Poupin et al., 2013c: 12, Glorieuses, under a drifting buoy, $1 \overbrace{}^{\lambda}$ $17.6 \times 19.4 \mathrm{~mm}, 1$ ㅇ $18.0 \times 19.8 \mathrm{~mm}$ MNHN-IU-2013-7320 — IP, Somalia, Mayotte (see remarks), Glorieuses, Madagascar to Hawaii, Clipperton, Coco, Galapagos, eastern Pacific (Gulf of California to Mexico); low intertidal, shallow subtidal, and on flotsam and ship's hulls - REMARKS - This species is probably also in Mayotte, recognized with hesitation by J. Poupin on an underwater photograph transmitted by Norbert Verneau during this work (15/12/2017; photos in Legall and Poupin, 2018),

Plagusia squamosa (Herbst, 1790)

Planes major (MacLeay, 1838) — Poupin et al., 2013c: 12, Glorieuses (drifting with a buoy) Worldwide, South East Atlantic; IP from Mozambique, South Africa to Hawaii, French Polynesia, and eastern Pacific, California to Peru; pelagic.

Planopilumnus spongiosus (Nobili, 1906)

Platyozius laevis (Borradaile, 1902) - Poupin et al., 2013c: 11, Glorieuses. - Castro, 2013: 439, Leven Bank, south of Glorieuses, MIRIKY 2009 st. CP 3203, 29.06.2009, 12³5.92’S, 48³5.22’E, 50-52 m - IWP, Glorieuses, Juan de Nova to Hawaii, French Polynesia; intertidal, 241m. It seems that this species has never been reported from the east African coast, westernmost IWP record being currently Juan de Nova, Mozambique Channel (cf. Poupin, 2016).

Platypodia granulosa (Rüppell, 1830)

Platypodia morini (Ward, 1942)

Polydectus cupulifer (Latreille, in Milbert 1812)

Portunus (Xiphonectes) cf. longispinosus (Dana, 1852)

Portunus convexus De Haan, 1835

Portunus mariei Guinot, 1957

Portunus sanguinolentus (Herbst, 1783) - Mayotte, only photographs by N. Verneau, Dzaoudzi harbor at night, sand bottom, $3 \mathrm{~m}$ and by fishermen in front of mangrove ('Djarifa', fishing). Determination from photos with confidence (J. Poupin) based on color pattern (three red/brown spots on posterior carapace; see photos in Legall and Poupin, 2018) - IWP, Somalia, Mayotte (present study), South Africa to Japan, Guam, New Caledonia; subtidal to 78 m - REMARKS - Portunus (Portunus) sanguinolentus hawaiiensis Stephenson, 1968 is elevated to species level and distinct from $P$. 
sanguinolentus (Herbst, 1783) s.s. in Castro (2011; following $\mathrm{Ng}$ and Lai pers. comm.). Portunus hawaiiensis is distributed with certainty in Hawaii and French Polynesia but other records of $P$. sanguinolentus s.l. in western Pacific (e.g. Guam, New Caledonia) should be verified as they could be also of $P$. hawaiiensis.

Psaumis cavipes (Dana, 1852)

Pseudactaea multicristata (Zehntner, 1894)

Pseudograpsus albus Stimpson, 1858

Pseudohelice subquadrata (Dana, 1851)

Pseudoliomera helleri (A. Milne-Edwards, 1865)

Pseudoliomera speciosa (Dana, 1852)

Pseudoliomera variolosa (Borradaile, 1902)

Pseudopalicus sexlobatus (Kensley, 1969) - Castro, 2013: 439, Leven Bank, between Glorieuses and Madagascar MIRIKY 2009, st. DW 3215, 30.06.2009, 12³2’'S, 4754’E, 316-433 m — WIO, Mozambique, Madagascar, Mauritius; 110-442m.

Pseudozius caystrus (Adams and White, 1849)

Psopheticus crosnieri Guinot, 1990: 351, Mayotte, coll. BENTHEDI, st. F61, 'Grande Passe de l'Ouest',

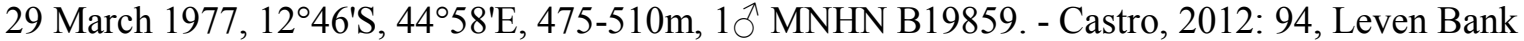
south of Glorieuses MIRIKY 2009 , several stations north of $13^{\circ} \mathrm{S}$ and near $47-48^{\circ} \mathrm{E}-\mathrm{WIO}$, Mozambique to Réunion; 53-730m.

Ptychognathus barbatus (A. Milne-Edwards, 1873) - Keith et al., 2006: 36, Comoros (Anjouan, Mohéli). - Bouchard et al., 2013: 30, fig. 25A, Comoros, same as Keith et al. (2006) - IWP, Comoros (Anjouan, Mohéli), Madagascar to Japan, Wallis and Futuna; land, fresh/brackish water.

Ptychognathus johannae Rathbun, 1914: 354, pl. 30, 'Johanna Island' (alternate name used in the past for Anjouan Island), coll. Hildebrandt; in USNM received in exchange from the Berlin Museum; $1 \overbrace{}^{\lambda}$, type Cat. N²2799 USNM, formerly $\mathrm{N}^{\circ}$ 4598, Berlin Museum. - Guinot, 1967b: 286, list with Comoros. - Bouchard et al., 2013: 31, fig. 25C-D, same as Rathbun (1914) with photographs of the type (by Christopher Escano Mendoza, transmitted by Ng Ngan Kee) with comment on taxonomy WIO, known with certainty only from Comoros (Anjouan), one record from Japan being an error for Ptychognathus hachijoensis Sakai, 1955 (see Osawa and Ng, 2006); land, fresh/brackish water.

Ptychognathus pusillus Heller, 1865 - Keith et al., 2006: 36, Comoros (Anjouan, Mohéli). - Bouchard et al., 2013, 31, fig. 25B, same as Keith et al. (2006) - IWP, Comoros (Anjouan, Mohéli) to Japan, Fiji; land, fresh/brackish water.

Pycnoplax coryphaea Castro, 2012 - Castro, 2013: 439, Leven Bank, south of Glorieuses, MIRIKY 2009, st. DW 3196, 28.06.2009, 1208'S, 4856'E, 238-249 m - WIO, only Mozambique Channel, from off Mozambique to Leven bank; 238-698m.

Quadrella coronata Dana, 1852 - Castro, 1999a: 95, Mayotte, Pass Longoni-M'tzamboro $40 \mathrm{~m}$ on white gorgonian, April 1995, coll. J. C. Martin, 10̄, MNHN. - Castro, 2013: 439, Leven Bank, between Glorieuses/Madagascar, coll. Miriky 2009, st. CP 3210, 29.06.2009, 1244'S, 48 12’'E, 442$491 \mathrm{~m}$ - IWP, Mozambique to French Polynesia; 5-491m.

Quadrella maculosa Alcock, 1898

Sakaija africana (Griffin and Tranter, 1986) - Ng and Richer de Forges, 2015: 170, Leven Bank, between Glorieuses and Madagascar MIRIKY 2009, several stations north of latitude $13^{\circ} \mathrm{S}$ and longitude around $47-48^{\circ} \mathrm{E}$ - WIO, Leven Bank, northeast Madagascar to South Africa; $122-319 \mathrm{~m}$.

Schizophrys aspera (H. Milne Edwards, 1834)

Scylla serrata (Forskål, 1775)

Sesarma ortmanni (Crosnier, 1965)

Sesarmops impressus (H. Milne Edwards, 1837) 
Sphenomerides trapezioides (Wood-Mason in Wood-Mason and Alcock, 1891) - Castro, 2013: 439, Leven Bank, between Glorieuses/Madagascar, coll. Miriky 2009, st. DW 3179, 26.06.2009, 1259'S, 480’ㄹ, 220-362 m - IWP, Madagascar to Indonesia; 136-528m.

Stebbingdromia plumosa (Lewinsohn, 1984)

Tanaoa pustulosus (Wood-Mason, in Wood-Mason and Alcock,1891) — Galil, 2003: 404, Geyser Bank, coll. 'filets Faubert', 11 April 1977, st. 114, 12²2,3'S, 46²8,2E, 300-600m, MNHN B19044; Mayotte, coll. 'filets Faubert', 29 March 1977, st. 61, 1246,0'S, 4458'E, 475-510 m (nb J. Poupin, these specimens are from BENTHEDI Expedition, although not specified in the study) - IWP, Somalia, Mayotte to Japan, Fiji; 85-977m.

Tetralia ?nigrolineata Serène and Pham, 1957

Tetralia cinctipes Paul'son, 1875

Tetralia glaberrima (Herbst, 1790) s.1.

Tetralia rubridactyla Garth, 1971 s.l.

Tetraloides nigrifrons (Dana, 1852) - Tetralia heterodactyla fusca - Serène, 1984: 283, Glorieuses, intertidal, coll. A. Crosnier September 1958, $3 \hat{\jmath} \widehat{\jmath}$ largest $7.5 \times 7.8 \mathrm{~mm}, 3$ 우 largest $7.6 \times 8.6 \mathrm{~mm}$, MNHN-B 8204. - Tetralia heterodactyla lissodactyla - Serène, 1984: 283, Glorieuses, intertidal, coll. A. Crosnier September 1958, 1ðึ 8.0×8.0 mm, MNHN-B8184. - Tetraloides nigrifrons - Castro, 1997: 72, Glorieuses, re-determination of Serène (1984) lots MNHN B8204, MNHN 8184, not Tetralia heterodactyla Heller, 1861 - IWP, Somalia, Mozambique, South Africa to Johnston Atoll, French Polynesia; intertidal, subtidal to $20 \mathrm{~m}$.

Thalamita ?mitsiensis Crosnier, 1962

Thalamita admete (Herbst, 1803)

Thalamita bouvieri Nobili, 1906 - Crosnier, 1962: 119, Mayotte. - Guinot, 1967b: 256, list with Mayotte - IWP, Tanzania, Mozambique to Japan, French Polynesia; subtidal to $85 \mathrm{~m}$.

Thalamita cooperi Borradaile, 1902 - Crosnier and Thomassin, 1975: 1112, Glorieuses, C. Jouannic coll. January 1973, dredge about 10m, $1 \delta^{\Uparrow} 7.0 \times 10.9 \mathrm{~mm}, 1$ ㅇ $5.2 \times 8.4 \mathrm{~mm}, \mathrm{MNHN}$ - IWP, Kenya, Glorieuses to Japan, French Polynesia; subtidal to $11 \mathrm{~m}$.

Thalamita crenata Rüppell, 1830 (Now in the genus Thranita, see Evans, 2018)

Thalamita gatavakensis Nobili, 1906

Thalamita gloriensis Crosnier, 1962: 98, Glorieuses, intertidal, coral sand, MNHN. - Guinot, 1967b: 257, list with Glorieuses. - Poupin et al., 2013c: 11, Glorieuses, list - IWP, Tanzania, Glorieuses to Hawaii, French Polynesia, invasive in Mediterranean ( $c f$. Galil et al., 2018); intertidal, subtidal REMARKS - Recently reported in the Mozambique Channel at Juan de Nova (Poupin, 2016) with specimens in MNHN (19 ov. 4.4×5.9 mm, st. 15, MNHN-IU-2013-16095; 3 juv., st. 12 , MNHN-IU2013-16096).

Thalamita gracilipes (A. Milne-Edwards, 1873) - Thalamonyx gracilipes - Crosnier, 1962: 91, Mayotte. - Guinot, 1967b: 257, list with Mayotte - IWP, Mayotte, Madagascar to Hawaii, French Polynesia; subtidal to 78m. - REMARKS - Now in genus Thalamonyx (see Evans, 2018).

Thalamita helleri Hoffmann, 1874 (Now in the genus Thranita, see Evans, 2018)

Thalamita integra Dana, 1852

Thalamita picta Stimpson, 1858

Thalamita prymna (Herbst, 1803) (Now in the genus Thranita, see Evans, 2018)

Thalamita pseudospinifera Crosnier, 1975: 715, Glorieuses, dredge 30m, January 1973, C. Jouannic

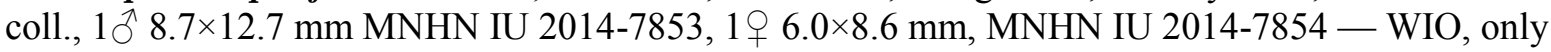
Glorieuses, $30 \mathrm{~m}$ - REMARKS - It seems that this species has never been reported since its description. In GBIF (2018) Internet dataset, however, there is a georeferenced record (SMF collections) of T. pseudospinifera from Japan (determiner not indicated but perhaps M. Türkay or K. 
Sakai) indicating that this species has perhaps a large IWP distribution. Photographs of the type specimens are available in MNHN-Collection (2018).

Thalamita quadrilobata Miers, 1884

Thalamita sexlobata Miers, 1886 - Crosnier, 1962: 117, Mayotte. - Guinot, 1967b: 256, list with Mayotte - IWP, Red Sea, Mayotte, Madagascar to Hawaii, Tonga; subtidal, 5-146m.

Thalamita sima H. Milne Edwards, 1834 - Miers, 1884: 530, Glorieuses - IWP, Mozambique, South Africa to Hawaii, New Caledonia; intertidal to $50 \mathrm{~m}$; records from Red Sea, Gulf of Aden and Arabian Sea are doubtful according to Apel and Spiridonov (1988).

Thalamita spinifera Borradaile, 1902

Thalamita stephensoni Crosnier, 1962

Thalamitoides quadridens A. Milne-Edwards, 1869

Thalassograpsus harpax (Hilgendorf, 1892)

Thyrolambrus efflorescens (Alcock, 1895)

Trapezia bidentata (Forskål, 1775)

Trapezia cymodoce (Herbst, 1801)

Trapezia digitalis Latreille, 1828

Trapezia formosa Smith, 1869

Trapezia guttata Rüppell, 1830

Trapezia lutea Castro, 1997

Trapezia richtersi Galil and Lewinsohn, 1983

Trapezia rufopunctata (Herbst, 1799)

Trapezia tigrina Eydoux and Souleyet, 1842

Tubuca urvillei (H. Milne Edwards, 1852)

Tumidodromia dormia (Linnaeus, 1763)

Tweedieia laysani (Rathbun, 1906)

Tylocarcinus styx (Herbst, 1803)

Urnalana elata (A. Milne-Edwards, 1873)

Urnalana pulchella (Bell, 1855) - Galil, 2005: 29, Mayotte, lagoon 46m, coll. A. Crosnier August

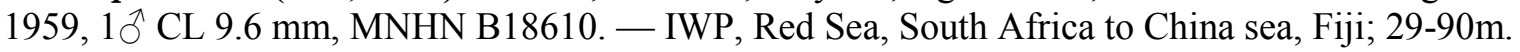

Varuna litterata (Fabricius, 1798)

Venitus latreillei (Desmarest, 1822) - Macrophthalmus latreillei - Crosnier, 1965: 131, Mayotte, mud grounds with adults between 5-15 m and young to 50m. - Guinot, 1967b: 282, list with Comoros. Venitus latreillei - Bouchard et al., 2013: 38, Mayotte, list from previous records - IWP, Red Sea, South Africa to Japan, New Caledonia; sediments in shallow subtidal to $50 \mathrm{~m}$.

Xanthias cherbonnieri Guinot, 1964

Xanthias glabrous Edmonson, 1951 - Guinot, 1964b: 6, 28, 32, Mayotte, coll. A. Crosnier, 1 đิ 5×8 mm, MNHN. - Guinot, 1967b: 269, list with Mayotte. - Serène, 1984: 193, Mayotte, $1 ð 5 \times 8$ mm, MNHN) - IWP, it seems that this species is still known only from Mayotte and Hawaii (see Castro, 2011); subtidal, 12-91m.

Xanthias lamarckii (H. Milne Edwards, 1834)

Xanthias maculatus Sakai, 1961 s.1.

Xenocarcinus conicus (A. Milne-Edwards, 1865)

Zosimus aeneus (Linnaeus, 1758)

Zozymodes cavipes (Dana, 1852) 